


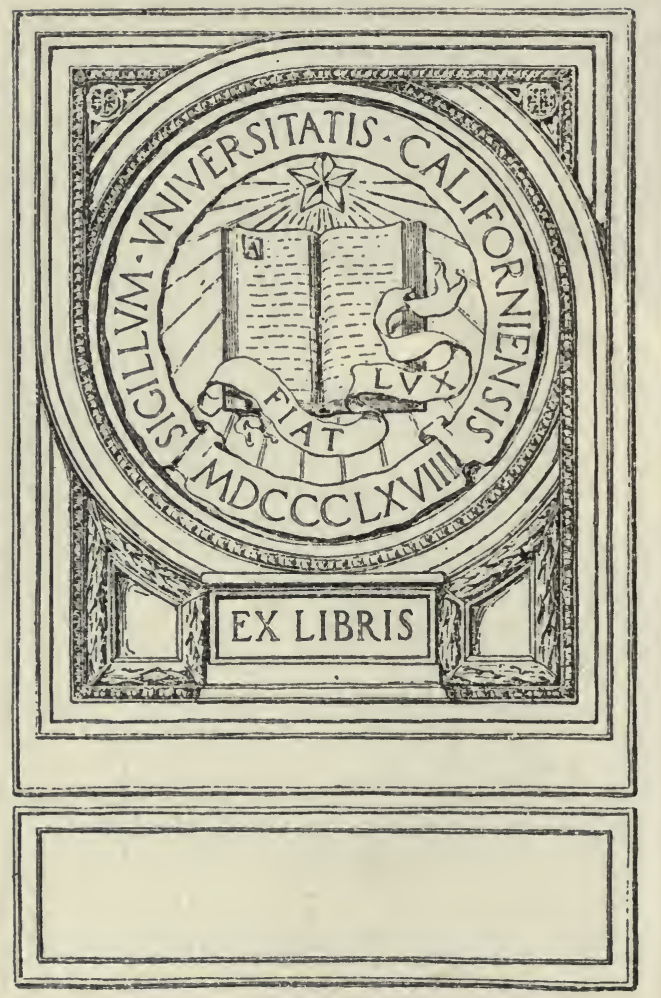


. 


\section{Digitized by the Internet Archive}

in 2007 with funding from Microsoft Corporation 
FIFTY YEARS OF A SHOWMAN'S LIFE 
Br THE SAME AUTHOR.

IN THE DAYS OF VICTORIA. Illustrated. EDMUND RACK, THE Society HE FOUNDED AND THE CoMpany he KEPT.

Eтc. 
-

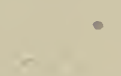




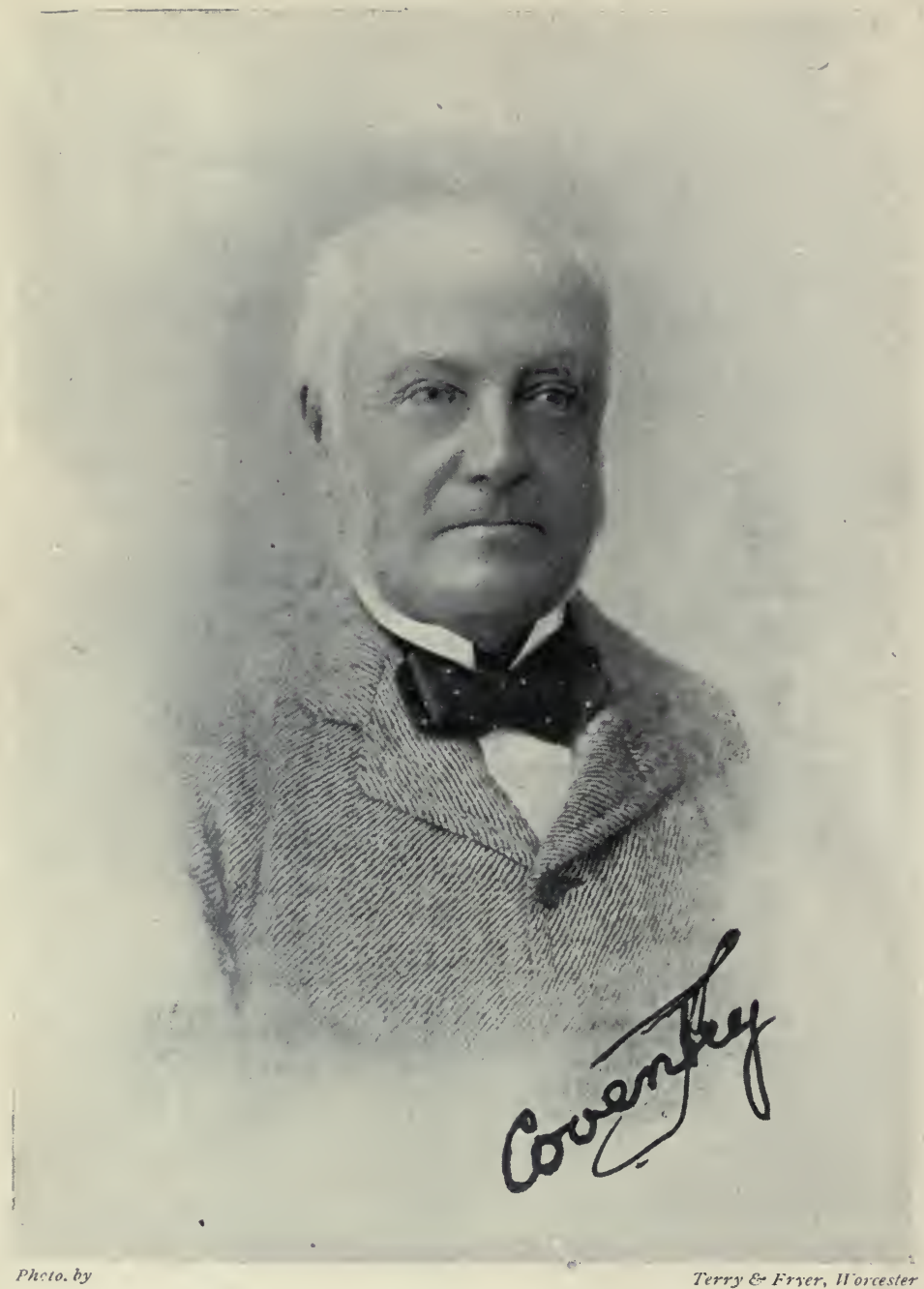

THE EARL OF COYENTRY, PRESIDENT OF 3 HE BATH AND WEST ANI) SOUTHERN COUNTIES SOCIETY IN IS8O AND AGAIN FROM 1914 TO PRESENT TIME. 


\section{FIFTY YEARS OF A \\ SHOWMAN'S LIFE}

\section{BY THOMAS F. PLOWMAN}

SECRETARY AND EDITOR OF THE BATH AND WEST AND SOUTHERN COUNTIES SOCIETY

LONDON : JOHN LANE, THE BODLEY HEAD. NEW YORK : JOHN LANE COMPANY MCMXIX 

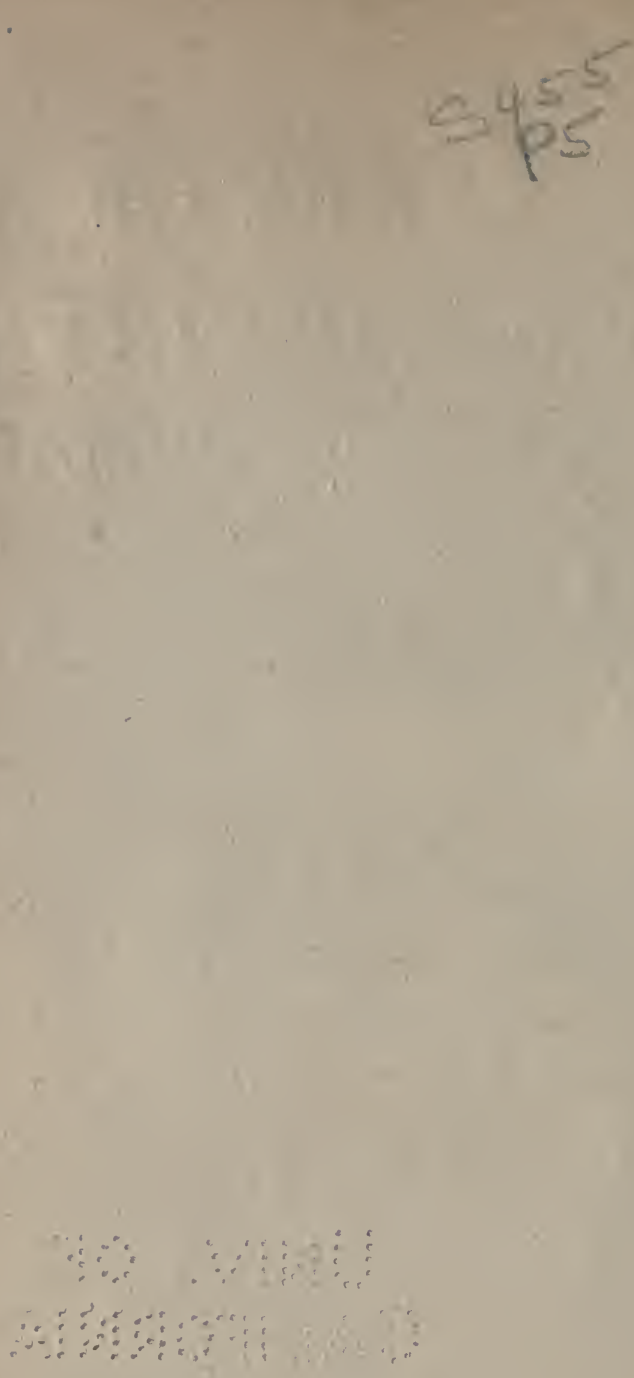

WILLIAM CLOWES AND SONS, LIKITED, LONDOX AND BECCLES, ENGLAND. 
TO THE

\section{PRESIDENT AND COUNCIL}

OF THE

BATH AND WEST AND SOUTHERN COUNTIES SOCIETY

IN GRATEFUL REMEMBRANOE

OF A LONG AND BAPPY ASSOCIATION

I DEDICATE THESE CHAPTERS

OF A SHOWMAN'S LIFE 



\section{CONTENTS}

\section{CHAPTER I}

A Showman's Jubilee-The Manner and Method of these Recollections - The Old Agriculturist-Early Farming Associations .

\section{CHAPTER II}

A Good Old Sport-w"Lawyer" H.-An Heir-Apparent Im. pounded

\section{CHAPTER III}

Why I became a Showman-The Sword of Damocles-The Oxfordshire Agricultural Society-An Early Mission-The Canny Scot . . . . . . . . . . 21

\section{CHAPTER IV}

The Discovery of the Key of Success-Political Strategy-The Assistant Secretary-The Working of the Spell . . . 38

\section{CHAPTER V}

A Bit of Sport-The Question of Supplementary Attractions-A

Practical Committee-The Future of Shows . . .

\section{CHAPTER VI}

The Festive Side of Agriculture-Carving Simplified-Speech and Song-Lemonade and Gin . . . . . . 51

\section{CHAPTER VII}

"A Fine Old English Gentleman"-A Pelitical Meteor-A Surprise Visit 


\section{CHAPTER VIII}

"As Merry as a Whitsan Morris Dance"-The Butleigh Revel - "Stop Thief"-The Story of a Watch . . . .

\section{CHAPTER IX}

A Clouded Horizon - Farmers' Trials - The Revolt of the

Labourers-The Maligned Landowner. . . . .

\section{CHAPTER X}

The Royal Agricultural Society-The Shorthorn Boom-John

- Thornton-The Bath and West Society-A Kindly Sendkoff

\section{CHAPTER XI}

My New Sphere of Work-Next Door to a Tragedy-Signs and

Omens-A Chamber of Horrors . . . . . . 105

\section{CHAPTER XII}

A Progressive Society-Dairy Education-The Old Board of Agriculture - Travelling Missioners - The Mischievous Microbe. • . . . . . . . . .

\section{CHAPTER XIII}

The Divining Rod-John Mullins-Divining Methods-Conclu. sions arrived at-Letter from a "Dowser" . . . .

\section{CHAPTER XIV}

A Devon Squire-A Somerset Squire-A Kentish Squire .

\section{CHAPTER XV}

Cider Making at Home and Abroad-A Voyage of DiscoveryThe National Fruit and Cider Institute . . . .

\section{CHAPTER XVI}

A Show Yard Idyll-The Sunday Service-The Power of Human Sympathy-The Y.M.C.A. in the Show Yard . . . 168

\section{CHAPTER XVII}

"Gee-up, Dobbin"-Topics of Yesterday and To-day-Coke of Worfolk-Hands Across the Sea-Benjamin Franklin-An Ristoric Letter 


\section{CHAPTER XVIII}

Some Distinctive Personalities-Lord Redesdale - " Honest Lord Althorp "- "The Colonel"-Lord Tredegar-A Trio of

Workers . . • . . . . . • . 189

CHAPTER XIX

Foyalty in the Show Yard-The Late King Edward-Some

Equine Irreconcilables-The Area of Responsibility-The

Present King-An Accomplished Pony and an Enterprising

Waiter . . . . . . . . . .

CHAPTER XX

An Archdeacon on Cheese-And on the Trinity-George Gibbons

- "Where the best Princesses come from"-The Song of

the Cheese . . . . . . . . . .

\section{CHAPTER XXI}

A Wonderful Woman-A Valued, Friendship-A Royal Recog. nition

\section{CHAPTER XXII}

Some Show Yard Incidents-The Lord and the Muck CartHorse Shoeing-Liveried Splendour-A Watchful Goose-

A Missing Picture.

\section{CHAPTER XXIII}

Some Echoes of the Past-A Surprise Packet-Apple Grafting

-How the Secretary was elected in old time . . . 253

\section{CHAPTER XXIV}

A Showman's Letter-bag-Some Epistolary Singularities . .

\section{CHAPTER XXV}

Cloud and Sunshine-Some Show Yard Trials-The Kilburn Slough-The Smithfield Fog-A Cornish Gale-The B.\& W. Mess-Relics of the Past

\section{CHAPTER XXVI}

Some Personal Heppenings-A Double-Barrelled Official-A Vanishing Secretary-A Happy Incident-A Halt on Life's Highw\&y 


\section{GONTENTS}

\section{CHAPTER XXVII}

How I swore Fealty to Two Corporations-How Bath belped Oxford-The Juvenility of Oxford compared with Bath . 293

\section{CHAPTER XXVIII}

The Show in War-Time-Administrative Difficulties-A Concertina and a bit o' baccy-Aid for our Allies . . . 304

\section{CHAPTER XXIX}

Arcadia-" A Shattered Day-Dream " . . . . . . 316

CHAPTER XXX

Some Retrospects-A Sad Feature of Long Service-Direction

Posts-Parting Words . . . . . . . 320

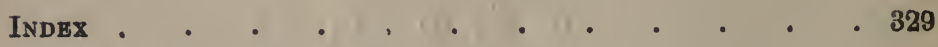




\section{LIST OF ILLUSTRATIONS}

FACING PAGE

The Earl of Coventry, President of the Bath and West and Sodthern Counties Society in 1880 and again FROM 1914 TO PRESENT TIME. . . . Frontispiece

The Young Showman on the Threshold of Responsibility .

The late King Edward VII., Quegn Alexandra, and the

Earl of Clarendon (President) in the St. Albans

SHOW YARD IN 1896 . $\quad$ • . . . . . 210

Grodp of Stewards of The Exeter Show IN 1899 • 242

The Old White Hart Inn, Bath, where the Society's

FIRST DINNER WAS HELD • . • . • • . 276

Inauguration of the Bath Show in 1912 by the Showman-

Mayor, accompanied by the Mayoress and the Lord

Mayor of Bristol (Sir Frank Wills) . . • . 286

The Inadguration of the Truro Show IN 1913 • • . 286

The Inadguration of the Bath Show (1912) • • • • 296

The Old Showman, Grown Grey IN The Service • • • 322 



\section{FIFTY YEARS OF A SHOWMAN'S LIFE}





\section{FIFTY YEARS OF A SHOWMAN'S LIFE}

\section{CHAPTER I}

A Showman's Jubilee-The Manner and Method of these Rooollections

-The Old Agriculturist-Early Farming Associations.

"Life is a leaf of paper white,

Whereon each one of us may write

His word or two-then comes the night."

$\mathrm{N}$

OT long since I unburdened myself of a series of reminiscences, under the title In the Days of Victoria, in which I endeavoured to portray, by the light of personal experience, the ebb and flow of life in a city, its swish and swirl, its toils and its pleasures, during the eventful Early and Mid-Period of the late Queen's reign. I had to leave the country-side severely alone, or my story would have run to too great a length. But the kindly reception my town recollections met with has encouraged me to supplement them with a companion-series dealing with my long association with agriculture and its representatives. A jubilee is usually a time for retrospections, and, as my career as an agricultural showman dates from the year 1867, I am only following precedent in regarding a fifty years' anniversary as an occasion for harking back upon the past. 


\section{FEFTY YAAPS OF A SHOWMAN'S LIFE}

The ordinary showman-Barnum and Lord George Sanger to wit-has amused and enlightened the outside world by a recital of his experiences in pursuit of his vocation, and has, metaphorically, taken behind the scenes of his profession all who cared to go there. But this example, so far as I know, has not been followed, at any rate with corresponding particularity, by any agricultural showman other than myself.

My endeavour will be to depict from personal observation the inner life of the agricultural show yard and the manners and customs of its inhabitants, including those responsible for its control; and to point some contrasts between yesterday and to-day in agricultural methods and in the characteristics of those who pursue them. I purpose casting my retrospective net sufficiently wide to embrace within its meshes any matters, whether inside or outside the show yard, which naturally arise out of my agricultural experiences.

Let me forestall criticism by saying that I propose to indulge in many trivialities, to put on record incidents that are quite unimportant in themselves, but which may serve to illustrate the doings of the little world in which I have moved. To form an adequate idea of any particular phase of life, we must take cognizance of those minor details of which it is largely made up and which throw so much light upon the underlying motives that are the springs of action.

So in the telling of my story I do not propose to ransack my memory for recollections of incidents of great pith and moment, for these are to be found in newspapers and formal records. My 
old memories are far removed from "official utterances," with which they have no affinity, though I may, perhaps, remark, with some knowledge of officialdom, that it does not follow that they are the less reliable on that account. Official communications take life very seriously, and rarely lift the veil which conceals the world behind the scenes from the gaze of ordinary mortals ; whereas reminiscences, if they are good for anything, generally do, and herein lies the main distinction between the two.

When I first came into direct contact with agriculture and its exponents there was a much wider gulf between town and country than there is at the present time. But a deal of water has flowed under the bridge since the days when the townsman, so long as he had cheap bread and as much of it as he could both consume and waste, knew little, and cared less about, how and whence it came. Agriculture was mostly outside his purview, except as a medium for hostile criticism of landowners and farmers. But, even previous to the war, there was a growing manifestation of interest in the greatest of national industries, and now that the ordinary citizen has had it forcibly brought home to him that our very existence is bound up in the prosperity of agriculture he is making himself much better acquainted with the conditions under which it is carried on.

That the "old order changeth, yielding place to new," is as true of agriculture as of most other mundane matters, and it is doubtful whether, during any period of history, this has been more distinctly emphasized than it has been within 


\section{FIFTY YEARS OF A SHOWMAN'S LIFE}

the last fifty years. In looking back through this vista of time, one can see, by contrast, the impress left by the great changes of the nineteenth century upon the individual character of the British farmer especially. The development of railways, steamships and telegraphs; the increased adaptation of machinery to farming operations ; the application of scientific principles to the cultivation of the land-all these factors have tended to obliterate distinct types of character among farmers, as well as among representatives of other callings, in favour of uniformity. No doubt this has been a gain in some respects, inasmuch as it has resulted in a greater consistency and reasonableness of disposition, and in the formation of a broader outlook with respect to the affairs of life. The farmer, nowadays, being a better-read and a more-travelled man, is more competent to hold his own in the world at large, and is regarded in a much less degree as the embodiment of a distinct class, with manners, customs and traditions of its own, and having little affinity with those of the workers in cities and towns. At the same time, we have lost something in picturesqueness, and in those phases of character, born of the soil and fostered by the comparative isolation of living, which was the lot of the agriculturist under the old condition of things. In him the novelist and dramatist found materials ready to hand, and requiring but little touching up for their pictures of the country-side. The farmer was invariably drawn by the writers of those days as a combination of breezy heartiness, dogged obduracy, and rooted antipathy to change, who always gave 


\section{THE BRITISH FARMER IN FICTION}

expression to his sentiments in a voice as far removed as possible from a whisper, and in a dialect redolent of the country-side, whilst a big stick gave force and emphasis to his observations.

These characteristics were admirably depicted in the novels of Smollett and Fielding, and in later times in those of Dickens and his contemporaries. He figured during the early period in such popular pieces as Colman's "John Bull" and Morton's "Speed the Plough." I have before me the play-bill of a performance on December $8 \mathrm{th}$, 1840, at the Bath Theatre, under the patronage of "The Most Noble the Marquis of Lansdowne and the Bath and West of England Agricultural Society," in which the pièce de résistance was "Speed the Plough." It would be interesting to read the verdict of present-day critics if such a piece were put upon the stage now as a picture of present agricultural life and character, and we can imagine how consumedly the audience would laugh at its apparent improbability. And yet our fathers took it all seriously. Farmers then lived by farming, pure and simple, and neither had occasion nor cared to supplement their means of livelihood by taking paying-guests in the summer season, or by turning their fields, when they abutted upon a line of railway, into advertising stations for patent medicines or cheap upholstery.

It must be admitted that a multiplication of travelling facilities has done much to bring country and town into closer contact, and to promote a better understanding one of the other. Mr. Jorrocks, it will be remembered, said : "A Cockney looks upon a farmer as an inferior crittur-a sort 


\section{FIFTY YEARS OF A SHOWMAN'S LIFE}

o' domestic conwict, transported far beyond the bills o' mortality, and condemned to wander in 'eavy 'obnailed shoes amid eternal hacres o' dirt and dandylions." If there had been a Mr. Jorrocks on the other side, he would, no doubt, have given expression to an equally unflattering description of the farmer's opinion of the Cockney. Happily, these estimates, based on fiction, have since given place to others more consonant with fact.

Oxford, where I was born and bred, being a good hunting-centre, within easy reach of the South Oxfordshire and Old Berkshire Hounds, some of my early hob-nobbings with farmers were due to the chase, for as a boy I used to enjoy going with a kindred spirit after the hounds when I had the chance, though, of course, I had to rely upon Shanks's mare for a mount, being only a "toddler." When a bit leg-tired, we were sometimes lucky enough to drop across a good-natured farmer, with whom we had a nodding acquaintance, and he would invite us to "come in and tell the missus all about the run," which meant a cut off the joint and nothing to pay. In the days when agriculture was more prosperous than it is now, there was a good sprinkling of farmers at every meet, who, well-mounted, could hold their own over a stiff bit of country. Since then, alas, times have altered, and even before the war, the fields were much impoverished.

I early realized the special purpose for which foxes were created, and the beneficence of the arrangement which distributed them in those quarters of the globe where sportsmen flourish and abound. I had likewise a keen appreciation 


\section{SAINTS' DAYS}

of the kindly forethought and consideration of the Early Fathers or the Early Christians-whichever it was-who instituted the observance of saints' days, inasmuch as we had a whole holiday on these occasions. I may say that at this time $I$ was trying the patience of certain pastors and masters at the Cathedral School on Wolsey's foundation at Christ Church. I will not go so far as to assert that these respites from our classical studies were originally designed to afford us an opportunity of gratifying a taste for sport; but this I do know, that the hunting appointments were eagerly scanned by some of us when saints' days were imminent. It might possibly, though it is a moot point, have been more to the good of our spiritual health if we had devoted such opportunities, as, perhaps, it was intended we should, to the quiet contemplation of saintly virtues in strict seclusion; but I am quite sure this would not have been of the same physical benefit to us as were those trudges over hill and dale which we took amid the fresh air of the country. After a good spin, with what cheerful appetites we disposed of bread and cheese, washed down with shandy-gaff, at the Bear at Cumner, the Royal Oak at Stow-wood, or some other equally wellknown hunting house-of-call !

When on sport intent, three or four of us usually kept together. In the company to which I attached myself, one member in particular-a lean, lanky individual named Linwood-stands out distinct in memory from the rest. In school he was a nobody, and nothing he ever said or did there was considered to be of the slightest importance. 


\section{FIFTY YEARS OF A SHOWMAN'S LIFE}

But out of school he was looked up to as the repository of as much legal wisdom as we could ever associate with any fellow-mortal wearing turn-down collars and a short jacket. He certainly had a knowledge of the world, which occasionally stood him in good stead when he got into scrapes on saints'-day excursions, but his chief claim to distinction was his legal erudition. His profundity in this particular line was, as he gave us to understand, mainly due to the fact that his father sat on the Borough Bench; hence the son drew his supplies of legal lore direct from the very fountain of justice itself. He it was-the son, not the father-from whom we derived the belief that, in the eye of the law, shooting a fox was only one degree less heinous than shooting a man. Once, during a paper-chase, when we were in full cry, the two hares came flying back into our midst with the tidings that a dog, who objected to their laying the scent across his master's kitchen garden, had not only insisted upon their returning post-haste the way they came, but, to ensure despatch, had, with the help of a good set of teeth, put special pressure upon the fleshy part of the leg of one of the hares. Linwood had the law of dog-bites at his finger-ends, and knew exactly the proper course to pursue. "Every dog," he explained, "has his day," i.e., was entitled to one good bite. "The law allows it and the court awards it" : it was his right, his due, and no one could legally deprive him of it. But once let a dog so far forget himself as to indulge in a second nip, his doom was sealed. Hence, he pointed out, it behoved the bitten one to return with all speed 


\section{CONTEMPT OF COURT}

and beguile the animal into further impressing his views upon his person. This course commended itself to all of us, except the hare, who, to our disgust, did not take sufficiently kindly to the idea to act upon it, and so the soundness of the advice was never brought to test in a court of law.

"Contempt of court," of which the unen-" lightened of us had very hazy notions, was on one occasion the theme of his discourse, and this is how he brought home to our minds in what it consisted. "Supposing you wish to show your contempt for the law, you just put your finger up to your nose at a p'liceman, who collars you and brings you before a judge. Then the judge shows his contempt for you by ordering you to be birched-and that's contempt of court." All which we steadfastly believed. Verily, "a little knowledge is a dangerous thing," sometimes! I may add that Linwood never justified our anticipations by becoming Lord Chief Justice, or even a K.C. As a matter of fact, he adopted journalism as a career, and did well at it. 


\section{CHAPTER II}

A Good Old Sport-" Lawyer" H.-An Heir-Apparent Impounded.

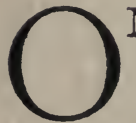

$\mathrm{NE}$ of my older acquaintances of those days was Joseph Harris, of Woodperry, a fine specimen of the old type of yeomanfarmer, and known throughout the country-side as " one of the real old-fashioned sort." Hale and hearty, with a cheerful countenance, ruddy with the hue of health, and set off by hair of silvery whiteness, he was redolent of the country in look, speech, and everything else. He was an enthusiastic fox-hunter, and in his younger days kept up with the best, but when I knew him he admitted he felt a bit too old and stiff to do more than a gentle toddle after hounds afoot. However, horse, hound and fox were alike welcome on his land at all times. He had a wonderful reputation for the brewing of ale, which was thought to rival even the audit liquor of Brasenose and Magdalen. Many a sportsman has had a taste of it, and gone on his way afterwards "like a giant refreshed," for Joseph, being given to hospitality, did not keep his good things to himself, whether they were stories of hunting exploits, of which he had a rare assortment, or the cup that cheers.

I told the following story in an article I contributed some years ago to Baily's Magazine of Sports 


\section{A ROYAL DRINK}

and Pastimes, and I am indebted to the publishers of the latter for their courtesy in permitting its repetition here.

The fame of the old sportsman reached the ears of the late King, then Prince of Wales, when he was an undergraduate at Oxford, and one day, when out with the South Oxfordshire, his Royal Highness, knowing that Joseph would appreciate it, good-naturedly determined to give him a call and taste his ale. The old man was in a fine flutter when he found who had pulled up at his door for a drink. In double-quick time, and a high state of excitement, he was outside with a jug of foaming ale in one hand and a horn in the other. Advancing to his Royal Highness, who was mounted, Harris, with a beaming face, was just about to fill up the horn and hand it up to his distinguished guest, when a sudden look of horror came into his eyes, and he stood transfixed, as though he had made some terrible discovery. And so he had, for the awful truth had flashed across him that, in his bustle and excitement, he had clean forgotten to remove his head-gear. Truly, he was in a dilemma, for, with both his hands full, how could he uncover himself, and yet he felt he daren't stand there in the presence of Royalty as he was!

Happily, nature came to the rescue by unloosing his tongue, and setting free what was on the tip of it, though without giving him time to choose his words. Hence his pent-up feelings found expression in the agonized appeal: "For God's sake, somebody take my hat off!"

This was too much for either Prince or people 


\section{FIFTY YEARS OF A SHOWMAN'S LIFE}

to bear with equanimity, and soon was "laughter holding both its sides" all round. The HeirApparent, with the courteous and ready tact which, many a time and oft since then, had helped to smooth over a difficulty, put an end to the old man's perplexity by requesting him, as a personal favour, to keep his hat on out of doors. Then his Royal Highness praised the ale, and expressed his thanks in a way that left Joseph in the seventh heaven of delight, and, as an old country-side expression has it, "as proud as a dog with two tails."

There is a sequel, and a very pretty one, to this story, for shortly after the episode in question Joseph received from his Royal visitor, as a memento of the occasion, two drinking horns, handsomely mounted in silver, accompanied by a kind message.

Not long afterwards I had the pleasure of sampling the ale that the Prince so appreciated out of one of these particular horns, and of hearing from Joseph himself the story of his absentmindedness, so I can go bail for the accuracy of what I have narrated.

Harris not only knew every inch of the country round about him, but appeared to us boys to have a personal acquaintance with every fox in the neighbourhood, for he would often predict with remarkable accuracy the line Reynard would take when hounds were after him. I remember, on one particular occasion, when some of us had seen the hounds throw off, he remarked that he knew enough of the fox they were after to make a pretty good guess as to what he would do, and 


\section{THE OLD STAGER}

that, if we followed him he thought he could show us some of the fun. Needless to say, we asseverated our desire to stick to him as tight as wax. Forthwith he walked us clean away from huntsmen and hounds and across several fields to a little knoll, where, putting us behind a group of trees, he told us to keep a sharp look-out. After a bit we saw "the old stager," as Harris described him, coming across the fields, and making straight for us. "Don't breathe, lads," whispered Harris, "till he's by." It was a thrilling moment as he came up the rise, and, looking neither to the right hand nor to the left, but intent only upon how he could best save his brush, passed within a few yards of us. Never before had I been so close to a fox, and I shall never forget the sensation.

Then out pops Harris, and, says he, "Now, lads, a good 'un" ; and, led by the old veteran, we gave a view-halloo that was enough, like John Peel's, to "waken the dead." This brought up horse and hound, and soon we were enjoying the ever-delightful spectacle of a field in full cry. We followed as fast as our young legs would carry us, but Harris took one of his short cuts, and saw more than we did. The hounds, ere they came up with our particular fox, got on the scent of another, and Harris, with his usual intuition of what was going to happen, settled in his own mind that our Reynard would make for a certain spinney, so he posted himself on the line of route, and had the satisfaction of seeing Master Fox quietly sneaking towards "home, sweet home," 'neath the shelter of a friendly hedgerow.

Harris gave us a very hospitable send-off ere 


\section{FIFTY YEARS OF A SHOWMAN'S LIFE}

we parted, and added to our delight by presenting us with a souvenir of the occasion in the shape of a fine brush, a trophy of his younger days.

Whether it was due to the exhilaration of the chase, the effects of the home-brewed, or a combination of the two, I am not at this distance of time prepared to say, but I remember we were in a high state of jubilation as we started on the return journey. A friendly poultryman, with whom we scraped acquaintance, gave us a lift homewards, and the three of us who were his passengers stowed ourselves away in pretty close quarters among the straw at the back of his market cart. Here, during our progress, we took it in turns to triumphantly wave the brush, so that it might be "plain for all men to see," with a view to creating an impression that we had been in at the death, and received the reward of our prowess. To emphasize the fact further, every flourish of our trophy was accompanied by a "tally ho, gone away," which made the welkin ring as long as we were in the country, and shocked "the High" out of all propriety when we emerged into it from Magdalen Bridge.

Joseph Harris has long since departed for those other "happy hunting-grounds," whence there is no return, but his memory seemed to be worth perpetuating in these rambling recollections, if only as illustrating an agricultural type which has mostly passed out of existence.

Then, as now, there were farmers and farmers, and one of a distinctly different type to the last came sufficiently within my sphere of observation to enable me to include him in my sketchbook of 
memories. "Lawyer" H. was a farmer pure and simple, but, by his extraordinary fondness for litigation, and for conducting his cases himself, he deservedly earned the prefix universally accorded to him. Probably the fact that he usually acted as his own attorney and counsel, accounted for the frequency with which he was non-suited.

When, as boys, "a-hunting we would go," we knew sufficiently about the penalties attaching to trespassing to be induced to steer very clear of H.'s land, for trespassers, particularly fox-hunters, were his special abhorrence, and, as will shortly be seen, he knew no distinction of persons.

One day, some undergraduates, riding over his land, were promptly warned off. They took the hint and turned round, but also took the liberty to indulge in a canter over another bit of proscribed domain before finally departing. $H$., who had kept his eye upon their movements, thereupon mustered his farm-hands and waylaid the offenders as they turned into the high road, with intent to secure one of them as a hostage. After leaving the forbidden land, the trespassers had been joined by other horsemen returning from the hunt, and these united with the defending party in their resistance to capture. A desperate fight ensued, which resulted in an undergraduate being dragged away as a prisoner to the farmer's house. Here he was forcibly detained for a considerable time, being only released upon giving a pledge that he would appear to answer for his doings in the Vice-Chancellor's Court. He duly fulfilled his undertaking, but not exactly as had been anticipated by his captor, for he summoned the latter, 


\section{FIFTY YEARS OF A SHOWMAN'S LIFE}

and also one of his servants for assault and jllegal detention. During the hearing of the case, it transpired that "Lawyer" H. had, in the excitement of the battle, carried off, in error, one of the second party of horsemen, who had not been on the land in question at all. Hence, he had no case as to the trespass, whilst he was fined twenty shillings and costs for his own and ten shillings and costs for his servant's share in the assault and detention. One of the adjudicators was Dr. Marsham, Warden of Merton College, who, in view of the particularly good friend he always was to hunting, must have derived peculiar enjoyment from assisting to hoist the engineer with his own petard.

The memory of the contretemps which this attempt to take the law into his own hands resulted in rankled in the discomfited one's bosom, more especially on account of the unsympathetic merriment it everywhere gave rise to. Hence, he was for ever on the look-out for an opportunity to exact retribution. And this provided a dramatic sequel to the trespassing story.

One day, when the Prince of Wales was out with the South Oxfordshire hounds, and sport was not of the best, his Royal Highness, with one of his equerries, Colonel Keppel, and two or three undergraduate friends, took a ride across country, and, all unthinkingly, came on to "Lawyer" H.'s land, finishing up by riding into his farm-yard, with the intent to take a short cut through it. No sooner, however, had the horsemen got into the yard, than H., who was on the watch, had the gate at each end promptly closed and guarded 


\section{ROYALTY IMPOUNDED}

by a party of farm-hands, armed with pitchforks. Having issued instructions to his force to resist any attempt on the part of the entrapped ones to escape, he saluted the discomfited horsemen with "Now I've got 'ee!" Asked for an explanation, he announced that he claimed a pound for trespass, and gave all concerned to understand that they would remain where they were till it was forthcoming.

Some one hastened to impart the name of the illustrous personage whom he had impounded, the informant being under the impression that it was only necessary to mention this to ensure an instant release and a humble apology. But "Lawyer" H. was not built that way, and the only response he vouchsafed was: "Prince or no prince, I mean to have a sovereign before any of you go."

His Royal Highness, who was intensely amused when he grasped the situation, took the affront most good-humouredly. As it happened, not anticipating he would ever be called upon to pay ransom in a land over which he was predestined one day to rule, he had made no privision for such an emergency; and had not so much as a sovereign in his pocket. His friends, happily, were able to come to the rescue, and by satisfying the demand in full, secured the release of their future sovereign and themselves. Perchance, if, some centuries hence, the historical novel comes once more into fashion, the scene in the farmyard at Barton may furnish a striking incident for one of the chapters, and may serve to illustrate the revolutionary tendencies of the nineteenth century in England. 


\section{FIFTY YEARS OF A SHOWMAN'S LIFE}

"Lawyer" H. departed this life long since, but, in my mind's eye, I can still see his thickset figure and rugged, weather-beaten countenance, on which dogged determination - or, as some would describe it, unyielding obstinacy-was writ large. It was framed in by an antique form of head-gear, with lappets which came down over the ears, and were tied under his chin. He invariably had a thick stick in his hand and a faithful dog at his heels. He was entitled to be called "a character" of a type of which there can now be few, if any, survivals, in these more prosaic days, when the tendency is to put eccentricity at a discount. In fact, he seemed out of date even in the 'fifties and 'sixties, and gave one the impression of being a derelict from the remoter past, represented by novels of the Tom Jones type. 


\section{CHAPTER III}

Why I became a Showman-The Sword of Damocles-The Oxfordshire Agricultural Society-An Early Mission-The Canny Scot.

M

$\mathrm{Y}$ father, who enjoyed the confidence of landowners and farmers alike, held several appointments connected with agriculture, including the secretaryship of the Oxfordshire Agricultural Society. In view of my friendly relations with representatives of the farming interest, it might naturally be supposed that I should have looked forward to following in my father's footsteps. Yet I have to confess that, although in the end I took up his work, this was due much more to accident than inclination on my part. The fact was, as I have explained in my town reminiscences, I had, in my own mind, chosen my path in life long before I was out of my 'teens and my father had acquiesced in my choice. I was devoted to books, and on leaving school I obtained a position in the Bodleian Library. This I held for some years and until, just after I was of age, when I was elected to the chief librarianship of the Oxford City Public Library. I had contentedly settled down in this office, which, with certain kindred literary work, absorbed all my energies - at least, I thought it did-when in 1867 my father, to my great sorrow, was suddenly and fatally struck down, a victim to heart failure. 


\section{FIFTY YEARS OF A SHOWMAN'S LIFE}

I was then twenty-three years old, and, to save his appointments passing into other hands, I had to use my best endeavours to secure them. Mainly because I was my father's son, I was unanimously elected to the vacant offices, although I had little knowledge of the work they represented. So it was in fear and trembling, and with many misgivings, that I shouldered my burden. At the same time I wanted to hold on to my librarianship, as a stand-by, in case, as was only too probable, I came to grief in my new responsibilities. But I was in doubt as to how my committee would take this combination of duties. So I unbosomed myself to the chairman, one of the most kindly-hearted of men, and he said, "Hold on and say nothing, but take care not to give any of us a chance to say the city's interests are suffering thereby." I took his advice, and was never disturbed from start to finish, but it meant working double shifts.

Then followed the ever-present dread, which weighed on me like a nightmare, that my ignorance would infallibly betray itself to my own shame and discomfiture. I had undertaken to run an Agricultural Society with an annual show, to conduct a Corn Exchange, to administer various agricultural agencies, and, whenever required, to act as a sort of agricultural general-utility-manand all this without any previous education, except that of a most superficial character, to fit me for the position. My bibliographical knowledge, on which I had set such store, was nothing better than a drug in that market in which I now found myself. I will give an instance in connection with my first show of how profoundly ignorant I 


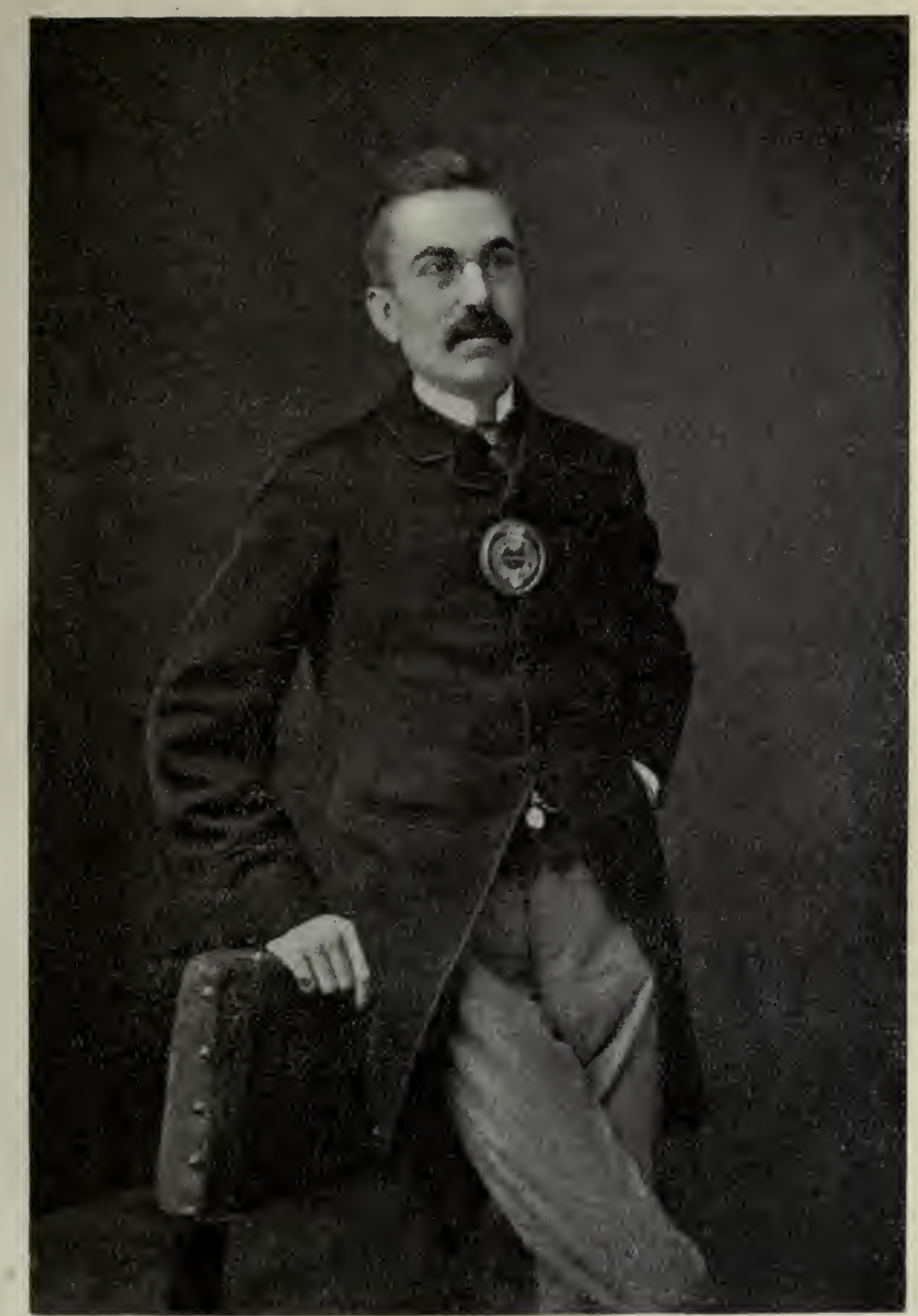

Photo. by

W. E. A. H. Fry, Brighton

THE YOUNG SHOWMAN ON THE THRESHOLI OF RESPONSIBIIITY. 



\section{MY PRISTINE IGNORANCE}

was of even the most elementary conditions applying to the work $\mathrm{I}$ had undertaken, and what risks I ran of bringing about some such catastrophe as I was always dreading. It was a law with agricultural societies at that time, and is with most of them still, that no judge must see a catalogue of the stock or produce upon which he has to adjudicate until after he has given in his awards, so that it might not be supposed that his decision was influenced by a knowledge of the name of an exhibitor, who might be a friend or neighbour. My long after-knowledge of agricultural judges has led me to the conclusion that, speaking generally, their integrity and honesty of purpose are a suf. ficient guarantee for the bona fide character of their decisions, but unsuccessful exhibitors do not always recognize this, and hence there is reason in withholding the catalogue specifying the exhibitors' names. At the same time, it may be safely asserted that if a judge does not intend to run straight there are more ways than one by which he can obtain the information in question. This is by the way, my point being to show the risks a showman as ill-informed as myself ran in discharging his functions.

The day before the show opened one of the stewards made some casual remark about the judges' books. In my innocence, I said that the printed catalogues would be all ready for the judges. In tones of horror, he told me that under no circumstances must they catch a glimpse of the printed catalogue before judging. This was an eye-opener to me, and then I found that it was part of a secretary's duty to provide manuscript 


\section{FIFT'Y YEARS OF A SHOWMAN'S LIFE}

books, giving such essential particulars as the age, sex, etc., of each animal, but omitting all mention of the owner or breeder. Not a moment was to be lost in supplying this deficiency, and with voluntary help and by dint of sitting up all night myself each judge found his special book awaiting him on his arrival the following morning. It may be inferred from this how often my heart was in my mouth. Had it not been for that casual remark of a steward, there would have been a complete deadlock, and judges, exhibitors, stewards and everybody else concerned would have thirsted for my blood, whilst my worst enemy could hardly have desired a finer advertisement of a new secretary's incompetence. In my then sensitive state of mind, the horror which possessed me when I realized the narrow escape I had had may be imagined, whilst I was oppressed by the harrowing thought that at any moment I might suddenly be landed in an equally serious difficulty without time to extricate myself.

Night and day I s'logged away, nearly wearing myself out in a strenuous effort to stave off the ever-impending catastrophe which would scatter my shallow pretensions to the four winds. But, happily, somewhat early in life, I had got a good grip of an old country saying, "It's dogged as does it," and the thought of this, as I applied the principle it represented, was distinctly encouraging in its hopeful possibilities. I knew that, although I was no genius, I had staying powers and a capacity for taking pains, the only possible hope for a man when the divine afflatus had not descended upon him, and, having brought these to bear, in 


\section{OXFORDSHIRE AGRICULTURAL SOCIETY}

the end, I weathered the storm. But the wealth of the Indies would never have induced me to go through such an experience a second time.

The Oxfordshire Agricultural Society, for the management of which I had made myself responsible, is of very old standing, having been founded so far back as 1811. At the time of my connection with it the show was held at Oxford and Banbury in alternate years by virtue of an amalgamation between the County Society and the Banbury Agricultural Association. After an experience of two shows, one at each of these two places, I came to the conclusion that the old Society had for some years past been slowly but gradually dying from sheer lack of nourishment, otherwise popular support; the worst of it being that few beyond those who got something out of it seemed to care very much whether it lived or died. The annual show, which was its main raison d'être, and should have been its sheet-anchor, was but a source of loss, owing to the sparse attendance at it; this being made up almost entirely of agricultural experts, who came to admire their own and criticize their neighbours' cattle. The ordinary townsfolk steered particularly clear of it, whilst, being so frequently held in one or other of two districts only, it lost the charm of novelty in those parts. It was evident to me that the Society was in a parlous state, and I had modesty enough to feel that I was not man enough to set it on its legs. So, having cleared up all outstanding matters and brought the accounts and all else into a condition enabling some one more capable than I was to take up the work without being faced by any 


\section{FIFTY YEARS OF A SHOWMAN'S LIFE}

complications, I betook myself to the president (Mr. Hugh Hamersley), chairman of Quarter Sessions, and one of the most influential and active public men in the county. To him I stated the position, and begged him to accept my resignation on the ground that I was quite unequal to the task of piloting the old Society to the haven of success. He listened to all I had to say, and then appealed to me, with that persuasive force which he knew so well how to use, not to desert the helm when the ship was in difficulties, but to stand by her and do my best to pull her through, promising me, if I would do this, all the help and support he could give me. I was touched by this appeal to the sentimental side of my feelings and by the confidence it implied, and so, against my better judgment-as I then thought-I yielded, not having, on the spur of the moment, the heart to refuse. I little thought then that he was entrusting me with a mission which was to be the turningpoint of my life, leading to undreamt-of possibilities.

Having irrevocably committed myself, I buckled to with the determination that if I had to admit defeat it should not be due to faintheartedness, and that whatever backers I had should have a run for their money. Although, as I have confessed, I was barren of so much that I ought to have known, my friendly relationships with individual agriculturists from boyhood upwards had given me an opportunity of acquiring a personal knowledge of bucolic idiosyncrasies, which stood me in good stead. Hence, when, as an official, I was brought into close connection with agriculture and its representatives, I had 


\section{THE FARMERS' CLUB}

a better and more sympathetic appreciation of their point of view of things than would have been the case without my previous experience. Beyond this, it gave me acquaintance with the social manners and customs of farmers and taught me that, if you want to get on the friendliest of footings with them, you must make yourself one with them in this respect. The following incident indicates that I had some realization of this pretty early in life.

Farmers did not, in the time of which I have been speaking, lose sight of their creature comforts, even in the midst of serious business, often transacting it with accompaniments, which solaced and cheered as well as stimulated. They frequently did so when they met in conclave to discuss such problems, in connection with their occupation, as they were faced with. This was borne in upon me at a comparatively early age, upon the one solitary occasion when my father deputed me to represent him at an agricultural gathering. My father was the founder and secretary of a Farmers' Club, which met at monthly intervals on a market-day at one or other of the hotels in the county town. It happened on the day of one of the meetings that my father was suddenly called away from home on other business. $\mathrm{He}$, therefore, directed me to represent him at the meeting. I was but a schoolboy-it was at the end of the 'fifties - and was rather taken aback by the tallness of the order, as I had never been intrusted with such an important mission before. However, I had unbounded confidence in my father, whose will was my law, so I made no bones about 


\section{FIFTY YEARS OF A SHOWMAN'S LIFE}

going, but simply asked for instructions. These were not very elaborate; they consisted merely of "Apologize for my absence to the chairman, read the minutes of the previous meeting, and-well, do whatever else you think I should do."

The members of the club met first at dinner at the market-ordinary-a function my father did not think it necessary for me to take part inand then adjourned to a large room attached to the hotel for the transaction of the routine business; followed by the reading of a paper and a discussion thereon. The reader of the paper was a wellknown agricultural parson, the Rev. C. Clutterbuck, rector of Long Wittenham, Berks, who was a great authority on Thames floods, the subject of it being "Arterial Drainage." The chairman having taken his seat, I made my bow and delivered my message, and then proceeded to read the minutes. After this the presence of the waiter was remarked, and forthwith most of those in the room desired him to furnish them with a long clay and something to fill it, and a glass of hot brandy and water. It was clear to me that this was the correct thing to do, and, as I was very anxious to carry out my instructions, and to maintain the secretarial character to the best of my ability, I felt I must follow the lead given, which I did.

After the reading, during which everybody, including myself, solemnly smoked and sipped, the waiter again entered the room, and the previous orders were duplicated. With a stern determination to do my duty at all hazards, I took my courage in both my hands, and handed 


\section{BRANDY AND BACCY}

up my glass for replenishment, accompanied by a request for another "screw" of tobacco-I was a reader of Dickens, whence I gathered this was the correct term. I hoped, however, that I should not be expected to keep on at this for long. When all were supplied, the discussion, a spirited one, took place, and the reader having replied, the proceedings terminated, much to my relief, and I wended my way homewards, particularly pleased with myself. Incredible though it may appear, I was as sober as a judge, and free from any of the inconvenience usually resulting from "lighting up" too early. Had it been otherwise, I am sure my memory would not have served me as well as it has in recalling the events of that afternoon. I can only suppose that, in my desire to fulfil adequately what was expected of me, my nerves were in a state of extreme tension-strung up to concert pitch, in factand so overcame any ordinary physical disability.

My father, on his return, examined me as to my proceedings at the meeting, a truthful account of which I gave him. When I imparted to him my crowning and successful effort to adapt myself to the manners and customs of the company in which I found myself, he was utterly flabbergasted. Being asked what I meant by such goings-on, I found I had to be on the defensive. But "fortune favours the brave," and a happy thought came to the rescue, which found expression in, "Why, father, didn't you tell me I was to do just what I thought you would do-and I did it!" My father, apparently having no suitable answer to 


\section{FIFTY YEARS OF A SHOWMAN'S LIFE}

this ready, relapsed into silence, and I felt I was saved.

The following Saturday he happened to meet the chairman of the meeting, William Thomson, a Scotchman, and, with some misgivings, said to him: "I hope my boy did all right in my absence at the Farmers' Club." "Ay," replied Thomson, "your laddie did reight enuech," and then added, as a sort of after-thought, "and he taks his pipe and his glass every bit as weel as his feyther." I ought, perhaps, to add that this experience did not engender any permanent attachment to either tobacco or brandy and water, for I don't smoke, and I prefer water when it has no brandy in it. But my father never gave me another chance to do deputy for him at the Farmers' Club. He may, perhaps, have thought that I somewhat over-acted the part on the occasion referred to; but he was very reticent on the subject.

I daresay many well-regulated persons would say I ought to have been ashamed of myself for such precocity. But I wasn't at the time, and never have been since. Rather the contrary, because $I$ knew the motive was all right. What was all-paramount in my mind was the desire to live up to what was expected of me. I have always had a morbid horror of falling short of anticipations, and perhaps I should have had an easier time all these years if I had attached less importance to this. Still, I think, on the whole, it has stood me in good stead, and made amends for the lack of more shining qualities. So I will not counsel the rising generations - -unless the heavenly 


\section{"THOMSON, OF CULHAM"}

fire of the immortals has descended upon them, when, of course, they can do without anything else-to fight against the impulse which led me to brandy and baccy at the Farmers' Club.

The chairman above referred to, "Thomson, of Culham," as he was usually designated, to distinguish him from other Thomsons in the same parts, was a notable agriculturist. He was one of those shrewd, hard-headed Scotchmen who came over the border in considerable numbers in the first half of the last century, and who, by their advanced methods, combined with practical experience, showed how two blades of grass could be produced where only one had grown before. He was a forward spirit, who had outgrown the fallacy that the whole art of agriculture was summed up in the axiom that "muck is the mither o' corn." The canny Scot, who came southward from his native wilds, was usually better equipped educationally, thanks to the parochial school system of the land of his birth, than his agricultural brother in England, and his success in life was likewise aided by an inborn thriftiness and an instinctive faculty for obtaining full value for every penny laid out; consequently most of them did very well for themselves. Many of them became the agents or stewards for large estates, their natural capacity for getting the most out of anything they were responsible for being just the qualification which best appealed to landowners in want of managers for their property. Thomson was a remarkable instance of the value of "real grit" in a man, for, although he tramped it into this country with little more than the 


\section{FIFTY YEARS OH' A SHOWMAN'S LIFE}

clothes he stood upright in, he made a fortune out of farming before he died. He did so, at the same time earning the goodwill of those in whose midst he had prospered, who, in the closing years of his career, showed their regard and esteem for him, and their appreciation of the services he had rendered to agriculture, by a handsome presentation of plate. He frequently visited my father, and he greatly impressed me, as a youngster, for three reasons. One was that he was the tallest man I had ever seen, having to stoop before he could enter the full-sized doorway of our diningroom; another was that he had, in his younger days, known and conversed with Sir Walter Scott, which placed him on a pinnacle in my young eyes; and, thirdly, that he drank more tea at a sitting than any one I had ever beheld or thought capable of. He was the despair of my mother in this respect, because an ordinary tea-cup was to him but a thimbleful. 


\section{CHAPTER IV}

The Discovery of the Key of Success-Political Strategy-The Assistant Secretary-The Working of the Spell.

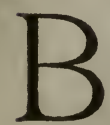

EING satisfied that lack of interest was the particular disease from which the Oxfordshire Agricultural Society was suffering, the main point was to settle how this could best be combated, and I will go into particulars as to how it was done, for the information of any show committee who, in the cold shadow of failure, may be wondering how they might retrieve their luck. The holding of the annual show at only two centres was, for reasons already specified, apparently one of the causes of failure. This suggested the adoption in lieu of it of the migratory principle, which would give each town in the county a visit in turn. The idea having been ventilated, an enterprising inhabitant of Thame confided to me his belief that that township, if properly approached, would be willing to receive the Society, and pay something for the privilege. A nod is as good as a wink to a secretary at his wits' end to find the key to success. So I at once resolved to lay siege to Thame, although the only soul I knew in the place was the inhabitant referred to. Having journeyed thereto, I made at once for the chief hotel and ordered lunch-chops and 


\section{FIFTY YEARS OF A SHOWMAN'S LIFE}

a pint of sherry, as I well remember. I may say that this was well in excess of my needs, half the quantity mentioned of meat and drink being amply sufficient. But I was anxious to create a favourable impression, and so thought it good policy to do the thing handsomely. The waiter, soothed by a tip, was communicative, and willingly responded to my inquiries respecting the locality and its inhabitants. We mutually agreed that its main weakness was a lack of the bustle of life, and what it chiefly wanted was a livening-up ; in fact, it was undeniably Thame in a double sense. Having arrived at this conclusion, I requested my informant to convey to the landlord that I was desirous of converse with him.

The latter having joined me, I delicately suggested to him that on this, my first visit to Thame, I could not fail to be struck with its general air of sleepiness. He agreed, but counselled me to come and see it on market-day, when it would be at its best. I then pointed out what an advantage it would be if people in large numbers were attracted to it, and public interest were focused upon it. People who were induced to visit the town might then become permanent residents in it. $\mathrm{He}$ cordially acquiesced in this, but did not see how it was to come about. That brought matters to a point, which enabled me to hint that, if the views we had exchanged were endorsed by the inhabitants generally, I had reason to believe that something definite might accrue from it. The fact was-as I explained in a burst- of confidence-an important agricultural organization was considering in what favoured locality it should hold 


\section{A BOLD STROKE}

its next show, and that if Thame were quick about it it would stand a good chance of being selected. Further, I pointed out that the amount of money that it would cause to be spent there, particularly in connection with the hotels, would be very considerable. All the judges and stewards would have to be boarded and lodged, especially at the principal hotel, and there would be show catering and a grand annual dinner, which the county M.P.'s would attend, to be provided. The landlord took so kindly to the idea that, abandoning further reticence, I went a step further, and confided to him that what I had in my mind was a visit from the famous Oxfordshire Agricultural Society. I advised him to look up the townsfolk at once, and, if they were equally favourable, to get a public meeting called, at which resolutions could be passed inviting the Society, and opening a subscription list, as the Society would expect $£ 100$ down and a suitable site for a Show Yard provided free of cost to it. Having put the matter so far in train, other negotiations followed, and ere long I was able to report to my committee that there was a burning desire on the part of Thame to receive the Society, and to conform to the conditions with respect to the monetary payment and a show yard. This would put us in a $£ 100$ better position to start with than we should be at either Oxford or Banbury.

Then I felt I had something worth talking and writing about, and newspaper-editors, whom I interviewed, saw with me that if we could keep the old Society afloat it would mean orders for advertising and printing, which serve to sustain 


\section{FIFTY YEARS OF A SHOWMAN'S LIFE}

newspapers as well as Societies. So I got the run of their columns for "booming" purposes, and, thus encouraged, I wrote an article on the subject that possessed my mind, and secured its insertion in leading-article type, in an influential Oxford paper. I knew the liking of country-folk for an old saying, so I headed my anonymous contribution, "There's Life in the Old Dog yet," and it can be imagined how the text was applied. This caught on, so I had a large number of copies struck off and circulated in all likely quarters.

It will be seen, as I proceed, from what small beginnings genuine and spontaneous enthusiasm, as we suppose it to be, is created, and how much it owes to the working of the bellows to keep the flame alight. If anyone fancies nowadays that any particular world upon which he has set his heart is to be conquered by a policy of judicious reticence, he is likely to fall a victim to that hope deferred which maketh the heart sick. At the same time, there is infinite truth in Barnum's dictum: "If you have got hold of a real good thing, you can hardly spend too much in advertising it, but, if it does not answer to this description, it will never, in the end, pay for exploiting it."

Since writing the foregoing exposition of the policy I pursued in compassing a certain end, I have had the extreme pleasure of discovering that fifty years ago I was by anticipation the unçonscious disciple, in a very humble way, of the present Prime Minister. In a recent great historic speech he said: "I made up my mind to take risks, and I took them in order to arouse public sentiment." "It is not easy," Mr. Lloyd 


\section{POLITICAL STRATEGY}

George proceeded to say, "to rouse public opinion. I may know nothing about military strategy, but I do know something of political strategy. To get public opinion interested in a proposal and to convince the public of the desirability of it is an essential part of political strategy. That is why I did it. And it has done it." The Premier has exactly described what was in my mind when I started on my campaign, and after so eminent an endorsement of the policy I pursued I can have no hesitation in commending its adoption to anyone who may be in a similar position to that in which I then found myself, whilst no one could desire a better-sounding definition of a means to an end than Mr. Lloyd George has supplied. In my own case, as well as in that of the latter-day apostle of the creed, the objective aimed at was fully attained, and, as nothing succeeds like success, this in itself supplies the only other justification required for " political strategy."

Having baited the fishing-ground, other likely means for inducing our fish to rise were thought of. We looked into our internal economy, and, with other modifications of procedure, remodelled the constitution of the committee, making it more representative of the whole county, and, instead of having a permanent president, agreed to elect a different one annually, selected from the district in which the show for that year was to be held.

Every county man of good standing was asked to become a vice-president, which would render him eligible for the office of president of the Society. The arguments backing this up were sufficiently conclusive to secure a large body of 


\section{FIF'IY YEARS OF A SHOWMAN'S LIFE}

additional support; in fact, we had hardly a refusal.

The Society had no funds worth mentioning, nothing material to fall back upon if our new schemes led to financial disaster, so we had, amid many misgivings, to live mainly upon faith with an intermingling of hope by way of sustenance. This being so, the utmost economy in administration had to be practised. 'The Society's resources were not equal to the provision of an office-staff, any more than was the secretary's honorarium. But, though lacking worldly means, I had not long previously-being in sore need of companionship-taken unto myself, among other serious responsibilities, what turned out to be quite a valuable acquisition in the shape of a better-half. This went far to solve the staff difficulty, inasmuch as I graciously conferred upon her the rank and title of "assistant secretary," with all the emoluments, perquisites, etc., pertaining thereto. These were limited mainly to such honour and glory as the status of the position represented.

The appointment entirely justified itself, being quite a success in many ways, the new official rising to the occasion, and taking her duties in a thoroughly serious spirit. With feminine resourcefulness, she organized working-parties of lady friends, who foregathered for tea and the addressing of envelopes, and for the doing of other clerical work suited to their capacity. As her activities developed, her hand in affairs became more manifest, and correspondents became curious to know how it was that office-communications 


\section{THE ASSISTANT SECRETARY}

were so ladylike in their caligraphy. These, of course, were days anterior to the advent of the lady-clerk, when those of the gentler sex were supposed either to devote themselves to spinning or its modern-day equivalent, or to sit with folded hands; any participation in male activities was in genteel circles apt to be regarded as unladylike. I am not at all sure that suspicions were not aroused in some homesteads when envelopes arrived on which the pot-hooks and hangers bore the evident impress of feminality. However, the raising of the veil set all doubts at rest, particularly when it was realized that it was the only way of getting necessary work done. So ere long the new official became in the minds of the members part and parcel of the establishment, and when, on festive occasions, the toast of the secretary was honoured, it was usual for a supplementary and complimentary recognition of his co-worker to be called for. This being a faithful record of how I fought my way towards my ultimate goal, and how I was able to tide over many real difficulties, I should be claiming too much credit for myself did I not acknowledge my indebtedness to one whose help went far towards enabling me to hold the fort.

Then came the eventful day in May, 1871, when the success or failure of the Thame Show would go far to decide the future fate of the Society and myself. The sky was lowering, but our spirits rose as the country-folk poured in, though there was more rain than one liked. But, notwithstanding that the elements were somewhat against us, there was a bustle and go about the 


\section{FIFTY YEARS OF A SHOWMAN'S LIFE}

proceedings that former shows had lacked, whilst the attendance was well ahead of previous records. Then, for the first time in the history of the Society, we had some lady exhibitors, a great novelty in those Mid-Victorian days, and pour encourager les autres I trumpeted their enterprise far and wide as the happiest of auguries. Although we did not quite clear expenses, we were a deal nearer this than we had been for years, whilst the Society obtained a good advertisement of itself, as was shown by the fact that two towns, Bicester and Witney, competed for the honour of receiving it the following year.

So the curtain fell upon the first act of my little agricultural drama. I had-reverting to my old theatrical days-what was equivalent to a call before the curtain at the finish, for, at the annual dinner which crowned the show-day's proceedings, I was brought into the limelight by those who would not be denied. And so I suddenly found myself on my hind legs and for the first time in my life addressing an enthusiastic gathering of agriculturists. After all I had gone through, after the ever besetting dread that for so long possessed me that my lack of essential knowledge and experience would land me in the hopeless quagmire of failure, I should have been either more or less than mortal if I had not been full in heart and uplifted in spirit as I looked round at the sympathetic souls, who in this way brought home to me that I had come into the day's reckoning. Had the mantle of a prophet fallen upon me I should have seen that this was but the forerunner of half a century's kindliness on the 


\section{MAKING HEADWAY}

part of a section of the community-semper fidelis, semper eadem - with whom I was destined to have much to do, and who, whether as owners or cultivators of the soil, have left me equally their debtor.

Our hopes at Bicester the next year were dashed owing to our having pitched upon the most pitiless of wet days for the show, the rain descending in an interminable torrent from morn till night. The one consolation was that the rain came just when it was needed to save the crops, which had been suffering from previous drought. This damper put us back a bit, though the attendance of paying-visitors, numbering over 2000, was much better than we could have expected under the climatic conditions, whilst the exhibition of stock and implements was the largest the Society had ever held. 


\section{CHAPTER V}

A Bit of Sport-The Question of Supplementary Attractions-A Practical Committee-The Future of Shows.

T' $\mathrm{T}$ was at Witney the next year that we may be said to have turned the corner, for the

1 show was a triumphant and unequivocal success. The weather did its best to make amends for its previous endeavours to throw cold water on our efforts, for it was a brilliant day. Another circumstance-a piece of exceptional luck-was an immense help to us. Two wellknown sporting farmers in the district who had a good hunter apiece had long had a friendly dispute as to which of the two animals was the best goer. In those days jumping competitions had not become a feature of agricultural show yards, but the Oxfordshire Society, under the new régime, was a bit in advance of the times in several respects. So we took our courage in both hands, laid out a regular steeplechase course round the yard, and offered a prize for the horse that negotiated it best; having first satisfied ourselves that the two farmers in question would bring their horses to the test and thus settle the merits of the animals and a long-standing bet at one and the same time. The event was noised abroad in all directions, for such a trial of strength was 


\section{NEW METHODS}

the very thing to appeal to the sporting instincts of town and country alike. Consequently, the rush into our show yard to witness the contest was something to delight the hearts of all concerned, the secretary especially. But it could not be said that agriculture was sacrificed on the shrine of sport, for the show of stock, implements, etc., was more extensive than any one previously held in the county, and the crowds attracted by the bit of sport did not confine themselves to this, but took the opportunity of seeing all they could of everything else ; to their benefit, from an educational point of view.

But another innovation, so far as the Oxfordshire Society was concerned, was introduced for the first time at Witney. When the old methods had failed and new ones had to be found, I went, notebook in hand, to other show yards to pick up what I could. At one of the shows I attended music was made a special feature by the engagement of a first-class military band, and when I saw a dense throng round the bandstand at all hours of the day when music was going on, spellbound by its charm, I returned home thoroughly impressed with the idea that here was another means of bringing grist to our mill. The result was that, for the first time in the Society's annals, a military band-that of the Life Guards-discoursed sweet music at the Witney Show, and ever since music has been one of the attractions.

We made enough out of this show to set us on our legs and relieve us of any doubt as to the wisdom of our new departure in adopting the 


\section{FIFTY YEARS OF A SHOWMAN'S LIFE}

migratory principle. Years afterwards, the Royal Agricultural Society of England had the value of this principle forcibly brought home to it. It was a curious fact that more Oxford residents took the trouble to travel to Witney to see the show than ever visited it when it was at their own doors, and this experience was repeated in afteryears.

The question of supplementary attractions not strictly agricultural at shows was for long a subject of acute controversy in agricultural circles, but the logic of facts has practically settled the matter, for it is now generally admitted that the turnstiles would never click fast enough to pay expenses if such attractions were not forthcoming, nor would societies be able without such assistance, owing to lack of funds, to help agriculture to the extent they do now. So, as the old saying has it, "You must go for the bridge that carries you over." You not only want the shillings of the agricultural expert but those of his women folk also and of the man in the street as well. We live in an age of competition, and many rival attractions have sprung up in recent times to tempt the ordinary pleasure-seeker. It is an age, too, that pays little deference to mere tradition, and, consequently, no institution can permanently live upon memories of the past. Whether it be a business or a society, it must nowadays possess the power of adapting itself to modern conditions if it is to hold its own. The old show programme, which took cognizance only of the tastes of the agricultural section of the community, is too restricted for to-day, and a wider circle has now to be appealed to. How 


\section{POPULAR ATTRACTIONS}

far then is it prudent, and politic to go in the matter of supplying the modern demand for what are termed "popular attractions"? Whilst no hard-and-fast line can be drawn, because local conditions are an element in the case, I hope and believe that our shows, when they rise rejuvenated after the war, may be able to fulfil their mission without following the example of those in the Colonies, where a large portion of the show yard partakes of the nature of a country fair, and where acrobats, contortionists, performing animals, et hoc genus omne, are allowed to disport themselves.

I would substitute for these plenty of good music, floricultural displays, and exhibitions illustrative of arts and crafts and village industries. In the matter of attractions, I think, in this country at any rate, we can safely trust what has been described as "the great body of middle opinion," which typifies in itself solid, sober, British common sense-likely to be well represented on Agricultural Show Committees-which would know where to stop. We have most of us come round to the opinion that no open-air agricultural stock show can exist without recognizing the sporting instincts of Englishmen by the provision of jumping competitions, and it is satisfactory to find, on the testimony of judges of wide experience, that this has not resulted in attracting only " circus horses," trained to negotiate a series of show-ring obstacles, and good for nothing else. As these competitions have become more general, the quality of the horses entered has distinctly improved, and their aggregate monetary value has largely increased. At the same time, the introduction to the show yard 


\section{FIF'TY YEARS OF A SHOWMAN'S LIFE}

of such competitions is not to be defended on any higher ground than that of expediency and as a means of assisting societies to carry out their primary objects. Anything not strictly agricultural should not be allowed to absorb the chief energies of a society, but must be regarded merely as a help to provide the sinews of war for the promotion of more essential work.

How good a working committee was that of the Oxfordshire Society may be judged by the presence on it of such notable agriculturists, whose fame extended far beyond the limits of their own county, as the three Druces, Joseph, Samuel and Milton, John Treadwell, W. Hobbs, the Gilletts (C. and J.), George Street, Charles Howard, the two Garnes (G. and T.), A. T. Matthews, and T. Latham. These, and others I could name in the same connection, were well known in every show-ring in the kingdom, whilst their reputation among breeders extended to our Colonies and America. Several of those I have named will be recognized as being among the founders of the Oxford Down breed of sheep, and to whose ability, in perfecting it and making its merits known, was due its recognition by the leading agricultural societies in the kingdom. Milton Druce was the breeder of the celebrated ram "Freeland," which, as Sir R. H. Rew once said, "is to the Oxford Downs of the present day very much what "Eclipse" is to the thoroughbreds." In addition to honours elsewhere, it achieved the remarkable distinction of winning the championship, open to all the world and to every breed of sheep, at the great Centennial Exhibition at Philadelphia. 


\section{GOOD MEN AND TRUE}

Milton Druce was one of those men whose knowledge, experience, and integrity count for much in the practical work of the show yard, and his services as a judge were constantly requisitioned by the leading societies. A close intimacy sprang up between us in my Oxfordshire days and was intensified afterwards, for he was a member of the Bath and West Society's Council and its senior steward of stock. He it was who urged me to become a candidate for the secretaryship of that Society, and I owed much to his advocacy when the selection was made. He was one of the most single-minded, God-fearing men I ever met, and his death, which came all too early, was a real sorrow to me. At his decease he was occupying my old post as secretary of the Oxfordshire Agricultural Society.

I rejoice that there are two left-I fear only two-of that Oxfordshire Committee to which I have referred, one of whom, my old and valued friend, T. Latham, of Dorchester, Oxon, has since those days been elected a member of the Bath and West Society's Council, and has rendered it yeoman service as a show yard steward; the Shoeing and Milking Competitions of the show, especially, owing much to his practical knowledge, initiatory power and never-failing energy. As an active member of the governing bodies of such representative agricultural institutions as the Central Chamber, the Farmers' Club, and the Smithfield Club, among others, he has given valuable aid to the country-side, while earning the goodwill of those with whom he has acted.

A. T. Matthews, too, is still, I am glad to say, 


\section{FIFTY YEARS OF A SHOWMAN'S LIFE}

in the land of the living. He went out of farming many years ago, but since then has used his pen to good purpose, giving the world, by means of it, the benefit of his practical experience, as the Journal of the Bath and West Society amply testifies. In addition to this, the Central Chamber of Agriculture is indebted to him for one of the best of secretaries in the person of his son, A. H. H. Matthews, whose ability and services were not long since recognized by the conferment upon him of a knighthood.

After the success at Witney there was no further need for anxiety as to a place of meeting, for there was always an invitation forthcoming, and we were able to arrange a regular circuit of towns, which allowed of the different quarters of the county having the show in turn. This was good evidence of the improved status of the Society and its power to attract popular support.

But, although there is much truth in the saying that "nothing succeeds like success," we felt that that would not justify a relaxation of effort. We had, in the phraseology of our school-days, to "keep the pot a-bilin'," and, as an old showman, I can testify that there is no more finality in show programmes than in mundane affairs generally. So, encouraged by the fortune that favoured us, we went full-steam ahead on a progressive road. Having increased the number of stock classes and correspondingly the amount of prize-money, we launched out into a two-days show, and carried out the building of the show yard upon a much more complete and elaborate scale than previously. All this, with a general 48 


\section{AN AGRICULTURAL AWAKENING}

levelling-up in matters of detail, added both to the Society's prestige and to its financial resources. So the old Society, phœnix-like, rose out of its own ashes into a higher position than the most sanguine of its supporters ever anticipated its attaining, and took rank as one of the leading provincial associations of the kindgom.

At the present moment agricultural associations, especially those holding shows, have to defer to war-time conditions and suspend the main feature of their operations. Owing to such conditions, brought about by force of circumstances, and by _ special legislative enactments necessary in order to meet the exigencies of the abnormal times in which we live, agriculture may be said to be very much in a state of flux. One thing, however, is abundantly clear, that it will, in the public estimation, hold a very different position in the future to what it has done in the past. A stern awakening has brought forcibly home to the mind of the kingdom at large, what practical men so long urged in vain, that our very existence as a nation may be dependent upon the extent of our agricultural resources. When one looks back upon the general neglect, on the part of the State, of the greatest of our national industries -in the days when the latter had no representative Government department to protect its interests-one can better appreciate the magnificent service in the cause of good husbandry and in co-ordinating and stimulating the efforts of those interested in it, rendered by the agricultural organizations, relying entirely upon voluntary support. It may further be remembered that 


\section{FIFTY YEARS OF A SHOWMAN'S LIFE}

other Continental Powers have thought it worth while for many years past to lavish tens of thousands of pounds annually for the carrying out of the very work to which our voluntary associations were devoting themselves without a charge to the taxpayer of a single halfpenny. The aid of these organizations will be more than ever necessary to agriculture and the nation at large when peace returns, and all who realize this must unite in their support.

The rekindling of interest will have to be energetically and systematically undertaken, and it will be very much a fight for existence with many societies, resulting in the survival of the fittest. A record of good service in the past always counts for much, but is far from being all-sufficient. There is some truth in the assertion that "gratitude is a sense of favours to come," and societies will have to show their capacity to fulfil expectations in order to count upon that gratitude which expresses itself in a rendering of such practical help as is represented by a provision of the sinews of war. 


\section{CHAPTER VI}

The Festive Side of Agriculture-Carving Simplified-Speech and Song-Lemonade and Gin.

$\Lambda$ ND now, having referred to the more prosaic side of a showman's life, I will say something of its lighter aspect and of the company I kept.

There was a good deal more public eating and drinking forty or fifty years ago among agriculturists than now, for advantage was taken of every possible excuse for meeting round a festive board. Of course, the war has stopped most of such gatherings, but before ever the war was dreamt of the dimensions and number of agricultural dinner-parties had lessened. In addition to the ordinary Agricultural Society dinners, there used to be what were termed pleuro-pneumonia dinners, when members of a sort of Insurance Society against live-stock diseases met to cast up accounts; Christmas dinners, at which all who attended the weekly ordinaries at certain hostelries foregathered, the landlord supplying the eatables at his own expense, while the company paid for the drinks; hunt dinners; ram-fair dinners: ploughing-match dinners, and many others. They mostly began at two o'clock, and often went on till long after dark. They were Gargantuan 


\section{FIFTY YEARS OF A SHOWMAN'S LIFE}

functions, and were not so remarkable for the number of courses as for the solidity of the fare. Everything to be eaten was put on the table and carved by the diners themselves, and a pretty uproar there would have been if the eatables, as now, had been carved behind a screen, without anybody who was to partake seeing that they were real boná fide joints, at which you could cut and come again. Besides, how could Farmer Jones indicate the particular cut he had a liking for when he couldn't see the joint? When in more select circles dîner $\hat{a}$ la russe was introduced, I remember the scorn and contempt with which the news was received at one of these old-fashioned sort of dinner functions to which I am referring. Some one had "heard tell" of this extraordinary new procedure, which was considered to be "just what you might expect from Russia," but which "would never go down with Englishmen, who wanted everything fair and above-board." But, other times, other manners !

I have known occasions in those days, although not in connection with agricultural dinners, when diner à la russe would have resulted in a fairer apportionment of edibles than could be ensured under the old system. A friend of mine once gave me an illustration from his own experience of what could happen when the diners were their own carvers. If simplicity and celerity were alone aimed at, the method of food distribution he described would be hard to beat. It occurred at a dinner annually held at Oxford by a friendly society on New Year's Day. Considering the quality and quantity of the fare it was a very 


\section{A CHEAP REPAST}

cheap repast, inasmuch as anyone, applying through a member of the society, could obtain a ticket on payment of a shilling, which entitled him to all he could lay his hands on at the festive board. This was possible at the price owing to the liberality of certain town and country folk, who made presentations of joints, game, etc., for the good of the cause. Although politics were supposed to be strictly tabooed, the local Parliamentary representatives always regarded it as an opportunity to give some account of their stewardship. I have enjoyed on these occasions the precise and polished oratory of the late Viscount Cardwell, and, following it, the more outspoken cut-and-thrust declarations of Sir William Harcourt.

Candidates desirous of supplanting the sitting members also took advantage of the gathering to advertise themselves. This resulted in the leaders on both sides of politics acquiring a number of dinner tickets for free distribution among staunch partisans of limited means. These, as the least return they could make, gave something of the nature of a quid pro quo by providing most joyous demonstrations of approval when any of the shining lights of their particular party took the floor. As may be imagined, under these circumstances, the company was somewhat mixed, and this applied also to some of the manners and customs of those who were present. To many of these the chance of so abundant a repast at somebody else's expense came but seldom, and it was said that the more ardent spirits went into strict training beforehand, so that, by means of previous 


\section{FIFTY YEARS OF A SHOWMAN'S LIFE}

abstentions and in other ways, they were enabled to bring to bear unexceptional appetites, or, as they put it, to "come up to the mark sharp-set." Among those who had left no stone unturned in this direction was a free-fooder, whom I knew very well by sight, one Sam Bemister, renowned on the banks of the Isis for his prowess as a boatman. His bodily frame was of very ample proportions, and no doubt liberal rationing was required for its proper upkeep. At any rate, this was Sam's opinion, which he reduced to practice when he attended, as he usually did, this festive gathering.

On the occasion in question I was not sitting sufficiently near him to observe how he comported himself. My friend, however, from whom I derived particulars of what transpired, was Sam's vis-à-vis, whilst Sam's brother was seated alongside Sam. Between the latter and my informant a couple of ducks was placed, and my friend, not feeling equal to dissecting them, said in the blandest of tones, "Mr. Bemister, will you kindly carve those ducks?" "Cert'nly," said Sam, and with that, and without a moment's hesitation, he stuck his fork into one duck and handed the latter on a plate to his brother. He then plunged his fork into the breast of the other duck and deposited the bird on his own plate, remarking with pleasant affability to those around "That's how I carves dooks!" The witnesses of this annihilation of their fondest hopes looked unutterable things, but Sam was too well set-up and too long in the reach to admit of any free expression of views as to his method of carving. The carver himself regarded the consumption of such an insignificant trifle as a duck 


\section{AGRICULTURAL DINNERS}

as merely a preliminary canter preparatory to doing full justice to the baron of beef, a standing dish on these occasions, and any minor comestibles coming his way.

This happened a good many years ago, before the Education Act and other influences had done something, as the Latin grammar phrased it, to "soften men's manners," and to induce them to cultivate the amenities to a larger extent than was thought necessary in those more rough-and-ready days. So, if the old dinner is still kept up, there is no fear, especially now we are under a Food Controller, of such individual commandeering as I have described. It is, nevertheless, satisfactory to feel that the general adoption of dîner à la russe puts it out of anyone's power to favour such an unequal system of rationing as was possible in more primitive times.

At agricultural dinners a considerable volume of liquor was required to wash down the eatables, and it was of a very varied description. Agriculture was fairly prosperous at that time, so there was not much stint in the matter of wines, and after a generous allowance of sherry, champagne, and port had been enjoyed by the whole party collectively, individual groups adjourned to the bar-parlour and fortified themselves for the homeward journey by draughts of either hot brandy and water or lemonade and gin; the former being the drink most affected by the older and more matured section of the company and the latter by the younger and more dashing contingent. I daresay, however, that the liquors varied in different counties. Whiskies and sodas had not 


\section{FIFTY YEARS OF A SHOWMAN'S LIFE}

then come into fashion. The consumption of liquor was not a little stimulated by the idiotic custom, now happily a thing of the past, by which everybody was expected to take a glass of wine with everybody else. Notwithstanding all this, it was very rare to find anyone on these occasions notably the worse for what they had taken. There was a good deal of harmless joviality, but nothing more marked than what used to be described as "market-merry" ; a condition of mind and body which was not regarded as a reproach to any one, but rather as a proof of his capacity to carry good liquor without allowing it to master him.

Two farmers, well known in my parts, started on their homeward way after such a festivity as I have described. They were friends and neighbours, and came to the entertainment under a mutual arrangement, by which one lent the gig for the journey and the other the horse. The liquor in this case, as it sometimes does, engendered a "touchiness" foreign to both of them at ordinary times, and, on the homeward way, a warm dispute arose with regard to a very trivial matter. At last, one of them losing all patience, said to the other, "I won't put up with you a minute longer! It's my gig, and you get out of it." "All right," was the reply, and down he got and at once began to unharness the horse. "What are you at?" said the one in the gig, who, in the darkness of a country road couldn't very well see what was going on. "Only taking the horse out! You see, the gig's yours, but the horse is mine." Having released the horse from the shafts, he wheeled the gig to one side of the 56 


\section{WHEN "SILENCE IS GOLDEN"}

road, and then, mounting his steed, rode home on it, leaving his fellow-passenger to spend the night in solitary state under a hedge and the stars of night, some miles from the haven where he would be. It allowed him ample time to chew the cud of reflection, and to ponder upon the truth of the axiom that, under some circumstances, silence really is golden. I am glad to be able to record that the incident did not lead to any permanent estrangement. It was not long before the matter was made up, and each admitted to the other that he was wrong, whilst for the rest of the world who got wind of the transaction the pair jointly summed up the situation by piously ejaculating: "However we could have been such a couple of darned fools we can't think!"

These dinners possessed two distinguishing features-which altered times have done very much to curtail-the speeches and the songs. The former were not notable as oratorical efforts ; it was the number of them delivered at one sitting that was so remarkable. Even in a fairly large company it not infrequently happened that before the entertainment had concluded the health of every person at the table had been proposed and responded to. I have known the proposer of a toast remark that all he could say of the gentleman whose health he was about to propose was that he was the only one who had not already been thus honoured, and he didn't see why he should be left out in the cold. Happily, most of the speakers were, like this one, soon gravelled for lack of matter, so that they were not on their 


\section{FIFTY YEARS OF A SHOWMAN'S LIFE}

legs for long, otherwise the proceedings would have been more protracted than they were. In those days there was an absolute craze for speechifying at meal-time, and an old friend of mine who used to give gorgeous repasts would, even when they were within the privacy of his own residence, insist upon a delivery of post-prandial orations, on the ground, as he put it, that anything was better than "sitting mumchance"; a fine old country-side phrase not to be met with nowadays except in ancient books.

I have heard of a parson, who, requested by his host to give another toast, and discovering no one round the table whose health had not been honoured, proposed, with a view to finality in the matter, "All people that on earth do dwell." Such comprehensiveness then permitted him to enjoy his port in quiet.

Professional vocalization was not de rigueur on these occasions, the assembled company much preferring their own unaided efforts, and there was a distinctive character about many of these which certainly would have been lacking in any paid contribation to the evening's harmony. In those days music halls were negligible quantities, so far as agriculture was concerned, nor did farmers journey so frequently as now to town. Hence, we were spared a repetition of the comic, so-called, effusions of the lion comique of the period, and we had something much better in their stead. Hunting songs were always well to the fore-the special favourites being "A Southerly Wind and a Cloudy Sky," "Old Towler," "We'll all go a-hunting to-day," and, of course, "John Peel." 


\section{VOCAL HARMONY}

Farmers, in these more strenuous times, are not able to follow the hounds so often or in such numbers as they did in the days to which I am referring, but the old enthusiasm for the sport is far from dying out. When the Bath and West Society met at Newport in 1907 there was the customary State function in the shape of a civic banquet, attended by representatives of both Houses of Parliament and many dignified officials. In the midst of set orations of more or less solemnity, some one hinted that, if a particular nobleman in our midst could be induced to give tongue with "John Peel," it would be something worth listening to. With a good nature, which was appreciated to the full, then and afterwards, the acting president (the present Lord Radnor) responded to the desire expressed, and in a way which amply justified, by the pleasure it gave, this unusual call upon a president's powers. Nobody had ever heard the old song sung better, and the way in which the whole company lent itself to the rendering of the chorus and the final "tally-ho" was a testimony to the enthusiasm which, even in these latter days, the sport could evoke.

At the farming dinners of the earlier period referred to patriotic and sentimental songs were most favoured after the hunting ones, and, strange to say, there was generally a fair sprinkling of sea-songs, but you rarely heard a real good old country-side ballad, telling of the common incidents, the sunshine and the storm, of rural life. You had to go elsewhere for these, as Mr. Cecil Sharp, who has done so much to rescue 


\section{FIFTY YEARS OF A SHOWMAN'S LIFE}

from oblivion many striking and graphic outpourings of the minds of the people, could tell us. It was in the village hostelry and at the harvest homes that you heard "The Vly among the Turmuts," "God Bless the Puir Sheep," "A Gossipin' Wife goes Gaddin' Aboot," and, in the West, "When I went a-coortin" to Taunton Deane." In England, as in other countries, it has been the people, living by the sweat of their brows, who have preserved for us the melody and the poetry of the country-side, as represented by the folk-song, born and bred of the soil. What could be more characteristic of rural experiences than the chorus, as it used to be sung in Wiltshire :

\section{"The vly be on the turmuts, The vly be on the turmuts. \\ It be arl me eye for oi to try \\ To kip they arf the turmuts."}

I did, however, once hear a farmer sing an excellent country-side song, which I have tried in vain to run to earth since. Its burden was "Brave boys, though I'm ragged I'm true," and was as unexceptionable in its sentiment as the air was in its suitability to the words, whose very spirit, compounded of humour and pathos, it breathed. It was sung with just the unctuous heartiness appropriate to the theme, which greatly helped its effect. The singer promised me a copy of it, but it never reached me, and, as he must have departed this earth long ago, for he was fairly old when, in the 'sixties, I heard him sing it, he is not likely to send it to me now.

On many occasions $I$ had experience of the "staying powers" of farmers when they seriously 
"IT WAS MY FATHER'S CUSTOM"

settled down to do justice to a good dinner, and I did my best-I believe not unsuccessfully - to keep pace with them. My father was a good trencher-man, and he had two other qualifications which carried weight in agricultural circles-he was an accomplished smoker and an exceptionally good singer. Farmers, in the matter of social observances, as well as in many other things, are extremely conservative, and it was soon brought home to me that I must follow my father's example in both these respects if I were to occupy that pleasantly familiar footing on which an official desires to find himself with regard to those whom he serves. So I brought both the accomplishments in question to bear, though I must admit I was but a poor second to my father as a practitioner of either of them. In those days and in that company cigarettes had no vogue whatever, and the briar-pipe had not made much headway, tobacco being enjoyed through the medium of either a long clay or a cigar, with, of course, a dip into the handed-round snuff-box. I selected the long clay simply because it kept the flavour of tobacco, which I disliked, further away from my mouth than was the case with a cigar. When I was strong enough to hold my own without such an accessory to popularity, I abandoned it. I have no conscientious objections whatever to smoking, and can stand any amount of it when others round me are enjoying it, so long as I am not expected to be an active participator. As to my vocalization, it may be said to have possessed the negative quality of not provoking listeners to hostile demonstrations. 


\section{FIFTY YEARS OF A SHOWMAN'S LIFE}

The crowning beverage of an agricultural feast, when the wines, having fulfilled their mission, had been finally disposed of, was at this time lemonade and gin. Its popularity was on one occasion during the early days of my association with the Oxfordshire Agricultural Society. so forcibly brought home to me that the recollection of it is still fresh in my mind after this long lapse of years. It was the custom on the night previous to the opening-day of the show for the stewards and judges to meet together round the festive board for the enjoyment of a real good, old-fashioned, substantial dinner. For the ordering of this I was responsible, the cost being defrayed by the Society, and very properly, as it was but a small acknowledgment of an immense amount of voluntary work. With my knowledge of those, who would partake of it, I was well aware that both meat and drink must be on a generous scale, and my anxiety, having regard for the Society's funds, was to supply just sufficient, without overdoing it, and yet to afford no ground for complaint. On this particular occasion, having been very busy all day in the show yard, I had had no time before dinner was served to inspect the bedroom reserved for me at the hotel, which was our headquarters and the local of the dinner. In misplaced confidence, I contented myself therefore with an assurance from the landlord that a comfortable apartment was reserved for me, and dismissed the matter from my mind till bedtime.

Being unusually tired after a long spell of hard work and anxious to be fresh for the next day's 


\section{A HAVEN OF REST ?}

fray, I did not follow my usual custom and sit out the function, which bid fair to be a late one, to the bitter end. Leaving a goodly company, full of that genial sociality which loses count of time, at a moment when I could slip away unobserved, I made tracks for the longed-for haven of rest. On inquiring for my room, nobody seemed to know where it was, but the landlord assured me that he was just having it prepared for me. Conceive my horror when I found that the chamber wherein I was to woo the good offices of nature's sweet restorer was provided by the cutting off with a couple of screens of a corner of the banquet-hall I had just left. The room originally assigned to me had, through a mistake of the booking-clerk, been re-let to some one else who was already in possession. In vain I stormed and protested and demanded different quarters; it was all of no avail, for every other nook and corner of the hotel and every piece of furniture on which it was possible for a mortal to recline had been already appropriated. So, as it was Hobson's choice, and a precious bad one to boot, I had no alternative but to accept it, earnestly trusting that the revellers might soon be as tired as I was and yearn for their several couches. Vain hope! Conviviality reigned supreme, and found its vent in inexhaustible vocal harmony, stimulated by a refresher, the name of which was burnt into my memory for all time by constant repetition.

During the long watches of that anything-butsilent night, it was over and over again impressed upon me that the beverage par excellence with 


\section{FIFTY YEARS OF A SHOWMAN'S LIFE}

which agriculturists of those parts most delighted to crown a night's festivity was nothing more nor less than lemonade and gin. The intervals between toast and song were filled up with monotonous iteration by calls for this seductive liquor, which not only possessed the power of bidding dull care begone, but also seemed to have the effect attributed to the waters of Lethe of steeping the mind in forgetfulness. This may, perhaps, account for the fact that $I$ had to listen to three separate and distinct renderings of "The Englishman," the full-bodied chorus of which seemed to be endowed with additional strength and vitality upon each repetition. Every man at that festive board had, in country parlance, got his sittingbreeches on, and seemed determined, if possible, to wear them out that night. Unhappily, there was no Licensing Act or Defence of the Realm Regulations in those far-off days to curtail the proceedings. But even the longest day or night must come to an end at last, though day had dawned before the last note of the last song had died upon the air and the last lemonade and gin had been quaffed. By that time my many tossings and turnings had brought my nerves to such a condition of wakefulness that any attempt at repose was out of the question; so I made the best of a bad job and got up.

The evening's diversion bore the morning's reflection very well in the case of the revellers, who all turned up in good time, and as they put it as "fresh as paint," and with not so much as a single trace of ill-effects from the divers liquors, including the many toppers, they had disposed 


\section{SEEING IS BELIEVING}

of. This certainly spoke well for the accommodating powers of their constitutions and for the quality of the drinks they had absorbed. I don't know what they drink now under similar circumstances in Oxfordshire, or whether their staying powers are equal to what they were. But I do know that never since then have I ever taken the word of any hotel proprietor that a comfortable apartment has been reserved for me without ocular demonstration, long before I wanted to avail myself of the accommodation, that it was well out of earshot of any banqueting-hall. 


\section{CHAPTER VII}

"A Fine Old English Gentleman"-A Political Meteor-A Surprise Visit.

T F, as I have already pointed out, modern-day developments have deprived the farmer of

1 some of those characteristics which very clearly differentiated him from the dweller in towns, the same influences have not left the squire untouched. The steady-going, slow-moving embodiment of that sterling stubbornness which stood England in such good stead during the stress and strain of the Napoleonic Wars, and which was the stand-by of the elder Pitt, as well as the sheet-anchor of the country-side, has wellnigh passed out of ken. One of the best specimens of the old squirearchy I ever met was Joseph Warner Henley, who, for many years, represented Oxfordshire in Parliament, and was President of the Board of Trade in Lord Derby's two administrations. He was the beau-ideal of a country gentleman of the old school-the Chairman of Quarter Sessions, par excellence -in manners, dress, and everything else. With a sterling independence admitting of no deflection, there was combined a shrewdness and a prudence which accounted for and justified the position he held in the minds of rich and poor alike. He had the rare gift of 66 


\section{"A FINE OLD ENGLISH GENILEMAN"}

being able to convey what he had to say in terms whose force was only equalled by their terseness.

I still preserve some of the letters I had from him for the sake of their quaintly-turned phrases. He it was who brought into use, among many other expressions, embodying much in the fewest words, the term "ugly rush," which he applied to the influx of new voters under the proposed Derby Reform Bill. I can see him now, in a tail-coat, buff waistcoat, black stock and collar, the latter Gladstonian in size, girding on his sword, as "a Knight of the Shire," on the hustings, after one of his elections to Parliament. He had only to fight for his seat once, when he was returned at the top of the poll, and yet he sat for his county for nearly forty years. I have seen him enter the county town on nomination day, escorted by a most imposing blue-rosetted procession of tenantry on horseback, and preceded by the display of banners and flags, which were such characteristic features in the elections of those days. I have joined heartily, too, in the chorus of "The Fine Old English Gentleman," which was often part of the greeting he received when he rose at agricultural dinners to respond to the toast of "The County Members." He was a good supporter of the old Oxfordshire Agricultural Society, whose President he was for many years, and that accounts for my being brought into contact with him.

He was born so far back as 1793, and lived till 1884, so that he was a connecting link in agriculture, as well as in other matters, between a past and present which, measured by the changes 


\section{FIFTY YEARS OF A SHOWMAN'S LIFE}

embraced in the interval, is far more distant than the years denote. I have always had some pleasure in remembering that I was brought into personal communication with one so typical of a time now dead and buried. The present age could not produce his exact counterpart-the conditions of life nowadays do not admit of itand so I feel very much as if I had held converse with the denizen of a world other than the one in which $I$ live.

At a later date, I had the fortune to see something of one who loomed large upon the political stage for awhile, and who was the very antipodes, in temperament, of the level-headed, placidminded embodiment of all that was stable, to whom I have just referred. The Oxfordshire Agricultural Society wanted to hold its 1879 show in Blenheim Park, and it was thought that the best way to bring this about was to invite the rising hope of the Marlborough family, Lord Randolph Churchill, to accept the Presidency of the Society, which he consented to do, and it was as secretary that I was brought into communication with his lordship. The latter had a somewhat chequered University career-that is to say, he did well in the schools, but was not infrequently in revolt against authority, which last was probably due to his mental activity needing a vent. He was returned to Parliament for the family borough of Woodstock-which had been represented by his father before he succeeded to the dukedomin 1874, but, up to the time of his election to the presidency in question, had not shown any particular aptitude as a speaker, or any special 


\section{LORD RANDOLPH CHURCHILL}

interest in agriculture. Consequently, those who had promoted his election to the Presidency were reproached by some for putting forward so young a man, and one without much distinctive claim. But they reckoned without a knowledge of that painstaking determination to master whatever subject he took in hand, which, throughout his career, was Lord Randolph's distinguishing characteristic, and, in after years, enabled him to speak with so much authority upon so many different questions.

In those days, it was customary to have a big dinner in connection with the Annual Show of the County Society, when the county and any neighbouring borough members were expected to attend. and give an account of their stewardship. The speeches were supposed to be more agricultural than political, but orators sailed uncommonly near the wind with respect to the latter, and a speaker had a patient hearing so long as he wasn't a bore, or too lengthy. If he suffered from either complaint, his hearers had a remedy, i.e., a general shuffling of feet and clattering of plates, which even the best pair of lungs was not proof against in the long run, as the storm gathered force. At such a dinner Lord Randolph took the chair, amid considerable misgivings on the part of others as to how he would acquit himself. To the gratified astonishment of the meeting, he made an admirable speech, in responding to the toast of the Society, and showed a mastery of agricultural problems which took even those who knew him best by surprise. The Marlborough farm-tenants were particularly pleased, because some of the sentiments 


\section{FIFTY YEARS OF A SHOWMAN'S LIFE}

he then expressed, respecting the relationship that should exist between landlord and tenant, were very much of a revelation to them, and certainly not what they had been accustomed to. I do not think this instance of his capacity, at this early stage of his career, to grasp and utilize information outside his ordinary sphere of knowledge is generally known, but it has always dwelt in my memory as something very remarkable. How highly this faculty was developed in after years, the permanent officials at the India and Inland Revenue Offices could testify. I afterwards saw something of his lordship when I was editing the Oxford Journal, and found him, as most others did, a very attractive personality.

I remember my last interview with him. We were in the throes of a General Election, and the campaign opened when he was out of England. He hurried home to look after his seat at Woodstock, where he had a somewhat formidable opponent in the person of the Hon. J. Brodrick, who, curiously enough, was a Fellow, and in after years was Head; of the very College, viz., Merton, to which Lord Randolph belonged in his undergraduate days. Easter fell in the midst of the turmoil, and, so far as Oxford was concerned, both sides suspended operations from the Thursday before Easter until after Easter Monday. This brief cessation and strain did not, however, apply to newspapers, and so, after I had rendered my dues to the church on Good Friday, "I held a candle to" some one else, by going to my office, where I felt I should be able to make some headway against the stream of work, without fear of 


\section{A POLITICAL METEOR}

interruption. But a meteor, political or otherwise, does not usually announce its approach beforehand. Hearing some commotion in the street outside, I went to the first floor window of my office, and on looking out beheld a somewhat striking equipage decorated with pink ribbons, and with a particularly long streamer attached to the coachman's whip. Gracefully reclining in the open carriage, enjoying a cigar, was Lord Randolph. Marvelling what could possess him to travel from Woodstock-about eight miles off-in this election state on Good Friday, I returned to my desk.

Presently there came a gentle tap, tap, tapping at the street door. I thought the outside world might leave me alone on this day at any rate, but, being the only occupant of the premises, I felt I had better answer the summons. Having done so, I found myself face to face with Lord Randolph, and the inquiry: "Please, may I come in ?" Then it transpired that, as Good Friday was a dies non, so far as meetings and canvassing were concerned, his lordship thought he might as well spend his time in finding out all he could with respect to his electoral chances. From my intercourse with farmers, I happened to know that his seat had never been in more jeopardy than at that moment, not on account of anything for which he was responsible, but solely because of certain grievances of some of the tenants on the Blenheim estates. I told him what I knew, and urged that some steps should be taken at once to counteract the influence that was at work. He expressed his intention to do what was necessary, and he met my forebodings with the assurance 


\section{FIFTY YEARS OF A SHOWMAN'S LIFE}

that he had the time, before the poll, to put things straight, and that he meant to do this and to win, though, he admitted, with not much to spare. He did win by sixty votes, which was the smallest majority he ever polled. The incident in question illustrates the pertinacity with which he would run any information he wanted to earth, and his promptness of action in utilizing it afterwards, for, as I have reason to know, he took a very strong course, and saved his seat thereby.

Lord Randolph, undoubtedly, derived his main characteristics, his brilliancy, his dash and his daring, from his mother, who was a Londonderry, and who was generally regarded as the governing factor in the Marlborough household. His father was a man of lofty ideals in the discharge of the duties pertaining to his station, and, whether as Lord-Lieutenant of Ireland, or of his native county, his nobility of character was equal to that of his rank. The embodiment of gentle courtesy, he maintained withal a dignity which no one could set at naught. I have every reason to hold him in grateful recollection, for when I turned a longing eye to the West he was one of those who did much to help me on my way thither, and with a kindliness which left me much his debtor.

The nature of my work at this time brought me into contact with many shining lights of the agricultural world, of whom I have pleasant recollections. As, however, particulars of incidents rather than of persons best serve the purpose of these recollections, I have limited myself to recalling but a few of the latter as illustrative types. 


\section{CHAPTER VIII}

"As Merry as a Whitsun Morris Dance"-The Butleigh Revel"Stop Thief "-The Story of a Watcb.

7 HE friendly and sociable footing on which everybody met at the festive gatherings to which I have referred afforded favourable opportunities for the acquisition of reminiscences of old country-life. Farmers are not great talkers, and, speaking generally, err, if anything, on the side of reticence, but a moderate circulation of the wine-cup engendered a disposition favourable to the exchange of confidences. I remember once sitting next to an old farmer at one of these dinners, who, as an instance of his youthful sportiveness, told me that when he was a young man he and a goodly number of compatriots used to spend a fortnight at Whitsuntide making a round of the various villages as Morris dancers. This seemed to bring one nearer the days when our country earned the title of "Merrie England," for I had not previously pictured the sons of the farmers so frolicsome as this. As a boy I have often enjoyed the performances of a peasant troupe of Morris dancers, who annually visited the city in which I lived. They were usually eight in number, and were attired in white shirts, white trousers, and tall black hats, with plenty 


\section{FIFTY YEARS OF A SHOWMAN'S LIFE}

of gay ribbons at all points, and many little bells which jingled with the movements of the dance. They were accompanied by a fiddler and by a "Squire" or "Fool"-he answered to both designations - who was more elaborately costumed than the rest, and more after the fashion of a jester. He carried a stick with a calf's tail at one end and an inflated bladder at the other, with which he kept a clear space for the dancers, bestowing hearty thwacks upon the backs and sides of any among the crowd who encroached too much; he also collected the bystanders' contributions in a tin box. Among the dances performed was one with sticks, each man striking the stick of the opposite dancer, keeping time to the music, something after the manner of a melodramatic backsword combat, whilst there were other dances in which handkerchiefs were prominent features.

Not very long ago I had a pleasant reminder from my native county that one of the dancers of my young days was still on the move, and able to show the rising generation the true art of Morris dancing, as handed down from generation to generation. Years ago, a celebrated troupe of Morris dancers hailed from Headington, near Oxford, among them being William Trafford, who has danced in his troupe for more than sixty years. As he is over eighty years of age, he must have begun his practice of the art somewhat early in life. His fame had travelled to London, and not long since he was asked to go there in order to show a modern Guild of Morris dancers what the real, genuine article was like. As the old 


\section{AN OLD MORRIS DANCER}

man had never before been to the Metropolis, special arrangements were made to ensure his safe arrival at his destination, and he had a bodyguard of half a dozen to this end. Somehow" or other, however, they managed to get cut off from him, or he from them, on the Underground Railway. When the bodyguard arrived at their destination and reported their loss, there were dire forebodings as to whether the dancer would ever be recovered, in view of the difficulties country-side folk experience when travelling under, what is to them, somewhat unusual conditions. The hon. secretary of the Guild remarked that once she mislaid a deputation of forty-two miners on the same railway, and that many hours elapsed before their whereabouts could be ascertained.

A search party was, therefore, despatched for Mr. Trafford, and by great good fortune they lighted upon him shortly before 10 p.m., and brought him in triumph to the hall, to the great relief of everybody. Mr. Trafford, whose advent was loudly cheered, did not appear to be any the worse for his experience, which he seemed to regard as the natural consequence of leaving his native village for foreign parts. He was unable to furnish exact information as to the number of times he had completed the circle, but he had, on the whole, enjoyed the journey, though he did not consider the scenery of the Underground equal to that of his native county, being somewhat too monotonous for genuine lovers of the picturesque. Happily, his adventures had not in any way diminished either his ardour or his activity, as was very evident from the way in which he threw 


\section{FIFTY YEARS OF A SHOWMAN'S LIFE}

himself into the task of showing how they used to dance in his parts "a-many years ago."

The revival of late of such old-time relics of the country-side, as the Morris and other country dances, the singing games and folk-songs, performed by children, is an excellent sign of the times, provided it is practised in moderation and does not usurp the place of more important matters. It is not only artistic and healthful, but it stimulates a sense of rhythm, always worth cultivating in the young, and an innocent joyousness which we all desire to associate with childhood. It is so full of happy possibilities that it deserves all the encouragement we can bestow upon it, if it be regarded as a recreation pure and simple and not allowed to usurp the place of more serious studies.

It is remarkable how much of the dramatic instinct is to be found among those living very much out of the hurly-burly of life on the hillsides and among the hedgerows. Those who have looked for it have found it, as has been shown by the success of the Dorset and other country plays of recent times. A most striking example was furnished a few years since in Somerset by the "Butleigh Revel." Here you had a whole village, with the Squire at its head, giving itself up, heart and soul, for a long period - for it involved months of preparation and rehearsal-to what the old-fashioned term describes as "play-acting." Those who were fortunate enough to witness it-and it attracted some thousands of people-went away deeply impressed with the extraordinary spirit and evident enjoyment with which the villagers carried 


\section{THE BUTLEIGH REVEL}

out their self-imposed task, and the keenly appreciative way in which they grasped and acted upon what was expected of them. With scarcely an exception, every man, woman, and child in the little community bore a part, and, while the performance was in progress, in the Court grounds, even Goldsmith's village was not more deserted. It is something to feel that even now rural England can be "Merrie" on occasion.

I cannot forbear giving an illustration of the realistic way in which the Butleigh Revel was carried out. One of the principal characters was sustained by the Squire himself-Mr. R. Neville Grenvile, of Butleigh Court-who, while one of the most versatile and cultivated of men, has a perfect mastery of the Somerset dialect, "as she is spoke" by those indigenous to the soil. The part he had to play afforded full scope for a display of this gift of the vernacular to the unbounded pleasure of the audience. Travelling home by rail after delighting in this, I got into conversation with a lady who had also been at the Revel. She had enjoyed it very much, but "Oh," she said, in a tone of the deepest regret, "what a sad thing it is that the Squire of the place should be so uncultivated and illiterate; why he speaks no better than an ordinary labourer." She could hardly credit it when I told her that he was an Old Etonian and a Cambridge M.A., and that in ordinary life I knew of no one whose pronunciation was more refined or more beyond criticism. But it was a wonderful tribute to his ability to "hold the mirror up to nature." 


\section{FIF'I'Y YEARS OF A SHOWMAN'S LIFE}

I have called attention to various changes occurring among the agricultural community in my own time, and this applies not only to manner, and customs, but to costumes also. Gone are the tail coat, the buff waistcoat, the high collars and satin stock and beaver hat of the Squire; the breeches and gaiters, the long coat with great gaping pockets, and the broad-brimmed hat of the farmer; the worsted stockings and breeches, the smock-frock, the red-kerchief and the billy-cock hat of the labourer. Yet I remember when all these were de rigueur. They are impressed upon my memory, because, as a child, I lived at Oxford in a house overlooking a great central thoroughfare, Carfax, where four ways met. In this open space on Saturdays, year in and year out, warm or cold, rain or shine, the farmers handed their samples to the dealers who bargained with them, while I watched from a window and wondered what all those little bags contained; and it was also a gathering-point for every other section of agricultural life.

I particularly remember the great gaping pockets and a circumstance connected therewith, which interested me very much when my father narrated it. He had been over to a country town, through which the late Queen Victoria was passing, and this attracted a large concourse of persons from the surrounding country districts as well as a sprinkling of gentry with predatory instincts from Birmingham and elsewhere, who deemed it a good opportunity to ply their calling. My father, sight-seeing like the rest, suddenly felt a tug at his waistcoat pocket, saw his watch 
chain dangling, and a man making off. He at once raised a cry of "Stop thief!" which was taken up, and soon the crowd were in hot pursuit of the suspected party, who was decidedly fleet of foot. However, he was pulled up at last, and the watch demanded of him. He indignantly disclaimed any knowledge of it, and told his pursuers to search him if they doubted his word. Searched he was, and no watch was found on him, which puzzled my father amazingly, because he had spotted the thief directly he had felt the tug. However, there was nothing for which the man could be detained, so he had to be set free. An hour or so afterwards an old farmer, in a state of much perplexity, having heard of the lost watch, sought an interview with my father, and, to the latter's astonishment, produced the missing timepiece from his pocket. On my father identifying it, the farmer said: "I hope you don't think I stole it, though I don't know how in the world I got it. All I can say is, I found it in my pocket." The explanation was not far to seek. The thief, finding himself hotly pursued, thought the best thing he could do was to disencumber himself of such a damning piece of evidence as the filched article. The pocket invitingly gaped for it, so, as he ran past the farmer, he took advantage of this fortuitous circumstance, and dropped the watch into this convenient receptacle. My father was only too pleased to get back his property and to assure the restorer of it that no one could possibly suspect him of any complicity in its abduction.

The after-fate of this watch seemed to indicate 


\section{FIFTY YEARS OF A SHOWMAN'S LIFE}

that it had a sort of hankering after bad company. My father carried it about with him for fifteen years after the incident just narrated, and then finally lost it within a few yards of his own house. Proceedings had been taken at Petty Sessions against a party of prize-fighters for a breach of the peace, and a number of their friends came to Court with them to support them by their presence. The principals were heavily fined, and there was a good deal of commotion when they were brought back to the police station. My father went out to see what was the matter, and on his return found his watch chain loosely dangling, but could not discover his watch at the end of it. $\mathrm{He}$ promptly gave information of his loss to the police, who informed him that he was the third gentleman who had made a similar report within the last five minutes. It transpired that the pugilists, having every reason to believe that they would be convicted, brought down with them a contingent of professional pickpockets, whose business it was to procure the amount of the fines by abstracting the value from the pockets of the general public. This time the watch permanently substantiated a claim to be "a good goer," for it went once and for all, so far as my father was concerned.

There is a sequel to this story which, perhaps, ought to be told. My father did not like losing his watch, and declared he would not have another good one. So he bought quite a cheap timepiece, which came into my hands at his death. Having a watch of my own, I did not use my father's, but simply let it rest among other 80 


\section{'THE FLIGH'T OF TIME}

mementoes of him. I had had my own watch about as long as my father had had the one of which he was relieved, when in my capacity as Mayor of Bath, I was invited by the Lord Mayor of Bristol to join him in receiving the present King and Queen on their visit to that city. As I stepped out of the railway carriage at Bath on returning home, I put my hand to my watch pocket in order to learn the time. Strange to say, my hand grasped nothing, my pocket being as empty as my father's was on the occasion to which I have just referred. I felt for my chain, but that had no more substantiality than my watch. And then I was forced to the humiliating conclusion that I had been no more wideawake than my progenitor was when he allowed a common thief to despoil him. History had once again repeated itself, but had gone one better in my case by depriving me of my chain as well as my watch. I remembered that, when waiting at Bristol Railway Station for my train, there was a sudden stampede and some one cannoned against me, and I suppose that it was then the abduction was accomplished. It must have been very cleverly done, for I never felt the tug. Sadly I betook myself to the Bath Police Station in order to request our watch dogs to communicate with the Bristol constabulary upon the subject, and, having done this, resolved that I would take particular care to keep all knowledge of the incident securely locked within my own breast.

I had sufficient acquaintance with the world and its ways to realize that no one ever gets any real sympathy on losing his watch at the hands 


\section{FIFTY YEARS OF A SHOWMAN'S LIFE}

of a common pickpocket. Those who have not suffered a similar deprivation simply pity the loser for being such a fool as to let anybody get the better of him in this way. Having then occupied myself at home for an hour or so, I sallied forth looking as little as possible like any one who has been dispossessed of anything. Only a few steps from my own door I met a citizen with whom I had a slight acquaintance, who at once pulled me up in order to offer his condolences and to inquire whether it was money, jewellery, or plate that the rogues got off with and how they managed to obtain entrance. Astonished and dismayed at the escape of my secret and the proportions it had assumed, I was obliged, in self-defence, to admit the truth of the matter to the manifest disappointment of my interrogator, who thought that nothing less than a burglary was worthy to be associated with the position of a chief magistrate. The mere snatching of a timepiece was such a low, commonplace offence that it was not maintaining the dignity of the office to allow it to occur. I could see that this was the trend of his thoughts, so I contented myself with asking him how in the world he knew that anything whatever was missing, and, for my consolation, he assured me it was "the talk of the town." which I too soon discovered was literally true. Marvelling greatly how this was brought about, I found my answer at the top of the street, where a newspaper contents bill bore but this one inscription, in letters bold enough to enable him who runs to read, "The Mayor of Bath robbed." 


\section{A STANDING JOKE}

The news of the nature of the loss was a perfect godsend to all who had any pretensions to jocularity or had any character for humour to keep up, for the display of which it afforded unlimited opportunities; sympathy, as I knew it would be, was altogether out of the question. Reference to it cropped up, quite spontaneouslike, in all kinds of unexpected places, as a means of providing "innocent merriment," and I had to give many assurances that it was not the mayoral chain that was missing. At a Chamber of Commerce banquet I was called upon to propose the health of the Lord Mayor of Bristol, who was present, and, of course, had to trot out all the nice things I could think of about the notable city over whose destinies his lordship presided. As I paused for a moment after a flowery tribute to its manifold attractions, the late Sir George Reid, the then High Commissioner for Australia, and afterwards M.P. for a Metropolitan constituency, promply filled up the gap by a gentle inquiry, accompanied by that mirth-provoking chuckle which gave special point to his humorous sallies, as to whether I had "ever lost anything at Bristol ?" The roar of appreciation which followed was a tribute to the success of his interpellation, and all I could reply was that time passed so quickly at Bristol that there one never felt the loss of it, which was strictly true, as I discovered nothing till I reached Bath.

This joke lasted until the termination of my term of office, when in my valedictory speech on laying down the Mayoralty I expressed my thanks to all and sundry, and especially to Jordan, the 


\section{FIFTY YEARS OF A SHOWMAN'S LIFE}

Mayor's attendant, who, with so much fatherly and kindly care, had protected my person and my interests during the past year. At this a councillor innocently inquired, "Where was he at Bristol ?" Then it was I got a bit of my own back, for I was able to reply that he couldn't be always "on the watch." My father's cheap watch, after its long spell of over forty years' inactivity, came once more into use, but not permanently, which leads me to admit that the thief did not do me such a bad turn after all, inasmuch as an admiring relative pressed upon my acceptance a chain worth a good deal more than the one I had lost, and, later on, the President of a Society with which I am intimately connected, under an impression that I had been of some help to him during his term of office, bestowed upon me a very fine, gold watch - the one I lost was only silver-as a little memento of what had been to me a very happy association. Verily, the world is full of compensations ! 


\section{CHAPTER IX}

A Clouded Horizon-Farmers' Trials-The Revolt of the Labourers-The Maligned Landowner.

M

ANY of the earlier recollections here set down were gathered during the cheery times of agriculture, when things were, more or less, booming. The discovery of gold in California in 1848 and in Australia in the early 'fifties was good for agriculture and commerce, and then the Crimean War sent prices up, and the American War helped to keep them there.

But there was a bad time coming, and one of the first of a succession of misfortunes was the importation from Russia of that terrible disease, the rinderpest, or cattle plague. I have a vivid remembrance of its devastating effect upon agriculture. It meant absolute ruination to hundreds of farmers, and the sufferings of their animals were pitiable in the extreme. It broke out in this country in 1865, and it was not until 1867 that its ravages were stayed. Fully half a million head of cattle died, at a direct cost of at least $£ 5,000,000$, apart from the indirect drain upon resources by the general dislocation of all trade in beasts, for markets, fairs, and shows had to be suspended. For many years and until his death, I enjoyed the friendship of Professor (in later years, Sir George) Brown, C.B., 


\section{FIFTY YEARS OF A SHOWMAN'S LIFE}

chief of the Veterinary Department of the Privy Council and afterwards of the Board of Agriculture, the one man whose courage did more than anything else to stem the calamitous tide. When called in to advise the Government, he said: "Give me a free hand and I can stamp it out." His remedy was "Slaughter, slaughter, slaughter!" He was given full licence to carry out his specific, and he fulfilled his undertaking. He was one of the most imperturbable of men, the very personification of that coolness and confidence which even an earthquake would never disturb. He had a wonderful store of worldly wisdom, rendered all the more effective when drawn upon by a vein of the dryest of dry humour and an impassiveness of countenance which even the Sphinx might envy. He was for many years, and until his death, the Bath and West Society's veterinary inspector, so that I had full opportunity of knowing and appreciating his striking characteristics. He was the apostle of prohibition of live imports from foreign countries, and the legislation which has followed upon the representations of himself and other practical authorities has been of incalculable benefit to this country. Cattle plague, foot-andmouth disease, pleuro-pneumonia, rabies, etc., could never have been practically stamped out and kept out in any other way. How well the battle of prohibition was fought in Parliament and the country by such men as Clare Sewell Read, Tom Duckham, and Albert Pell-all of whom I had the pleasure of knowing, for we foregathered at the Farmers' Club and elsewhere -will never be forgotten by those who realized 


\section{A POLICY OF FREE TRADE IN DISEASE}

how much there was at stake. Yet I remember how strongly these protective measures were opposed by many of the townsfolk.

I took part in an Oxford election when, in the interest of the late Sir William Harcourt, one of the sitting members, there was a procession through the streets of cattle placarded with appeals to vote against the wicked Tories, who wanted to keep good stock out of the country, and thereby raise the price of food to the working man. I did my best then to combat such a delusion, though unsuccessfully, so far as the result of that election was concerned. But I have lived to see a Liberal Government firmly refusing to deviate a hair's breadth from a course, the denouncing of which helped them into office in 1881. At intervals, of late years, Parliament has been urged to remove the restrictions upon the importation into this country of live animals from abroad. My mission, however, being to furnish experiences rather than to discuss matters of agricultural policy, I will not recapitulate here the various arguments which have induced the Government, with the backing of all the leading agricultural organizations, apart from mere trading ones, of the country, to stand to its guns in this matter. But I may say that I believe that if the agitators for the repeal of the restrictions had as vivid a remembrance as I have of the greatest single calamity that ever befel British agriculture they would pause before they urged the throwing open of our ports as proposed.

With the exception of the cattle plague visitation, agriculture was fairly prosperous till 


\section{FIFTY YEARS OF A SHOWMAN'S LIFE}

about the middle of the 'seventies, and then misfortunes came thick and fast. Everything and everybody seemed to be leagued against the British farmer; Providence even, as represented by the weather, included. He was told of all kinds of panaceas, most of them quite impracticable, by hosts of people who knew as much about farming as they did of ballooning. He was urged by politicians and others to give up corngrowing altogether, and go in for jam-making, tobacco-raising, fruit-growing, poultry-farming, and heaven knows what else, and was reproached for his obstinacy in not changing almost in a minute all the habits and traditions of a lifetime in order to take up matters of which he had no previous experience. I have unearthed the following lines, written at this time, which pretty accurately represent the disabilities under which the agriculturist of the period felt he was suffering.

" $\mathrm{Oh}$, everything's against us, and we oannot get relief.

The Yankees undersell us with their corn and frozen beef.

And now the latest remedy, which sounds much like a joke, Is 'go in for tobacco,' but that's bound to end in smoke.

It's all up with farming, and we're all ruined quite,

The weather's nearly always wrong, the prices never right;

The labourer we have to pay more wages, or he strikes, And now he's got a vote-what's more, he votes which way he likes. John Barleycorn's against us, too, like all the rest, oh, dear !

For when they took the tax off malt they clapt it on the beer.

And when we make good butter, then the trade for that they squash, For grocers push their ' margarine,' their 'butterine,' and 'bosh.'

We're told by Fleet Street journalists and city denizens

The road to fortune we should find in breeding cocks and hens.

But though we've borne all this and more, and stood it like a lamb; 'The last straw' was when Gladstone said-'Pin all your faith to jam." " 


\section{THE LABOURERS' REVOLT}

The farmers certainly were in hard case, and all their previous upbringing militated against their suddenly adapting themselves to altered circumstances. On the very threshold, too, of other misfortunes they had to meet what tried their patience and their temper more than all, viz., the revolt of their labourers. It was in 1872 that Joseph Arch carried his fiery cross through the counties and started his Labourers' Union. Although wages had from 1850 onwards gradually advanced, it must be admitted they had not kept pace with the rise in prices, and herein was to be found some justification for the effort made to redress the balance. But there was less justification for the methods employed to this end. No distinction was drawn between the good and the bad master, and the most virulent and incendiary language was used of all alike. The farmers were attacked from many platforms and not a few pulpits, and the Press joined in the hue and cry. This led to my taking a small hand in the game, for the farmers asked me to champion their cause in the Press and elsewhere, and to help them organize a resistance, which resulted, at any rate, in the public learning that there were two sides to this as to many other questions. The labourers, headed by self-constituted leaders, walked about in procession through the country towns, wearing the blue ribbon, which was the badge of the Union, and was to the farmer as the red rag to the bull, and singing about the land, honestly believing that they were coming into possession of it. 


\section{FIFTY YEARS OF A SHOWMAN'S LIFE}

I remember my main difficulty with the farmers was in persuading them that the most politic course was to allow the other side to have a monopoly of the strong language; they did so want to pour out their souls in response. After all, the Union was little more than a nine days' wonder, so far as its activity was concerned. Outside causes, with which the Union had no connection, made themselves felt, and had more to do with the ultimate rate of wages than all the efforts of democratic agitation. The fact is, the agricultural labourer is in an entirely different position to any other worker. If he withholds his services to his employer at the bidding of a society and not at his individual discretion, he can work incalculable injury at such critical periods as seed-time and harvest, and it is impossible to lay down a hard and fast rule that he shall only work so many hours a day and at stated times. Such fixed rules are ill-suited to the changing conditions of seasons and of crops. Besides this, there are many times in the year when work on the land is neither urgent nor indispensable, and then the labourer is often kept on whether his time is fully employed or not. The Union struck at the old relationship, in which there was give and take on both sides, between masters and men, and a great deal of bad feeling was engendered. The fuller effects of this were manifest when, a little later on, the great depression in agriculture set in, and both sides felt the pinch of bad times.

At the same time it is very clear that when 


\section{THE FARMERS' DEFENDER}

the rural labourer returns from the war he will have to receive fuller consideration in the future than he has had in the past if he is to be retained on the land. It will be not merely a question of higher wages, but of better conditions generally, especially with regard to housing. This is much too big a question to enter upon in these pages, but, to put the matter shortly, those masters who have not sufficiently realized their responsibilities towards the workers will have to come into line with those-and, thank Heaven, there are many such!-who have had a better conception of their duty in this respect. The war has done a good deal to remodel opinions, Parliamentary and otherwise, concerning the British farmer, and now that Mr. Lloyd George has taken up the cudgels on his behalf and delivered a splendid defence of him, as an answer to his detractors, one need not pay much attention to what the smaller fry may say and think.

Among other excellent developments arising out of the war is the instituting by the Board of Agriculture of a general inquiry throughout England and Wales into the present conditions of employment in agriculture. This will put the Agricultural Wages Board into possession of full and definite information with regard to present rates of wages for time and piecework, benefits and advantages given as supplementary to cash wages, hours of labour, rents and tenure of cottages, and economic condition of farm workers generally. It will also help to clear up many disputed points, and, by placing the Board in possession of detailed information as to the 


\section{FIFTY YEARS OF A SHOWMAN'S LIFE}

labourer's present position, will materially assist it in arriving at conclusions affecting his future remuneration and the general conditions under which he should pursue his avocation. A consideration of the subject in a broad-minded spirit which will take cognizance of the varying circumstances, as to cultivation, tenure, etc., prevailing in various parts of the country, should result in good to all concerned.

It will, however, have to be borne in mind that if the farmer has to pay higher wages, whilst his bills for feeding-stuffs and many other essentials of his calling are on the up grade, he will want more consideration from the State than he has hitherto received.

Many a time and oft the landowners have been held up as the embodiment of all that is grasping and unprincipled by those who, with no personal experience of them, have not hesitated to traduce them for political purposes. Yet it may be truly said that there is no body of men in the world who hold a higher place in the estimation of those who are brought into immediate contact with them than the landed gentry of England. No men, speaking generally, have more fully recognized their duties and responsibilities to their country, or have given more liberally of their time and money, for the promotion of its best interests, and in these latter days they have parted with their very lifeblood on the battlefield. In the dark days of agricultural depression, it was the exception to find a landlord who was not ready to bear his share of the burden, and, by liberal remissions, 


\section{THE MALIGNED LANDOWNERS}

help his tenantry over their difficulties. Had it been otherwise the counties would never have stood, as they have in so many instances, by the landed interest, subjected as it was to an unparalleled storm of abuse, and sent to Parliament the very men whom, they were told, were their worst enemies. Happily, country-side folk have not yet accepted as gospel the doctrine that every rich man is an idler and every idler is a rich man, for Hodge is not such a fool as some political leaders appear to fancy him. I have seen enough of landowners during the best part of fifty years to be able to say this much on their behalf with a clear conscience. 


\section{CHAPTER $\mathrm{X}$}

The Royal Agricultural Society - The Shorthorn Boom - John Thornton-The Bath and West Society-A Kindly Send.off.

T 1870 the Royal Agricultural Society of England held its annual show at Oxford, 1 under the presidency of the then Duke of Devonshire, and the Oxfordshire Agricultural Society suspended its show for that year, in order to devote its energies in support of the national Society; it also made a liberal monetary grant from its funds towards the prize list of the visiting Society. It was at Oxford in 1839 that the Royal Society started on its career of usefulness, under the title of the English Agricultural Society, with Earl Spencer, its founder, as its first president. My father, who actively interested himself in the inauguratory show, gave me many particulars of it which testify to the remarkable progress made by the Society since then. In 1839, a field of six acres was sufficient for all it had to accommodate, which comprised 350 entries of stock and 23 of implements, and two days covered the duration of the gathering. Its members were 1800 in number and the amount offered in prizes was £750. The Society is too well known for a comparative statement showing how it has progressed since then to be necessary, but few 


\section{THE NATIONAL SOCIETY}

organizations can ever have surpassed it in rapidity of growth and development. A great feature in its early years was the annual dinner, long since discontinued. As no existing building in the city was large enough to accommodate all those desiring to be present, it took place in 1839 in the Quadrangle of Queen's College, which was roofed in for the purpose. About 2500 persons sat down, for whose benefit 3874 lbs. of meat were cooked.

I saw a good deal of the 1870 exhibition, as at the request of the then secretary, Henry Michael Jenkins-whose brilliant and versatile career was, owing to the inroads of illness, all too brief-I undertook the supervision of the issue of the show catalogue. This necessitated my being at the show from start to finish, but I was glad to accept the commission, as it gave me an opportunity of seeing something of the inner working of a great show at a time when I was endeavouring to learn all I could of such matters. The 1870 meeting was notable for one or two things, foremost among them being the establishment of that most useful form of competition represented by the offering of a premium for the best-managed farm. The originator of this was the late Mr. James Mason of Eynsham Hall, Oxon., a country gentleman and a vicepresident of the Oxfordshire Agricultural Society, who gave a piece of plate of the value of one hundred guineas for the best-managed farm within a defined radius, the Society supplementing it by a second prize. There were twenty-one competitors, and no little sensation was caused 


\section{FIFTY YEARS OF A SHOWMAN'S LIFE}

by the award of the first prize to a woman. The Society and agriculturists generally were so convinced of the value of the competition that it was accorded a permanent place in the Society's prize sheet. The show was further impressed upon the memory of those who attended it owing to the meteorological conditions during that week, for it was held in the midst of a heat-wave suggestive of the Tropics, and which resulted in several cases of sunstroke. Then the show dwells also in memory in connection with a world-wide catastrophe, for in the midst of it a telegram reached the yard announcing France's declaration of war against Prussia.

Among my other notes of the show, I find some particulars of sales effected in the yard, which may be worth recalling for purposes of comparison. A short-horned yearling heifer, "Knightly 2nd," bred and exhibited by Mr. McIntosh, of Havering Park, Romford, and awarded a first prize, was sold for five hundred guineas, to go to New York. Mr. Bruce's shorthorn bull, "Scotsman," a first-prize winner, bred by the Duke of Buccleuch, fetched two hundred guineas, to go to Canada. Two hundred and fifty guineas was offered for Colonel Townley's bull-calf, "Townley Oxford," a commended exhibit, and Mr. Middleton's two commended Channel Island cows realized one hundred and forty guineas each. There was at that time a greater demand for pure-bred shorthorns than had ever been known before. This was borne out previous to the show by the refusal of Mr. T. C. Booth of two thousand guineas for "Lady Fragrant," and his 


\section{A BOOM IN SHORTHORNS}

acceptance of fifteen hundred guineas for "Lady Grateful," sister of the first-named; whilst Capt. Gunter's pair of cows, "Duchesses 101 and 103," went for two thousand five hundred guineas.

In the 'seventies there was an absolute mania for shorthorn pedigree stock, as is shown by the extraordinary prices paid for some of the fashionably bred types, especially of the Bates and Knightly lines. At Lord Dunmore's sale in 1875, with the late John Thornton in the rostrum, the whole world was astonished when the shorthorn bull, "Duke of Connaught," was knocked down to Lord Fitzhardinge-president of the Bath and West Society in 1893 - for the sum of 4500 guineas, the largest amount for a shorthorn ever realized in England at a public sale. Visitors from near and far made pilgrimages to Berkeley Castle to see what so redoubtable an animal looked like. He was a very harmless, well-behaved, domesticated sort of beast, with none of the savage attributes bestowed by timorous females upon bulls in general, for he would answer to his stable name of "Tommy," and follow his lordship round the yard from his box like a dog when the pole-star was a carrot. I never beheld this notable bull in the flesh, but I have seen his skin in the hall of Berkeley Castle, where it formed a fine mat in front of the large, old-fashioned hearth. About the same time Lord Bective gave $£ 3500$ in America for the shorthorn cow, "6th Duchess of Oneida." Verily there were giants in those days in the way of bidders.

Within the last year or two there has been a recrudescence of this demand for shorthorn 97 


\section{FIF'TY YEARS OF A SHOWMAN'S LIFE}

pedigree stock, as shown by the large prices realized at auction sales.

John Thornton, just referred to, whose friendship I enjoyed, was the agricultural auctioneer of his day, and he was well entitled to the exceptional position awarded to him by common consent. The very embodiment of integrity and straightforwardness, he had a marvellous knowledge of stock, whilst his geniality of presence and of manner was in itself sufficient to inspire that cheerful condition of mind most to be desired in bidders. His power of persuasiveness and ready wit stood him in wonderful stead when he had the hammer in hand, while his imperturbable good humour was equal to any strain put upon it. His method was an object lesson in the art of conducting an agricultural auction sale.

When in 1878 the Bath and West Society held its annual show at Oxford, I little thought that I should ever have to administer its affairs. At that time I was not only secretary of the Oxfordshire Society, but also editor and manager of the Oxford Journal, the agricultural organ of the county, so I saw a good deal of the show in this dual capacity. When the visit was arranged, I must confess, as secretary of the smaller Society, I viewed the advent of the larger one with some misgivings, and, as the Oxfordshire Society had not been taken into the confidence of the Western Society, with a disposition to give the latter the cold shoulder. But, on second thoughts, it occurred to me that it might pay better to try and make terms. After some negotiation, the 


\section{A MA'TTER OF NEGOTIATION}

terms I made-and the then secretary of the Bath and West Society assured me that they were more liberal than had ever before been granted to a provincial Society-were that, in return for suspending our show for the year, and making a contribution to the prize list of the visiting Society, our members should be put on precisely the same footing, with respect to admissions, entry fees, etc., as the members of that Society. This satisfied our members, because they had a five days' instead of only a two days' show-and a much more extensive one, to boot-for their money, whilst, if they exhibited, they had the opportunity of competing at a low rate for a considerably larger amount of prize-money than ordinarily. Beyond this, local classes were provided to meet the special wants of exhibitors in the district. Under these satisfactory conditions we drew our subscriptions as usual for that year, whilst we were relieved from any risk of holding a show. That the course pursued did not prejudice our future was shown by the success of our shows in following years. These are the terms which, I think, a visiting Society should be prepared to offer and a County Society to accept, and if this be done, I believe that the result will be satisfactory to both parties to the transaction.

At any rate, I thought the arrangement so far fair to both sides, that when I had, as secretary of the Bath and West Society, to deal with a similar position, I advised the Council permanently to adopt these terms in the case of provincial Societies, and this was acted upon, and has prevailed ever since. Here came in the advantage 


\section{FIFTY}

of having had to study the question from the opposite side, thus enabling one to judge the position from the other man's standpoint.

Up to this point these reminiscences have been derived from my association, lasting from 1867 to 1882, with the Oxfordshire Agricultural Society. The last-named year saw an enlargement of the area of my work and a change of environment. In the autumn of. 1882 was announced the pending retirement of the secretary of the Bath and West and Southern Counties Society, and I joined the ranks of the many aspirants to one of the most coveted positions in the agricultural hemisphere. Of the 1072 candidates who applied in the first instance, 342 stayed over the whole course. After a very careful consideration of the qualifications of all these, the committee of selection, of which the late Sir John Duckworth was chairman, by a gradual process of elimination, brought the number down to the lowest possible denominator, submitting one name only to the Governing body, with whom the final choice rested. The Society's Council unanimously endorsed the Committee's recommendation, and thus I became the seeretary of one of the oldest and most important of agricultural organizations. Stranger as I was to the West, I owed my success mainly to the generous testimony borne on my behalf by those whom I had previously served, from the LordLieutenant of my native county downwards. I may add-after fifty years' close intimacy with those of whom I speak-that no section of the community are more staunch in their friendships, more faithful in their attachments, or more loyal 


\section{GO TO BATH,}

to those in whom they put their trust, than agriculturists, whether landowners or tenant-farmers.

For some years after I had settled down in Bath, I continued to hold certain of my Oxford appointments, which meant much travelling to and fro. But I could not urge the Bath and West Council to fall in with the request of my old Society that I should run that Society as well as the Western one, as I knew enough of human capacity to feel that that would soon mean two vacant secretaryships, owing to the interment of an official who had bitten off more than he could chew. So, sorrowfully relinquishing a trust, which, though unwillingly undertaken in the first instance, had been fruitful in friendships and much else worth having, I transferred myself and my belongings to the classic city of Bath, in the trustful hope-since most amply realized-that I might find as good friends in the West as those with whom I was parting.

Where, as in the case of a big show, success depends upon completeness of organization, I may say, for the benefit of anyone with aspirations in this direction, that the first axiom that the showman's mind should get a good grip of is "Never leave anything to chance"; a neglect of this may be fatal. I will illustrate this by narrating one of the last incidents connecting me with the Oxfordshire Society. Full of gratitude to those who had stood so well by me, and only too anxious to show this in any way, I willingly responded to the wish of the Society that I would help them to find my successor. It so happened that on the staff of the retiring 


\section{FIFTY Y YARS OF A SHOWMAN'S LIFE}

secretary of the Bath and West Society was a young man, R. H. Rew, by name. It needed but a brief acquaintance with him to convince me of his capacity, so I proposed that he should continue in the office by joining my staff. He confided to me that he should prefer the more responsible post I was about to vacate. I thought this a very natural aspiration, and, being satisfied that my old Society would be well served by him, I encouraged him to proceed and gave his candidature all the backing I could. The selection committee, of which I was a member, having the courage of their convictions, followed the example of the Bath and West Committee, and, out of a goodly number of candidates, returned only one name, that of R. H. Rew, and recommended his election to the general committee of the Society, who were the arbiters of the situation. His strongest opponent among the candidates was a land-agent in the county, in close touch with the agriculturists of the district, with whom he was very popular. He had many friends on the general committee, who determined to run him for all they were worth in opposition to the candidate, who was unknown to many of them, recommended by the selection committee.

Aware of the strength of the supporters of the local candidate, I could see he stood a very good chance of winning. Therefore, previous to the decisive meeting, I strongly urged upon all favourable to Rew to make a point of attending it. Among others to whom I appealed was the late Mr. George Herbert Morrell, M.P., a vice-president of the Bath and West Society as well as of the 


\section{WON BY A NECK}

Oxfordshire Society, who regretted his inability to be present as he had to be on the County Bench that morning. He very kindly promised, however, that if, after the meeting had assembled, I was still of the opinion it would be a close thing, and would send a note to that effect to him at the County Hall, which was within a short distance of the Town Hall, where the Committee met, he would leave the Bench and come up to vote. As I looked round the meeting, it did not take me long to realize the necessity of dispatching a messenger post-haste to the County Hall. Pending the election of a new secretary, I was still responsible for the discharge of the duties, so, with one eye upon the door, I dallied a good deal over preliminaries, including the reading of the minutes, over which I lingered as though loath to part with them. Still, there was no response to my note, and I was nearing the end of my procrastinating resources, and the division was imminent, when, to my intense relief, the cause of my delay suddenly appeared in the doorway, just in time to turn the scale for Rew, who was elected by a single vote.

His after-career furnished the amplest justification for those of us who promoted his candidature. After a most successful association with the Oxfordshire Society, he became secretary of the Central Chamber of Agriculture, migrating thence to the Board of Agriculture, where, as everybody knows, he occupies with much distinction an important position as Sir R. H. Rew, K.C.B. So I have the satisfaction of feeling that I did a good turn for my old Society when I sent that urgent note to the County Hall. 


\section{FIFTY YEARS OF A SHOWMAN'S LIFE}

I should not be doing justice to the kindly feeling of my good Oxfordshire friends were I to leave unrecorded the final incident of my association with them. At the annual dinner of the Oxfordshire Society, following my relinquishment of the secretaryship, I received, at the hands of the late Earl of Jersey, acting on behalf of the members, an illuminated address, accompanied by a most generous monetary presentation. The value to me of such a recognition was greatly enhanced by the medium through which it reached me. While Lord Jersey was distinguished in the world of Imperial politics, winning, as Governor of New South Wales, and in other capacities overseas, golden opinions, as well as in that of Agriculture, he was absolutely idolized by those in whose midst he lived, as the most perfect embodiment of those qualities which dignify humanity and ennoble life. In the days when, as I have narrated, I was struggling amid difficulties to justify the trust reposed in me, I owed more than I can say to his kindly sympathy and encouragement; a help in times of stress and strain, which can only be properly estimated by those who, in the hour of need, have found it. He was very much my agricultural godfather, always ready to go bail for me, and to promise and vow anything on my behalf.

During my showman's career, I have had good reason to be grateful for many sunny memories, and not the least of these is the recollection, which will ever remain with me, of that demonstration of human kindness that gave me so golden a sendoff to the West. 


\section{CHAPTER XI}

My New Sphere of Work-Next Door to a Tragedy - Signs and Omens -A Chamber of Horrors.

7 HERE was a marked difference between the personnel of the governing body to which I had been hitherto attached and that to which I now owed fealty. All the really active workers in the Oxfordshire Society were farmers pure and sinple, whilst in the Bath and West Society, although the tenant farmer element is not unrepresented, the governing influence of the Council-room and the show yard rests mainly with the landed interest. It is safe to say that each of the two associations has the governing body, so far as its constitution is concerned, most suitable to its needs, as is shown-on the principle that the proof of the pudding is in the eating-by the prosperity they both enjoy. The larger Society, with its wide area and diversity of operations, calls for a controlling body accustomed to handle matters in a cosmopolitan and enterprising spirit and with a knowledge of the world in general as well as that of agriculture. In accordance with this, Parliament, Quarter Sessions, and County Councils are all well represented on the Bath and West Council, to its manifest advantage. In close touch with country-side life, whilst in most cases possessing also a knowledge 


\section{FIFTY YEARS OF A SHOWMAN'S LIFE}

and experience derived from contact with other sections of the community, representatives of this type, with the advantage of such training, are enabled to deal with affairs somewhat diverse in character in a broad-minded spirit. The work accomplished by the Society, during its long and progressive career of nearly one hundred and fifty years, is the best testimony of the capacity of its administrative body, whilst the support it has received from the chief stock-breeders of the Kingdom, as well as from the leading agricultural implement firms, is good evidence of the practical character of its system of government.

The Society was very fortunate at its initiation in securing the support of men who were not only devoted to its interests, but had the knowledge and capacity to render their zeal effective. Happily, the old tradition still holds good, as the roll of those who hold office in this year of grace amply testifies. At the Society's Centenary Meeting, in 1877, the late Earl of Cork gave appropriate expression to this source of strength when he said: "One of the great causes of the success of this Society is that it has been always managed by thoroughly practical men, who have had their heart and soul in the work. If it had not been for this, if the Society had been left chiefly in the hands of ornamental members meeting only once a year, it is very doubtful whether we should have seen the hundredth anniversary."

The minutes furnish several examples of a continuity of family interest in the Society. An intimate connection between the past and the 


\section{CONTINUITY OF INTEREST}

present dates back to 1786, when it was announced that Sir Thomas Dyke Acland, Bart., had joined the Society. This was the great-grandfather of the present baronet, and so, for more than a century the honoured name of Acland has been con tinuously found upon the roll of members. In the same year, the eldest son-Viscount Weymouthof the then Marquis of Bath took part in the Society's ploughing competition, and, since that time, both the father and the grandfather of the present Marquis have held office in the Society, whilst he himself has twice occupied the presidential chair. Such instances, in which this interest has been handed on from father to son, have long been a happy feature of the Society's history; I myself have seen, during my tenure of office, three generations of one family successively occupying positions in the Society.

I soon found that my new post was no sinecure, and I should have been disappointed had it been so. My predecessor had been for years a confirmed invalid, and, although, with indomitable courage, he faced and overcame many almost insuperable difficulties arising therefrom, there was bound, under such circumstances, to be a good deal of lee-way in the general management to make up. The Society's Council, in the practical spirit with which they were accustomed to deal with administrative details, took the opportunity of a change of secretaries to disestablish three or four other officials, so as to concentrate everything possible in the secretary's office. This was a wise proceeding, as it made one official responsible for the general management, 


\section{FIFTY YEARS OF A SHOWMAN'S LIFE}

and did away with a certain amount of overlapping of duties not conducive to economy of either time or money. The Council also determined to inaugurate the new régime by dispensing with a contractor for the erection of the show yard buildings and becoming their own contractors with a steward of works to supervise. This arrangement has been in operation ever since, and has resulted in a saving to the Society of some thousands of pounds.

So for the first few years of my tenure of office I had to "scorn delights and live laborious days," in order to bring things up to that level of efficiency which is represented by the phrase "smooth working." For the first three months after I took up residence in Bath, I spent a good deal of time in railway-carriages, in order to fulfil some Oxford responsibilities-including the editing and general management of a newspaper-of which I could not all at once divest myself. Hence I had a somewhat strenuous time before settling comfortably down in the saddle. Happily, my assistant secretary, to whom I have already referred, as having enabled me to surmount the special difficulties, which beset me when I first turned showman, retained her old post after our migration to Bath. Inasmuch as I found my own staff, this was a distinct advantage from more than one point of view. She was not long in fully justifying her claim to the title in a new sphere, and for many years the knowledge and experience she had gained in show work did much to mitigate the stress and strain inevitable when there was much overhauling and re-organization 


\section{WORRY NOT WORK THAT KILLS}

to be carried out. Being my help-meet in the eyes of both Church and State, and the partner of my joys and sorrows, there was not likely to be any lack of confidence between us, and - an in. estimable blessing-she was always on the spot, irrespective of office hours. It was not long before she came to be as fully recognized under the title of "assistant secretary," in the Bath and West, as she had been in the Oxfordshire Society. I retained the services of two members of my predecessor's staff, one of these, to whom I shall pay tribute later on, being with me still.

I have already submitted, as an axiom for the benefit of all having anything to do with shows, the desirability of leaving nothing to chance. I will add to this a further injunction, worthy to be inscribed in letters of gold over the secretarial desk, "Take Time by the forelock and never leave till to-morrow what can be done to-day." It is worry not work that kills, and few things breed the former better than procrastination. There is nothing grandiose in such a prescription, which is quite within the capabilities of the most ordinary of mortals, such as myself, to carry out, but it means much, and whatever success it has been my Showman's lot to achieve is not a little due to my keeping it in the forefront of my mind. This will go far to account for the fact that as soon as one show is over, myself and staff begin actively upon the work of the next, believing that, in the case of an exhibition of the dimensions of the Bath and West one, a year of preparation, allowing for accidents and contingencies, is none too long. 


\section{FIFTY YEARS OF A SHOWMAN'S LIFE}

In pursuance of this policy of avoiding unnecessary bustle, especially towards the finish, I always make a point of settling down in my office in the show yard with my staff a good week before the show opens. The only occasion, since my connection with the Bath and West Society, on which I could not carry out ths condition was at the first of the Society's shows for which I was responsible. I entered upon my duties on the first of January, 1883, and the show was held towards the end of the following May, so it was impossible for me to observe the timerule I had laid down for myself of a twelvemonth's preparation. Beyond this, as I have already explained, Oxford had claims upon my time and attention which had to be met, and so my week in the yard before the show had to be docked of a day. And this brings my narrative to the point at which I have-or my experiences would be incomplete-to record the most exciting, and, while it lasted, tragic incident of my career as a showman. Knowing that my new masters would very naturally judge of my fitness for the office with which I was entrusted by the way in which my arrangements worked out at my first show, I was nervously anxious that there should be no failure in this respect. My future mainly depended upon how, at the onset, I lived up to, or failed to do so, the character my Oxfordshire friends had given me. It will be seen, I think, how momentous, therefore, it was to me to pass unscathed through an ordeal which could either make or mar me.

Every year I have to transfer from my office 


\section{NEXT DOOR TO A TRAGEDY}

in Bath to my office in the show yard not only all the books, correspondence, entry forms, and other documents relating to the show, but all such show machinery as admission tickets, prizecards, judges' and stewards' books, and a host of other paraphernalia, without which you cannot run a show. These necessary adjuncts filled nearly twenty large cases, and, the show being held at Bridgwater, I arranged with the G.W.R. for their conveyance in a horse-box attached to the passenger train in which myself and staff travelled. On arrival at Bristol, an officious official, for some inscrutable reason, and in breach of the understanding between the Company and myself, had the horse-box detached from the train, but promised that it should come on by the next one. All my remonstrances were in vain, for in those early days, when I was a stranger to the West, railways in that part of the kingdom did not know, as well as they do now, the new secretary or his capacity for making himself extremely disagreeable when compacts were not fulfilled.

With a child-like belief in railway officials, not always borne out by maturer experience, I re-embarked in the train, which I had left for expostulatory purposes, and duly arrived at Bridgwater. Having extorted a promise from the officials there that they would dispatch to the show yard the contents of the horse-box immediately on arrival, I wended my way to the yard to make preparations for receiving them. As after two or three hours' wait there were no signs of my cases, back $I$. went to the railway 


\section{FIFTY YEARS OF A SHOWMAN'S LIFE}

station, where I learnt that no one had seen or heard anything of the horse-box. Anxious beyond expression as to its fate, in which my own was involved, I telegraphed to Bristol only to be told that it had been sent on as arranged. In an agony of fear, I instituted inquiries in all directions as to its whereabouts, but without success. At last a porter, with a philosophical indifference which was maddening, calmly remarked that there was a horse-box attached to the Bristol train referred to, but, as no one had unhooked it, it was by this time well on its way towards Land's End.

My feelings on receipt of this information can be better imagined than described. The stewards would be arriving next day, expecting to find the show machinery in working order, whilst all its component parts were being hurried away to regions far remote from the scene of action. I was horror-struck at the thought of having to face the Society and the public with the news that I had lost all the office plant upon which the holding of the show depended, and I had no doubt whatever in my own mind as to the back on which the onus would rest. People don't trouble to go into details in such matters, and it would be simply said that the Society had a pretty fool of a secretary when he couldn't even organize the safe conveyance of his own office plant over a few miles of railway. My whole future depended upon the early discovery of that horse-box, and yet no one could even guess where it was. Telegrams were despatched to every possible quarter, but all in vain. I would have sacrificed a whole year's salary to get hold of it. 


\section{THE MISSING HORSE-BOX}

At last, when in the lowest depths of despair, the very embodiment of hopeless misery, another official, who had not previously been heard of, came leisurely into the limelight and casually remarked, "I suppose that horse-box on the new siding ain't it." Like a shot out of a gun, or a tiger after its prey, I tore round to where the official in question had had a vision of a horse-box. And there, sure enough, within a stone's throw of all the commotion, unsuspectingly wasting its sweetness on the desert air, whilst I was using up all my reserve force in mental anguish, was the missing horse-box. How it came to pass that the official mind was for so long a simple vacuum with regard to the transaction is, as Lord Dundreary would say, "a thing no fella could understand." I can only suppose that those who accomplished the unhooking of the box from the Bristol train departed to their midday repast with the secret locked within their breasts until their return to duty. Or it may be that the extra traffic incidental to the show, being a disturbing factor, upset the mental equilibrium of the station staff to such an extent as to lead them to consign so trifling a thing as a horse-box to the limbo of forgetfulness.

By this time the day was wearing away, so, having seen my bag and baggage loaded up on a trolley I once more made my way to the yard to await its arrival. Further hours passed, and still my precious impedimenta appeared not. It was before the days of telephones, so back I went to the station to find out what had happened to it. I was assured it had departed for 


\section{FIFTY YEARS OF A SHOWMAN'S LIFE}

the yard long since, though by a different route to that I had just traversed. Back I tramped, and, about a hundred yards from the show yard, I descried the trolley, piled up with so much that was dear to me, at anchor outside a publichouse, wherein those in charge of it were solacing themselves with beery libations as though they had the whole year in which to regale themselves previous to getting that with which they were entrusted to its destination. On a neighbouring hillock stood a superior official, apparently on the watch to see how those engaged in the show traffic were performing their duty. To him I forthwith unburdened myself in no measured terms upon the incompetency of railway companies in general, and especially of the particular one from whose neglect I was then suffering, concluding with a request that he would forthwith enter that hostelry and drag forth the miscreants, who, if they remained there imbibing much longer, would be quite incapable of escorting that priceless cargo to where it would be of any use. He listened to me with exemplary patience and in a most sympathetic spirit, finishing up with inquiring what Company the goods in question were consigned to. I told him. "Ah," said he, "I thought so. You should have sent them via Midland. I am a Midland official."

However, he was a good sort, inasmuch as he did my bidding, and succeeded in inducing a beery pair to emerge from their retirement and make leisurely tracks for the show yard. I was close at their heels, never once, you may be sure, taking eyes off that collection of valuables, upon 


\section{"ALL'S WELL THAT ENDS WELL"}

the safe delivery of which my fate depended. By the time my plant reached my office twilight had set in, and so nothing could be done until the next morning. I was up betimes in the hope of recovering as much as I could of that lost day at the cost of a wear and tear, the recollection of which I shall never lose. Happily, the sun shone brightly during the show week, and the turnstiles clicked more merrily than any one had ever anticipated they would, and that always covers a multitude of sins. Hence, as nothing succeeds like success, everybody was in high good humour and said the tide had turned for the old Society. So the showman's reputation was saved, and he had a fair start after all.

But the incident illustrates how thin is the partition that separates success from failure. 1 have forgotten much since then that I wish I could remember, but that day's quest after a horsebox will hold a foremost place in memory so long as reason lasts. I only wonder that, after such an experience, my hair retained its natural colour. From childhood upwards I had always understood that when people went through a period of agonized horror the effect upon their nerves resulted in rendering their head of hair "as white as snow in Salmon." Yet I never turned a hair in the direction of a change of colouring, retaining my pristine vandyke-brown hue till long afterwards; in fact, until Father Time took me gently by the forelock and brought me to what I am by easy stages. I need hardly say that now, when books and newspapers revive this old tradition on circumstantial evidence, I 


\section{FIFTY YEARS OF A SHOWMAN'S LIFE}

do not attach the slightest credence to what they say, being myself a living example to the contrary. Q.E.D.

As a child, I was a firm believer in signs and omens, chiefly because the domestics to whose charge I was consigned had perfect confidence themselves in such things. When the bedroom candle gutterings took a particular shape, I was told, in an awesome whisper, that it represented a winding-sheet, and that its appearance portended the early demise of one of us. I was bidden to be on the look-out for the tick of the death-watch, as I might take that as a certain intimation that my time on this earth was short. If I heard a dog howl at night, it meant that there was a corpse pretty handy, for he had nosed it. The imparters of these legendary portents were country-bred girls, who implicitly believed in these weird warnings, and regarded such knowledge as too valuable to be kept to themselves. According to their experience, witches were as much a part and parcel of the countryside as cattle, sheep and pigs. With bated breath, they told me how these evil-doers got into the farm dairy at night and soured the cream, and how neither bolts nor bars could keep them out of the stable when they desired a nocturnal mount. When, in the morning, Giles went to take out Smiler and Dobbin and their companions for the waggon and the plough, they found them covered with dust and sweat, and "all of a trimble." Then, of course, everybody knew the witches had been there during the night, and had scoured the country on the poor beasts' backs. 


\section{A SUPERSTITION WHICH SUITED ME}

The way to render a witch innocuous was to get blood from her, and this had been most successfully done, as the reciter of these legends knew from direct evidence, by drawing a large needle smartly down the length of her arm, after which you were safe from her machinations.

These particulars, conveyed with becoming seriousness, filled my young brain with all kinds of unhealthy imaginings, and rendered me extremely uncomfortable, especially when darkness set in. Hence, if, in after-years, when I had the responsibilities of parentage, I had found any family-attendants regaling my progeny with such mental pabulum, my discovery of this would have been a sure sign or omen, whichever they liked to call it, that their dismisal was imminent.

My mother had her share of superstitions, but they were of a very harmless character, and related mainly to walking under ladders, upsetting the salt, beginning nothing on a Friday, and, especially, never sitting down thirteen to dinner. This last superstition I cordially approved of. My mother and most of my aunts treated it with a deference, which never permitted of their partaking of this particular meal in company with twelve others all told. So, on more than one occasion, my company had to be requisitioned before the party would consent to fall to. I was most willing to grace the feast on these occasions, thereby enjoying a much more elaborate repast than would otherwise have fallen to my lot. Reverting to signs and omens, and such-like uncanny things, fortunately, by the 


\section{FIFTY YEARS OF A SHOWMAN'S LIFE}

time I had reached years of discretion-or was supposed to have done so-I had so many other things to think about that I had no time for cold shivers at anything less than dread realities; mere presentiments were not good enough.

But I have let my subject run away with me, and have emulated Tristram Shandy himself in discursiveness. All I had in my mind when I started on this tack was to record the nocturnal climax of this nerve-racking day with the railway officials, and at the same time to show how little reason there is to pin your faith to signs and omens. As may be imagined, I was not in a state of boisterous high spirits after that ever-tobe-remembered experience at Bridgwater, when, at nightfall, I betook myself to certain lodgings, adjacent to the show yard, which a friend had secured for me. On entering my bedchamber, death literally stared me in the face, for the sole adornment of its walls consisted of a most choice and varied selection of "in memoriam"" cards, with the deepest of black borders and obituary notices. My landlady's relatives appeared to have had a wonderful capacity for dying, and those whom they left an equally remarkable capacity for accumulating and preserving the most lugubrious records of the fatal event. Here, if so inclined, one could enjoy to the full all the signs and symbols associated with a shuffling off of this mortal coil. Disconsolate maidens wept against sepulchral urns, overshadowed by either weeping willows or cypresses, I don't know which. Cherubims and seraphims hovered over family vaults amid divers emblems of mortality. Ofttimes 


\section{SIGNS AND OMENS DISCREDITED}

since have I had to put up in my temporary sojourns with such horrors as German oleographs and family portraits, but never before or since have I beheld anything quite so morbidly gruesome, regarded from a decorative point of view, as this funereal array. As pointedly crude and blatantly direct warnings to prepare for the worst, they threw ticking death-watches and tallowy winding-sheets completely in the shade.

Yet I was practically unmoved; with a show on one's mind everything else sinks into insignificance. A fall in the barometer, presaging foul weather for the show, would weigh far more heavily on my spirits than all prognostications of impending dissolution put together. Now to showmen with a disposition to attach undue importance to portents and to render themselves uncomfortable in consequence, I offer the foregoing particulars with a view to easing some of their fears. Nothing could have foreboded worse for my future career in the Bath and West Society than that prelude to my first show. Yet the show itself was successful beyond anticipation, and after-happenings have only given me cause for thankfulness. In my childhood's days, if one had been suddenly brought face to face with such a collection of emblems of mortality as met my gaze on the night in question, it would have been regarded as a distinct warning that this world would shortly be relieved of one's presence. That premonition-if it be so regarded-came to me in the year 1883; yet here I am in 1918 still alive and in harness. So much for signs and omens and superstitions generally. 


\section{CHAPTER XII}

A Progressive Society-Dairy Education-The Old Board of Agriculture-Travelling Missioners-The Mischievous Microbe.

VTHEN I first entered upon my duties with the Bath and West Society its operations were limited to the holding of an Annual Show and the publication of an Annual Journal. The Society's financial resources, owing to previous losses on the shows, had become somewhat impoverished, and, just previous to my taking office, the Council appointed what was termed "an economical committee" for the purpose of seeing in what directions the expenses could be reduced. This resulted in several drastic curtailments. But shortly after this Fortune began to smile upon the Society, and the luck changed, beginning with the Bridgwater meeting to which I have just referred.

As soon as it was realized that an era of prosperity had set in, the Council enlarged its grants to the various show committees, thus enabling them to extend the scope of the Annual Exhibition in several directions, and especially by adding to the prize-sheet some breeds of stock not previously recognized. Even before this the show was more cosmopolitan in character than any other gathering of its kind at that time, for, in 


\section{THE SOCIETY'S SCOPE ENLARGED}

addition to encouraging the minor as well as the major features of the agricultural industry, the Society added to the ordinary attractions of such gatherings a flower-show, a poultry-show, a pictureshow, and an art-manufactures exhibition. In later times other features have been added" in the shape of exhibitions illustrative of arts and crafts, home industries, nature study and forestry. The forestry exhibition especially has done much to promote a better knowledge of woodcraft, and attached to it has been a department for giving practical demonstrations in pruning and grafting, which have been most helpful to fruit growers and others. When we are in a mining district classes for timbering and wire-rope splicing are added. The finances having been strengthened by the profits accruing from the annual meetings, the Society's Council, besides extending the area and the usefulness of the shows, appointed a special committee to take into consideration what further assistance could be rendered to the national industry. This bore fruit in a series of recommendations, adopted by the Council, inaugurating a new departure and opening up fresh fields of operations. Briefly summarized, the proposed extension embodied the establishment of a system of practical experiments with respect to the effect of artificial manures on both corn and grass; the examination and testing of any new processes dealing with agricultural produce; the setting on foot of research work in dairying and other branches of agricultural industry; the provision of special facilities for imparting knowledge in such subjects; and the collection and publication 


\section{FIFTY YEARS OF A SHOWMAN'S LIFE}

of information upon various branches of agriculture, especially that resulting from the Society's investigations.

No time was lost in giving effect to this varied programme, and ample proof of the practical utility of the work thus carried on over a long series of years is to be found in the very full account of it in the many printed reports issued from time to time by the Society. The Government, as represented first by the Privy Council and afterwards by the Board of Agriculture, fully recognized, in reports to Parliament and by grants in aid, the value of the work thus undertaken.

Some especially important outcomes of the movement, in addition to the land and manure experiments, were the establishment as an important feature of the annual show of a working dairy, in which lectures, demonstrations, testings of new processes and implements, and competitions were held; the organization, by means of schools, of systematic instruction in dairying and farriery ; and the provision of stations for experimental and research work in connection with cheese-making, cider-making, etc.

When, by the Local Taxation Act of 1890, County Councils had funds placed at their disposal for the promotion of technical education, several of them appealed to the Society to conduct dairy schools on their behalf and made monetary grants for the purpose. The Society willingly responded to such appeals either by equipping and conducting schools or by rendering such help as enabled others to do so. The extent of this development of the Society's work 


\section{DAIRY EDUCATION}

may be judged by the fact that it originated and carried on 169 butter schools attended by 3084 students, in sixteen different counties. These schools were migratory, holding a certain number of sessions in a district and then moving on to another centre, and the Government Inspectors who visited them testified in the highest terms as to their efficiency. The cheese schools remained in one place for the whole of the cheesemaking season, and the following year moved on to another district, the educational course for each student being necessarily much longer than for butter-making. Fifteen of these schools were held, and were attended by 706 students. In a report presented to Parliament by the Board of Agriculture, in which detailed particulars were given of the work of the Society, the latter is credited with having "been virtually the pioneer in the establishment of dairy classes." With reference to the cheese school, it says: "The pupils were mostly of the farming class, and the results of instruction, so far as can be ascertained, are better produce and better prices. Some large cheese buyers in the neighbourhood have spoken highly of the value of those cheese schools in the way that they are improving the make of cheese in the district." The report also alluded to "the interesting results and observations" recorded in the experimental section of the cheese school, and reproduced a considerable portion of the report of the Society's expert, which had appeared in the Society's Journal. The Board further showed its appreciation of the schools by grants in aid. 


\section{FIFTY YEARS OF A SHOWMAN'S LIFE}

There is a document in the Society's possession which forms an interesting link between the present and the past. It is a communication addressed in 1795 by the President (Sir John Sinclair) of the first Government Board of Agriculture to the Society's secretary, testifying to the good work the Society was then carrying on, and expressing a desire still to further utilize it, whilst one of the earliest acts of the presentday Board of Agriculture was, as already stated, an official recognition of the Society's efforts.

The old Board of Agriculture was established in 1793, its initiation being due to Sir John Sinclair, who became its first "President." He had considerable difficulty in inducing the Government to entertain his proposals, and this led to a singular difference between Arthur Young and himself. The former betted the 19 volumes of his Annals of Agriculture against Sir John's 21 volumes of his Statistical Account of Scotland that Sir John would not succeed in his efforts. The Board, however, was established, and Young was appointed its first secretary, but it lacked the necessary vitality to give it length of days, for it ultimately flickered out, in 1820, and comparatively few persons are now aware that it ever existed. The fact that the old Bath and West Society has outlived by many years an institution which had the active interest of the King, the support of such statesmen as Pitt and Fox, and the pecuniary help of the Governments, affords some testimony of the vitalty of voluntary effort.

Since the establishment of the Butter and 


\section{SYSTEM $v$. RULE OF THUMB}

Cheese Schools in 1888 and up to the end of 1905 , the Society, in conjunction with County Councils and other public bodies for whom it had acted, expended no less a sum than $£ 31,940$ in the promotion of techincal instruction in dairying through the medium of these schools. Even this amount by no means represents the total expenditure, for it does not include many local expenses, in connection with the travelling butter schools, defrayed by local bodies co-operating with the Society. The Society carried on these schools until County Councils were able, by the light of the Society's experiences, to undertake the conduct of them themselves.

It is impossible to over-estimate the gain to the agricultural community by this method of disseminating a knowledge of this important branch of the industry. It substituted for mere rule of thumb carefully thought-out methods, the value of which had been tested scientifically as well as practically on the latest principles. In dealing with the various problems arising out of the new work, the Society had the assistance of its permanent staff of consulting officials, leading experts in their several departments, these including the late and the present Dr. J. A. Voelcker, M.A., F.I.C., F.C.S., the Society's consulting chemist; Professor W. Carruthers, F.R.S., its consulting botanist; the late Professor Sir George Brown, K.C.B., its veterinary adviser; and Mr. F. J. Lloyd, F.I.C., F.C.S., its dairy and cider expert; whilst its Committee of direction, being composed of men whose intimate knowledge and experience of the conditions under which agriculture was 


\section{FIFTY YEARS OF A SHOWMAN'S LIFE}

carried on, supplied just the element required for the linking up of practice with science.

These new departures meant, of course, a considerable addition to my work and responsibilities and a good deal of travelling by road and rail, but the immeasurable advantage such a policy conferred upon agriculture and upon the country at large, by encouraging increase of production and improvement of methods, was sufficient to stir one's enthusiasm in regard to it. The distances separating the various schools and experiment stations necessitated frequent travelling, for each locality had to be visited for the arrangement of preliminaries and during the progress of operations. So I traversed some thousands of miles in railway carriages and road vehicles, in company with the late Mr. George Gibbons, my brother-missioner, of whom I shall speak later on, and stood with him on innumerable platforms pointing out with all the oratorical force of which we were capable the advantages country-folk could derive by availing themselves of the educational facilities the Society offered. It was rather uphill work at first until those whom we desired to benefit realized the disinterestedness of our aims; then lukewarmness was succeeded by whole-hearted appreciation, and the cause made rapid headway. In connection with the dairy schools, the first difficulty we encountered was due to the reluctance of the farmers' wives to allow their daughters to churn and carry out other operations necessary in the making of butter in the glare of publicity. They thought it was infra dig. for "our Susie" to be seen. 


\section{SETTING THE FASHION}

engaged in manual work. Of course in these latter days, when women in all stations of life are cheerfully rendering invaluable assistance in many departments of farm life, it is difficult to understand such objections as we met with. But, even in those slow-moving times, the diffculty was met, and in this way. We went to the squire and the parson of the parish, when they had a wife and daughters, and begged them to set the fashion by inducing their women folk to join the classes and take part in the competitions. Those appealed to willingly responded, and then all objections dissolved into thin air, for Mrs. Brown, of the Manor Farm, could not possibly object to her daughters doing what those from the Court or the Parsonage saw no harm in doing themselves.

The rector or vicar oft-times found a text for an address to the students in the assertion that all honest work, whether of head or hand, was ennobling, and when he pointed the moral by sending his own daughters to the school no one could question his sincerity; it was Mr. Squeers' system without its drawbacks. On several occasions we had pupils with handles to their names, whilst a Girton girl has been among the prize-winners. It has sometimes happened that a student had doubts as to whether it was not a little infra dig. to fetch, carry and clean in public, but the example of the squire's daughters, with their sleeves tucked up, shirking none of the hard work, has done something to overcome any such scruples. In other respects, too, this intermingling has been an advantage, affording 


\section{FIFTY YEARS OF A SHOWMAN'S LIFE}

little opportunities for kindly courtesies and for an interchange of experiences. There is a levelling tendency in hard work when the workers stand side by side on a footing of equality and are actuated by the same desire to master an art. A sympathy may thus be created between sections of the community which do not ordinarily come into such contact, ending probably in a better understanding of the nature of each. A mistress may leave the work of her dairy to others to carry out, but she can exercise a much better control over it, and be a much more efficient and, at the same time, considerate critic when she has learnt the "how" and the "why" in a practical school, where she has been brought face to face with some of the incidental difficulties. So, although the primary object of the school was to impart instruction to those who were actually engaged, or were about to engage, in the business of dairying - and none of these were elbowed out to make room for any others - the society welcomed all comers actuated by a thirst for knowledge, and has seen no reason to regret a cosmopolitan policy in this respect The greater interest those outside the actual sphere of farming can be induced to take in agricultural pursuits, and the fuller knowledge they have of them, the more will they appreciate the farmer's trials, and the less likely are they to misunderstand his motives.

Until the establishment of the experimental and research section of the Society's Cheese School little had been done in this country towards investigating the manufacture of cheese from a scientific point of view. While good 
cheese was made, the quantity of bad cheese was out of all proportion to what it should be. Taints were prevalent without in most cases makers having any knowledge as to how they were produced or how they could be prevented. Often the cause was put down to the nature of the land on which the cows fed, and farms were frequently condemned as unfit for dairying on this account. All the Society's investigations, however, go to show that the land had no more, as Koko would put it, "to do with the case" than "the flowers that bloom in the spring" had to do with his matrimonial future. The Society when it annually set up its Cheese School looked out not for a farm which had the reputation of being a good one for cheese-making, but for one of evil character in this respect, and in such cases the price made by the Society's cheese was quite sufficient to show that the land had not been the offending party in the past. For three consecutive years the school was located in a district where it was said that the land prevented the making of good cheese. In each case analysis of the soil failed to show the presence of any chemical constituent which would be injurious to the milk or the cheese made therefrom, whilst from a careful examination of the pastures it was equally clear that no vegetable growth that could possibly injure the milk or the cheese was included in them. The evidence accumulated by the Society has done something to controvert this ancient tradition, particularly prevalent in Somerset. Insuffcient skill in carrying out the necessary processes 


\section{FIFTY YEARS OF A SHOWMAN'S LIFE}

of cheese-making will, of course, apart from anything else, result in bad cheese, but it was proved that of the inferior cheeses made by an expert maker 75 per cent. of the inferiority was due to taints. These are almost entirely owing to the presence in the milk of microorganisms or bacteria, resulting either from lack of cleanliness, in milking or subsequent operations, contaminated water, or impure milk. One of the Society's objects was to discover the cause and source of taints and to learn how best to prevent or modify their harmful influence. This has resulted in putting the cheese-maker in possession of many important facts, which without the aid of systematic investigation pursued in a scientific spirit would have remained undisclosed to him.

These investigations were carried on by the Society over eight consecutive years, full particulars of the work, with the results obtained, being annually recorded in the Society's Journal. The Government regarded these investigations as of so much importance that, when they were concluded, they published, with the sanction of Parliament and the Society's concurrence, a full report of them for wide distribution at the cost of the State. 


\section{CHAPTER XIII}

The Divining Rod-John Mullins-Divining Methods-Conclusions arrived at-Letter from a "Dowser."

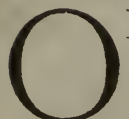

NE day in 1888, when on the business of the Bath and West Society, I was in the Board Room of the G.W.R. at Bristol, where I found the late Mr. W. J. Brown, of Middlehill House, Box, a member of the Society's Council and of other public bodies, and a man whose integrity and capacity were beyond question. Soon after my arrival some one called to see Mr. Brown, and, after they had transacted their business, the latter asked me if I had ever seen a water-diviner, as he could show me one. I replied that I had only heard of such persons, and didn't much believe in their supposed powers. He then introduced me to the late John Mullins, of Colerne, who, he said, had been most successful in finding water on his (Mr. Brown's) property. After I had had some conversation with Mullins, my friend asked him to leave the room for a few moments. When he had done so Mr. Brown informed me that, although Mullins would not bind himself to find anything but water, he had had proof of his capacity to discover hidden metals, and he would test it in my presence. He then took three sovereigns from his purse and placed 


\section{FIFTY YEARS OF A SHOWMAN'S LIFE}

them in a line, and several feet apart, underneath the Turkey carpet. I may say that the door of the room was closed, and that no one could observe our proceedings through the keyhole, as it did not command the end of the room we were in. We then called Mullins in, and asked him to use his rod along the left-hand side of the room. He took a forked twig from his pocket and proceeded up the room with it, holding it in front of him. It showed no agitation at first, but soon did so, and we marked the spot with a piece of paper. Twice afterwards this occurred, and Mullins said that probably he had come across some water conveyed under the flooring, for the supply of a cistern. We then turned up the carpet and found the sovereigns on the spots indicated by the rod.

It was this circumstance which first aroused my interest in the subject, and I thought it sufficiently remarkable to be recorded here, but, at the same time, my observations have not led me to believe that diviners are so invariably affected by the presence of metals as of water. I have read of instances where diviners, other than Mullins, have failed to discover metal under similar conditions to those just narrated. Mullins, however, told me that, although he could detect the presence of gold, he did not feel equally sure about other metals, and, in fact, that he did not bind himself to find anything but water.

As the subject often came under discussion and invariably led to considerable difference of opinion - the practical man usually being a believer and the scientist invariably a non-believer in the 


\section{WATER DIVINING}

power-I thought the matter was worth investigating, and so I sought an interview with Mullins to start with. He was a stonemason, but had so much of a reputation as a water-diviner that a good deal of his time was spent in searching for water in various parts of the kingdom. He undertook to sink wells in localities where he had previously stated water would be found, and in cases which came under my notice had acted upon the principle of " no cure, no pay," by contracting to make no charge for sinking the well if a plentiful supply of water were not forthcoming. I interviewed Mullins on more than one occasion, and have been present when he has been searching for water. $\mathrm{He}$ was open and straightforward ir: manner, and without any of the outward characteristics of the professional charlatan. He put on no air of mystery or pretentiousness, but appeared ready and willing to tell all he knew, and to submit to any practical test. I catechized him on various points, and obtained the following answers to my questions. He had no reason to believe, he said, that he inherited the divining gift. $\mathrm{He}$ discovered it in himself during his boyhood, when, having witnessed the operations of a "dowser," he picked up the twig and ascertained he could use it. $\mathrm{He}$ found a hazel twig gave the best results and a hawthorn one next, but had no idea why; box, elder, and plane would not do at all. He felt a sensation in his arms similar to that produced by a very slight electric shock when the rod was agitated by the presence of water or metal, and the degree of force in the sensation enabled him to say whether the spring was a 


\section{FIFTY YEARS OF A SHOWMAN'S LIFE}

strong or a weak one, and, usually, to predicate the depth within a few feet. A twig of some sort was necessary for the discovery of water underground, but when standing over a strong stream above-ground he felt a slight tingling sensation, although he might not have the rod. I particularly inquired of him whether the power was influenced in any way by the state of his health. He said that when he had a bad cold or was otherwise indisposed, he felt an exhaustion after using the rod, such as he would not experience at other times. As he himself put it, "It seemed to take more out of me then." A too-prolonged use of the rod at any time was apt to produce sleeplessness. He would undertake to find running, but not stagnant, water. He did not confine himself to one particular rod, but usually went to the nearest hedge and cut one when he wanted to use it. His experience led him to believe that the power was more frequently to be met with in women than men. This view has been corroborated by my own investigations in other directions. On one occasion, myself and about a dozen other persons, who were observing Mullins when he was dowsing, all tried the rod at two or three spots where, in Mullins' hands, it indicated the presence of water, and the only person with whom the rod moved was a lady.

I may say that I do not attach any special importance to the mere movement of the rod in the hands of a diviner, as very similar motions can be produced by voluntary muscular contractions. I had evidence of this on the part of a friend, in whose hands the twig moved readily 


\section{THE DIVINING ROD}

enough, and in a way that deceived all who were present at the time, except Mullins himself, who pointed out a slight difference in the movement of the twig, by which he knew it was caused by the will merely of the holder. This my friend at once admitted, and showed us how he did it.

In speaking of the power of the divining rod it must be understood that this is inherent, not in the rod itself, but in the person using it, the rod being merely a means of communication between the person affected and the object which calls the latent faculty to life. The misapprehensions as to this, which have occasionally come under my notice, furnish a reason for stating what to many would appear self-evident. A water diviner is commonly known in the West as a "dowser," and his instrument as a "dowsing rod" or "twig." It is usually a forked branch of hazel, of from two to three feet in length, and shaped like the letter "V." But other mediums are sometimes used; among them being a steel watch-spring, forked rods of iron or brass wire, etc. The dowser's method of procedure to find water, as witnessed by myself, is as follows:- $-\mathrm{He}$ grasps a limb of the twig firmly in each hand, the point where the limbs meet being turned in a slanting direction towards the earth. He carries the twig in front of him and proceeds slowly, necessarily stooping somewhat to bring it as near as possible to the ground. When he comes across running water the spot is supposed to be marked, without any voluntary action on the part of the diviner, by the twig jerking up and down 


\section{FIFTY YEARS OF A SHOWMAN'S LIFE}

and, in some cases, twisting round in the operator's hand.

I collected evidence from many different sources, from landowners of position, keen of intellect and accustomed to sift evidence, from hard-headed practical farmers, with a natural distrust of what they could not fathom, and from Parliamentarians of repute. The evidence in favour of the existence of the power in question was overwhelming. Some of the strongest testimony I received was from the late Earl of Jersey, the Lord Lieutenant of Oxfordshire, afterwards Governor-General of New South Wales, a nobleman of no ordinary business capacity as all who knew him could testify; from the late Earl of Winchelsea; and from many others equally reliable. I was surprised to find how widespread was the belief in divining among agents of large properties, who had tried the diviners by the severest of tests.

I regret that limitations of space do not permit of my giving examples of the evidence which converted me from a doubter into a believer, as it is so convincing. I certainly approached the investigation with but the one desire of ascertaining the truth. Of course, I do not go so far as to assert that there are no failures or no pretenders in this as in other mundane matters.

The one illustration of the power I shall quote is so remarkable in several respects that I feel justified in finding room for it here. It was furnished by Mr. Vaughan Jenkins, of Cheltenham, who, until he had this experience of the power, doubted its existence. He required water on an estate whereon he was about to erect a 


\section{THE BOY “DOWSER"}

residence. The architect fixed upon the most convenient spot for the well, but after the well sinkers had reached a depth of 51 feet they decided, from the nature of the strata, etc., that it would be perfectly useless to proceed further, and the authorities who were consulted came to the conclusion that, owing to the peculiar dip of the land and for various other reasons, there was not the least chance of water being obtained anywhere on this plot of land. One of the workmen, however, persuaded Mr. Jenkins to allow the divining rod to be tried, as he had a son, a boy of eleven years old, who could use it. The rod on being passed over a portion of the land exhibited signs of motion, then began to revolve, and ultimately twisted about to such an extent that the boy was obliged to let it go. The father's positive assurance that there was now a certainty of success induced Mr. Jenkins to sink a well, and, at a depth of 48 feet, they struck on a strong spring of water. In a few hours the well contained 10 feet of water, which occasionally rises now to 15 feet. Mr. Jenkins says : "I was then, and I am now, fully convinced of the total absence of deceit or collusion, and of the full integrity of the whole transaction, no fee or reward being asked for or expected." Here, according to scientific experts, water ought not to have been discovered, but a mere child, unlikely to be guided by any clues supplied by science, proves the contrary.

The value of the evidence in favour of the existence of the power lies chiefly in the following points :

Firstly.-That such evidence is supplied by 


\section{FIFTY YEARS OF A SHOWMAN'S LIFE}

individuals of education and position, whose general intelligence and shrewdness are not likely to be called in question.

Secondly. - That none of it is anonymous in character, but is capable of being verified by a reference to the individual who gives it.

Thirdly.-That it has not been gathered from a band of enthusiasts in communication with each other, and bent upon pushing some theory or hobby to the front, but has been collected from independent and isolated witnesses, who could have no object to serve by misrepresentation.

Fourthly.-That the bulk of it is derived, not from the professional diviner, who has an interest in a belief in it, but from those who lay no claim to the possession of the power they concede to others.

Fifthly. - That much of it is of a corroborative character, as illustrated, especially, by those instances where an amateur has followed the professional diviner, and, without any knowledge of what the latter has indicated, has been correspondingly affected.

This evidence, so far as a plain statement of facts is concerned, can only be impugned on the ground either that the witnesses were accessories to a fraud, or victims of it; and the knowledge one has of them, whether as regards their probity or their acuteness, does not lend itself to either supposition.

But there are some who, while admitting that diviners frequently fulfil what they undertake, deny the existence of any special power confined to certain individuals. They have several ways 


\section{SUMMARY OF SCIENTISTS' THEORIES}

of accounting for a diviner's success, and the following is a summary of them. They contend:

1. - That he makes a guess at the position of what he has to discover, and the fact that he is usually right is a mere coincidence. The adoption of this theory would lead to the conclusion that luck favoured the diviners to a much greater extent than the rest of mankind, and stood by them even when they were blindfolded, which latter has been one of the applied tests.

2. - That a knowledge, on the part of the diviners, of the locality, and of its geology sufficiently accounts for their discoveries. Western diviners, however, are frequently sent for, on very short notice, to distant parts of the kingdom where they have never been before, and with successful results. But, even admitting their possession of a knowledge of locality and geology combined, this would not help them much when they were pasing over artificial water courses and drains.

3. - That the so-called power is merely due to an involuntary muscular action resulting from a fixedness of idea. But there must be something behind the idea which determines its adoption, and the correctness of the results indicates the working of a guiding principle.

Lastly, there is the irrefutable sledge-hammer argument-that there can be no such power as is claimed, because there is no accounting for it within the lines which science, as represented by man (an essential point), has laid down. This is almost equivalent to saying that man has adopted certain principles to which Nature is 


\section{FIFTY YEARS OF A SHOWMAN'S LIFE}

expected to adhere, and that any departure from them is to be rather deprecated than otherwise. A friend once said to me, "As a man, I believe in divining ; as a scientist, I can't."

Many theories have been set up to account for the phenomenon by those who have a belief in it. Some attribute it to electricity, others to magnetism, whilst some cherish the idea that it is an altogether new force which, if its origin and conditions could be traced out, would prove of vast utility and importance to mankind. The faculty possessed by some animals of scenting water a considerable distance off may be worth remembering when we begin to theorize.

Premising, of course, that no claim to supernatural power is, or can be, set up by those who possess the divining gift, to what preliminary conclusions does the evidence seem to point:

1.-That some persons are distinctly influenced by the presence of water or metal.

2.-That this is not due to any law universally applicable to all persons alike, but to some law operation of which is dependent upon certain exceptional conditions in the individual. -

3.-That it is the physical rather than the mental organization that is affected.

Some years ago I laid the evidence I had collected upon the subject before a meeting of the Bath Field Club, when some additional information of a remarkable and significant character was furnished by several members from their own experience. The general conclusion arrived at was that water divining was no myth, but a real power possessed by certain individuals. 


\section{SOME CORROBORATIVE EVIDENCE}

Investigation, methodically pursued, may in time bring us nearer to a solution of the questions -how is that influence generated and what are the exceptional conditions in the individual affected by it? And possibly the germ of a great principle may be found in the answers. This course seems, at any rate, preferable to that of regarding any phenomenon as outside the pale of scientific inquiry if it does not fit in with a preconceived plan of accounting for it. "There are more things in heaven and earth, Horatio, than are dreamt of in your philosophy" is as perfect a crystallization of the truth now as when it was first uttered nearly three centuries ago, and it will probably remain so for many a long year to come.

After I had written the foregoing chapter, I had some interesting corroborative testimony from Mr. A. F. Somerville, of Dinder House, Wells, an active member of the B. \& W. Society's Council, and the Chairman, among other public bodies, of the Somerset County Appeal Tribunal. His shrewd penetration and capacity for sifting evidence add weight to any opinion he may express. He wrote as follows:

"Dear Mr. Plowman,

"Your last chapter of 'Fifty Years of a Showman's Life' was particularly interesting to me, as I am a 'dowser' I have had twigs as thick as my little finger twist off and break after scoring my hand till it was red.

"The muscles of the arm become contracted when the bodily magnetism is affected by the 141 


\section{FIFTY YEARS OF A SHOWMAN'S LIFE}

presence of water, and a strong spring will make my arms ache badly.

"It is quite true that only ' running water" affects me, and on one occasion I had a curious example of this. It was on a Saturday evening, and I quite accidentally found the presence of water close to a house where my sister was living. The following day I told her about this spring and tried the spot, when no effect was observable. On inquiry she told me that there was a pipe underneath connected with a ram which was always put out of action on Sundays.

"I suppose the power must have something to do with the composition of the blood and nerve cells, but I have never yet come across a scientific explanation for this power, which is certainly possessed by many people.

"I do not pretend to be an expert, but in calculating the depth at which water will be found, I assume it to be influenced by the distance from the central point of activity to the end of the radius at which it commences: the further the distance the greater the depth.

"Some 'dowsers' merely use their hands and require no twig or other intermediary." 


\section{CHAPTER XIV}

A Devon Squire-A Somerset Squire-A Kentish Squire.

MONG the leading promoters of the Bath
and West Society was the late Sir Thomas
Acland, for many years one of the most distinguished personalities of the West. The debt which both Agriculture and Education owe to "The Squire of Killerton," is too well known to need recording here, so I will confine myself to depicting those special characteristics which were brought home to me after a long and somewhat intimate personal acquaintance. His very appearance always commanded attention. A certain rugged picturesqueness of face and feature, with a light in the eye that, on occasion, was full of humour, was set off by a strikingly fine physique. Clad in a rough homespun suit, with a satchel of agricultural literature for distribution, slung low down at his side, he would -with some brief spells of rest in the secretary's office-stride about the Bath and West show yard all day with an uprightness of body and a power and elasticity of gait which many a man twenty years younger-for he could thus be seen when he was close upon eighty - might envy.

The versatility of his knowledge was very remarkable. Shortly after my appointment to the 


\section{FIFTY YEARS OF A SHOWMAN'S LIFE}

secretaryship of the Bath and West Society, he kindly invited me to visit him at Killerton. When I accepted, I knew him by reputation only as a great educationalist, and-in connection with the West-as a large landowner, and a staunch supporter of the Society. Concluding that, under the circumstances, Agriculture would be the staple subject of our discourse, I took the precaution, as I travelled down, to read up his views, as expressed in the Society's Journal, in the hope, if conversation flagged, of having something to fall back upon. But I need have had no fears that there would be any hiatus for lack of topics - the difficulty, rather, was the plethora and diversity of them. Nor was it always easy to keep pace with my host's transitions of thought, which ofttimes, with startling suddenness, diverted the course of the conversational current into unexpected channels.

His talk was apt to be a little overwhelming, owing to his complete absorption in any subject uppermost in his mind, and to the velocity with which he poured forth his thoughts; this sometimes lessened the effectiveness of what he had to impart. He could not always pull himself up, even when he felt it was time to do so; and, as he was of too kindly a nature intentionally to overtax anyone's attention, he was full of regrets when he realized the possibility of this.

During that visit, I soon found that, after all, agriculture was but one item in an apparently inexhaustible programme, and, as Sir Thomas could do nothing by halves, his enthusiasm was kindled by whatever had possession of him at 


\section{SIR THOMAS ACLAND}

the moment. In this respect, he bore a wonderful resemblance to Gladstone, with whom he was a contemporary at Oxford, being awarded "a double-first" at the same time that the future Premier gained a similar distinction. If Art were the topic, one could well suppose that it was his predominant passion; but a change of conversation induced the belief that Agriculture monopolized his energies. Ere long, however, one was led to think that Chemistry had first claim upon him, to which conclusion an element of doubt was imparted when the philosophical bent of his mind was disclosed. In this latter direction lay his final literary effort, "Knowledge, Duty and Faith," a title which may be said to embody the watchwords of his own life. Wide, indeed, was the range of his acquirements and of his sympathies.

Sir Thomas took particular interest in dairying, and until the physical disabilities of old age began to assert themselves he was a familiar figure in our show yard dairy, where, at a moment's notice, he would deliver an address upon some branch or other of the subject. No speaker was listened to with more attention, or could command a better audience, for the unconventionality of his style and his resourcefulness of illustration were in themselves attractions. He spoke in a language "understanded of the people"-particularly agriculturists - and he knew how to drive a truth home with a stroke of humour. Countryfolk, when they are out for a holiday, do not usually evince much anxiety to hear others talk, but they would come into my office at the show 


\section{FIFTY YEARS OF A SHOWMAN'S LIFE}

to inquire when Sir Thomas would "lecture"though he, himself, would indignantly repudiate the idea of delivering himself of anything so pretentious, or so cut-and-dried, as was thereby implied. Nor would he enter into any undertaking beforehand to deliver an address upon a specified subject at a specified hour; he disliked what he considered the "ostentatiousness" of this. But some one who knew how to serve the cause would, at a favourable juncture, beg Sir Thomas to say "just a few words" to the buttermaking competitors and others. And then, after a preliminary declaration that he was not going to occupy their time for more than a few moments, he would hold their attention for half an hour at least, and everybody was sorry when he had finished.

He was fearless in the expression of his opinions, whether they were popular or unpopular, and sometimes they bore hardly upon cherished convictions; but his transparent sincerity, if it could not convince, at least, could never be doubted. He was apt to chafe under what he considered the unnecessary restraints and delays of diplomatic methods, and occasionally he hindered somewhat the attainment of an end by too readily taking one of those short cuts which are ultimately found to be the longest way round. His natural impulsiveness led him to prefer a sudden coup de main to a deliberate siege, and when once he had convinced himself-which sometimes happened with lightning rapidity - of the desirability of a certain course, he could not easily realize that there could be any possible obstacle to following it. 


\section{SIR RICHARD PAGET}

When he felt strongly, so he spoke, for speech then was not to be denied. I have known him at a meeting suddenly vacate the chair because he wished, as he put it, "to say something very unparliamentary.'

As, in addition to being one of the Society's trustees, he was chairman of the committee responsible for the Journal, of which, in after years, I became editor, I was in continuous communication with him for a number of years, and this has enabled me to write of him with a degree of confidence that no lesser intimacy could justify. $\mathrm{He}$ was the personification of that disinterested earnestness which, in times of stress and strain, has done so much to sustain Agriculture, and it may truly be said of him that he used the gifts with which he was endowed, and the opportunities resulting therefrom, in a way commanding the admiration even of those who were not always in agreement with him or with the object he had in view.

The beau ideal of a country gentleman of the Joseph Henley type, but modernized and brought up to a later date, was the late Sir Richard Paget, so long one of the representatives of Somerset in Parliament, the chairman of its Quarter Sessions and of its County Council, and the first of authorities upon all matters pertaining to the official side of country life. In a secretarial capacity I have had to do with many men engaged in public work, but I have rarely been associated with any one who was his equal in mastery of technicalities, in grasp of detail, and in getting at the bottom of a question, however complex. Trained in 


\section{FIF'TY YEARS OF A SHOWMAN'S LIFE}

the camp, he learnt, early in life, the value of order, method and discipline, and he brought these qualities to bear in all that he undertook. Polished in speech, and full of courtly grace, he moved, with equal ease and dignity, in whatever company he found himself. His attention to detail was reflected in his dress, for he was always one of the most perfectly costumed and groomed of men. Even the flower, never absent from his button-hole, struck just that note of colour which gave the finishing touch to the whole, whilst neither wind nor weather could ever destroy the impression that he had just stepped out of the proverbial band-box. He looked every inch what Sir W. Gilbert called "the true-born aristocrat," with just that touch of distinction which arrests the attention of the passer-by, and sets him wondering to whom it belongs, certain that it is to some one out of the ordinary ruck.

His services to his county were equalled by those he gave to Agriculture, which is saying a great deal. As he was a vice-president and trustee of the Bath and West Society, as well as chairman of its Education and Experiments Committees, I saw much of him. He was frequently called upon to preside over Council and committee meetings, and, though he could be autocratic on occasion, his intimate acquaintance with the rules of debate, and the tact and courtesy with which he conducted the proceedings were valuable aids to fair discussion. With a reverence for the past, he united a sympathy with the aims and aspirations of the present, and he could understand and appreciate the necessities of an age of progress. 


\section{SIR JOHN LENNARD}

To this was added a sincerity of purpose, a disinterestedness of aim and a charm of personality which went far to account for the exceptional position he occupied. His power of will and mastery of himself were shown by the way in which he overcame the difficulty of a slight impediment of speech, which, in many men, would have been a serious disability. In his case it appeared to his hearers little more than an effort to select the word most suitable to the occasion -for he never allowed himself to be hurried-and at public functions no one could give more graceful and felicitous expression to the sentiments of those of whom he was the mouthpiece.

The late Sir John Lennard was another admirable instance of the disinterestedness with which a representative of the much-abused landowning class recognized and fulfilled the responsibilities of their position. Like Sir Richard Paget, he was indebted to the Army for his training, and like him, he was in the very forefront of his county, viz., Kent, being chairman of Quarter Sessions and the County Council, besides holding many other official positions. He was a vicepresident and trustee of the Bath and West Society, and, having a remarkable knowledge of farm stock, of which he was a noted breeder, it was to this department of its work that he specially devoted himself, undertaking the onerous duties devolving upon the chairman of the Stock Prize Sheet Committee and Senior Stock Steward. In both capacities he was indefatigable, and, though a strict disciplinarian, he was much liked by both exhibitors and their employees, for, as a successful 


\section{FIFTY YEARS OF A SHOWMAN'S LIFE}

breeder of pedigree-stock, he had a practical acquaintance with their difficulties, and so could make allowances for them. At the same time, he never permitted anyone to play fast and loose with rules and regulations, which, as he would say, "are made to be upheld." Anyone who thought Sir John could be trifled with in this respect soon discovered his mistake, for, however gentle his accents - and they were seldom otherwise-there was a reserve of quiet force behind them which took some reckoning with. He was always open to argument, but when once he had made up his mind on a point, he knew, as an old soldier, how to stand to his guns. In his department, he looked after the interests of the exhibitors as well as those of the Society, and, if he found a servant neglecting the stock in his charge, he would give the offender a very bad quarter of an hour.

From morn till eve, in sunshine or in storm, he was always found at his post in the show yard, intent upon the work of his department. He would thus be on his legs all day-this was the case even when he was 83 years of age-and the amount of walking and standing about he would undergo without complaining of weariness made many a younger man marvel. If he showed any signs of fatigue at the end of a particularly hard day, he would say, with a confident smile, "A night's rest will soon put that all right." It invariably did, and the next day he was up in the yard betimes, as bright and fresh as the youngest of his colleagues, and with much of the cheerful light-heartedness of a schoolboy out 


\section{A GOOD ALL-ROUND SPORTSMAN}

for a holiday. No doubt his powers of endurance were greatly helped by his methodical and regular life, for he was extremely abstemious, and having laid down a rule for himself was careful to observe it. Physically and mentally, therefore, he seemed always fit, and to no one could the description mens sana in corpore sano be more truly applied. The cheery optimism with which he always made the best of everything was a help to others beside himself.

To a great extent his work was his recreation, but he was a good all-round sportsman, a capital shot, and a thorough judge of horse-flesh. He especially delighted in hunting, and was one of the oldest followers of the West Kent and Old Surrey Hounds. Although he enjoyed it as much as ever, when he was well over eighty, he so far deferred, though reluctantly, to age, as to hunt only about once a fortnight instead of, as in previous seasons, three days a week. It was said-and it would be thoroughly characteristic of him - that he at once increased his public work as a recreative compensation.

Lofty in his ideals, stern, almost, in his uprightness, he was, withal, the most lovable of men. As a correspondent, who knew him well, wrote: "He was my idea of what an English country gentleman should be, bold, and strong and gentle." 


\section{CHAPTER XV}

Cider Making at Home and Abroad-A Voyage of Discovery-The National Fruit and Cider Institute.

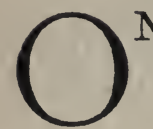

$\mathrm{NE}$ of the most useful of the many investigations undertaken by the Society on behalf of agriculture was that which dealt with the manufacture of cider, an industry which, in view of its importance, had previously been strangely neglected, for of all the operations of farming not one was so little understood. Much of the cider made at the farm was undrinkable except by those who were endowed with cast-iron interiors inherited from previous generations of cider drinkers, who thus became habituated to extremes of acidity. So far as outsiders were concerned, if they could only have viewed the process of making and the varied ingredients, other than apples, which had a part in compounding the beverage, they would have foresworn cider for the rest of their natural lives. Cleansing the fruit was too often considered quite an unnecessary trouble even after it had lain in an orchard frequented by the pigs and poultry of the homestead. Rottenness in fruit was not regarded as a valid reason for rejecting it for cider, and it was a long-established tradition that good cider fruit was not fit to eat, whereas, whether 


\section{EDUCATION IN CIDER-MAKING}

for the making of either sweet or dry cider, the more saccharine the fruit possesses the better.

These were ingrained misapprehensions, which it required the stern logic of proof to the contrary to refute, and this task the Society set itself to accomplish. There has been plenty of so-called cider made in this country and America without one drop of apple juice in it. Some time ago two firms were proceeded against by the Board of Agriculture under the Merchandise Marks Act, when the evidence showed that the beverage sold as "sparkling cider" was made out of chemicals and colourings, sugar and flavourings; anything of the nature of apple juice being conspicuous by its absence. Both firms, who were manufacturing this drink on a large scale, were convicted; the quite inadequate penalty of $£ 5$ being imposed in each case. However, the costs in addition mounted up to $£ 20$ apiece.

I am not suggesting that up to this time there was no good cider made, because there were enterprising manufacturers who took advantage of improved methods and up-to-date machinery, and so produced a very different article from the ordinary farm cider. But, until the Bath and West Society took the matter in hand, there had not been in this country any systematic and recognized effort to make good cider on scientific and hygienic principles in contradistinction to that rule of thumb, which for long had held sway -and is not yet entirely discarded-in most farm-house operations.

The first thing was to offer encouragement to cider makers by giving the industry a status in 


\section{FIFTY YEARS OF - A SHOWMAN'S LIFE}

the show yard. So classes for cider were instituted and accorded a permanent place in the Society's prize list. The late Mr. F. G. Farwell, the Society's indefatigable steward of cider, and myself, after visiting several cider exhibitions, came to the conclusion that the system of exhibiting should be made much more educational. Rows of casks and bottles, whether labelled as prizewinners or not, told the public nothing worth knowing, except that either Brown, Jones, or Robinson had been awarded, or not, a prize. Other cider-makers, desirous of profiting by the experience which led to the manufacture of cider good enough for a prize, had no basis to go upon when no particulars were supplied. In order to remedy this the Society now required every exhibitor to accompany his entry with full particulars as to the description of apples used, the nature of the soil on which the fruit was grown, and other information likely to be helpful. This was then copied on to cards, which were attached to each exhibit for the information of the public. The steward further undertook to be in the cider pavilion each day to be interveiwed by cidermakers, who were supplied with tasting orders, so that they might, after sampling, judge for themselves as to the merits of the various exhibits. This resulted in informal gatherings at each show of a most useful and instructive character. A further step taken by the Society was the collecting of samples of all the best cider-making apples. Water-colour drawings of these were then most carefully executed, and the apples, having been analysed, a statement of their chemical composition, 


\section{"THE BUTLEIGH SQUIRE"}

with other details as to name, where grown, nature of soil, etc., was attached to each drawing. These drawings are always exhibited at the Society's show, where they attract much attention, and at other times can be seen at the Society's Bath offices.

There was a further very desirable innovation, which provided that before being judged every exhibit of cider should be analysed by the Society's analyst, and whenever any preservative is found in it, as not infrequently happens, it is at once disqualified; particulars of the analysis, in any event, are attached to each exhibit.

In 1893 the Council was enabled to put their ideas, with respect to improvements in cidermaking, into actual practice, through the liberality and public spirit of Mr. R. Neville. Grenville, of Butleigh Court, Glastonbury, a vice-president of the Society, who, having placed premises, machinery, and apples at the Society's disposal at Butleigh, for the making of cider, followed this up the following year by erecting there a laboratory or experimental station, so that practice and science could go hand in hand. Here for a succession of years, and until the National Cider Institute was founded, a valuable series of experiments was carried out in connection with every branch of the subject, under the direction of Mr. F. J. Lloyd, F.C.S., F.I.C. All interested in the industry were invited to visit the station and see for themselves the advantage of calling in science to the aid of practice. Large numbers of cider-makers and farmers availed themselves of the opportunity to learn how far improved methods 


\section{FIFTY YEARS OF A SHOWMAN'S LIFE}

and appliances could help them, and brought with them many problems in manipulation which had previously baffled them, in the hope of the Society's experts finding a solution of them.

The Society's Council were not content with such information regarding cider-making as was obtainable in this country, and were desirous of ascertaining in what respects the methods adopted abroad, in connection with the cultivation of cider fruit and the manufacture of the beverage, differed from those pursued in our own country. Nowhere is cider-making pursued with more thoroughness and enterprise or with a keener appreciation of the importance of the industry than in Normandy and Brittany. So, as the Pomological Society of France, one of the most important representative associations of its kind, was holding its Annual Exhibition and Conference in 1895 at St. Brieuc, I communicated, by direction of the Bath and West Council, with the French Society, expressing the desire of the Council to be represented at its meetings. There was a very cordial response to this conveying a full assurance that any representatives the Council might send would be heartily welcomed, and I may add that this promise was more than fulfilled. Accordingly, Mr. Neville Grenville, the late Mr. F. G. Farwell (the Society's cider steward), Mr. F. J. Lloyd, and myself were deputed by the Council to attend the exhibition and meetings, which were held on October 17th, 18th, 19th, and 20th, with a view to picking up all the information we could. Aboard the boat which took us across were the late Mr. Radcliffe Cooke, M.P., the Founder and President 


\section{POMOLOGICAL SOCIETY OF FRANCE}

of the National Association of British Cidermakers, who had done a good deal by his writings and in other ways, to promote fruit culture and to popularize cider in this country, and his secretary ; and, as they were on a similar mission as ourselves, we joined forces.

The Pomological Society of France has, for its main object, the promotion of everything tending to assist and improve the cultivation of apples and pears and the manufacture and sale of the beverages obtained therefrom. It has a large number of members, among whom landowners, farmers, nurserymen, manufacturers, and labourers are all well represented. It holds an Annual Exhibition and a Conference, which take place each year in a different district. Prizes, consisting of works of art, medals and diplomas, are then offered for trees, fruit, beverages, machinery and appliances, and also for nurseries located in the district in which the exhibition is held. Beyond this, the Society, by conducting practical and scientific research, and by publishing the results of its investigations, does much to stimulate the industry it represents.

The exhibition in question possessed several remarkable features, and is so good an example of the thoroughness the French bring to bear with respect to rural industries that $I$ think it may be both useful and interesting to give a summary of our experiences in Brittany. On the advent of peace the English country-side and those belonging to it will occupy a much more prominent position in the public estimation than they have hitherto done, and there will be a far greater disposition 


\section{FIFTY YEARS OF A SHOWMAN'S LIFE}

in the future than there has been in the past to consider the subject as of national importance. This being so, we shall have much to learn from the French.

St. Brieuc is a little town in Brittany of about 20,000 inhabitants overlooking the English Channel. It is situated in the centre of a large cider-making district, iron and steel works being its chief industry. 'It is a most delightfully quaint old place, and, with its narrow streets, picturesque architecture and generally old-world look, reminded one of what an English town must have been like in the middle-ages. It boasts a cathedral and several churches, all of ancient origin, and all possessing many interesting architectural features. Yet, although the place affords abundant materials for the artist, and has qualities attractive to the ordinary tourist, the outside world seems to pass it by. This is due in a great measure to the fact that it does not do anything -or, at any rate, it did not at that time-to exploit itself. There were no guides, no photographs, or anything that would help to convey the impression that it was a place well worth visiting.

The exhibition of implements and appliances was held in a fenced-off portion of the Champ de Mars, a large open space, used for drilling purposes, in front of the barracks, St. Brieuc being a garrison town. The smaller exhibits were under shedding, the larger ones being shown in the open. As the weather was beautifully fine there was no disadvantage in the latter arrangement, but, had it been wet, it would have been attended with much inconvenience. 


\section{A TRULY EDUCATIONAL EXHIBITION}

The exhibits of fruit and beverages made from it were staged in the extensive buildings forming the Municipal Schools. No less than 3,150 plates of fruit, each plate containing ten specimens, were exhibited. Some of the apples measured as much as from 13 to $14 \frac{3}{4}$ inches in circumference, and weighed over $18 \mathrm{ozs}$. To illustrate the thorough manner in which the people are educated to realize the importance of detail concerning the fruit they grow, I may say that exhibitors had to fill up a printed card for each variety exhibited, particularizing the characteristics of the tree at various stages of growth and also of the fruit, the nature of the soil, situation, etc. The card is subsequently placed alongside the plate on which the fruit is exhibited, so that visitors are put in possession of what is known concerning its growth and characteristics. The advantage of these details was brought home to us when we observed several country people taking apples from their pockets and comparing them with the various fruits exhibited until they could identify the sort, when they made notes of the names and qualities for future use and reference. The exhibitors sometimes supplemented the information given on the card by adding drawings of the trees and plans of the orchards, specifying the exact trees from which the samples exhibited had been taken. In judging, from 1 to 25 points were awarded for the information given on the cards; from 1 to 25 points for the appearance of the exhibit; from 1 to 50 points for the density of the juice. This latter was ascertained at the show, the apples being ground and pressed for the purpose. Mr. Lloyd was

$$
159
$$




\section{FIF'IY YEARS OF A SHOWMAN'S LIFE}

appointed one of the jury to take the density of the juice obtained from the exhibits.

The liquids, which were exhibited in the same buildings as the fruit, consisted of cider and perry in bottles and casks, and also of eau de vie manufactured from apples. Some specimens of liqueur which had been made from cider spirit were also shown, but these were not for competition, being merely examples of the use to which cider spirit was capable of being turned. No exhibitor was allowed to show any liquid not the product of his own fruit or manufacture. Opportunities were given for those who were known to be really interested in the production of cider to taste the exhibits, and a free and lively discussion was continually taking place as to their relative merits. In the conditions, as above-stated, governing the exhibition, we found points of detail of which we were glad to take advantage in connection with our Bath and West Show.

Prizes were given for collections of, at least, six apple or pear trees grown for cider or perry respectively, and for six seedlings raised from the same. Prizes were also offered for the best nurseries in the surrounding district of St. Brieuc.

At 8.30 each evening a conference was held at the Hôtel de Ville, at which several hundred people were present. Papers were read, and animated discussions took place with reference to the cultivation of cider fruit, the manufacture of cider, and the legislation affecting it. These meetings were thoroughly practical in their character, and afforded admirable mediums for the interchange of opinions upon matters closely affecting the 


\section{ALCOHOL IN CIDER}

interests of the industry under consideration. They were attended by landed proprietors, farmers, manufacturers, and heads of educational institutions, and the keenest interest was shown in all the proceedings. If a subject were broached, upon which there was evidently great divergence of opinion, instead of continuing a heated debate the matter was at once referred to a committee, appointed by the meeting, to consider and report thereon. When possible the committee met early next day and presented their report at the conference in the evening. One of the most important questions discussed was raised by the Mayor of St. Brieuc: What percentage of alcohol should genuine cider contain? It was brought forward with a view to putting down, if possible, a custom, which was thought to prevail, of manufacturers buying genuine cider from the farmers, and diluting and otherwise tampering with it before reselling. Owing to the difference of opinion which was expressed the subject was referred to a committee, who reported that cider should contain at least 4 per cent. of alcohol, and this conclusion was accepted by the conference.

The awards of the juries for each section of the exhibition were announced, and the prizes and certificates were presented at a meeting of the conference held in the afternoon of the last day of the exhibition. The final meeting took place the same evening, when a vocal and instrumental concert with recitations formed part of the proceedings.

The French Pomologists held in very high estimation the service rendered to agriculture by 


\section{FIF'IY YEARS OF A SHOWMAN'S LIFE}

the Bath and West Society, especially in connection with cider-making, and many complimentary references were made to this at the conference. On the motion of the chemist of the Pomological Society (Monsieur E. Morio) a gold medal was awarded by the Society to Mr. Neville Grenville for having instigated and promoted improvements in cider-making, and a similar medal to Mr. Lloyd in recognition of the research work he had accomplished. Monsieur Morio gave particulars of Mr. Lloyd's observations, as recorded in the Bath and West Society's Journal, and said that they had thrown a new light upon many points connected with the manufacture of cider.

The French Pomologists, having concluded that the State-as would have been the case in France-would have been sure to have recognized Mr. Neville Grenville's public spirit and generous assistance in promoting so important a matter, always addressed and spoke of him as Sir Grenville, and I don't think he ever succeeded in convincing them that he had no handle to his name. They certainly did their best to rectify the omission by themselves according him one.

Opportunities were given us-of which we were glad to take advantage - to visit some of the principal orchards and nurseries in the district. The orchards of Brittany are very different from those of England, being mostly on arable land instead of on grass. The arable land is deeply cultivated, and carries a rotation of crops, special attention being given to the manuring of the land.

Most of the farmers know the names of the apples which they grow, and, thanks to the 


\section{A MODEL SCHEME OF EDUCATION}

influence and teaching of the Pomological Society, are becoming acquainted with the conditions affecting the growth and composition of the fruit. This information they obtain partly from specimens and partly from the schools in each district, and we were particularly struck by the great interest shown in the work of the Society by all the scholastic, ecclesiastic, and landed interests of the neighbourhood.

Near St. Brieuc, we inspected a manufactory of cider, attached to a large college, dedicated to St. Charles. Here we were met by several of the officials of the college, who very courteously explained the method of manufacture adopted, and described the machinery used. As the drink of the scholars, who number some hundreds, is mainly cider, a considerable quantity is made annually for their consumption.

Endeavours are made, and successfully, to interest the heads of educational institutions in the meetings of the Pomological Society, and among the school instructors who take a special interest in the Society's work are those known as "Les Frères de l'Instruction Chrétienne." Their schools, which appear to be conducted somewhat on the same lines as were our National Schools on the voluntary system, make agriculture one of their five primary subjects of education. As was pointedly stated by le Frère Abel, who is an active member of the Council of the Management of these schools, and also a vice-president of the Pomological Society, "We teach our scholars first to be Christians, and, secondly, how to earn their livelihood." 


\section{FIFTY YEARS OF A SHOWMAN'S LIFE}

In the preface to the agricultural primer used in these schools, reference is made to the fact that the population of the country is practically drifting towards the towns, and it is pertinently asked: "Is it not the duty of every man concerned in the well-being of his country to educate the young to fight against these false ideas, and to establish in the minds of the children a love of the country and of rural prusuits?" It is further observed that, "in order to give children country tastes and encourage them to understand and love agriculture, we teach them at school such subjects as may interest them in and attach them to the land."

It is a pity that in our own rural elementary schools some similar course of instruction is not adopted. We teach the children by pictures what a lion or a whale may be like, in case they should meet either of them on their way home from school; but we do not teach them the difference between turnip-seeds and charlock, how to graft or prune, or any of the hundred-and-one different subjects which would make agricultural life more attractive to them, and help to retain them on the land.

One could not fail to be struck with the prominent part played by the Church in all the proceedings. The village priest was in evidence everywhere. He it was who organized and controlled the village associations, which collected and arranged the exhibits sent up for competition to the meeting of the parent Society. Then he shepherded his flock, and personally conducted them to the exhibition, improving the occasion 


\section{FRENCH COURTESY}

by making the round of the show with them, in order to point out and explain what they ought to observe. He was also well represented on the governing body of the Pomological Society, and was a live factor in all that concerned it. This was good evidence that, although the State had disowned the Church, the people themselves had by no means foresworn it. Additional evidence of this was supplied in the official recognition of the spiritual side of life, by means of a special service at one of the churches, which was attended by the Society's officials and many others, including the Bath and West representatives.

I must pay tribute to the very hearty welcome which, as the Society's representatives, we received from our French confrères, and from all with whom we were brought into contact. The utmost cordiality was shown to us, and all possible facilities were forthcoming to enable us to see and learn everything relating to the object of our visit. To this end, we were appointed honorary members of the adjudicating body, and were presented with badges similar to those worn by the Council of the Pomological Society, so that we might enjoy corresponding privileges of access to the various departments of the exhibition and conference. There was no attempt made to conceal anything, and we had only to express a desire to visit an orchard or a manufactory to find that arrangements were made for us to do so, and that a willing conductor was at our disposal.

We were also most hospitably entertained by the president of the Society and others connected with it, and these and similar opportunities 


\section{FIF'YY YEARS OF A SHOWMAN'S LIFE}

facilitated an interchange of thoughts and experiences which was very helpful.

It need hardly be said that our visit was full of suggestiveness, and that we brought away with us much information well worth going over to the Continent to obtain. It enabled the Society to develop and improve upon the methods it had already adopted, both our own and the French Society having the same end in view: to make the work upon which each was engaged as educational as possible.

It is worthy of note that this visit occurred at a time before the institution of the entente cordiale, and when there was friction in the foreign departments of both countries. At that very moment English newspapers were saying that so strong was the feeling in France against our countrymen that they had better take holiday elsewhere, and were complaining of studied discourtesies offered to English travellers. Yet we experienced nothing but the kindest consideration and a most evident desire to make our stay as agreeable and as useful as possible.

The Society, having carried on its practical and research work in cider-making for some years, and having shown the Government and the country generally how an admitted want could be met, joined with the State and various public bodies, representing fruit-growing and cidermaking counties, in establishing the National Fruit and Cider Institute at Long Ashton, where, under the direction of Prof. B. T. P. Barker, M.A., and a staff of experts, experimental and research, as well as practical, work, is actively 166 


\section{ANNUAL GRANT}

carried on to the great advantage of the industry. The operations of the Institute were a few years ago still further extended by its attachment to Bristol University. The Bath and West Society makes an annual grant of $£ 100$ in its support, and the Society's annual Journal is the medium for. publishing the latest developments and discoveries resulting from the investigations referred to. 


\section{CHAPTER XVI}

A Show Yard Idyll-The Sunday Service-The Power of Human Sympathy-The Y.M.C.A, in the Show Yard.

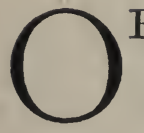

F course, the herdsmen and shepherds who are to be found in a show yard are mostly of a superior type, and necessarily so because they have the care of very valuable animals requiring experienced and trusty attendants to minister to their wants and generally to keep a watchful eye upon them. How well and conscientiously these duties are performed, and how well-conducted a body of men are those who perform them, anyone connected with show yards can testify. A little show yard story seems worth a place among my recollections, because it is some testimony to the character of the men of whom I have been speaking.

It happened thus. Two days previous to the opening of the Bath and West Show at Newport (Mon.) a little lad-a town waif-very ragged and ill-shod, obtained admission to the show yard by concealing himself among a waggon load of sheep, so escaping the notice of any gate-keepers. It was adventurous to say the least. When in the yard he seems to have justified his presence there by making himself generally useful, and soon earned a character among the stockmen of being "a real handy lad." The men, taking quite a fancy to him, not only let him remain with them, 


\section{SOME GOOD SAMARITANS}

but generally cared for him in quite a fatherly way. At the end of the week, when the show was approaching its termination, these kind-hearted shepherds-they were mainly those looking after the Shropshires and Hampshire Downs-began to bethink themselves what else they could do for the boy, for they did not like to leave him the tattered and forlorn waif they found him. They might have fallen back upon the rates to do anything further, and have told him to go to the workhouse. They did nothing of the sort, however, but they had a whip round among themselves, quite in a quiet and unostentatious way, and thus collected twenty-three shillings; no small sum when one considers the means of the donors, and the fact that there was no published subscription list to trumpet their good deeds abroad. Their charity, moreover, was thoroughly practical. They did not pour their little collection of coins into the boy's lap, heedless of what he might do with them, and with the feeling that they had behaved handsomely and had no further responsibility in the matter. They were willing to give time and trouble besides money, so they spent the latter in the best possible way by escorting the lad to an outfitter's and providing him with a complete rig-out. Beyond this, one of the shepherds offered, if nothing better were forthcoming, to take him back with him into the country in the belief that he could find him a situation there.

During the quietude of the Sunday in the show week, when the yard-in contrast to the scene of bustle and excitement it presents on other days - is one of the most reposeful places I 


\section{FIFTY YEARS OF A SHOWMAN'S LIFE}

know, I was dilating upon the circumstances I have been narrating to one of the Society's stewards. $\mathrm{He}$ is a real good worker in this capacity, although a member of that hereditary branch of the legislature which has had hard things said about it. I knew he would be a sympathetic listener, and we were in mutual agreement as to the practical Christianity which the episode represented. "But," said he, "I can add to that story," and he then told me that, as in company with other stewards, he passed by the stock lines early that morning, he heard a little commotion, and saw a group of stockmen round one of the stand-pipes for supplying water for the stock. In the midst of them was the waif, being thoroughly well-washed and scrubbed by his good friends. They-practical all throughwere not going to put him into a brand-new suit and render him presentable only on the surface. They determined to make a real good job of it right through; hence this ablutionary discipline, and, as one of the party remarked, "he wanted it badly," which I can quite believe. Having now put him into a condition that enabled him to hold up his head among his fellow-creatures, these country-side Samaritans brought the object of their solicitude to the Sunday service, which for so many years has been held in the yard on the Sunday in show week, and thereby, with this evidence of their thought for his spiritual as well as bodily welfare, placed the capping stone upon their work.

The sermon was preached by the Bishop of Llandaff, and, as I was escorting his lordship up the yard to the service, I could not resist telling 


\section{THE BISHOP AND THE BOY}

him the story I have told my readers, for I was a bit proud of the sort of men we had in our yard. He was so pleased with the incident that, to the astonishment of those, "who do good by stealth and blush to find it fame," he made the following reference to it in the course of his address: "Since coming on the ground this afternoon I have heard a pretty and touching story of the care and kindness you have shown to a little wanderer who has come across your path, and this act has proved you to be men of generous, kindly sympathy, and men of big and kindly hearts." I think we must agree that the bishop had a justification for his tribute. His lordship afterwards interviewed the "new boy," no longer a mere waif, and also two of his sponsors, and it was pleasant to hear the good character they gave their protégé and of their desire to keep him if possible in his present improved condition. I may add that others interested themselves in him, and so the singleminded, disinterested kindness of which I have written bore more fruit in the end than could have been anticipated.

This was not an abnormal instance of show yard benevolence, for it is by no means uncommon, if a stockman comes to a show ill-clad and lacking the wherewithal to repair this, for his fellows to subscribe privately among themselves for the betterment of his condition.

The service referred to has always been a pleasant feature of show week, and it is something to be thankful for that, without any pressing to come and entirely of their own free-will, the large majority of the herdsmen, shepherds, grooms, 


\section{FIFTY YEARS OF A SHOWMAN'S LIFE}

etc., on duty in the yard make a point of attending it. It is a very simple, hearty service-an abbreviated version of Evensong, with specially selected Psalms and lessons-which is joined in by many Nonconformists as well as Church-folk. To enable all to follow it, it is put into print, copies being distributed to all who attend. The Society's chaplain conducts the service, assisted by the vicar or rector of the particular parish in which the show is held, and the address is usually given by the bishop of the diocese. The singing is led by the parish choir with the help of a harmonium, and it is delightful to hear the heartiness with which the country-side folk sing "The Old Hundredth," "O God, our help," and "We plough the fields and scatter," and with a spirit and appreciation betokening intimate familiarity with both words and music. The Society's stewards act as churchwardens and vergers and as readers of the lessons. In my own time, this latter duty usually devolved upon the late Sir John Lennard, after him upon the late Lord Wynford, and at his death upon the present holder of the title; singularly good readers all of them. The service has of late years been held in the Working Dairy, the large floor space of which affords full accommodation for all taking part in it.

A big show yard is a little world in itself; all sorts and conditions of men, as well as animals, find a place in it, and I have never known a show, out of the many with which I have been associated, that did not furnish some incidents worth recording on account of the pleasant light they shed upon 


\section{A KIND-HEARTED STEWARD}

human traits. The close intermingling of those in very varying positions in life is, in itself, an unmixed advantage, leading, as it does, to a better understanding and appreciation of the objects and methods of each, and to a common sharing of trials and difficulties. There are all kinds of opportunities for the exchange of little courtesies, for doing neighbourly turns, and for helping lame dogs over stiles.

Illustrating this, I will venture upon another story, which shall be a short one. For the better supervision of the yard, several of the stewards of departments sleep in it just before and during the show, a row of timber-built bedrooms being erected and furnished for their use. At several of our shows a stock steward inhabited one of the little huts reserved for those whose devotion to duty induced them to spend the nights as well as the. days in the yard, and so he was in constant communication with the many herdsmen and others looking after their employers' animals. He had a handle to his name, and had formerly commanded the crackest of crack regiments, but that he was no military martinet was evident from the feeling with which he was regarded by those subject to his orders in the show yard. In a quiet sort of way, he had interested himself in looking to the general comfort of the stockmen, and, when regulations had to be enforced, his tactfulness conciliated opposition. On the Saturday before the close of the show, as the colonel was unsuspectingly looking round the cattle lines in the early morning, seeing that all was shipshape and in order, a little deputation 


\section{FIFTY YEARS OF A SHOWMAN'S LIFE}

approached him. Its spokesman handed him a letter, written in a very bold hand, and in the homely phraseology to which those whose sentiments it conveyed were accustomed, setting forth how grateful they were for the kindness and consideration he had shown them. Then a parcel was put into his hand with the expressed hope that he would accept it as a memento of their appreciation of his thought for them, and the colonel suddenly found himself in possession of a case containing two silver-mounted pipes. He assured me that he had never received anything he valued more highly than that letter, and I am sure he meant what he said. The magic of human sympathy is, happily, still a power in the land, and can elicit a responsive echo.

I am glad to say that more regard than formerly is now shown for the general welfare in a show yard of those in charge of the animals and other exhibits which find a place there, inasmuch as at the Bath and West Society's shows space is allotted for the erection of a reading and writing tent for their special use, and here evening meetings, concerts, etc., are held. This was due to the initiation of the Young Men's Christian Association, who were the first to take steps to meet this want, and have ever since supplied it, with the full support of the Society's Council. When the proposal to admit the Association to the yard was first made some fears were expressed that to accord a status at the show to an organization unconnected with the Society might give rise to difficulties. I ventured to urge that the experiment might be tried for one show. This was done 


\section{THE Y.M.C.A.}

with undoubted success, and the relations between the Society and the Association were then, and have been ever since, of the most amicable and harmonious character, whilst the value of the innovation, as supplying a distinct want, was fully recognized. The knowledge I thus acquired of the aims and methods of the Association brought home to me the value of its work, and later on was a factor in inducing me, so far as I was able, to lend a helping hand by taking an active interest in the Bath Branch as its president. Those for whom the accommodation in the yard is provided make good use of it. On the occasion of its first introduction one of the herdsmen said that he had attended shows for twenty-five years, and had never before written home during a show, but that when he found pens, ink, and paper ready to hand, and a suitable place in which to use them, he sat down on the Sunday and wrote to his children. Newspapers, magazines, stationery, games, etc., are provided free of cost to the users, and the tent has many of the conveniences and attractions of a social club. I hope such an institution will always find a place in the Society's show yards.

Since writing this chapter, I have received, as a memento of the kind-hearted steward, a handsome silver cigarette case, with the following inscription: "Presented to Col. the Hon. C. Byng by the Shorthorn Herdsmen at the Bath and West Society's Show at Newport, 1907." Knowing the colonel's horror of anything suggestive of selfadvertisement, I have abstained from disclosing his name until now. 


\section{CHAPTER XVII}

"Gee-up, Dobbin "-Topics of Yesterday and To-day-Coke of Norfolk -Hands Across the Sea-Benjamin Franklin-An Historic Letter.

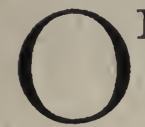

$\mathrm{NE}$ of my treasured possessions is a massive silver cup, ornamented with various agricultural emblems, and inscribed

"Awarded to Mr. Joseph Plowman for his essay which gained the first prize offered by the Oxford Farmers' Club, 1855." The subject of the essay was "The advantages resulting to the public in general and to agriculturists in particular from Farmers' Clubs and other agricultural associations." The adjudicator was Dr. Daubeny, the Professor of Botany and Rural Economy in the University of Oxford. My father had appended to his composition-as the name of the competitor was not to be revealed till after the award had been made - the characteristic signature of "Geeup, Dobbin." I very well remember his coming home with the cup after it had been presented to him by the President at the Club dinner and rejoicing with him at its acquisition. Thirty years after 'this the London Farmers' Club requested me to give them a paper on "Agricultural Societies and their Uses" for their meeting in Smithfield Week. Times and methods had altered 


\section{THE FARMERS' CLUB}

so much in those thirty years that I could not find a single sentence in my father's essay that furnished me with any useful argument for my own case, which was a good thing, as it left me to deal with the subject from the standpoint of my own personal experiences. I did not confine myself to the show side of agricultural societies, but brought Farmers' Clubs, Chambers of Agriculture, Breed Societies, and other organizations within the scope of the paper. "It resulted in a very interesting and animated discussion, in which such practical representatives of the national industry as the late Lord Jersey, Jas. Howard, Clare Sewell Read, H. M. Jenkins (Secretary of the Royal Agricultural Society), John Treadwell, Major Craigie, Sir Walter Gilbey, and other shining lights took part. I had several contentions to meet in my reply, but nothing that, according to my own reckoning, I could not fully answer. In 1855 my father's health, as the reader of the prize essay, was duly honoured and responded to at the annual dinner of the Oxford Club, and in 1885 history repeated itself, for, on the night after the reading, I was on my legs at the London Club dinner following my father's example, though I have no silver cup to show for it. However, I was well-content with such kudos as the agricultural world and its press were good enough to bestow upon me.

Later on, at the beginning of the present century agricultural societies and their methods were a good deal criticized, furnishing texts for many discourses in the public press and elsewhere. It used to be said that every man could, or thought 


\section{FIFTY YEARS OF A SHOWMAN'S LIFE}

he could, "drive a gig, poke a fire, and edit a newspaper," but, judging from the many opinions upon the subject then confidently expressed by all sorts and conditions of men, there appeared to be a prevailing impression that the management of an agricultural society must be included among those accomplishments which come naturally to every one. Under these circumstances the Farmers' Club asked me to take up the cudgels once more on behalf of the cause in Smithfield Week of 1904. Appreciating the compliment, I willingly complied. This time I treated the subject from a different standpoint to that I adopted on the previous occasion, and took as the title of my paper, "The Policy of the Show Yard and its Administrative Methods," which, narrow. ing the area, enabled me, as an old showman, to go much more fully than before into questions of management, and offered opportunity for adumbrating a policy of future development. On this occasion I boldly declared myself as the apostle of a policy of expansion and cosmopolitanism, which took count of town as well as country, on the lines $I$ have indicated in previous chapters. Lord Jersey repeated the kindness he showed me when I previously read a paper to the club by moving the vote of thanks to its author, which was followed by a very practical discussion, contributed to by several leaders of agricultural opinion at that time.

On the death in 1890 of Mr. Josiah Goodwin, the Society's editor, I was unanimously appointed to succeed him, with Mr. F. J. Lloyd as my associate editor. 


\section{THE ANNUAL JOURNAL}

With the Council's concurrence, certain improvements were then carried out with respect to the general production and arrangement of the Journal, including the substitution of a good cloth binding for paper covers. This change was much appreciated, for it not only rendered the volume much more presentable in appearance, but resulted in its longer preservation on the bookshelves instead of its being consigned to the wastepaper basket, as was often the case when, in paper covers, it reached the untidy and dog's-eared stage.

Copies are presented to leading institutions on the Continent and in America and the Colonies, as well as in this country, and the communications which reach us from such sources afford good evidence of how much the Journal is read and appreciated abroad. If by any chance a copy miscarries, we receive urgent requests for its replacement, and in several instances of late Colonial and American Institutions have gone to the expense of purchasing back volumes over a long series of years for the sake of the information contained in them. It is remarkable how strong is the desire on the part of the New World to be put into early possession of all that the Old World is doing for the promotion of agriculture, and this is particularly the case with regard to anything in the nature of scientific investigations and research work.

The Journal boasts a long pedigree, for the first volume, though under another title, was issued shortly after the foundation of the Society in 1777. Since that time it has numbered among its contributors nearly every agricultural writer of note from Arthur Young onwards. Although 


\section{FIFTY YEARS OF A SHOWMAN'S LIFE}

in these abnormal times, when service for King and country has claimed many competent penmen, and when agriculture, so far as the conditions of its pursuit are concerned, is very much in a state of flux, the Journal still goes on, though its issue is attended with more difficulty and expense than usual. The Society, however, has always borne in mind the advice tendered to it by Arthur Young, one of its earliest supporters :

"By all means publish your transactions; what you do is not for your own district alone, but for a much larger sphere. A Society that does not publish its transactions may be of a partial, limited and confined utility, but can never diffuse the knowledge it rewards, nor render the successful efforts the means of general improvement."

The literature, as well as the history, of agriculture repeats itself, and the Society's annals furnish many proofs that the burning topics of to-day are but revivals of those of yesterday. Like the poor, certain subjects seem to be always with us, for these volumes show that a century ago men's minds were occupied with regard to the potato disease, the turnip-fly, foot-rot, allotments, tithes, and other matters that find a place in the agricultural columns of to-day. Special subjects, too, were threshed out in the Society's publications long ago ; and even tobacco-growing in England, a topic which was regarded by many as possessing all the charm of novelty when it was re-introduced in our own time, had its possibilities discussed so far back as 1779, when the Society's committee appointed to consider it came to the conclusion that "the cultivation of that 180 


\section{EDMUND RACK}

plant does not appear to be an object which, under the present Parliamentary restrictions, can be of public utility." We seem to have progressed a little in this direction since then, as a company has been formed to exploit the industry in this country. Again, one of the subjects treated in the Society's Journal so recently as 1911 was the employment of oxen for draught purposes, and this same subject was discussed by the Society in 1784, when it was resolved to offer premiums to encourage the use of oxen in husbandry. Thomson, in his Seasons, written in the earlier portion of the same century, puts on record the then common practice in his lines referring to the approach of Spring :

"Joyous th' impatient husbandman perceives

Relenting Nature, and his lusty steers

Drives from their stalls, to where the well-us'd plough

Lies in the furrow, loosen'd from the frost."

The Bath and West Society was founded in 1777 by Edmund Rack, a native of Norfolk, who settled in Bath and took an active part in literary and other movements here. There was an interesting link during my own association with the Society, joining up the past of Rack's day with our own time, supplied by the late Sir Jerom Murch, long an old and active member of the Society's Council. In an article contributed by him in 1881 to the Society's Journal, he says :

"Everybody acquainted with that countyviz., Norfolk-knows how well versed its cultivators were, and still are, in farming matters. When I lived there sixty years ago Mr. Coke, afterwards Earl of Leicester, was enjoying a green 181 


\section{FIFTY YEARS OF A SHOWMAN'S LIFE}

old age in the midst of the beautiful farms he had created out of a vast rabbit-warren. I used to hear of the rides he took every morning before breakfast, now looking in upon one tenant and now upon another, each one prosperous in consequence of his own generous spirit and noble example. No theme was then more common than his annual sheep-shearings, at which Holkham was crowded by the élite of the agricultural world and by intelligent tenant-farmers, who, year by year, carried back to their homes incentives of the greatest practical value to "work and learn." "

Coke was born a year before Rack, and he died within the lifetime of Sir Jerom. So here we have a very interesting and long-drawn-out link with the past, for both Rack and Sir Jerom were Norfolk men who settled and died in Bath; both were closely identified with the Society and were contributors to its Journal; and, while one founded the Society, the other presided over it when the centenary of its birth was celebrated. The intervening space between two notable lives was bridged over by Coke, who joined the Society in Rack's time, and thus forged a chain connecting a distant past with a present, in which developments count far more than years.

A few years back I contributed a memoir of Rack, who was a very remarkable man, to the Society's Annual Journal (vol. viii., fifth series), and those interested in the subject of agricultural development at a time when many new principles and methods were in process of evolution will find many references to these in the memoir, as I had the Society's archives from its birth to fall back 


\section{LINKS WITH THE NEW WORLD}

upon. The Society has a contemporary portrait of its founder by Lewis Vaslet, a miniature painter of repute. It is executed in crayons, and has distinct merits as a work of art. It adorns the Society's Committee Room at Bath, and Austin Dobson must have had just such a costumed embodiment of the past in his mind when he wrote:

"He wears a brown old Brunswick coat,
With silver buttons-round his throat
A soft cravat: in all you note

An elder fashion."

My office post-bag often brings me pleasant reminders of the wide area over which the name of the ancient and loyal City of Bath is carried by means of the old Agricultural Society living in its midst. This is due to the fact that the Society, over a long series of years, has, by means of correspondence, exchange of publications, and in other ways, kept touch with many Agricultural and Scientific Societies on the Continent, in America, and in our Colonies. So far back as the latter end of the eighteenth century friendly communication had already been established between the Bath Society and distant bodies. Hanging in the Society's Committee Room is a framed diploma, dated November 30th, 1787, and signed by the Abbé de Lully, Comte Delgos, directeur, and the Abbé de Vitry, secretary, of the Société Royale d'Agriculture de Lyon, certifying that "William Matthews, sécrétaire de la Société d'Agriculture de Bath," had been elected an Honorary Associate of the Society they represented. An instance of the amicable feeling 183 


\section{FIFTY YEARS OF A SHOWMAN'S LIFE}

engendered by such inter-communications was afforded a few years ago.

The American Philosophical Society, one of the most notable of scientific associations, and which was founded a few years before the Bath and West Society, determined to celebrate, with much rejoicing and ceremony, extending over several days, the two-hundredth anniversary of the birth of its founder, the illustrious Benjamin Franklin. In token of a long and pleasant relationship, the American Society invited the Bath Society to join in its festivities by sending a representative to Philadelphia, where, at headquarters, the celebration was to be held. Some of our Council were kindly desirous for me to take advantage of the invitation, but-apart from other reasons-the anniversary, being in April, was much too near the date of our annual show to permit of my leaving with any sense of safety. But I cast about for something which might help to mitigate any feeling that the non-acceptance of so courteous an invitation was due to lack of appreciation of, or interest in, the subject of the celebration, and, happily, I lighted upon what I thought might serve. From my youth up I have been afflicted, or blessed-according to the point of view with which folk regard it-with an incurable craze for collecting the epistolary communications of eminent persons, and my portfolios are constantly yielding me something from their ancient stores, calculated to link up the present with the past. This sort of mania brings home to one that, after all, there is a good deal of continuity in this life, and that you 


\section{A BENJAMIN FRANKLIN RELIC}

cannot pack away in a box, as done with, the men and women who have preceded you upon the earth as though they were toy soldiers at the end of a day's play. But this, by the way. I knew that the great Benjamin's beautifully-neat caligraphy had an honoured place among my autographic mementoes, and in the good company of that of many statesmen and scientists of his acquaintance-few of whom, however, wrote as well as he did-and I welcomed an excuse for handling one of my treasures in the shape of the letter.

The letter was written at a most interesting juncture: just after the American Revolution had passed into the fighting stage. Franklin, who had been doing his best to rouse the Colonies against us, reported the result as follows in this letter :

"Dear Sir,

“Philadelphia, May 6th, 1775.

"I arrived here last night, and have the pleasure to learn that there is the most perfect unanimity throughout the Colonies, and that even New York, on whose defection the Ministry so confidently rely'd, is as hearty and zealous as any of the rest. I have not yet had time to collect particulars of information for you ; and, therefore, the chief intention of this line is to introduce to you the bearer, Captain Falconer, who is perfectly acquainted with the state of things here, and on whose accounts you may depend. With great esteem, I am, sir,

"Your most obedient,

"Humble servant, "B. Franklin.

"D. Hartley, Esq." 


\section{FIFTY YEARS OF A SHOWMAN'S LIFE}

Franklin, in the same year in which the letter was written, had returned from England, where for some time he had been acting as his country's agent, and was at once elected a Member of Congress. Events followed quickly after this, for, within a fortnight of the date of the letter, representatives of the Colonies had met and agreed upon Articles of Confederation and perpetual Union, and, on June 16th, Washington was appointed Commander-in-Chief of the American armies.

The David Hartley to whom the letter is addressed, was a distinguished Member of the British Parliament, a firm opponent of the war with the American Colonies, and one of the Plenipotentiaries who, at the end of the war, signed the Treaty of Paris recognizing American independence. Hartley lived a part of his time at Bath, published at least one of his numerous works there, and ultimately died there in 1813. He was the son of David Hartley, a physician of considerable eminence, who practised at Bath, and also died there in 1757. The elder Hartley had considerable literary ability, and occupied most of the time he could spare from his profession in the pursuit of science and philosophy; he was the author of the well-known metaphysical work, Observations on Man.

It occurred to me that if, in response to the invitation, I were to send the American Society a copy of this letter, with some indication of the value $I$ attached to the original, it might do something to show that we in the old country held the memory of their great founder so much 


\section{A FRATERNIZATION WITH THE U.S.}

in regard that we cherished any relic associated with him, even when it reminded us of an unfortunate episode in our nation's history. I debated in my mind whether I would not spare the letter itself, but I could not bring myself to this sacrifice; besides, as I speciously argued to myself, my reluctance to part with the original would be clear proof that we, in England, esteemed any memento of so illustrious an American too highly to let it go out of the country. So the copy was sent with the Bath and West Society's good wishes, and there came back a handsome acknowledgment, a testimony to the interest it was to the American Society, and an assurance that it would be allotted a place among the Society's archives.

How little did any of us then think that a few years afterwards England would have joined with America in celebrating "Independence Day" in a spirit of organized and genuine rejoicing.

My readers may, perhaps, care to know how the letter came into my possession, and it was in this wise. Some years ago, on collecting intent, I took an opportunity which offered itself at Bristol of acquiring a singular accumulation of old letters and documents, so many in number that until recently, when my physical activities have been curtailed, I had not had time to possess myself of an intimate knowledge of them. Among other letters, many of which were addressed or related to persons at Bath or Bristol, was this one, and David Hartley's connection with the West accounted for its presence in this company. In 1859 a large number of letters, addressed to 


\section{FIFTY YEARS OF A SHOWMAN'S LIFE}

the younger Hartley, and referring to the American War of Independence, were sold by auction in London, and many were purchased by an American millionaire, whilst others found a resting-place in the British Museum.

What a world of suggestiveness there is in an old letter like this! And what visions does it not call up of that first philosopher of his time, who was equally able, when the hour for action struck, to take his place in the foremost rank of his country's statesmen! Linked by the same chain of thought, there comes on the scene the great Chatham, who represented Bath in the Commons before his accessiou to the Upper House, impoverished in health, yet undaunted in spirit, using all the power of his fervent eloquence to rouse the British Government to a sense of the disastrous policy it was pursuing ! 


\section{CHAPTER XVIII}

Some Distinctive Personalities - Lord Redesdale - "Honest Lord Althorp" " The Colonel "-Lord Tredegar-A Trio of Workers.

T $\mathrm{N}$ view of their agricultural interest, I am tempted to add two other letters from my collection. The first is from John Thomas, second Earl of Redesdale, Chairman of Committees in the House of Lords, and, in the absence of the Chancellor, its Speaker. He was an admirable example of the fearlessly-honest Tory landowner of a past generation, who recognized that property had its duties as well as its rights, and acted accordingly. But he was something more than a country squire with an intimate acquaintance with all pertaining to rating and main roads, and one of the first of sportsmen, for he had a clearness of judgment and a grasp of detail that enabled him to exercise an enormous influence over the Private Bill legislation of the Upper House. He has been described as the Lord Dictator in all matters relating to railway and other schemes, and his shrewd, hard-headedness often frustrated the designs of promoters and directors of companies, for he enjoyed the confidence of the Lords to an almost unlimited extent. $\mathrm{He}$ had also no small reputation as a controversialist, and actively mingled in several ecclesiastical affrays. I remember him as the wearer 


\section{FIFTY YEARS OF A SHOWMAN'S LIFE}

of antique habiliments, of the country-side type, tail-coat and all, which revived memories of an older time. A letter to my father, dated April 16th, 1849, and referring to certain resolutions passed at a county meeting and forwarded to him by my father, when the recent repeal of the Corn Laws was agitating the agricultural breast, is, I think, sufficiently interesting in these latter days to be accorded a place here. It shows that his lordship was not so far behind the times as his opponents regarded him, inasmuch as we are now on the highroad to "a sound system of moderate import duties," whilst the malt tax has ceased to exist.

"Dear Sir,

"Batsford Park, April 16th, 1849.

"I am convinced that the true policy of this country is to be found in a sound system of moderate import duties, which, without excluding the foreigner from fair competition in our markets, shall subject him to contribute from the produce of his labour and land before it is sold in our markets some taxation in aid of those heavy burthens to which we in this country are subject, and which necessarily increase the cost of production. To effect this object all our exertions should, in my opinion, be directed. The only other expression in the second resolution which I desire to guard myself against being misunderstood upon is that which refers to the necessity of a great reduction in the national expenditure. I am in favour of every reduction which can be made consistently with honour, justice, and sound policy. I believe that no 190 
honest Englishman desires more, but as there are trading politicians who talk of much more, I do not wish to be classed with such.

"As regards the third resolution, I am in favour of the total repeal of the malt tax. I hold it to be a duty of which a war emergency could alone justify the imposition, and great agricultural and general prosperity the continuance even under such emergency. It is impolitic in its character, monstrous in its present amount, and most injurious to the farming interest and to the poor. I am, therefore, in favour of its total repeal, but am of opinion that in the present state of the revenue our demand should be for immediate reduction and total prospective repeal. It appears to me that in asking (which the Oxford petition does not) for immediate repeal the agricultural interest has for many years been led into an error which has caused them to fail in attaining their object. The amount of revenue derived from the present duties on malt is so large that no Chancellor of the Exchequer has dared to encounter the financial difficulty to be created by its repeal. I am convinced that if a firm demand had been made for its reduction, no Government could have long withstood so reasonable a request, and that the duty having been thus first brought to that amount which would have enabled a Minister to concede it without embarrassment at some time when there has been a flourishing revenue, it would ere this have probably been altogether repealed. As I believe that no interest is more injuriously affected than the landed by an empty and borrowing exchequer, 


\section{FIFTY YEARS OF A SHOWMAN'S LIFE}

I think it would be more politic now to proceed gradually (reducing the duty and supplying the deficiency so created in the revenue by new import duties) than to repeal the duty at once. At the same time, as it is impossible to fight an opposing Government on details of finance, and as my opinion is decidedly in favour of the ultimate total repeal of the duty in question, I should certainly feel myself at liberty to vote in favour of any general resolution in favour of its repeal, guarding myself as I have in this letter.

"The respect which I entertain for the farmers of Oxfordshire has induced me to state my opinions thus fully to their committee which has charge of the petition, and if they shall be satisfied to entrust it to my hands after the explanation above given of the sense in which I assent to the resolutions on which it is to be drawn up, I shall feel much gratified in being solicited by them to present it to the House of Lords.

"Trusting that they will excuse the errors of a very hastily written letter, I have the honour to remain, sir,

"Your obedient servant,

"Redesdale."

Few men have breathed the atmosphere of politics and come out of it with a purer record than he who has been handed down to posterity as "honest Lord Althorp," and who was the writer of the other letter referred to. Early in life he showed his attachment to agriculture, and, notwithstanding the claims of important offices of State, including the leadership, during exceptionally 
stormy times, of the House of Commons, he maintained his interest in farming throughout his career. On succeeding, as Earl Spencer, to a seat in the Upper House, on the death of his father, he retired from political life, and Cincinnatus-like devoted himself mainly to agricultural pursuits, becoming President of the Smithfield Club, and of the Royal Agricultural Society, of which he was one of the chief promoters. A letter of his in my possession is so characteristic in its plain-spoken directness, and so indicative of his practical knowledge and genuine and personal interest in his farm stock, that it seems worth including here. It is addressed to his agent, Thomas Bates, Esq., at Kirklevington, near Yarm, Yorkshire, and is dated and franked, from Leamington, on September 22nd, 1819.

"MY DEAR SIR,

"I think this is about as good a time for cattle to travel as any in the course of the year. The mornings and evenings are cool, and the roads are not yet become wet and dirty, in which state they are more likely to grind and wear the hoofs, just as a knife grinder wets his wheel to make it act quicker. For this reason (to say nothing about my own impatience to see the two cows) if Sparkler can be considered safe in calf I should like you to send her and Spot home. If you have about you any man whom you can trust, as I conclude you probably have, and would let him drive the cows it would be the best plan, but if you are not able to do this I could probably find out the man who brought my cows from Barmpton 


\section{FIFTY YEARS OF A SHOWMAN'S LIFE}

last year and I would send him down to you. They ought not to go more than nine miles a day, so that I suppose it will take 16 days at least to get them home, as one or two days rest must be allowed. They must keep the North Road to Bawtrey and there ask the way, which is along the Gainsborough Road; but if you will let me know when they are to get there I will have a man and myself also to meet them.

"Believe me, my dear sir,

"Yours most truly,

"Althorp."

A very distinctive personality known in every horse-ring in the kingdom was Henry Fownes Luttrell, of Badgworth Court, in the county of Somerset-or "the Colonel," as he was universally designated, as if there were but one colonel in the world. What he didn't know about horses was, by common agreement, not worth knowing. $\mathrm{He}$ had a reputation in this respect not only throughout the Western Counties, but wherever horse experts were gathered together, which is equivalent to saying that he was known in many companies of Englishmen. There was hardly a single Society offering prizes for horses, from one end of the kingdom to the other, for whom, at some time or another, he had not judged, and, as the embodiment of all wisdom upon equine matters, he naturally became, and remained for many yearsin fact, until ill-health compelled his resignationthe Bath and West Society's senior horse steward; hence I had every opportunity of seeing a good deal of him. It did not take anyone long to 194 
discover that a knowledge of horseflesh was by no means his only claim to distinction, for, in a dozen different ways, he was one quite out of the ordinary ruck. To start with, he always said what he meant, and meant what he said, whether you liked it or not; a by no means common quality nowadays. He had no "pious opinions" simply kept on hand, in order to be trotted out at politic moments, when they were not likely to be acted upon.

Stevenson once said that "To know what you. prefer, instead of humbly saying 'Amen' to what the world tells you you ought to prefer, is to have kept your soul alive." If, as I believe, this embodies a good solid truth, the colonel's soul never lacked vitality whilst joined to his body. He was a most self-contained man, in the sense that he had within himself the main ingredients which made up his pleasure in life, for his habits and tastes were simple to a degree. An intimate friend of his used to say, "Give Hal Luttrell a wisp of straw and a pipe, and he'll be happy anywhere." He was an adept at taking life's cares lightly, never going forth to meet trouble halfway, and his cheery philosophy stood himself and others in good stead. If I confided to him the fear of some impending show yard contretemps, he would calmly administer the following sedative between the whiffs from a briar-wood, which, in his case, was almost a necessary adjunct to all conversation: "It's no use to worry about it. If your catastrophe doesn't come off, you'll have all your trouble for nothing. If it does, there'll be lots of other people to worry about it, 


\section{FIFTY YEARS OF A SHOWMAN'S LIFE}

and they can do that just as well as you. No use having half a dozen fellows on to a job that can be done just as well by one." He had a wonderful memory, not merely for incidents but for facts and figures, as anyone who ever heard him run off horseflesh pedigrees would admit.

Like many others, whose memory stands them in good stead, he had no liking for written memoranda, and, usually regarded official papers either as mere superfluities or simply designed for harassing purposes. His epistolary style was of the very briefest, and, in all my secretarial experience, I have never corresponded with anyone who could pack so much meaning in so few words as he could. He served in the Crimea, and once told me that the best thing that ever happened to him there was the great storm at Balaclava, which, as may be remembered, wrought fearful havoc both on land and sea. He explained the matter as follows: "We were encamped upon the heights, and, while we suffered considerable inconvenience from the effects of the storm, the wind did us one good turn, for it blew clean away the whole of the regimental books, papers and accounts, which had been nothing but a nuisance to us from the time we landed. For years afterwards, when a document was wanted, which couldn't be found, its absence was always accounted for in one way-it was blown away at Balaclava. As it was too much trouble to the War Office to prove the contrary, we heard no more about it, and it's astonishing what a lot of fooling about it saved us." He concluded with a pious ejaculation 


\section{AN UNBENDING TORY}

indicative of his deep indebtedness to Providence for this inestimable blessing.

His philosophy might be summed up in "Put your trust in Providence, and keep your powder dry," and, having acted upon that, he let the world "gang its ain gait." His perfect contentment with most things as he found them, naturally engendered an unbending Toryism in all mundane affairs; hence ardent reformers of show matters had to bide their time, so far as the colonel was concerned, for he was too formidable an opponent, and carried too much weight with the Council, to give an opposition much chance. His sportsmanlike qualities were developed at an early age, for he was captain of the boats when at Eton, and, by a curious coincidence, one of the same name immediately followed him in the position, viz., his cousin, the late Mr. G. F. Luttrell, of Dunster Castle. The colonel was a wondrous teller of afterdinner stories, having not only a most marvellous assortment, but a way of retailing them which was absolutely irresistible. Although he has been dead more than twenty years, there is a frequent echo of his presence at the Mess, of which for long he was President, for his stories still "go marching on," imparted to new-comers by sons who heard them from their fathers, who had them direct from the lips of the colonel himself. But there was something beneath all this independence of thought and action, which, more than mere popular qualities, accounted for the weight his opinion carried, and the influence he exercised. He was sought for the sake of his companionship, but he held his own with all sorts and conditions of men 


\section{FIFTY YEARS OF A SHOWMAN'S LIFE}

by virtue of something beyond this - a penetrating shrewdness which saw deep into things, and an honesty of judgment which could not but inspire confidence. Any time-serving, beating-about-thebush methods were utterly foreign to his nature, for when he had made up his mind he went straight to the point, and dealt with it in language as free from ambiguity as it was possible to conceive. No one could quicker prick a bubble or unmask a sham, as many a backslider has discovered when the colonel sat in judgment, and anyone who thought he could go slantindicularly in his presence was speedily undeceived. But those who steered a straight course and "played the game" could not desire a better champion, and every show yard official, who worked on these lines, knew that he could count upon all the support the colonel could give him.

I very well remember, as a child, the arrival of the news of the battle of Balaclava, and how thrilled we all were at that splendid piece of heroism, the Charge of the Light Brigade. So it will always be a pleasure to me to remember that I had the privilege of frequent communication with one who was an active participator in that never-to-be-forgotten episode, in the person of the late Lord Tredegar. He was a great friend to agriculture, and especially to the exhibition system, so much so that he organized and carried on for many years, at his own expense, an annual show on his own property, for the benefit of his tenants especially, and which cost him not less than $£ 500$ a year. He was much interested in the Bath and West Society, and twice served the 


\section{LORD TREDEGAR}

office of president. He had admirable business qualities, and was an ideal chairman, for he was a master of terse expression, and never used two words where one would do. $\mathrm{He}$ was one of the most polished, the most modest, and the bestgroomed men I ever met. He had just that gentle courtesy which put every one in his company at ease, while, as all South Wales could testify, his generosity was unbounded. On one occasion I spent some time with him in a carriage under rather exceptional circumstances. It was when the show was held at Newport (Mon.), during the presidency of the present King, then Prince of Wales. As we were anxious that there should be no hitch when his Royal Highness visited the show, we had, a few days before the show opened, a carriage rehearsal. In the first carriage sat his lordship, who, as Lord-Lieutenant of the County, would have to share the vehicle with the Prince, and, in lieu of anyone better, I had to impersonate his Royal Highness. The stewards, entering into the humour of the occasion, were in waiting at every department where we made a call, and received me with the most profound obeisances, whilst I, in return, graciously unbent in the manner of royalty. But it seemed to be such a remarkable linking up of the present with the past that, after all these years, I should be playing a game of make-believe with a man, who, as a member of an immortal band, was one of the heroes of my childhood. Verily, it is the unexpected that always happens!

I have mentioned his lordship's power of verbal compression, and I remember one particular 


\section{FIF'TY YEARS OF A SHOWMAN'S LIFE}

instance of this. At a municipal banquet given to the Society at Cardiff, one of the early toasts was "The Houses of Parliament," to which a Member of the Commons replied. When he sat down, there was a loud call for Lord Tredegar to speak for the Upper House. His lordship was, however, nominated for another toast later on, and as, although he was an excellent speaker, he always effaced himself when he could, he did not want to hold forth twice. But, as the call for him was persistent, he rose, and, after the warmth of his reception had subsided, and there was an expectant silence, he simply gave utterance to the one word "Resurgam" and sat down, amid a roar of laughter. When he rose again, later on, he made amends for his previous reticence by the appositeness and humour of his remarks. I remember one instance in his speech of the latter quality. With delightful seriousness, he recalled how, in the course of his early classical studies, he read of a battle in Greek history in which the combatants were so absorbed in pursuing the fray that even an earthquake in their midst, happening at the same time, was quite unnoticed, and did not stop the fighting for a single instant. He said he had found its parallel in the Bath and West show yard that day, on which, as they all knew, the great sporting event of the year, the Derby, was run. Yet no steward took the slightest cognizance of this ; every one was at his post, and so wrapt up in his duties that, so far as the stewards were concerned, the greatest race in the world might never have come into existence. In view of the sporting instincts of all Englishmen, he could 


\section{THE BALACLAVA CHARGE}

hardly conceive a finer example of devotion to duty. The only exception to the self-denying ordinance this represented was to be found in the Society's secretary, he being the one official who manifested the slightest interest in the matter, or who took the trouble to ascertain the name of the winner, but his well-known sporting proclivities fully accounted for this. This was a good-natured thrust at my indifference to racing matters, as shown by my always opposing altering the dates of the show, in order to avoid the Derby Day. His lordship was a real sportsman in the best sense of the term.

There have been so many different versions of the Balaclava Charge that the following account of it given by his lordship, who led a squadron in the charge, and was one of the only three officers in his regiment who came out of it unscathed, seems worth reproducing. In a letter, written very shortly after he had taken part in the charge, he says :

"We, the Light Brigade, were drawn up at the other end of the valley, facing their position, distant about three-quarters of a mile, waiting, I had imagined, for infantry to come to our support, when suddenly an aide-de-camp (poor Nolan) galloped up with an order, 'The Light Brigade will attack; the 17th and 13th will advance, supported by the 8th and 11th and 4th.' Knowing the strength of their position and our want of proper support, I felt it was a critical moment, but, grasping our horses by the head, away we went. We had not gone many yards before we were under fire of the first heavy battery 


\section{FIFTY YEARS OF A SHOWMAN'S LIFE}

on our left, the first shot of which killed poor Nolan, a splinter going right through his heart, and his horse carried him back to us. . . On we went, the pace increasing, amidst the thickest shower of shell, shot, grape, canister, and minie, from front and flanks-horses and men dropping by scores every yard. The whistling and cracking of shells was beyond all description. Under this we went for three-quarters of a mile, the enemy's guns firing in front of us till we were within a yard and a half of them. Just as I came close to one it went off, and, naturally, round went my horse. I turned him round and put him at it again and got through, the cavalry retreating the other side. Not more than a dozen of the 17th and the same number of the 13th were to be seen, so we turned to come back, knowing we could not hold the guns we had taken. The 8th, 4th, and 11th followed us in, and suffered nearly as much as ourselves. We saw the enemy between us and home, and at them we went. I cut down one fellow as he ran one of my fellows through with a lance, and, digging my spurs in my horse's sides, he went at it as he has often gone at the big fences in Monmouthshire. I got through them with only a few lance pokes, which I managed to parry, but the number of men had diminished. We had to retire through a shower of Minie bullets, and we re-formed in rear of the Heavy Brigade. I numbered off 32 men. We went into action 145 in the morning. The 13th lost more, and the other three about half their number. Our mess was sadly shortened-of seven only two remained sound, one was killed, the others wounded. The 


\section{JONATHAN GRAY}

worst of the whole thing was that the enemy still retained possession of the ground, and they are now forming entrenchments. Much mistaken if they think we are going to attack them."

From the time of its inception, the Bath and West Society has been exceptionally fortunate in its voluntary workers. The vitality which has sustained it during its long life, and such success as it has achieved in the course marked out for it, must be set down mainly to these shapers and moulders of its policy who created and perpetuated its standard of work and responsibility. Instances among these of exceptional devotion to the Society's interests serve to bring forcibly home, from time to time, the strength of its hold upon those most capable of serving it, and the disinterested zeal and enthusiasm it is able to evoke. Whilst the examples I have given may serve to illustrate this, I have left unnamed scores of others equally entitled to remembrance, and to whose memories I would gladly pay tribute did space permit. I will, however, content myself with briefly recalling three more notable personalities. The first, in seniority, was Jonathan Gray, the living embodiment of the Society's best traditions, the repository of all knowledge concerning it, and the ungrudging giver of all that continuous work for it represented. He may be said to have lived for the Society, which was the one hobby of his life, at which he was always working. He was the self-constituted watch-dog over everything and everybody connected with it. When I was debating in my mind whether or not I should 


\section{FIFTY YEARS OF A SHOWMAN'S LIFE}

offer myself for the vacant office of secretary, a personal friend, who knew the Society well, solemnly abjured me not to think of it, for, says he, "Jonathan Gray will worry you into your grave." Said I, "I have never yet seen the man who could bring me to that pass, and I don't expect to do so on this earth, so, if that's the only obstacle, I shall chance it." Which I did, and have never regretted it; besides which, at the moment of writing, I am alive still. Jonathan departed years ago, much to my sincere sorrow, for he was not only one of the best friends the Society ever had, but one to whom I became personally attached by ties not merely of regard but affection.

Then there was the Hon. and Rev. J. Y. Boscawen, the most kindly and sympathetic of mortals, with a knowledge of floriculture, utilized for the benefit of the Society, as varied as it was unique. Last, but not least of the three, was Captain John Best, the typical Englishman, the "strong" man, in that sense of the term which means force of character, power of grasp, and a capacity to sum up the possibilities of a situation in double-quick time and to act as promptly. In those emergencies, when delays are dangerous, and some one has to act without waiting for orders -as will sometimes happen even in the bestregulated societies-I never feared, when once I had his backing, to take my courage in both hands, in full confidence that, when the question came up to Council for revision, he would see the matter through with an outspoken fearlessness which would bear down all opposition. He was a 


\section{PAST-MASTERS OF CHAIRMANSHIP}

valuable asset on deputations to local bodies, for his fine presence and cheerful bonhomie inspired confidence and were passports to a sympathetic hearing. -

Here I must stay my hand, tempting as it is to call back to recollection those whose memories are so full of pleasant associations. Alas, all those I have named are dead and gone. But I can truly say with Bolingbroke:

\section{"I count myself in nothing else so happy,} As in a soul remembering my good friends."

It does not fall to the lot of every official to be subject to the rule of so many chairmen distinguished in various ranks of life as it has been my privilege to serve under, for the Bath and West Society has been fortunate in inducing many holders of high office in the service of the State to spare time for the discharge of the duties of the presidency. They have included leaders in both Houses of Parliament, Cabinet Ministers, and Colonial Governors, and one of the most eminent of the long line of House of Commons Speakers. I have happy memories of all of them and of their many kindly acts, while not a few have been such past-masters of chairmanship that it has been an education in the art of conducting public business to observe their methods. 


\section{CHAPTER XIX}

Royalty in the Show Yard-The Late King Edward-Some Equine Irreconcilables-The Area of Responsibility-The Present King -An Accomplished Pony and an Enterprising Waiter.

THE Society's Annual Show has been honoured by the presence of Royalty 1 on several occasions, and for many years past there has been a goodly display of Royal stock in the show yard. The late King Edward VII. identified himself in the most practical way with the greatest of our national industries, and lost no opportunity of testifying his interest in it. The high standard he set himself in everything he was responsible for was illustrated by the quality of the stock - of which he was not only the exhibitor, but the breeder also-shown by him at the Bath and West meetings and elsewhere. He honoured the Society by becoming its patron when Prince of Wales and by renewing the association on ascending the throne.

Long before I ever dreamt of seeing Royalty in a show yard at close quarters, the late King's form and features - at that time in all the freshness of youth-were very familiar to me, for, when he was an undergraduate at Christ Church, Oxford, I was making a not-too-willing acquaintance with certain Latin and Greek authors at 206 


\section{"AN HONEST GENTLEMAN"}

the school attached to the same foundation. As I crossed Tom Quad, on my way to morning school, I used to have the privilege of "capping" his Royal Highness as he was returning from early chapel, and I remember the gracious and kindly response which he always accorded to the salutation of even a small boy like myself. Then, as Prince, as afterwards as King, no courtesy went unacknowledged, and Oxonians had several opportunities of appreciating the growth and development of those popular qualities which endeared King Edward VII. to the hearts of his people. I have a story in my mind which, although it has nothing to do with agricultural societies, I cannot resist quoting, as it so well illustrates the kindly courtesy of which I have been speaking.

His Royal Highness, with one of his equerries, was one afternoon out for a country walk, in the neighbourhood of Bullingdon, about three miles out of Oxford, when they were overtaken by a downpour of rain. Being unprovided with umbrellas, they sought the shelter of a cottage, where they passed some time in friendly chat with an old dame, who little recked of the rank of her visitor. The rain abating not, the possibility of obtaining the loan of an umbrella was mooted. The dame hesitated a little at first, because, as she put it, "I don't know who you are or where you come from, though I think you be college gents." However, she produced a very fine and large gingham, of ancient type, and handed it to the Prince with the words: "You look like an honest gentleman, and I hope you 


\section{FIFTY YEARS OF A SHOWMAN'S LIFE}

are, so do 'ee bring it back, for it's the only one I've got." A promise was given that it should, without fail, be once more in her keeping on the following day. The old dame's astonishment may be conceived when a footman called upon her on the morrow with the umbrella, together with a guinea, which she was asked to accept with his thanks from the Prince of Wales. The compliment to the Prince implied in the dame's remark as to the honesty of his looks was much appreciated when the story, having gone the round of the village, reached Oxford.

Any show yard officials upon whom devolved the duty of attending upon the late King when he honoured a show with his presence would be able to testify, to his invariable consideration for those upon whom any responsibility rested, to the tact and courtesy which never failed him, and to his kindly desire to fulfil to the full all that was expected of him.

The first occasion in my own time upon which his late Majesty, then Prince of Wales, visited a Bath and West show yard was at Dorchester in 1887. After alighting at the Council pavilion, where he was received by the president and officials, it was his pleasure to visit the various departments of the show on foot. The horse ring to which he first bent his steps, was some distance from the pavilion, and the road to it was occupied by a great concourse of people, many of whom had taken their stand on the top and sides of a slope bordering a portion of the route. Arrangements to clear a passage had to be made at short notice, but, as there were plenty 


\section{THE DISIN'EGRA'IION OF A PROCESSION}

of police and ropes, those of us who were in attendance upon the Prince hoped for the best as we viewed the crowd ahead of us. The Prince, with his suite, was escorted by the president (Lord Ilchester) and a bevy of vice-presidents and officials. All went fairly well, with just enough room to get through the mass of people, till we reached the slope, when, to my horror, I saw the front rank of spectators, yielding to the pressure of those behind, gradually giving way as we approached. As the little procession advanced the interest and enthusiasm became intensified, and the desire of everybody to have as near a view of Royalty as possible overcame every other consideration. Easy indeed was the descent when once the hindmost on the embankment had supplied the impetus, and all at once it was seen that a boisterous, good-tempered crowd, without any power to stay its own force, had overwhelmed police and ropes, and were surging around us. The little procession was, soon resolved into its component parts, and those constituting it, with one exception, were struggling for all they were worth to keep their legs and to save their frock coats and top hats from annihilation.

Any efforts on our part to maintain a passage would have been as futile as Mrs. Partington's endeavours to stem the tide with her mop, so we could only resign ourselves to our fate, and, tossed about like rudderless ships in a storm, go whither the winds and waves, otherwise the populace, elected to take us. To add to our physical inconvenience there was the appalling 


\section{FIF'I'Y YEARS OF A SHOWMAN'S LIFE}

thought of what was happening to the HeirApparent. At such times minutes seem to posșess the longevity of hours, but even the worst of nightmares lasts but a brief spell, and in detachments, somewhat dishevelled, but otherwise no worse for what we had gone through, we reached the horse ring, where, to our intense relief, we found his Royal Highness safe and sound, with nothing in his glance to indicate that he had experienced anything unusual. The people, with whatever lack of consideration they might have had for the rest of the party, whom they probably regarded as of no particular account, did not permit their exuberant demonstration of loyalty to interfere with the progress of their Prince. They somehow kept a passage for him, so that he passed through their midst without let or hindrance, and with no fear except perhaps that arising from the thought that the crowd's selfimposed barrier might not be strong enough to withstand the stress and strain to which it was subjected.

Our apprehensions were soon further relieved by the Prince himself, for he turned to Lord Allington with a cheery smile and the remark, "How well the people behaved!" And thus, as with the wave of a Prospero's wand, were our fears dissipated, and the capacity of Royalty for putting all around at their ease was brought home to us.

His late Majesty, together with Queen Alexandra, then Princess of Wales, next visited the show in 1896, when it was held at St. Albans. It was, happily, a day of brilliant sunshine, and 


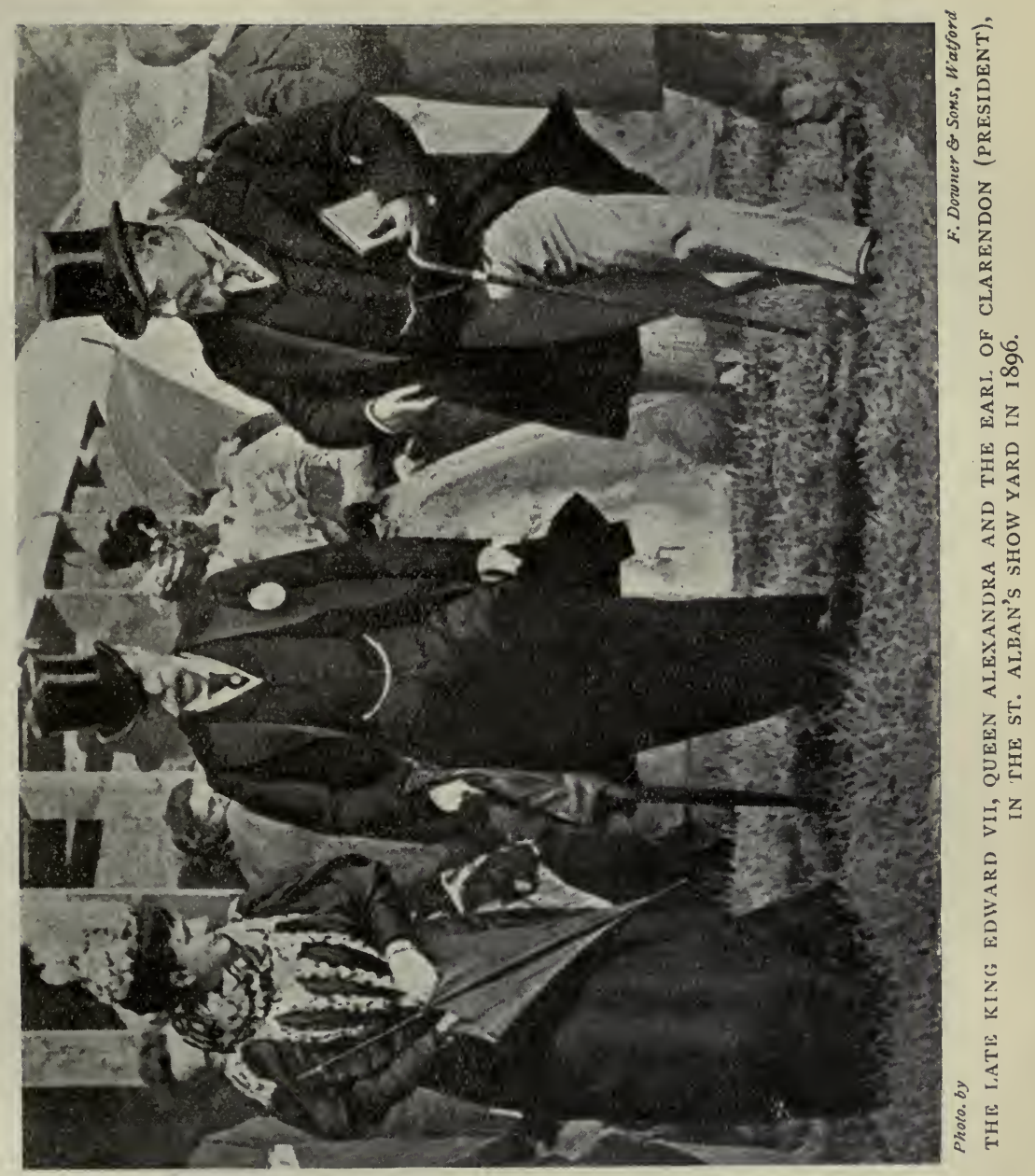





\section{KINDLY THOUGHTFULNESS}

this gave opportunity for one of those acts of gracious courtesy of which the late King's life was so full. As I walked by his side, hat in hand, we had not gone many paces when he said to me, "Please put on your hat; it is not safe to go without it on such a sunshiny day as this." Later on in the day, when I was in attendance upon the then Princess of Wales, the latter, with kindly thoughtfulness, also rendered me.her debtor by preferring a similar request.

The St. Albans show yard was a very long one, and the various departments were somewhat far apart. Hence it was deemed desirable for Royalty to traverse most of the ground in carriages, an arrangement which, after the Dorchester experience, was calculated to lessen secretarial anxieties. On this occasion there was an unusual gathering of Royalties, for with the Prince and Princess of Wales were Princess Victoria, Princess Maud, and Prince Charles of Denmark.

Their Royal Highnesses, who were staying at Hatfield, were accompanied by the then Premier (the Marquis of Salisbury) and the Marchioness, the Secretary of State for War (the Marquis of Lansdowne), the President of the Board of Agriculture (Mr. Walter Long), the President of the Local Government Board (Mr. Chaplin), and other notable personages. There was, consequently, a fairly long string of carriages to be manœuvred amid the crowds of a show yard as they conveyed these distinguished visitors to the several departments of the show. It was considered desirable that the President (Lord Clarendon), with the Secretary at his elbow, should receive the Royal 


\section{FIFTY YEARS OF A SHOWMAN'S LIFE}

party on their arrival at each department in order that his lordship might make the necessary presentations of the various stewards in charge, and we could not very well leave any of the departments until we had bowed the Royalties back to their carriages. This led to what has always appeared to me the funniest incident in which I ever bore part in connection with shows. The only way, as it appeared to us, to carry out this programme was for the carriages to traverse the main thoroughfares at not too hurried a pace, whilst the president and myself took to our heels and made for our objectives by other lines of route not too effectually barred by the crowds occupying them. Thus we had sometimes to make wide circuits and detours, and at others to avail ourselves of short cuts. This latter course necessitated our dodging in and out of implement sheds, amid reapers, binders, haytedders, and such like fearsome impediments to a hurried progress. Once we had to leap and bound amid the pegs and guy-ropes of some marquees, which all but bowled me over, and must have conveyed the impression to an onlooker that we had entered ourselves for an obstacle race. Happily, however, everybody was too much intent upon observing the movements of Royalty to give heed to our gyrations, and so we cannot be said to have seriously jeopardized our dignity. Beyond this, the game was well worth the candle, inasmuch as we accomplished our task to our own and everybody else's satisfaction, for, although we sometimes ran it very close, we somehow always managed to arrive 


\section{SOME EQUINE MISCHANCES}

just in time, with scarcely a second to spare, to present ourselves, a panting and perspiring pair, as Royalty descended from the carriages. The successful accomplishment of the feat further testified to our staying powers, and left us no room to doubt, but that we were sound in wind and limb. To myself, the greatest gain of all was that it has furnished me with a reminiscence, which, even after this lapse of time, never fails to call up a smile whenever I think of it; no small benefit when one is inclined to take oneself too seriously.

On that particular day, as it happened, some of the distinguished persons who were in vehicles had no reason to congratulate themselves on being there, for there was a remarkable series of equine mishaps. One vehicle was overturned, another broke down, and the steeds attached to a third could not be induced to start at all. Happily Royalty was exempt from these mischances, and no one suffered anything worse than a shaking. In my mind's eye I shall long see the closing incident of that eventful day. It is an animated picture of a swaying wagonette attached to a couple of apparently fiery, untamed steeds, "kicking up behind and before," with two Cabinet Ministers hanging on to their heads, and the burly figure of the then Premier gripping the sides of the vehicle to save himself from being deposited outside of it. All around are uprising voices beseeching his lordship to descend and run no more risks, and, when at last he responds to these entreaties, I see the steeds, satisfied at having relieved themselves of so precious a consignment, 


\section{FIF'TY YEARS OF A SHOWMAN'S LIFE}

making a sudden bolt for the exit gates in order to catch up the rest of the procession. In justice to all concerned, I ought perhaps to say that the Society was not responsible for either the horses or the vehicles. I was given to understand that the Marchioness was the Master of the Horse in the Hatfield establishments. I have seldom felt happier or more relieved than I did that day when I saw the last carriage load of notabilities safely out of the show yard.

The St. Albans meeting brought me into contact with the late Lord Salisbury, then Prime Minister, but more particularly with his devoted helpmeet, the late Marchioness, whose special mission in life was to save the Marquis from every possible preventable care or anxiety outside the region of Parliament. At Hatfield itself, she not only reigned but governed, so far as its internal economy was concerned, and was also a factor to be reckoned with in respect to not a few matters outside of it. This accounted for her visiting me in the show yard a few days before the show in order to discuss general arrangements. She opened the ball by making it known to me that she held me responsible for all happenings to the Royal party and suite from the time they left Hatfield for the show yard until on their return they had. re-entered the park gates of the mansion. I lost no time in inducing a different impression by assuring her ladyship, with all the deference at my disposal, that my responsibilities began and ended with the show yard itself, which was as much as I was equal to. As such a limitation of my duties took the Marchioness entirely by 


\section{ROYALTY AND LABOUR}

surprise, I suggested, with a smile that was as "childlike and bland" as that worn by the Heathen Chinee, that no doubt if she approached the Chief Constable of the County he might be able to help her, so far as keeping the line of route outside the show yard was concerned; and I believe that the difficulty was solved in this way. Had it been anybody but a Marchioness I should have concluded that, in the argot of the smoking-room, she was "pulling my leg" when she proposed such an enlargement of my sphere of duties, but, of course, this, as an explanation, is unthinkable in her ladyship's case. It probably was only an astute method of ascertaining to what extent I was prepared to accept responsibility, and, if so, it entirely fulfilled its purpose.

The present King, in the show yards he has visited, has earned the same character for kindly thoughtfulness as his illustrious father so long enjoyed, and the broad-mindedness of his consideration has been shown by actions within my own knowledge. In 1907, when Prince of Wales, he was president of the Bath and West Society, and a few days before he paid his official visit to the show, which was held at Newport (Mon.), I received a request from him that at least one Parliamentary representative of Labour should be included among the, necessarily, select fewfor the apartment was small-who would have seats at his Royal Highness's private luncheon table. Further, having ascertained that most of the Labour representatives of South Wales proposed to be present at the show when he attended it, he at once expressed a hope that they 


\section{FIFTY YEARS OF A SHOWMAN'S LIFE}

would avail themselves of the special train which would convey himself thither. Similar consideration was shown for the crowds which thronged the route to the show yard, for, although the Prince was pressed for time, he waited ten minutes at the railway station for the rain to abate, because, as he said, the people would be disappointed if those in the procession were in closed carriages. A homely note was struck when his Royal Highness, in the working dairy in the show yard, mentioned the particular breed of cattle supplying the milk on which all his children were brought up, and added, referring to his offspring, "A healthier lot you wouldn't find." I purposely forbear stating the breed the Prince referred to, as it would only land me in an interminable correspondence, with a view to showing that I must have misunderstood the Prince, as no Royal Family could possibly be successfully reared except on the milk of the particular breed affected by the writers. The battle of the breeds, from a dairying point of view, has by no means exhausted itself.

Animals do not always enter into the spirit of the occasion by laying themselves out to afford entertainment when Royalty or other distinguished visitors honour show yards with their presence. But there was a remarkable instance at this particular show of an earnest desire on the part of a pony to make manifest his appreciation of the company he appeared before and to bring himself under public notice. The equine prizewinners were, as usual, paraded before his Royal Highness, who witnessed the display from the 


\section{A VOLATILE PONY}

grand stand, and all this particular pony had to do was, led by his groom, quietly to pass as one of a long procession before the Royal party. This, however, was not at all in accordance with the fitness of things, as visualized by a pony of soaring ambitions, when there was so good an opportunity of distinguishing oneself. With the secret of his intentions locked within his own breast, he approached the Prince with all the calmness and decorum of a funeral hack. But when arrived opposite Royalty it made a dead halt, and, raising itself on its hind legs, gracefully saluted with its fore-feet -at least that appeared to be the purport of the movement. Not content with this, he then proceeded to exhibit his agility and high animal spirits by a series of Jim Crow movements, followed by a selection of curvetings, pirouettings, friskings, gambols, and every other evolution of which the most kittenish of ponies could be capable, the procession being meanwhile delayed to the disgust of the other animals and their leaders, who were kept waiting without any such opportunity of distinguishing themselves. At last the volatile one, having exhausted his many accomplishments, consented to move on, which he did apparently well-pleased with himself, amid the hearty laughter of the Prince and the approving plaudits of the spectators. I am no interpreter of animal physiognomy, but, if ever a pony had a beaming smile, I should say it was worn by that particular quadruped as he wended his way back to his stall.

It is curious how large the trivialities of life loom in memory and how enduring they are. 217 


\section{FIFTY YEARS OF A SHOWMAN'S LIFE}

Ask anyone who was present at the show that day what they remember about it, and you will get as your answer, "Wasn't that performing pony a joke!" They may talk afterwards, if encouraged, of the grand exhibition it was of live-stock, machinery, etc., but it will be found that the scene in the arena with the pony disporting himself will take first place. It is very much like the effect one experiences when on the summit of St. Paul's or other height well above the "madding crowd." Notwithstanding the unceasing whirr and roar created by acres of machinery in innumerable factories, printing offices, etc., and the never-ending hum of a mighty traffic; there stands out, more clear and distinct than all the rest, the barking of a dog in a bystreet, or the squalling of a child in one of the alleys.

Other Royal visits include one in 1894, when the show was held at Guildford, and was honoured by the presence of the Duke and late Duchess of Connaught, who maintained to the full that character for kindly geniality shared by all the members of our Royal House. A comic incident in connection with the visit represents another of those trivialities that dwell in memory. Refreshments for the Royal party were provided in the Council pavilion, cherries being among the fruits set before and enjoyed by their Royal Highnesses. As soon as the latter had departed, one of the waiters, with a quick appreciation of possibilities, caught up all the cherry stones which Royalty had omitted to swallow, cleaned and polished them, and then, having mounted 


\section{A CHERRY-STONE SOUVENIR}

them as scarf-pins, vended them at eighteenpence apiece as souvenirs of the occasion; at which price they went like hot cakes. Who after this could doubt the loyalty of the show yard Englishman, or the enterprise and ingenuity of that Guildford Ganymede! I have often wondered what was his after-career, for the resourcefulness which suggested such an adaptation of means to an end gave promise of a great future. In these latter days, when we are finding a use for all manner of, hitherto, waste products, his fertile brain would be an invaluable asset. With such a gift for making the most of anything, he might be expected to get blood out of a stone, or extract sunbeams from cucumbers. 


\section{CHAPTER XX}

An Archdeacon on Cheese-And on the Trinity-George Gibbons-

"Where the best Princesses come from "-The Song of the Cheese.

DEW people knew the constituents of a good 4 Cheddar cheese better than that embodiment of the Church Militant, the Rector of East Brent, the late Archdeacon Denison, so some remarks of his, in a letter in my possession, dated May 20th, 1887, and addressed to the late Mr. George Gibbons, a kindred soul in all pertaining to cheese, seem worth quoting. In regretting his inability to attend a meeting with reference to cheese-making, he says : "Many in their 82 nd year are much more active than I am, free from stiffness of hip-joint, knee and wrist, though, perhaps, it is not many who are in better health generally. I was quite sure when I went to bed yesterday that it would be foolish to move to-day. I suppose that though there is a large quantity of first-rate Cheddar, such as we generally rejoiced in 20 years ago, still made among us, and made nowhere else, there is a larger quantity of second-rate cheese made than there used to be, and this is necessarily damaging to the character of the first quality. Now, if we are to see Cheddar's pre-eminence restored, we must look after being, as we used to be, pre-eminent in making. 


\section{AN ARCHDEACON ON CHEESE}

"Then, for remunerative price, I know of no remedy for low price of really good cheese, but the direct sale by maker to consumer, and I have done, and am doing, what I can in my small way to establish such direct sale between my more intimate Cheddar-making friends and large centres of population. I have succeeded in good measure between Liverpool and Cambridge, etc., etc., and these parts-and this is about all I can do. I wish it might be found possible to make this a general plan.

"Last Saturday I ate at a friend's house near here, I think the finest 4-year-old Cheddar I ever tasted, dark, but perfectly sound and sweet. I should like to see American, Canadian, or 'the World ' Cheddar four years' old side by side with it. I am told it was made in E. Brent, but have not yet heard by whom. Last summer I bought from a dealer a sample of Canadian, which he praised much. I did not think much of it at the time. When it had been here three weeks I declined to try it again-the surroundings were not good."

I have early recollections of the archdeacon, for when I was a boy he was greatly exercised in his mind at what he regarded as the heterodoxy of the Broad Church. He was one of the chief instigators and organizers of the crusade at Oxford against the Essayists and Reviewists, whom it was sought to bar from entry to the University pulpit or from enjoying professorial emoluments. The archdeacon was largely instrumental in securing the defeat of Max Müller, when he was a candidate for the professorship of 


\section{FIF'TY YEARS OF A SHOWMAN'S LIFE}

Sanskrit, and of the proposal to increase Jowett's stipend as professor of Greek; the basis of objection to both individuals being their supposed unorthodoxy. As my father shared the archdeacon's views, he lent him his aid in the practical working of the machinery of opposition. So I heard a good deal about the archdeacon and his doings at this time.

In after years his individuality and the tenacity with which he held the faith, as he regarded it, and his inflexible determination that others should hold it, were brought forcibly home to me. It so happened that, at the Sunday service in the yard during my first Bath and West Show, held at Bridgwater in 1883, the archdeacon was the preacher in lieu of the Bishop of the Diocese, who was unable to officiate. To the surprise of all present, the archdeacon devoted the whole of his discourse to an elaborate and learned exposition of the doctrine of the Trinity, with particulars of the direful consequences of not accepting all that it represented; in fact, it was just such a sermon as one would expect to hear preached to the theological experts at St. Mary's, Oxford, by Dr. Pusey or some such master of doctrinal intricacies. But it was certainly not what one would have expected to hear addressed to a congregation mainly composed of herdsmen, shepherds, and such like simple-minded folk, for whom the service was specially intended. I was puzzled to account for it until, having confided in the Society's chaplain - that most delightful of clerics and horticulturists, the late Hon. and Rev. J. T. Boscawen-he furnished the explanation 


\section{ATTEMPTED RESCUE OF A UNITARIAN}

from his own knowledge. It appeared that just previous to the service the archdeacon lunched with the Mayor of Bridgwater, who was to accompany his reverence to the service. Before they reached the yard the guest discovered that his entertainer was a Unitarian, and at once the archdeacon had the conviction strong upon him that it was his bounden duty to show his Worship the error of his ways and thereby save his soul. So, abandoning all thought of the majoritywho as far as he knew might be perfectly sound upon so controversial a subject-he devoted all his efforts to rescuing the Mayoral minority of one. He had, as he believed, a special mission thrust upon him, and, this being so, he was not the man to let anything stand in the way of his fulfilling it. Any one who knew the archdeacon would have no difficulty in understanding how this thought would grip him or would doubt his absolute sincerity in this or any other matter which had possession of him. As I ascertained afterwards, however, even the archdeacon's powerful arguments were insufficient to induce the lost sheep to enter the church-fold. I never missed the show yard service during all my 35 years of office, and this was the only address that had no reference to the special circumstances of show week.

I have many pleasant recollections of show yard sermons and those who preached them, and can often in imagination hear the resonant voice of the late Dr. Thorold, Bishop of Winchester, who arrested the attention of everybody at the onset when, with impressive emphasis, he gave out 


\section{FIFT'Y YEARS OF A SHOWMAN'S LIFE}

the text, "Does God take care for Oxen?" and after an effective pause supplied the answer with startling and commanding emphasis, "Of course, He does!" And then followed a discourse, which, by its force and directness and its understanding of the rural temperament, came home at once to the minds of the listening country-folk.

Any record, however limited, of services rendered to the Society and to cheese-making, would be indeed incomplete if it did not include a mention of that striking personality, the late George Gibbons, of Tunley, to whom the archdeacon's letter was addressed, and whose reputation extended far beyond his native county of Somerset. By his force of character, strength of purpose, abounding energy and unique experience, he was enabled during a long and active life to render inestimable service to agriculture, and especially to the dairy side of it. By those engaged in the latter industry, he was regarded as the very fountain of knowledge, as the very chief of experts.

$\mathrm{He}$ had a distinguished agricultural career previous to actively associating himself with the Bath and West Society, having been awarded, in 1875 , the first prize of $£ 50$, offered by the Royal Agricultural Society for the best-managed dairy farm in the county of Somerset, and having gained prizes for Cheddar cheese at all the leading shows in this country and abroad, whilst he held many positions of trust in the Agricultural world. Space will not allow of my doing more than recalling some of his personal characteristics, as they presented themselves to me during my association with him in the Society's work. He 


\section{GEORGE GIBBONS}

was elected on its governing body in 1883, and he was not long in making his influence felt, especially in connection with dairying, being a strong supporter of the recommendations already referred to of the special committee, of which he was a member. These resulted in the Society taking a much more active part than hitherto in the promotion of the industry. In point of fact, the Society was enabled to embark upon its new departures in this direction with the cheering confidence that it had in Mr. Gibbons one who had both the knowledge of what was required, and the ability and the willingness to bring it to bear. He threw himself heart and soul into the work, and to his untiring energy was greatly due that success in the movement for dairy education, which it never lacked from start to finish. I doubt if he were ever happier than when he was on those many expeditions, which I shared with him, having for their object the teaching of the country-side the advantage of proved methods over the old rule of thumb. I can testify to his remarkable endurance on those occasions, for he never seemed to tire, however tedious the journey or however arduous the duties to be fulfilled in addition. I have often envied him his alertness at the end of a long day, sometimes running well into the night, spent by both of us in organization work and in travelling to and from out-of-the-way places.

He was a great believer in sulphate of ammonia, not only as a fertilizer, but especially as a personal pick-me-up. He carried a supply of it loose in his waistcoat pocket, and, when feeling tired and in want of a reviver, he took a 


\section{FIF'TY YEARS OF A SHOWMAN'S LIFE}

pinch as though it were snuff, and always declared it did him " a power of good."

He was a ready and fluent speaker-preferring to trust to his voice, which served him well, rather than to his pen, for the promotion of any cause he had at heart. Nevertheless, he contributed several good practical articles on his favourite subject to the transactions of various Societies. He was constantly being applied to by landowners and various public bodies to recommend them dairy assistants, for no one knew better than he where to put his hand upon what was warited in this connection, and he had the honour, which he greatly esteemed, of finding dairymaids for both the late Queen Victoria and King Edward VII. for their Windsor Dairy. He was in universal demand as a judge of anything and everything pertaining to dairying. Implements also came within his adjudicatory sphere, whilst he was one of the judges of farms for the Royal. Agricultural Society in 1880. He was Napoleonic in his ideas, and it was no easy task to convince him -in fact, you never did convince him-that there could ever be an insuperable obstacle to the realization of anything upon which he was bent. His natural hopefulness, which represented an ever-trustful belief in possibilities - otherwise uncertainties-rendered it impossible for him to take failure into his reckoning, whilst it was equally difficult for him to conceive of any financial limitations when his heart was set upon what his brain had conceived. His sanguine temperament chafed under official restraints, so. we often agreed to differ, but it was 


\section{THE "ROYAL " SHOW IN 1840}

with regard to methods rather than principles, and it never interfered with the continuity of our friendship. "Difficulties," he used to say, "were made to be overcome," and, if it were urged that, something he had in his mind was "impossible," he was apt to think that every argument was met, when he remarked that he had no such word as "impossible" in his dictionary. Although he did not compass all his ends, he often succeeded where another, with less confidence, would have failed. He worked upon broad lines, leaving details to others, and he preferred to rely upon his own resourcefulness - which rarely failed himfor help at a pinch rather than upon anticipatory preparation, whilst a state of high pressure seemed rather congenial to him than otherwise.

He made himself at home wherever he went, and his natural, unaffected ease of manner helped him to hold his own in whatever company he found himself. He was a good raconteur with a most retentive memory, which enabled him to hark back upon the past to the interest of his listeners. He was fond of recalling his visit as a boy to the Royal Agricultural Society's fourth show at Bristol in 1840, on land, now built over, near the Victoria Rooms, and he would draw instructive comparisons between the nature and dimensions of that exhibition and its successors in after-years. He attended the big dinner held on that occasion in the show yard when 1700 sat down, and there were seventeen toasts - a greater infliction than would be borne patiently nowadays. That he was an adept at promoting friendly discourse was testified to by the cheery conversational 


\section{FIFTY YEARS OF A SHOWMAN'S LIFE}

ripple which ever marked his place at the Council Mess. He could bring his unusually keen powers of observation to bear with all the more effect, because he kept himself so well up-to-date with respect to the movements of his time, especially in connection with everything relating to the country-side.

He had a shrewd and ready wit with which to drive a point home and a special aptitude for the bestowal of a pretty compliment-especially when it found its application in one of the opposite sex whose looks were on a par with the grace of the compliment. The story of how effectively he once brought his special gift to bear in the presence of Royalty has oft been told, but I think it is entitled to mention here, as it is so characteristic an instance of that tactful readiness of reply which so often sprang spontaneously from his lips. At the Bath and West Show at St. Albans in 1896, the Princess of Wales, who was being shown round the Working Dairy by Mr. Gibbons, observed with a smile, "The best butter, you know, comes from Denmark." "Pardon me, your Royal Highness," said the steward, with a twinkle in his eye, "we think the best butter is made in England, but we have to go to Denmark for the best Princesses." The Prince of Wales overhearing this, joined in with: "Ah, now you're buttering her!"

His length of years, and the retention, until within a comparatively short time of his death, at the ripe age of 84 , of his mental and physical powers, go far to prove that hard work is not incompatible with prolonged life, however full 


\section{A WEDDING GIFT TO ROYALTY}

and strenuous that life may be. By the many with whom he was associated in public work, he will long be quoted as an example of how much usefulness a single life can compass and how well a man can serve his day and generation when he gives his mind to it.

A few years previous to his death, the Society, in recognition of the valuable services he had rendered to it and to Agriculture generally, unanimously elected him as a vice-president.

I have testified somewhat fully as to the manner of man George Gibbons was, because he was so much out of the ordinary ruck, and because I doubt if anyone, outside his own family, saw more of him than I did. We travelled many. hundreds of miles in each other's company, with the opportunity this afforded for close intercourse; we stood together on many public platforms, when our joint mission was to enlist recruits for the Dairy Schools; we exchanged many confidences; and it fell to me to help materialize, and put into practice, the developments of his active mind.

On the marriage of the present King, he graciously accepted a wedding-gift from the Society, consisting of a Cheddar cheese made by students at the Society's Cheese School, and which was awarded a first prize at the Society's Gloucester Show; the presentation being made on behalf of the Society by the late Lord Fitzhardinge, the President of that year, 1893.

Here we have another instance of history repeating itself, or very nearly, for I have a copy 


\section{FIFTY YEARS OF A SHOWMAN'S LIFE}

of a song, both words and music, which I once picked up at a second-hand bookseller's. The following appears on the title-page :

Published by Subscription.

New Song.

The Royal Cheese.

Made at West Pennard, Somerset,

(From the milk of Seven Hundred and

Fifty Cows).

Intended as a Present to

Her Majesty Queen Victoria, respectfully inscribed to

The Farmers of the West of England.

The Music by

T. Williams.

Ent. Sta. Hall. (Pr. 2/. To Subscribers $1 / 6$ ).

Author of "Not a Drum was heard," "Old England shall weather the storm," \&c.

LONDON : 2, Strand, Trafalgar Square.

Surmounting this inscription is a copper-plate engraving. In the background is represented the stern of an old three-decker, on which is inscribed, as its name, "Victoria," with the Union Jack floating proudly above it. In the foreground are three British sailors, the foremost of whom bears a big round box, with "sample" inscribed on it. He is showing this to a Spanish don and his lady, both of them attired in the ancient national costume as handed down to us in the "penny plain, twopence coloured" prints of our childhood. Both the don and his lady are apparently horror-struck at sight of the sample-box, though why they should be I know not, and the lady in her fright is dropping a plate of grapes, melons and other fruits, while the countenances of the pair display the most abject 230 


\section{THE SONG OF THE CHEESE}

fear. Underneath the picture is the following

verse of the song:

“The Pennard Man went to the Hold

And brought up a Pennard Cheese.

Says he, 'You Spanish DoG, behold,

Thou'st no such Frutrs as THeSE!" ",

The first page of the music is headed-

\section{"THE ROYAL CHEESE.}

Made at West Pennard, Somerset, in one day, from the milk of Seven Hundred and Fifty Cows-fifty dairy maids officiating at the Ceremony.

This Song was sung on the occasion of Her Majesty's Nuptials in the room where the cheese is exhibited, and received with enthusiastic cheers. The Words (in part) by T. Dibdin, Esq.

The Musio by T. Williams."

The words are as follows :-

"A Pennard Man set sail for Spain,

To deal in merchandise,

No sooner he arriv'd there

Than a Spaniard he espies,

Who says, 'You English Dog, look here!

Rich fruits and spices fine,

Our Land produces twice a year,

Thou'st no such fruits in thine!'

"The Pennard Man went to the hold

And brought up a Pennard Cheese!

Says he, 'You Spanish Dog, behold!

Thou'st no such fruits as These!

Your Land produces twice a year

What proudly you display,

But such as now my hands do bear,

Our Lands give twice a day." "

Third Verse. (J.M.)

"Zeal fir'd each honest Pennard breast

When they this triumph knew,

And fifty blythe young Dairy Maids

Resolv'd some feat to do, 


\section{FIFTY YEARS OF A SHOWMAN'S LIFE}

To prove their Loyal heart-felt vows, What could they offer more!

Than 'Seven Hundred and Fifty Cows!' To yield their precious store.

Fourth Verse. (Written impromptu).

"These Pennard Dames then built a cheese, The Like was never seen!

'Twas made, and press'd, and fit to please, Our Gracious Lady Queen. And wedded to her Royal Love ! May blessings on her fall, And Pennard Cheese at Dinner prove The Best thing after all $l^{\prime \prime}$ 


\section{CHAPTER XXI}

A Wonderful Woman-A Valued Friendship-A Royal Recognition.

T 1895 I had the privilege of corresponding with, and afterwards of meeting on many

1 occasions, one of the most remarkable women of her time: the late Miss Eleanor Ormerod, of whom it is safe to say that no one of her sex ever rendered such valuable services to agriculture as she did. Born and bred on her father's property near Chepstow, she took a large share, as her father advanced in life, in the management of the farm and the estate, and this gave her that practical knowledge of agricultural affairs which enabled her, later on, to confer so great benefits upon the farming community. Becoming intensely interested in plant, insect and bird life, she directed her mind to seeing how she could best utilize her hobby for the common good. It did not take her long to realize what a plentiful lack of knowledge there was among agriculturists respecting their insect foes, and she set herself to work to rectify this by tapping every possible source of information and by systematizing and correlating what had hitherto been isolated facts. It seems incredible that before she took up the work there had been no attempt in this country at any continuous, methodical investigation of a branch of science so important to agriculture, 233 


\section{FIFTY YEARS OF A SHOWMAN'S LIFE}

or any steps taken to bring under the notice of those most interested how they might best combat the many enemies so destructive to the well-being of their live-stock and crops.

With her own unaided pen and her own unaided means she carried on for years, with the utmost efficiency, a work which in many European countries, in our Colonies, and in America, was conducted by departmental officials, ąnd at the cost of the State. Early in 1877 she issued a brief pamphlet, entitled Notes for Observations on Injurious Insects, with the object of exciting interest in the subject and inducing others to communicate to her their observations, following this up in the autumn by the first of those valuable reports, on injurious insects and common farm pests, which for twenty-four years appeared annually from her pen. In addition to this, she wrote many manilals and handbooks upon the subject, which were published at intervals. But what was most apparent to the public may be said to have been the least part of her beneficent work, for, becoming recognized as the great authority upon such matters, daily applications for information reached her from all parts of the world, and how she could ever successfully grapple, as she did, with her enormous correspondence was a subject of constant wonderment to all who knew her. When some special pest came to the front she took it in hand, and issued, gratuitously and at her own cost, thousands of leaflets of warning and direction. In order better to disseminate abroad her store of knowledge, she mastered half a dozen foreign languages, including Russian, and 


\section{ELEANOR ORMEROD}

at last, as multitudes of inquiries reached her from China, Japan, India, as well as from all Europe, Canada, the United States, South Africa, and Australasia, she was able to say, "My work now literally girdles the earth." For some time her letters averaged over 100 a day, and one of her pamphlets was circulated by her to an extent of over 40,000 copies. It is impossible to overestimate the value of her self-imposed and selfdenying labours, for her investigations into the attacks of the warble-fly alone saved cattleowners immense sums of money.

When the Bath and West Society accepted an invitation to visit St. Albans, in 1896, Miss Ormerod was residing there, and, with the sanction of our Council, I asked her to provide, out of her abundant stores, an exhibition illustrating the special study of her life, and this she kindly consented to do. Thus began an intimacy between us which only ended with her death. She had a personality of inexpressible charm, whilst her conversation showed a versatility of knowledge almost encyclopædic. She was at her very best in her own home, where she welcomed her visitors with an old-world courtliness and grace which was something quite out of the common in these free-and-easy days. Her correspondence was on similar lines, for she wrote, as she spoke, with a distinction ahd refinement indicative of the highlycultured mind. One of the most beautiful letters I ever received was in reply to one I wrote to her upon the death of her sister, the partner of her life. She was a deeply religious woman, and her letter, while it breathed a spirit of infinite trustfulness 


\section{FIFTY YEARS OF A SHOWMAN'S LIFE}

and patient resignation in her great sorrow, laid down in expressive terms the injunction to herself that she must not allow her thoughts of the dead to interrupt her work for the living; her strong sense of duty being paramount even in the freshness of an irreparable loss.

The sister in question, Miss Georgina Ormerod, was her inseparable companion and a worthy help-meet. This sister, in addition to being a scientist of no mean order, and a philanthropist in the best sense of the term, was an admirable artist, devoting her talents in this direction to the illustrating of her sister's investigations. Following the example of her sister, it was a labour of love with her to work for others, and many agricultural institutions have acknowledged their indebtedness to the skill and draughtmanship bestowed upon the drawings she presented to them. Yet, withal, she was the most retiring and modest of women, always, as it were, sheltering herself beneath the wing of her more famous sister, and only anxious to promote in the most unobtrusive way, the latter's work.

The practical way in which Miss Eleanor Ormerod gleaned information, and her appreciation of the most likely sources for obtaining it, are illustrated in her own words, which furnish a good example of her simple, unadorned English. "I had," she said, "willing helpers in the agricultural labourers-when they made up their minds whether they would assist or not. They had always helped, for we were on very friendly terms, and some of them or their children, like myself, had been born on the estate. But, 


\section{A REAL BENEFACTRESS}

though I did not know it at the time, I heard afterwards that when I asked for such special help they held a sort of informal meeting to consult whether it should be granted. Happily they settled that I was to be helped, because the Rural Council stated that I made use of what I got. The verdict was satisfactory in practical results, but I had my own private opinion that what were sometimes called "Miss Eleanor's shillings' helped the cause of collection."

The kind-heartedness of her services is well illustrated by an incident narrated by her medical attendant, Dr. Lipscomb, who said, "My sister was talking to a small market gardener in a flower garden she was sketching near Penzance, and Miss Ormerod's name happened to be mentioned. The old gardener was beside himself with delight to meet some one who knew Miss Ormerod. He said she had saved him from utter ruin. His flowers had become infested with some injurious insect, which bade fair to devastate the whole garden. In despair, hearing of Miss Ormerod, he wrote to her, and not only received a kind letter of advice, but also a copy of her 'Injurious Insects,' with the page turned down, and the paragraphs specially applicable to the case marked. No. wonder the poor old chap, with tears in his eyes, said he loved his unseen benefactress.."

Miss Ormerod not only complied with the wish I have referred to by providing and arranging a most valuable and interesting collection of entomological specimens and drawings in connection with the St. Albans Show, but she also attended daily to explain and answer inquiries upon the subject. 


\section{FIFTY YEARS OF A SHOWMAN'S LIFE}

Although she looked for no reward beyond the thought that she was doing some useful work for her fellow-creatures, she did not the less appreciate any little attention or any kindly recognition of her labours. Therefore, when the late King and Queen Alexandria, then Prince and Princess of Wales, visited the show, I asked our President (Lord Clarendon) if he would suggest to the Royal party a visit to the gallery over which Miss Ormerod was presiding. The Prince and Princess, with their daughters, gladly acted upon the President's suggestion, and spent some time in the building, deeply interested in all Miss Ormerod had to tell them. Both Prince and Princess, with the genial good nature which never failed them, conveyed to Miss Ormerod their cordial appreciation of her work in a way which greatly delighted her, and she assured me that the interview would always be one of her most happy memories.

Miss Ormerod received many honours from foreign and other public bodies, and the Bath and West Society conferred their honorary membership upon her and her sister, whilst almost the last distinction bestowed upon her was the honorary degree of Doctor of Laws in the University of Edinburgh, this being the first occasion on which the University had ever admitted a woman to this degree. The Dean of Faculty, on presenting her, truly said of her: "Her labours have been crowned with such success that she is entitled to be hailed as the protectress of agriculture and the fruits of the earth-a beneficent Demeter of the nineteenth 


\section{A SPLENDID RECORD}

century." Had she been capable of self-advertisement, which she was not, her splendid record of beneficent work must have received some official recognition of a national character. But she will live in the memory of those who could understand and appreciate her self-denying life as one of the greatest benefactors to agriculture the world has ever produced, and one of the most remarkable women of the nineteenth century. She died in 1901, and, as I have never ceased to value the privilege of knowing her, I could not well omit her from my budget of old memories. 


\section{CHAPTER XXII}

Some Show Yard Incidents-The Lord and the Muck Cart-Horse Shoeing-Liveried Splendour-A Watchful Goose-A Missing Picture.

GOOD deal of criticism has from time to
time been devoted to the subject of
show expenditure, but it must be borne in mind that the standard of living has everywhere gone up, and the fact that few of us are content to live as our fathers did before us is as applicable to societies as to individuals. Then, again, there has been in recent times a considerable rise in the cost of many indispensable things, including labour, so that you cannot build your show yard as cheaply as you used to do, whilst, at the same time, we have become more exacting and precise in matters of detail. For instance, when I was first connected with shows, a show yard was regarded as a naturally untidy spot, and any attempt to clear up its ordinary litter was considered an unnecessary piece of work. Now it is a matter of pride with every steward that each day, before the entry of the public, his department shall be as clear of straw, paper, and general rubbish as a croquet lawn. This means a daily expenditure for horses, carts, and men far beyond that formerly incurred. The show buildings, 
too, have to be more spick and span, more carefully finished, and more weather-tight than formerly. I do not think such additional expenditures as these are to be deprecated, provided that they are not earried to an extreme, because they are conducive to order and method, but, from a financial point of view, they do not bring any material grist to the mill in the shape of gate money. After all, the best excuse for a spending proclivity is an income that will admit of it. If we can afford luxuries, we may indulge in them within the bounds of reason; if, in the end, we have to retrench we must be careful to cut off superfluities and not necessities.

Agricultural shows have something to recommend them from a social point of view, for, whilst they provide a rallying point for the elements which go to make up our rural populations, they bring the urban inhabitant within the radius of such influence. Town and country " rub shoulders" in a show yard, and anything that can help the former to a fuller comprehension of the latter's work, and a juster appreciation of his difficulties, must be in no small degree beneficial. It is not unnatural to suppose that the sight of such types of animal life as are to be found there may have a desirable educational influence upon the mind of the borough voter; may extort from him some admiration of the skill and patience which have assisted to produce such results; and may help him to a better conception of the value of our native flocks and herds than he previously possessed. By a natural train of thought this may remind him of the necessity 


\section{FIFTY YEARS OF A SHOWMAN'S LIFE}

of safeguarding them from disease. Pleasure fairs are rapidly dying out, but our agricultural shows illustrate the doctrine of "the survival of the fittest," and continue to flourish as popular holidays; at least, they did before the war, and will do so again when peace returns. Now, though, of course, no one would for a moment argue for their continuance if they fulfilled no higher purpose than providing occasions for mere social gatherings, in any plea for their existence it may be pointed out that they do represent popular holidays - and no nation can afford to dispense with these-which can be enjoyed without a suspicion of harm, and with every probability of accruing benefit. I have many a time mingled with the dense crowds thronging a show yard on a Bank Holiday, and have been struck with the remarkable good temper and good order everywhere prevailing. The police have frequently corroborated this, and a case of drunkenness is quite exceptional.

A factor-not by any means the least-in the success attained by the agricultural show system must not be left out of the reckoning, especially by one who has had so prolonged an opportunity as I have had of learning how much it represents. Every show secretary can testify to the value of the "spade work" done, without fee or reward, with so much energy and enthusiasm by the committee and stewards of a show. This free gift of good service once, at least, in my experience extorted a spontaneous tribute of admiration from an unexpected quarter. I remember on one occasion the work of removing the debris 


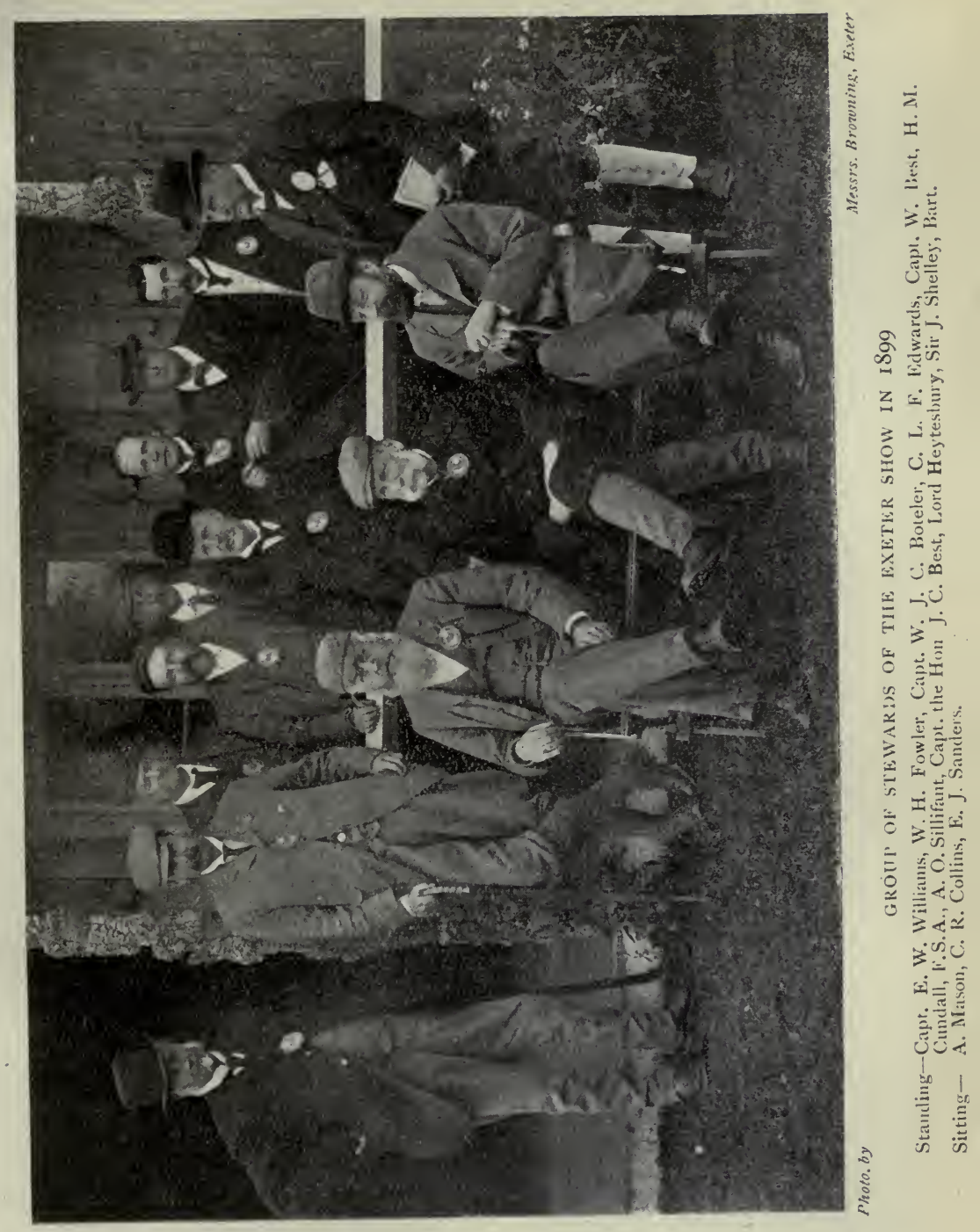





\section{A PEER AT A MUCK-CART}

in a section of our show yard somewhat lagged as the hour drew near for its completion. The responsible steward-a peer of the realm and an indefatigable worker, now the Lord-Lieutenant of his county and a K.G.- - being keenly anxious that his department should suffer no discredit, personally and energetically assisted in the clearing up. Hard by was a herdsman in charge of stock, who viewed this proceeding with open-mouthed astonishment. Anxious that others should enjoy such a spectacle, he hailed, in excited tones, a brother herdsman, with "Come 'ee 'ere, Billcome 'ee 'ere! 'Ere's a real lard a-loadun a muck-cart." Then, again, the Society on another occasion took advantage of the fine collection of dairy cattle at the show to carry out a series of tests with the object of ascertaining the quality and quantity of butter obtainable from the milk of different breeds of cattle. The entries were so large, and the tests so exhaustive, that it was at one time feared that the investigations would not be concluded before the show came to an end, so the order went forth "all hands to the churns." Then the High Sheriff of Somerset -who at the present moment is doing yeoman service as Chairman of the Somerset County Appeal Tribunal-and who was steward of tests, buckled on, not exactly his armour, but professional dairyman's attire, and, for some hours on Bank Holiday, might have been seen churning away for all he was worth. Whilst these little episodes have their humorous side, they are to onlookers a practical realization of the universal kinship of labour and a tangible embodiment of 


\section{FIFTY YEARS OF A SHOWMAN'S LIFE}

the principle that no one need ever be ashamed to put his hand to an honest job. So long as societies can rely upon voluntary effort exercised in such a spirit we can have little fear for their vitality.

The Bath and West Society was one of the first agricultural associations which recognized horse-shoeing, and found a place for it in its show yard, and for many years past competitions of smiths have been a prominent feature of the annual show. Whilst they have fostered a spirit of emulation in the smiths, they have helped to spread a knowledge of the correct principles of shoeing by affording practical illustrations of what constitutes good workmanship. Of late years they have been made still more educationally useful by an exhibition of horses' hoofs, illustrating various methods of shoeing, good, bad and indifferent, and of examples of abnormal feet, with an expert at hand to explain matters.

The appreciative interest shown in the competitions by farriers and their apprentices induced the Society to formulate a scheme for providing systematic instruction in shoeing. It consisted of a migratory school on conditions generally analogous to those in force for the Society's Butter School. A travelling van was provided, in which the forges, anvils, etc., were housed, and the teaching was conducted by a mastersmith, who had previously been awarded many prizes in open competitions, whilst a qualified veterinary surgeon lectured to the classes upon the anatomy of the horse's foot and other farriery subjects, and acted as general adviser upon the 


\section{A FARRIERY SCHOOL}

work of the school. The school, which the Society carried on for the Somerset County Council, moved from place to place, and at the conclusion of each course of instruction a competition of the students was held. The wide influence the school exercised may be inferred from the fact that during its career from 1895 to 1901 inclusive, it visited eighty centres, whilst 453 smiths went through courses of instruction.

The success of the school was largely due to the keen interest taken in it by the Society's steward, the late Lord Wynford, who visited the various schools from time to time and addressed the classes. He brought to the work a genuine enthusiasm for it, expert knowledge and experience, and a straightforwardness of purpose, which specially appealed to the class of workers with whom he had to deal. I travelled many miles with him when we were following the school about, and this companionship inspired in me a real regard for his high qualities and a deep sense of a personal loss when he was called hence.

By far the most gorgeous and flamboyant procession that ever entered the Bath and West show yard was seen at the Society's St. Albans meeting, when the Lord Mayor and Sheriffs of London paid a State visit to the show. As a display of gold lace, cocked hats and silk stockings it was unsurpassable, whilst the august dignity of deportment of all concerned left nothing to be desired. The trio of equipages were in splendour on a par with those occupying them, and the horseflesh was worthy of the occasion. The entourage of the party of English and foreign 


\section{FIFTY YEARS OF A SHOWMAN'S LIFE}

royalties, including our Heir-apparent and his Princess, who visited the show a day or two later, was, from a spectacular point of view, completely outshone by the civic turn-out. On behalf of all concerned, I conveyed to all three dignitaries our deep sense of the honour they had conferred upon the Society by their visit. But it had not occurred to me to express our obligations to the magnificently-attired individuals who shed listre upon the proceedings as coachmen and footmen. My remissness in this respect met with its rebuke, for a few days afterwards I received an epistolary communication from one of these civic attendants reminding me that it was customary always on such occasions for the persons visited to present each coachman and footman with a fee of $10 s$, and requesting that it might be forwarded. On inquiry at headquarters, I ascertained that such an acknowledgment was customary, but it was suggested, as a compromise, that I might cut it down to $5 s$. or $3 s$. $6 d$. per head. I felt, however, I could not possibly offer such splendidlyattired personages anything less than gold without giving serious affront. At the same time, as the functionaries in question had done nothing for the show beyond either driving or strap-hanging on to their masters' vehicles, I did not feel called upon to help pay their wages. So I held my hand, instead of putting it into my pocket, and no County Court was troubled with any action compelling me to disburse. I thought it was one of those ancient customs more honoured in the breach than the observance. I felt, too, that, if anyone was entitled to be paid for coming 


\section{A REPROVING JEAMES}

to the show, it was the principals, his lordship and the sheriffs, and they had made no claim. Of course, this happened years and years ago, and no doubt, with the modern reforming zeal of the city, such attempted levies have long since been swept away.

I did not take this implied rebuke from the liveried gentlemen particularly to heart, because I did not consider I deserved it. But I was once completely crushed by a superb specimen of the genus flunkey, and it has dwelt in my mind because I know I deserved it on account of the faux pas I committed. Once when I was young and comparatively innocent, being nothing better than a struggling showman, I had occasion to call upon a peer of the realm. In response to my gentle ring, the hall-door flew open, and there stood on the threshold, looking down upon me, one of the very finest powdered and silkstockinged wearers of livery I ever beheld. Taken off my guard by the dazzling vision, in the mildest of accents I innocently inquired, "Is his lordship in ?" Then Jeames-de-la-plush drew himself up, and in the loftiest of tones replied, "Is lordship is in, but he may not be at home."

One of the best-remembered and most attractive of the stories which helped in one's young days to enliven that catalogue of many crimes described as Roman History was the one which has conferred immortality, as a night-watcher, upon the goose, inasmuch as it was a flock of geese, which, by arousing the slumbering guard, saved Rome when the enemy was at its gates. One has sometimes thought that so captivating 


\section{FIFTY YEARS OF A SHOWMAN'S LIFE}

a story was either too good to be true or that the geese in question were of an abnormallygifted type not to be met with elsewhere. At the Bath and West Show at Truro, however, reliable evidence was afforded that this wakeful attitude, as well as the acuteness to turn it to account, was not the appanage solely of the geese of the Capitol. With a view to the better protection of the poultry under his charge, the foreman of that department always occupies a timber-built bedroom adjoining the poultry-tent. On the night in question his slumbers were broken by the excited hissing in the adjacent tent of a prize gander, who was evidently greatly perturbed about something. So persistent and vehement were the demonstrations, that the foreman turned out of bed to see what was the matter. He then found that the intelligent bird, with a view to eventualities, was evidently in the habit of sleeping with one eye open, and so was enabled to spot two robbers of hen-roosts, who were foraging for eggs. With the sagacity of a well-trained watch-dog, the gander at once gave the alarm, and the offenders were pounced upon. On being afterwards interviewed, the foreman, well-known in poultry circles as Sam Melhuish, said that he knew of no better watchdogs than geese, for they were so highly-strung that the least symptom of anything unusual at night was sufficient to put them into a flutter of excitement, and their one desire then was to call everybody's attention to what was going on. As Sam's knowledge of the manners and customs of poultry is encyclopædic, this may be safely accepted as gospel. It is comforting to believe 


\section{SIDE SHOWS}

that the geese of our own day are preserving that spirit of intelligent alertness characteristic of their Roman predecessors.

I have alluded to the cosmopolitan character of the Bath and West exhibition, and among other of its attractions not commonly found at an Agricultural Show was, for many years, an exhibition of paintings. This was merely a development of one of the Society's original objects which, as defined by its founders, was " the encouragement of Agriculture, Arts, Manufactures and Commerce." In its very early days, it recognized art by the awarding of a gold medal to Chantrey, the sculptor, and in other ways paid tribute to it. In years gone by, when art had much less recognition outside the rich and cultured classes. than now, country-folk had but few opportunities to enjoy works of art. In later times, the establishment of municipal art galleries and increased travelling facilities, induced the Society's Council to believe that there was no longer the same reason as heretofore for recognizing art in this particular way. So now, instead of the pictureshow, there are exhibitions illustrative of arts and crafts and of the work of Technical Schools and similar institutions. Nature-study exhibitions and collections representing the work carried on by various educational authorities and examples of home industries have also been useful additions to the attractions of the show yard.

In connection with the picture exhibition, a somewhat embarrassing incident occurred on one occasion. It was when the show was held at Dorchester, and was visited by the late King, 


\section{FIFTY YEARS OF A SHOWMAN'S LIFE}

then Prince of Wales. His Royal Highness inspected the picture gallery among other departments of the exhibition, and had no sooner entered the gallery than he asked to be shown a picture, painted by a lady whose name he mentioned, and whom he had been given to understand was among the artists represented in the gallery. Owing to the fact that we had always more pictures sent in than there was space for in the building, a selection had to be made by the hanging committee of those best fitted by their intrinsic merits for exhibition, the rejected ones being stowed away in an adjoining building free from the glare of publicity. Included among them, of course, was a certain proportion of artistic mis-fits - to describe them by as mild a term as possible-hence, the shrine containing them was known as the Chamber of Horrors. On this occasion some of the horror was transferred to the officials of the gallery itself when it was realized that a picture, upon a sight of which the Heir-Apparent had set his heart, had actually been included among those rejected, and was wasting its sweetness on the desert air of the Chamber of Horrors. Of course, it had to be produced somehow, and was found to be a Study of Dogs and to be no worse than are many other portraits of canine favourites. The artist evidently had a friend at Court who appreciated her talent, and the Prince, with his proverbial good nature, was ready enough to do her a good turn by displaying a knowledge of her work. Possibly, too, the aforesaid Court-friend may have marked the absence of the picture from the gallery and used 


\section{A FALSE PROPHET}

his or her influence to induce an inquiry with a view to rectifying this, for, of course, room had to be found for the work after Royalty had paid this tribute to the painter.

The picture exhibition was not only a humanizing influence, so far as the general public were concerned, but conferred an advantage upon many young artists by providing a market for their works. The sale of these was stimulated by an Art Union, the winners of prizes selecting their prize from the pictures exhibited. The amount realized by the sale of tickets, supplemented by an annual grant from the Society of $£ 100$, was devoted to the purchase of pictures for prizes. I took tickets always with clockwork regularity, but, no matter whether I took many or few, invariably with the same non-starter result. Quite early in life I abjured all lotteries, raffles, draws, sweepstakes, and such-like vanities, barring the Art Union in question, not on conscientious grounds, but simply because I always drew a blank. However, I had to break through my rule on one occasion, when, as Mayor, I had to preside at the drawing of the prizes of an Art Union in connection with an exhibition at Bath of pictures by West Country artists. In a short address, and with a view to stimulating a few laggards to invest in tickets at the last moment, I dwelt upon the fine chance every one who invested a shilling had of securing a valuable work of art. I was careful to point out that, although I was in the chair and that the Committee had requested a daughter of mine to act as the drawer of the prize numbers, no one need 


\section{FIFTY YEARS OF A SHOWMAN'S LIFE}

fear that, even with these advantages in my favour, there was the remotest possibility of my winning anything myself, thereby reducing other people's chances of doing so, because my proverbial ill-luck when lucky bags or their equivalents were deciding factors rendered it absolutely out of the question for Fortune to bestow upon me anything but a blank. Soon after I had made this remark my daughter took her place at the wheel, and one of her first acts was to draw a prize for her father; a most suspicious circumstance, and one which discounted all I had said. This incident does not properly come within the area embraced by these reminiscences, except that it points a moral equally applicable to Showmen as to Mayors, viz., never, as Artemus Ward has told us, to prophesy unless you know for certain. 


\section{CHAPTER XXIII}

Some Echoes of the Past-A Surprise Packet-Apple Grafting-How the Secretary was elected in old time.

T pursuit of the collecting hobby, to which I have already referred, I was once favoured in a remarkable way by chance, for had I formulated a design to obtain what fell into my hands by pure accident, the odds were a thousand to one against its effecting its purpose.

At autograph sales, persons, who, like myself, are bounded by certain obvious limitations, have, when commissions are being executed for American millionaires to stand passively by. One has then to rest content with being merely "a snapper up of unconsidered trifles," described in the catalogue as "parcels." These are budgets of old letters, mostly from ordinary folk, with "a sporting chance" of something from a distinguished somebody being inadvertently mixed up with them. I gratefully acknowledge that the realization of such hopes is not entirely outside the sphere of my own experience. "A nod is as good as a wink" to an auctioneer, especially when there is a lack of responsiveness among the bidders, and so once upon a time the slightest inclination of the head secured me the possession of a "parcel." The dealers, intent upon higher game, hardly condescended to cast an eye at such speculative lots, and they fell to me at a price which enabled 


\section{FIFTY YEARS OF A SHOWMAN'S LIFE}

me to feel that I was riding a hobby without any undue risk of coming a financial cropper in consequence. I had no reason for thinking my purchases would yield any particular treasures, but I looked forward to their affording me a pleasant hour or two in their company. The letters themselves had the stamp of a respectable old age plainly impressed upon them, for the mellowing hand of time had turned the paper yellow and the ink brown. Neither did they lack that pleasant aroma-pleasant at least to delvers in antiquarian depths-suggestive of so many possibilities, but which those who care not for such things prefer to describe as " a musty fusty smell."

On examining my purchase at leisure, I had a pleasant surprise, for what should I find but a letter written by Nehemiah Bartley, one of my predecessors in the office of Secretary of the Bath and West Society, and addressed from the old headquarters of the Society, Hetling House, Bath. This fine old Tudor mansion, which housed the Society and its belongings in its early days, is still devoted to worthy objects, being now the Abbey Church House, I may add that in the same bundle of old letters were several others of considerable interest referring to social matters occupying attention during the latter part of the eighteenth century.

The letter in question, which bears the date January 7 th, 1802, is addressed to the fifth Earl of Berkeley, who was Lord Lieutenant of Gloucestershire and of the Cities of Bristol and Gloucester, and, in view of the interest manifested of late in everything relating to the 254 


\section{APPLE-TREE GRAFTING}

production of cider, it seems worth while to pay it the compliment, after its long rest, of bringing it into the light of publicity, so here it is :

"MY LoRd,

"I had the honour of your Lordship's letter to my Lord Somerville transmitted to me by that Nobleman, in reference to an improved method of grafting the Apple Tree, in a communication to the Bath Society by a Mr. Travers, of West Camel, near Sherborne, Dorset. His object in this method is to facilitate the growth of the tree from the Kernel Stock so as to bring on to maturity of bearing an orchard much sooner than by the usual practice in grafting, namely, as he conceived about 7 years.

"His words are these: "The quickest way to get an Orchard is to sow the Apple Kernels in March. The March following take them up and graft them in the same way as those two that I have sent, planting the grafted part 3 inches under ground. I have had Apples the third year from the Kernel by this way of grafting, and they will make trees 7 years sooner than by the common way of grafting.'

"From some practice and observation of my own, my Lord, I incline to think that Mr. Travers' ideas are pretty correct thus far, but he is silent as to any effect thus to be produced in renovating the lost prolificacy of the famous old sorts of Cider Fruit as the Styre, Woodcock, Carraway, Russet, Coccagee, etc., and I have my fears that such an effect is not by any means very likely to be produced.

\section{5}




\section{FIFTY YEARS OF A SHOWMAN'S LIFE}

"It appears to me that the practice of grafting, even in the first instance, is in some sort a receding from Nature, and that every subsequent operation is in progressive departure to a final termination in utter degeneracy.

"If this be so, there seems to be no effectual remedy. But, by recurring to the Seed or Kernel of the Styre, for instance, it might not be improbable to select varieties nearly approaching in value to the original, or perhaps to equal it.

"It is well known that the varieties thus produced are almost next to infinite. I would, however, always studiously prefer to propagate from well-known choice sorts, for, astonishing as these varieties are found to be, they almost invariably bear something of the character of the parent.

"I am well aware that this sort of reasoning completely applies to the propagation of the potato in particular, which, being an annual plant, its degeneracy in regard to prolificacy appears within a very short period from the seed perhaps of 10 or 12 years when the propagation is continued by cuttings from the bulb.

"I am sorry, my Lord, it is not at present in my power to speak more satisfactorily on this subject.

"I should certainly experience the highest degree of gratification if on any future occasion any communication of mine might be in the slightest degree acceptable to your Lordship, having the honour to subscribe, my Lord, as your Lordship's most respectful and truly obedient servant.

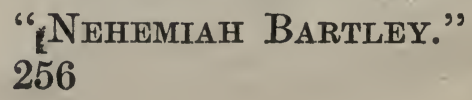




\section{FRUIT GRAFTING}

I have endeavoured to ascertain whether the system of grafting referred to was ever seriously adopted, and the late Mr. Radcliffe Cooke, M.P., who did so much in promotion of the cider industry, and who had so intimate a knowledge of all pertaining to it, informed me that Rudge's Agriculture of Gloucestershire contained an account, drawn up in 1807 for the consideration of the short-lived Board of Agriculture of that period, of a method of grafting very similar to the one in question. It is there stated to have been discovered and practised by Richard Brown Cheston, M.D., of Gloucester, and to advance the growth and fruiting of the trees by many years. Mr. Cooke in a communication to me said:

"The doubt expressed by Mr. Bartley of the efficacy of grafting or budding in securing the continued propagation of any variety of fruit was probably raised in his mind by perusal of Mr. T. A. Knight's publications on fruit, in which he holds the theory that every variety of fruit has a fixed period of existence and can endure no longer, whatever endeavours may be made to continue it by grafting, budding, or the like. Mr. Knight's theory had a great vogue at the time owing to his reputation as a pomologist and horticulturist, but experience has long since exploded it. Many sorts of cider apples and perry pears which Mr. Knight thought then, i.e., 100 years ago, to be on the verge of extinction are still as vigorous as ever in young trees, the result of grafting or budding. Indeed, a well-known dessert pear, Knight's Monarch, which he himself raised by cross-fertilization, ought by his theory 


\section{FIFTY YEARS OF A SHOWMAN'S LIFE}

to be now extinct, whereas young trees are in every nurseryman's catalogue."

I may add that I have not been able to refer to the communication mentioned in Mr. Bartley's letter, made by Mr. Travers to the Bath and West Society, as for a reason, to which I shall presently refer, the Society's records were very imperfectly kept at that time.

The deterioration of the potato, referred to in the letter, has been written about of late as though it were a recent discovery, whereas the letter shows that it was a subject of remark long ago.

"This fond attachment to the well-known place Whence first we started into life's long race."

It is curious to find, as is not infrequently the case, that, after a lapse of many years, relics of an almost forgotten past have a knack of finding their way back to their native soil or its equivalent, as though they were not altogether insensible to the homing instinct. One wonders in what company and in what places my predecessor's letter had been since it was first dispatched from Hetling House under conditions of postage so different to those at present prevailing? How did it secure such a prolongation of existence as to live to be knocked down in a London auction room more than a century after its birth, and how many chances were there against its ever finding a haven of rest so congenial as the sheltering roof of the old Society, to whom it primarily owed its being? But, if we know so little of the happenings to the old letter, the Society's minute 


\section{THE VACANT SECRETARYSHIP}

books can tell us something about its writer, and in doing so incidentally illustrate the quaintness -as it appears now-both of phraseology and procedure characteristic of the period.

The curious circumstance of a letter written so long ago by one of my predecessors falling into my hands, induced me to look up the circumstances under which Nehemiah held office, and they are sufficiently amusing to be worth recording.

On January 28th, 1800, Wm. Matthews, who succeeded the founder of the Society (Edmond Racik) as secretary, stated in a printed circular to the members that "personal considerations of much importance to myself disposing me to resign, though with reluctance, the office of secretary, I am sanctioned by the under-written vice-presidents in announcing the same." The circular proceeded to call a general meeting to select a new secretary, and concluded with a comically-worded injunction to candidates for the post, signed by three vice-presidents: William Falconer, John Billingsley, and (Sir) Benjamin Hobhouse. They were all men of note, the firstnamed being an eminent physician and scientist and a Fellow of the Royal Society, whose knowledge was varied and profound; the second, the author of $A$ General View of the Agriculture of Somerset and other works ; and the third a distinguished Parliamentarian, a voluminous writer, and a good friend to agriculture, who acted as President of the Society for a period of thirteen years. His bust - a beautiful work of art-by Chantrey, is to be seen at the. Society's offices. The injunction was as follows :- 


\section{FIFTY YEARS OF A SHOWMAN'S LIFE}

"To prevent as much as possible unnecessary trouble, persons, not well qualified by literary and other suitable abilities, are hereby cautioned against attempting to canvass the members for support on this occasion;" while persons, whose genius and qualifications can be duly attested, are equally encouraged to come forward. The station is to be considered as requiring confinement, care, and diligence."

In view of the number of people who regard themselves as fully equipped so far as "suitable abilities" are concerned for most offices from that of Prime Minister downwards, it is to be feared that the caution to unqualified persons not to present themselves would not be a material deterrent nowadays to many candidates; whilst the invitation to come forward addressed to those who, in the estimation probably of "their sisters, their cousins, and their aunts," are accredited geniuses would at the present time be more than sufficient to ensure an ample supply of applicants. Personal experience leads one to appreciate the desirability of "care and diligence" in the discharge of the duties, but why "confinement"which means, I suppose, a disposition to endure it-whether solitary or otherwise, should be put in the forefront of the requirements is not so clear, unless it were intended as a hint that the secretary was to stick to his desk and not go gadding about the country. It is sad to reflect, as will shortly be seen, that all these precautionary injunctions were apparently futile in their effect.

A general meeting of members was held on February 11th, 1800, for the election, and two 260 


\section{ELECTION OF SECRE'TARY}

candidates were formally proposed and seconded: Mr. Bartley and Mr. Woodford, the former being described as a nurseryman, of Lawrence Hill, Bristol, and the latter as an attorney, of Bath. The minutes of the meeting state that "the members present, 39 in number, exclusive of the Chairman, proceeded to ballott, the door being first bolted; on which last account, as it afterwards appeared, a considerable number of the declared friends of $\mathrm{Mr}$. Bartley were accidentally excluded from voting." The result of the voting was the election of $\mathrm{Mr}$. Bartley by 29 votes to 10 , so that, happily, the barring-out process did not affect the result, though, if the voting had been the other way, the proceeding might have been viewed with some suspicion. It is difficult to comprehend why it should have been considered necessary to lock everybody in before they voted and to take such care to keep out late arrivals. This appears an excess of caution, unless there was an anticipation of an undisciplined horde of non-members "rushing" the meeting room. Notwithstanding the preponderating support he received, Nehemiah, unfortunately, was not a success; his besetting sin-an unpardonable one in a Secretary, by the way-being incurable laziness. Though the Society bore this with Christian patience for some time, the limit of human endurance was reached in 1805, when lazy-bones was given his congé; possibly the "confinement" sapped his vital energy, or more probably, being a nurseryman, he regarded the condition as applying more to his own garden than to the Society's offices. 


\section{FIFTY YEARS OF A SHOWMAN'S LIFE}

One of the indictments against him was that during the whole of his term he had never issued a volume of the Society's Memoirs, although hitherto these had appeared every two years; these Memoirs being the progenitors of the present Journal. This will account for my inability to discover them for the year in which Mr. Travers' paper on grafting was written.

The Society has a very artistically-executed pastel portrait of William Matthews, Nehemiah's predecessor, already referred to, in the office of secretary. He is represented brimful of life, just looking up from the act of writing a letter in order to reply to some interrogatory just addressed to him, his expression of confidence indicating that he had a complete answer to it whatever the query might be. His pen is in his hand, and the other implements of his calling, as they were in those days, are depicted. They include a quill-pen, rarely seen now, a pounce-pot with its grains of sand, fulfilling the purpose of the after-invented blotting-paper, a stick of sealing-wax, a taper, and a selection of variously-coloured wafers for securing correspondence before adhesive envelopes superseded them. 


\section{CHAPTER XXIV}

A Showman's Letter-bag-Some Epistolary Singularities.

A SHOWMAN'S letter-bag contains as many 1 caligraphic curios as a sea-trawler's net account for the geographical confusion of mind of the inquiring spirit who wrote to ask me whether Croydon, where the show was to be held one year, " is in Bath or the suburbs of London," or for the capacity for logical inference of the shoeing smith, who wanted to know whether he was eligible to enter in the class confined to competitors twentyfive years of age and over as well as in that open only to those under that age. Most singular motives are attributed by disappointed exhibitors to both societies and judges. The dairy-woman of a distinguished Parliamentarian could not account for his lordship's butter-which was of such superior quality-not receiving a prize on several occasions unless it was because he was "a Liberal"; so she writes to ask me whether this was the reason. This might have been intended as a warning that the eye of Parliament was on us, because at the same time she once more makes an entry on his lordship's behalf for the forthcoming show, with the remark that she hopes on this occasion his lordship would be successful. 


\section{FIFTY YEARS OF A SHOWMAN'S LIFE}

On my gently reproving her for supposing that politics had anything to do with it, my correspondent sent me a reply which she regarded as conclusive evidence for the defence. It stated that a lady friend of hers on one occasion was wearing the Liberal colour when she met somewhere or another one of the Society's stewards, who said she was wearing "the wrong colour." The lady repudiated the soft impeachment, disowned any Liberal sympathies, and avowed that she wore the colour in question simply " because it suited her." This seemed somewhat slender evidence for imputing political animus to a different party altogether. Another letter desired to be informed why some of the principal prizes "were given to Mr. Rothschild, a Jew, instead of to British exhibitors."

Some exhibitors, with a simplicity worthy of a better cause, will calmly put into writing a proposal for the secretary to join them in transactions of the shadiest character. A letter before me is a sample of this. It informs me that the writer has a two-year-old filly, "which has done rather bad this winter, but if the entries are very bad in the class I would enter her, but only in case the entries are very, very small. I shall keep this to myself entirely." Doubtless he would, so far as the conditions mentioned are concerned, but a prize at a leading show for a " rather bad" filly in "a very, very small class" would be a better advertisement for the exhibitor than for the Society.

One gets some distinctly original expressions in letters, and the correspondent who says "I 264 


\section{EPISTOLARY SINGULARITIES}

am sorry to say I did not get inflamation of your show" would be entitled to congratulations if he were taken literally, but experience tells us that he meant something quite different to what he wrote. The same remark applies to a newspaper editor, who petitions for news of the show "that we may editorially tootle a pleasing melody." This is a less crude and much more musical term than "boom," though, from what I know of editors, I should say that a trumpetblast better represented their utterances than a mere tootle.

Another instance of an unintentional aptitude to say what you don't mean is afforded by a letter I have from a show steward of another Society. I had asked him whether the supplying of refreshments at his show by a certain lady caterer was satisfactory. He replied that he did not patronize that particular refreshment pavilion, but that "Miss Brown always looked clean and was wellfilled whenever I passed." By omitting to say that it was the pavilion he meant and not the lady, he conveyed the impression that the latter was not sparing of her ablutions, and showed unmistakable signs of catering liberally for her own interior. It reminds one of the elder Weller's description of the "young 'ooman" whose tealibations were so lavish that, as he expressed it, "she's a-swellin' wisibly afore my werry eyes."

Shakespeare has told us that "one touch of nature makes the whole world kin," and a letter which once reached me supplied the touch. It was the appeal of a young couple, the proud proprietors of a baby in arms-probably the first- 


\section{FIFY YEARS OF A SHOWMAN'S LIFE}

who were most anxious to visit the show, but the difficulty-quite properly explained-was that the infant was unable to sustain itself without nourishment, which was derived from Nature's source, for more than two and a half hours together. More delicately-minded than many, they could not bring themselves to conduct the feedingprocess in the full glare of publicity, and yet they could not do justice to the show if they had only two and a half hours of it. Even Showmen are human, and I was not proof against such an appeal, so an arrangement, providing for full privacy and satisfactory to all parties, including the baby, was arrived at.

A secretary's post-bag, especially when its contents refer to so many-sided a show as that of the Bath and West Society, is sure to afford a few problems, the solution of which is not apparent on the surface. This was the case when one morning, at breakfast, I received a letter from a dairymaid, who had previously entered for the butter-making competitions without contributing the necessary fees. In the letter in question, with which no fees were enclosed, she thanked me for giving her credit, and said she had sent the cash on to-day, enigmatically remarking, "You will find if you seek." This suggested a sort of "hidden-treasure hunt," which I was much too busy just then to undertake. I, therefore, commenced in my mind to draft an epistle to the young lady, inviting her to give me some clue as to the whereabouts of the twenty-five shillings she owed. In the meantime my betterhalf casually remarked that some one had kindly 


\section{"TAKE CARE OF THE BUTTER"}

sent us a present of butter. I said I hoped it was not a veiled attempt to bribe the secretary, as, if the dictum, often wrongly ascribed to Walpole, that "every man has his price" were correct, I must have something better than butter. I then went to the office, and began dealing with the morning's correspondence. When I had got half-way through my directions with respect to the way in which the dairymaid should be handled a sudden thought flashed through my "brain; and, instead of continuing to dictate something suitable to the situation she had created, I dispatched a hasty note to the partner of my life, begging her to take the utmost care of that butter, and to do nothing with it till I came home for lunch. There was just the fear in my mind it might be given away or otherwise disposed of before I could investigate it. However, it was preserved intact for my inspection, and a careful disintegration of its innermost parts revealed various coins, amounting in all to five-andtwenty shillings, dispersed about the oleaginous mass. . The young lady, either from a love of mystery, or a desire to save the cost of a postal order, had adopted this singular, but somewhat risky, method of conveying her fees to the proper quarter. It seems worthy of record as an example of misplaced ingenuity. 


\section{CHAPTER XXV}

Cloud and Sunshine-Some Show Yard Trials-The Kilburn SloughThe Smithfield Fog-A Cornish Gale-The B. \& W. MessRelics of the Past.

T F I have dealt in a somewhat light-hearted spirit with some of the incidents of a show-

1 man's career, it must not be inferred that it has not its trials and anxieties, but these are not alleviated by taking either them or oneself too seriously. However much one may endeavour to look ahead, or, as a Parliamentarian once put it, display "an intelligent anticipation of events to come," there are always lurking possibilities of unforeseen contingencies, capable of upsetting all human calculations. In a show yard, Nature herself is very good at lending a hand to give point to the ancient reminder that "the bestlaid plans of mice and men aft gang agley." It can be safely said that Nature, as represented by weather, has been a source of more anxiety to showmen than all other influences combined, without excluding even swine-fever, which has had an unhappy knack of making its presence felt on the eve of a show, with the natural corollary of a sheaf of Government orders perplexing to those who have to act upon them, and fatal to the porcine section of the exhibition. But meteorological conditions, speaking generally, have a more powerful effect upon the $\mathfrak{E}$ s. $d$. side of a show than 


\section{THE KILBURN SLOUGH}

anything else I wot of, whilst I know of few more pathetic sights in this world than a bevy of holidayseekers striving to be "merry and bright" when struggling through a sea of mud in the midst of a pitiless downpour.

The historic Kilburn Show of the Royal Agricultural Society in 1879 touched the zenith of watery desolation, and happy were those individuals who, appalled at the sight which met their eye as they passed through the gates, turned tail, as many did, at once, and made for home. Happier still were others who, like myself, got no farther from their home than the local railwaystation, and then, thinking better of it, returned to the bosom of their family. We never had anything at the Bath and West Show to compete with Kilburn in misfortune. We have had traction-engines embedded in the native soil for a day or so, but never for weeks, as at Kilburn. "It is an ill-wind that blows nobody any good," and often when our visitors have passed the exitgates, with much of the upper-crust of the land adhering to them, they have found awaiting them outside a force of enterprising cleansers, ready with straw and buckets of water, to turn an honest penny by relieving them of some of their superfluous weight of earth. Weather productive of such results is a double misfortune to a Society, forasmuch as it not only impoverishes the attendance but involves no small expenditure for timber for temporary crossings and an appalling consumption of straw for live-stock bedding, while many "shocking bad colds" bring grist to the mill of the vet, as well as the family doctor. 


\section{FIFTY YEARS OF A SHOWMAN'S LIFE}

One other weather-vagary is impressed upon the minds of all who deal in show lore, and that is the historic fog which played such havoc with the Smithfield Show in 1873. The "London particular" of the ordinary type is trying enough, especially to those unaccustomed to such visitations, but the one in question was a denser and more virulent compound than usual. It entered into possession of the Agricultural Hall, and held it in a deadly grip. So marked were the sufferings of the poor beasts, accustomed to the pure air of the country-side, and who, being in show condition, were fat and scant of breath, that they were taken at intervals out of their stalls, and paraded up and down the roadway outside, where the atmosphere was a little less oppressive than that within the confined area of the Hall. This afforded a modicum of relief, but not enough to save the lives of some of the animals, who either died forthwith or were slaughtered in order to forestall decease, whilst others more fortunate were dispatched home in hot haste. It was remarked that the sheep and pigs did not suffer to anything like the same extent as the cattle, and it was said that this was due to their having kept their heads in many instances under the straw, which, to a certain extent, filtrated the fog during respiration. If this were so, it is a testimony to ovine and porcine sagacity, but "I hae ma doots," as the explanation sounds a little far-fetched. Men as well as beasts were affected, and had good reason to regret breathing an atmosphere so different to that to which they had been accustomed. Many were laid up from 


\section{THE TRURO TEMPEST}

its effects, and all did not recover, including a good farmer friend of mine, a noted sheep-breeder, whose death was entirely due to the poison he took into his lungs at Smithfield. The monetary loss to exhibitors, owing to the death or illness of their stock, was considerable, but, happily, it stands alone as a sample of what a metropolitan fog can do when so minded.

The Bath and West Society at one time had so bountiful a share of wet weather that, if the crops were suffering from the effects of drought, just previous to the show, it used to be said that there was no need to pray for rain, as it was sure to come as soon as the show opened. However, I do not think that of late years we have been worse off than other Societies in this respect. One of the worst meteorological catastrophes that ever befell us was at Truro in 1913, when as near an approach to an Eastern tornado, as was possible in these climes, visited the show yard, and ravaged it. The entire yard was on high ground, some portions being higher than others, and these had no mercy shown them by the storm. The canvas of the machinery-in-motion sheds was " untimely ripped" from its bearings and torn into shreds. Fortunately, most of the cattle shedding was on lower ground, but some of it did not entirely escape, for a portion of the timberroofing of one of the sheds, weighing several hundredweight, was not only detached from the building, but carried through the air, as though it were a scrap of paper, over two other sheds, and deposited alongside one of them without doing any damage to either man or beast. The 


\section{FIFTY YEARS OF A SHOWMAN'S LIFE}

band made a rapid descent from the bandstand to avoid being blown out of it. The large horticultural pavilion, so long the Society's pride, was rent in twain, and presented a saddening scene of destruction. But just previously its interior was a perfect blaze of beautiful colouring, with the choicest of exotics rising tier above tier, and when the wind had done its worst in double-quick time its contents were little better than a ruinous heap of plants and blossoms.

Most disquieting of all, the gale devoted special attention to rendering the poultry tent uninhabitable. Rows of pens were borne up bodily in the air to the astonishment of their inmates, several of which, taking advantage of pens becoming unfastened, made their escape. Marvellous to relate, all but one were recaptured before nightfall, and the missing one was again safely penned the next day. But, having caught your birds, the difficulty was to discover the particular pen each had occupied, and this was important, because it was the pen and not the bird that bore the identification number. In many cases, where there was a large entry of one breed in a class, it was impossible to know for certain whether the exhibitor of a particular Cochin was Brown, Jones or Robinson. In this emergency, two good judges of poultry were requisitioned, and the escapedbird classes were re-judged. This did not, of course, affect the original judging, but it helped to establish the ownership of some, but not all, of the birds by virtue of their superior merits. In all doubtful cases, an explanatory letter was addressed to the exhibitor, asking him to return 


\section{IVEATHERING A STORM}

the bird if it were not his. There were several such cases, but exhibitors were most prompt in acting upon the request, and every bird ultimately reached its rightful possessor, and we had no case of either loss or damage. It took the secretary's office a fortnight to render everybody content, some birds having made three separate journeys before they reached their proper home.

To anyone acquainted with shows, the most remarkable, as well as the most satisfactory, feature of it all was the celerity and efficiency with which each emergency was dealt with, notwithstanding the suddenness of the call upon the Society's resources. The strain upon the works department in the matter of repairs, etc., was successfully met, and by the following day, the concluding one of the show, the only department which was not in working order and open to the public, was the horticultural, which was wrecked beyond redemption. The general management of a show stands or falls by the way in which it weathers a storm-meteorological or otherwise -suddenly arising and calling for expert and prompt treatment. The Society in this instance stood the test, because every steward responsible for a department not only had the knowledge and experience of what was required to meet an emergency, but, although he had no premonitory warning of what was impending, was at his post ready to deal with whatever arose. With something like a hurricane raging in the midst of some miles of timber erections, housing some thousands of valuable live-stock, and with a great crowd of holiday-folk swarming all over the place, there 


\section{FIFTY YEARS OF A SHOWMAN'S LIFE}

was, by the blessing of Providence, no loss of life or limb, and only two or three very minor casualties, attended to on the spot, were reported. Two or three cattle got loose, but were speedily recaptured. Another gratifying circumstance was the good-temper and consideration shown by everybody, even by those who had suffered inconvenience and loss. It was realized that the situation was due to natural causes, for which no one could be blamed, and that everything possible had been done by those who had any responsibility in the matter.

The gale did not limit its attentions to the show yard, although that being on high ground suffered most. When, at the end of the day, I returned to the Society's headquarters at the hotel, which was on quite a low level, I found the large, old-fashioned casement-window of my bedroom had been blown clean out into the street and deposited in the main thoroughfare. Happily, the good fortune which spared life and limb in the show yard, was operative outside it, for, notwithstanding the street was thronged with visitors, only the casement suffered any injury from the downfall.

Doran has told us that " a good dinner sharpens wit, while it softens the heart," and Stowell, more prosaically, has laid it down that "it lubricates business." Both propositions being so generally admitted, the early disciples of the Bath and West Society, seem to have exercised some self-denial, not very common, either, in those days or in ours, inasmuch as they waited from 1777, when the Society was founded, until 


\section{THE FIRST DINNER}

the year 1785, before they entertained the idea of dining together. However, at the annual meeting, held at the Lower Assembly Rooms, Bath-where the Royal Literary Institution now stands-on December 13 of that year, it was unanimously resolved:

"That it be recommended to the members who may in future attend the annual meetings, that they dine together on those days, it being apprehended that their thus meeting once a year in free and social manner will tend to strengthen the general bond of union, and give opportunity for such a free discussion of agricultural subjects as may prove of general service to the institution. But this meeting is fully of the opinion that the proposal for the Society to be at the expense of such annual dinners, cannot with propriety be admitted."

It will be observed that, with a proper regard for the Society's funds, it was distinctly resolved that those who attended must be prepared to defray the cost of the entertainment out of their own pockets. The Society, having determined to recognize this truly British institution, went a step further in the following November, when it was announced that the first dinner would be held in December, and, in the resolution conveying this, it was intimated that, "as attendance at that meeting, in particular, is a duty incumbent on every member, it is respectfully intreated that none will absent themselves who can with any convenience favour it with their company." The dinner was held at the White Hart Inn-the famous coaching hostel at which Mr. Pickwick put up in later days-on December 12, 1786, 


\section{FIF'IY YEARS OF A SHOWMAN'S LIFE}

where, says the local Press, " an elegant entertainment was provided, to which the Earl of Ailesbury (the President) sent a remarkably fine doe, and the utmost harmony and good humour prevailed." No doubt the assembled company re-echoed Goldsmith's expression of gratitude when he wrote:

"Thanks, my lord, for your venison, for finer or fatter

Ne'er ranged in a forest, or smok'd on a platter."

The success of the initiatory function was sufficient to justify a place being reserved in the Society's programme for many future annual dinners.

The Society has survived many institutions, including the old White Hart Inn, which, in 1867, was demolished, in order to make way for the Grand Pump Room Hotel, the Society's headquarters during the shows at Bath in 1877, 1891 and 1900.

A survival of the annual dinner is to be found in the Council and Stewards' Mess Dinner, which is, and has been for many years, held on a few nights before and during the whole of the show week at the Society's headquarters in the particular town in which the show happens to be held. Here the Society's active spirits foregather, and a very cheery function they make of it. When the fathers, in response to the summons which brooks no denial, have dropped out, the sons have oft-times succeeded to the vacant places, ready and willing to carry on the old traditions in the same blithesome spirit as aforetime. With few exceptions, the members of the Mess are country-side folk, and both branches of the legislature will be found represented at it, 


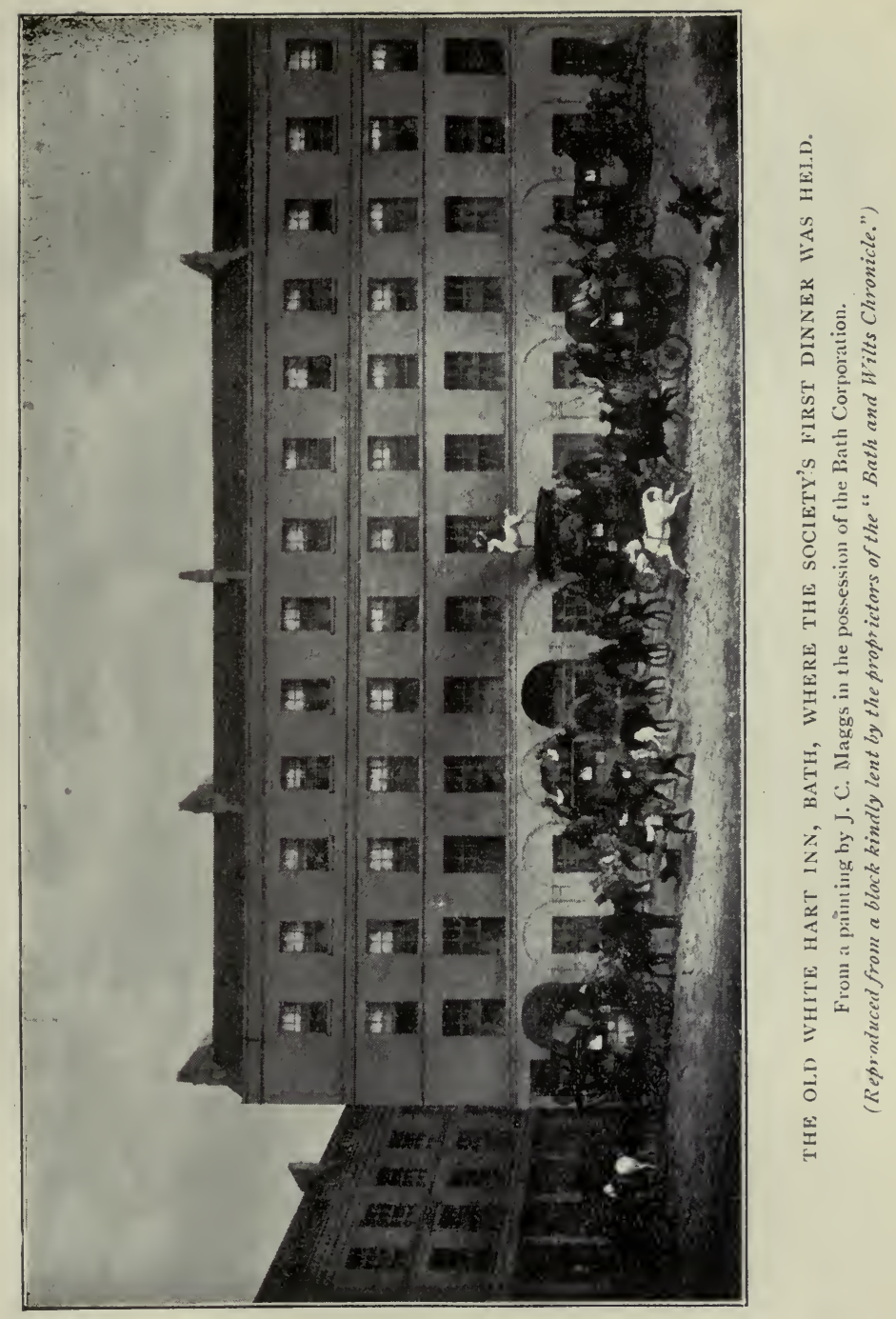



in company with enough of the squirearchy and tenant-farmer element to prevent post-prandial discussions on land problems being too one-sided. The expenses of the Mess are defrayed by the subscriptions of those who are members of it, so that it is no charge upon the Society's funds, and there is always a sufficient balance in hand to allow of an occasional "Mess Wine" night, when no one pays for his liquor. The office of president of the Mess is distinct from that of the Society, and is held for no definite period. There is no formal election to it, but a president is always forthcoming when wanted. One final peculiarity is that the Mess is governed by no written laws, and, there being no record, either official or nonofficial, of its existence, an endeavour was made a few years since to rectify this omission. This resulted in the issue of the following manifesto, signed by the Mess president:

"Ye Olde Bath and West Messe.

"WE whose name and ranke appeareth atte ye foot hereof sende greetynge to alle who owe allegiance toe us bye virtue of our office.

"Whereas, since our accession toe ye style and dignitie of President of ye Bath and West Messe, we have failed to discover any official recordes, sufficientlie settyng forthe ye manneres and, customes of ye honourable fraternitie over whych we have been called upon to presyde, we have felt yt incumbent upon us, for ye guidance of future generations, toe make some provision for ye handing down, intact and in due forme and order, of our ancient traditions. 


\section{FIF'TY YEARS OF A SHOWMAN'S LIFE}

"To this ende, we summoned toe our presence a certayne Bardic Scribe, who hath been soe fortunate as toe enjoye ye societie of ye Messe during noe lesse a period than twentie-eight yeares. As he still retayneth manie of hys faculties, we bade hym give tongue upon ye subject in metrical form and in such spirite of thankfulnesse for ye good companie Providence hath permitted hym to keep as wolde make clear hys indebtedness for ye same. He, having fulfilled our behest with becoming regard for ye principles hithertoe governing our proceedyngs, and with a due sense of ye moralle and material benefits he hath deryved therefrom, yt hath been our good wille and pleasure to enact that ye information so obtained be printed and circulated among our well-beloved and trustie adherents. This hath accordinglie been accomplyshed as follows herewyth, and yt is our fervent hope that yt may enable us and our successors toe definitelie settle, in accordance with well-establyshed precedent, and with due consideration for conflicting claims, such poynts of ritual or etiquette as may hereafter aryse.

" That faire appetytes, good digestyons, and a reasonable liquor-carrying capacitie may ever be ye portion of alle who, in response toe our lawful summons, are faithful particypators in our ancient rites, will ever bee our earnest prayer.

"Given under our hande and seale this seventeenth daye of June, in ye year one thousand, nine hundred and tenne, atte our Court atte in ye Countie of Somerset.

" (Signed)

"President of ye Messe."

278 


\title{
THE SONG OF THE MESS
}

Then followed the metrical record in question, in connection with which it must be explained that the "boxes" mentioned in the seventh verse are the little shanties occupied at night by those devoted stewards who are content, for the better discharge of their duties, to sleep in the show yard instead of at headquarters.

\author{
THE "BATH AND WEST" MESS. \\ A tributary offering. \\ "Dulce est desipere in loco."-Horace. \\ "Tis joyous folly that unbends the mind."
}

"When the Show Yard's at rest and the day's work is done,

There's a halt in the strain and the stress,

For ' dinner is served,' so the message doth run,

Which summons us all to the Mess, to the Mess,

The cheery old 'Bath and West' Mess.

The Chaplain our ancient traditions well knows,

So his grace is commendably brief,

And life seems to all of us couleur de rose

By the time we've worked through to the beef, to the beef,

Through the soup, fish and entree to beef.

At the President's call, having toasted 'The King !'

The night is with happiness crowned,

For then every smoker's permitted full swing,

And the word, 'You can light up,' goes round, all around,

Soon the baccy-olouds circle around.

The problems of life, of the Show, of the day,

We tackle in search of the truth,

And we settle 'em all in a light-hearted way,

As we did in the days of our youth, of our youth,

And with all the cook-sureness of youth.

And the jokelets abound and the ohaff waxes hot,

For a shaft flies from many a bow,

But the arrows by friends and not foes are all shot,

So the victims no pangs undergo, undergo,

'Tis a give-and-take battle, I trow. 


\section{FIFTY YEARS OF A SHOWMAN'S LIFE}

Oh, what stories are told, and how varied the sort!

On the head the right nail oft they hit,

A happy combine with a good class of port,

With a dash of post-prandial wit, a tit-bit,

When spiced by the President's wit.

Ardent spirits who dwell in 'the boxes' at night,

With bated breath tell how they're barred

Of their natural rest long before it gets light,

By the snorer who wakes the whole Yard, the whole Yard,

Every cow, sheep and pig in the Yard.

Should you ask for our rules, we have written ones none ;

Constitutions have always some flaw,

And so we're content, after all's said and done,

With our President's will as our law, as our law;

His nod or his wink is our law.

He sits in the Chair, by no right of descent,

And who can say whence comes the choice ?

He's simply a good thing by Providence sent,

'Accepted with thanks,' and one voice, and one voice,

Both 'Dei' and 'Populi' voice.

Then we'll drink to old friends who in memory live,

I have seen in my time not a few,

But their names are still heard, and a welcome we give

To the sons of the fathers we knew, so well knew,

And who link up the old with the new.

Long life to the Mess! Like a kindly old friend,

My heart it has cheered oftentimes,

I wanted to say so, and that's why I've penned-

Tho' it's but a poor tribute, these rhymes, a few rhymes,

It's my only excuse for these rhymes."

THE WARBLIN' WAGGONER.

There is in the Society's possession an interesting relic of the early days of the Mess, consisting of a fine horned-ram's head, in the brain-pan of which is inserted a silver or plated receptacle for snuff. The head, nose downwards, drops into a metal frame-work on wheels, so that it could 


\section{SOME ANCIENT MEMENTOES}

conveniently make the round of the company in a trundling-tour of the table.

Another memento we have of the festive past is the silken banner of the Society. This was evidently intended to be carried in processions, as there are the cords for attaching it to a pole or poles, and pendent tassels, lead-weighted, to withstand wind-buffetings. I found the old banner, apparently by the world forgot, stowed away amid a miscellaneous assortment of lumber. For sake of old associations I thought it worth rescuing from its dingy surroundings, and being brought into the light of day once more, amid more fitting companionship. So I forthwith had it framed and glazed, and it now occupies an honoured place in the committee room at the Society's offices. It is in goodly company, flanked by the two fine marble busts of the "Agricultural Duke" of Bedford and Sir Charles Hobhouse, by Chantrey and Nollekins respectively, and surrounded by other reminders of the gay old times when one likes to think it headed an annual procession of the members from Hetling House, the headquarters, to a special service at the Abbey. If o' nights these ancient survivors of a shadowy past exchange confidences, I would give something for a verbatim report of their utterances. They can hardly find fault with their haven of rest, with its old-world features-its wainscoted rooms, its antique stairway, broad enough to allow of a free passage to the hoop-petticoats of the Pump Room belles; and with its gracefully-curved landing, whose half-circle facilitated the conveyance right into her room of the lady in her sedan chair. And 


\section{FIF'TY YEARS OF A SHOWMAN'S LIFE}

what notable folk did Pierrepont Street house in those days, with Nelson on one side of the Society's present location and Quin on the other! No doubt, had we only records to prove it, equally good company forgathered in the Society's domicile. Possibly Lady Hamilton may have found her way to Bath at this time, and if so, what would be more likely than her selecting a temporary abiding-place close adjacent to one occupied by him whose name is indissolubly linked with hers? There is a blocked-up doorway in the Society's hall which shows that the houses were at one time connected. If her ladyship's spirit ever visited this sublunary sphere and honoured me with a call at my office, I could show her a MS., with illustrative drawings, in the handwriting of her husband, Sir William Hamilton, who was the contributor of an article to the Society's Journal on an improved method of slaughtering animals for food.

Vain imaginings, such as these, are very harmless, and, at any rate, it adds to the pleasure of working within walls that lend themselves to the conjuring up of visions of a picturesque past, and take one into the realm of fancy; however much may be the disillusionment when the reverie ends. 


\section{CHAPTER XXVI}

Some Personal Happenings-A Double-Barrelled Official-A Vanishing Secretary-A Happy Incident-A Halt on Life's Highway.

$\mathrm{T}^{*}$ the year 1910 the Bath and West Society accepted a very cordial invitation from the 1 City of Bath to hold its Annual Show there
in 1912. In November of 1911 the Bath Corporation had to elect a chief magistrate for the ensuing twelvemonth, and their selection is thus chronicled in the report of the Bath and West Society's Council, presented to the annual general meeting of members in the following May:

"The Council cannot conclude their report without some reference to a very kindly and graceful act on the part of the citizens of Bath, who selected as their Chief Magistrate for the year of the show, and the first year of 'Greater Bath' with its extended boundary, the permanent official representative of the Society. The Council regard this as a very happy indication of the feeling of the city towards the old Society and of the desire of the former to still further cement the friendship so long existing between the two bodies. This has since been emphasized by the cordiality shown in connection with the present exhibition by both the city and its neighbourhood."

On two or three occasions previous I had 283 


\section{FIF'TY YEARS OF A SHOWMAN'S LIFE}

excused myself from undertaking the Mayoralty, but the unique position created by the combination of the two-offices appealed to me too strongly to be resisted. So I accepted the honour designed for me, glad, at any rate, to have an opportunity to offer some return, in the matter of hospitality and in other ways open to a Mayor, for the many kindnesses the old Society had shown me. This is not the place in which to refer to ordinary happenings during my year of office. But I may say that my term had this distinguishing feature, that a few days previous to my entering upon it 20,000 additional souls were, by the enlargement of the municipal boundaries, added to the population over which I had to preside, so that I became the first Mayor of "Greater Bath."

The combination, purely accidental, in one person of two individuals, representing two distinct public bodies whose interests were not always identical, led to many humorous situations of a Gilbertian type. The comedy resulting from such a juxtaposition to be effective must be-as in this case-the genuine outcome of unavoidable circumstances and not the product of artificial adjustment engineered for the sake of effect. In the present instance this necessary condition was observed, inasmuch as the resulting abnormalities in which human nature delights naturally evolved themselves out of ordinary routine and the observance of order and precedent. For instance, as secretary, I had, by direction of the Council, and in accordance with custom, to write and ask myself as Mayor to honour the Society by attending 284 
the show in State with his Corporation in order to perform the ceremony of inauguration. Having approached the Mayor upon the subject, I had then, as Mayor, to inform the City Council of the secretary's communication, and the Corporation, being in full accord with it, requested myself as Mayor to assure the secretary that the Mayor and Corporation accepted the invitation with much pleasure. This the Mayor communicated in a gracious letter to the Secretary, who, in his turn, laid his Worship's letter before the Bath and West Council, and was directed to indite a suitable epistle to the Mayor thanking him for his courtesy in acceding to the desire expressed. From a long schooling in connection with public bodies, where it is not always wise to wear one's heart upon one's sleeve, I was able, when delivering myself of the varied pronouncements from myself to myself, to preserve a gravity of demeanour suitable to the occasion, because, after all, beyond the dual combination there was nothing happening sufficiently out of the normal to bring it within the region of farce-though it was on the borderland of genteel comedy. It must be admitted, however, that others saw in it many opportunities of "innocent merriment" and a gentle play of wits. Both the metropolitan and provincial Press took full advantage of the situation, though in a somewhat irreverent spirit. The Globe even went so far as to describe me as the Pooh Bah of Bath, but made amends by winding up its leaderette upon the subject with the following excellent advertisement of the city: "And now, as in the days of Sheridan, for sparkling and 285 


\section{FIFTY YEARS OF A SHOWMAN'S LIFE}

unforced comedy one must follow the directions often given by our grandfathers - and go to Bath."

In conferring with the Mayor, as the secretary always has to do in relation to the general arrangements, I had frequently to readjust my frame of mind in accordance with what ought to be the views of the particular official I was representing at the moment, because the Mayor naturally desired to obtain as good terms and as many privileges as possible for his fellow-citizens, while the secretary, of course, had to take care not to give his Society away to an undue extent. This resulted in various negotiations between the two representatives, but, both being reasonable, a policy of give and take tided over difficulties by means of fair compromise. I had had, as secretary, a long and varied experience of Mayors, having had to do with a different one annually for, beginning with my young days with the Oxfordshire Society, the space of fifty years. I doubt if there be many about who have had so fine an opportunity as myself of studying Mayors from divers points of view and of appreciating their different manners and customs. At one show, at Truro, I had as many as ten, all in full regalia, on my hands at once, so that what I don't know about Mayors can be hardly worth knowing, and it is astonishing to find how many different types there are when their particular idiosyncrasies are examined in a scientific spirit. Of course, it was quite a novel and educational experience for me to have to regard matters from the Mayoral in contradistinction to the showman or secretarial point of view, and I think has had the effect of 286 


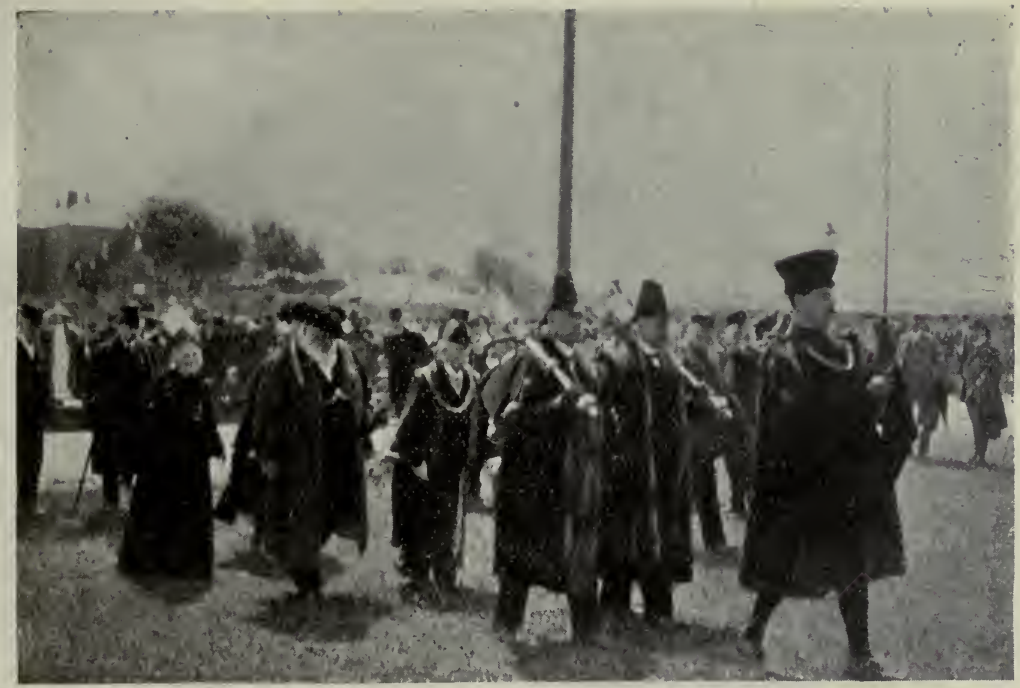

INAUGURATION OF THE BATH SHOW IN I9I2 BY THE, SHOWMANMAYOR, ACCOMPANIED BY THE MAYORESS ANI THE LORD MAYOR OF BRISTOL (SIR FRANK WILLS).

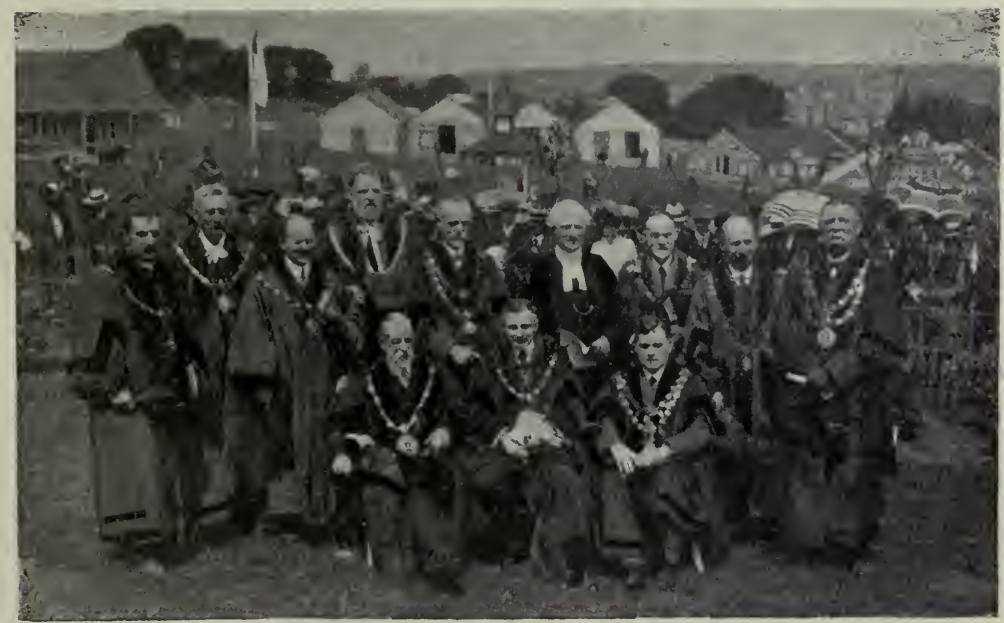

THE IXAUGURATION OF TIIE TRURO SIIOW IN I9Ij

The Mayor of Truro (Mr. W. G. Goodfellow), in the centre of the seatod group, the Town Clerk of Truro and the Mayors of the Cornish Boroughs of Bodmin, Falmouth, Helston, Launceston, Liskeard, Lostwithiel, Penryn, Penzance, St. Ives and Saltash. 



\section{A VANISHING SECRETARY}

rendering me more tender-hearted towards chief magistrates than previously. "A fellow feeling makes us wondrous kind."

If anyone had told me in my young days that any agricultural showman-least of all myself -robed and cock-hatted, would ever have been escorted to his show yard by a Lord Mayor (of Bristol), a bewigged Town Clerk, and the life partner of his joys and sorrows, all disporting themselves in a gorgeous equipage, guarded by mounted myrmidons and preceded by a Tudorattired sword-bearer and divers mace-bearers, I should have counselled his friends to lose no time in settling in which institution for shattered intellects he could be best bestowed. Yet so it fell out.

Every one, from the President of the Society and the Town Clerk downwards, did their best to keep the ball rolling, otherwise the dual-personality jest alive, and the atmosphere of the show yard was dense with japes and jokelets.

The president, in receiving and welcoming the Mayor at the inaugural function in the show yard, began by publicly apologizing for the absence of the secretary, whom, he said, "had vanished into thin air." This gave the Mayor, in his reply, the opportunity of regretting the secretary's absence, and of stating that he had been given to understand that when the Society's Council invited the Mayor to open the show the secretary at once obtained leave to absent himself during that ceremony. His Worship thought it right, in order to remove any misapprehension, to explain that this action on the part of the 


\section{F'IF'Y YEARS OF A SHOWMAN'S LIFE}

secretary was not due to any lack of cordiality between himself and that official, for their relations throughout had been most harmonious, but was owing entirely to physical reasons.

As is customary on such occasions, the Mayor was presented by the president with a bound copy of the Show Catalogue, specially prepared for him by the secretary, and the president accompanied it by a kindly-expressed intimation that he would take the Mayor round the show in order to point out to him the leading features and generally enlighten him with regard to the Society!

In justice to all concerned I cannot omit the concluding item of the ceremony. The Mayor, having formally declared the exhibition open, was about to absent himself in order to exchange the mayoral cocked-hat for the secretarial "topper," when he suddenly found himself trans" formed in all but outward habiliments, into the secretary, and receiving at the hands of the president, on behalf of the Society's Council, a memento of the occasion in the shape of a silver salver as the medium of conveying a message of congratulation and affectionate regard.

The secret of what was intended was, contrary to custom, so well kept that the issue of it took me quite unawares, so that, in making my acknowledgments, I could not forbear reminding his lordship that it was the first time in all these long years that those whom I served had refrained from taking me into their confidence beforehand in all matters connected with the Society. To me, the inestimable value of such a memento lay 


\section{A PHOTOGRAPHIC SOUVENIR}

in the fact that it represented a close and unbroken intimacy of over thirty years without a single rift in the lute. If, as an old writer once said, "the value of a gift lies much in the manner of its bestowal," then the grace accompanying the presentation in this case and the kindliness of the thought that prompted it puts this gift outside the region of any mundane valuation.

It was a happy coincidence that when the Oxfordshire Agricultural Society desired me to have something to remember them by, I received it from the hands of the then Lord Lieutenantthe late Earl of Jersey - of my native county, and when the Bath and West Society, thirty years afterwards, followed suit, the Lord Lieutenant-the Marquess of Bath-of my adopted county was the intermediary.

I possess another souvenir of the occasion, though of an altogether different type, consisting of a photograph. A friend, by means of some ingenious manipulation and a little help from myself, succeeded in producing a very effective piece of photographic portraiture. It represents the Mayor apparently engaged in a delicate negotiation with the Secretary-Showman. The latter is in his official get-up-frock-suit, badge of office, and "topper" all complete-which he is in the habit of assuming when interviewing distinguished personages. Hat in hand, his submissive deportment indicates that he is treating his Worship with all "the deference due to me," as the original Pooh Bah expresses it. The Mayor, on the other hand, cock-hatted, robed and chained, wears an impressive and superior air of 


\section{FIFTY YEARS OF A SHOWMAN'S LIFE}

dignified restraint, expressive of the difficulty he experiences in putting up with the secretary's presence. The picture, apart from its suggestiveness, has a claim to consideration as a psychological study of character. If it survives the advent of Lord Macaulay's New Zealander it will probably be quoted at Historical Societies' Meetings in those far-off days as an irrefutable proof of the baselessness of the tradition which asserted the existence in the year 1912 of a citizen who united in his own person two such distinct individualities as a Mayor and a Showman. The photograph will be successfully appealed to as affording clear evidence of two separate entities, differentiated one from the other by well-defined temperamental characteristics as shown by the play of their respective features.

An incident early in the year 1914 gave me far too much pleasure to allow of its being left unrecorded here. It represented an honour which anyone having any connection with agriculture could not but highly appreciate, whilst the kindly feeling underlying it appealed to me very strongly. It took the shape of a communication to me from the Council of the Royal Agricultural Society of England, stating that, in recognition of my services to agriculture, they had unanimously elected me an honorary life member of the Society. Coming from those to whom agriculture owed so much, and being entirely unexpected, I should be less than mortal did I not greatly value such a compliment, especially as the Bath and West Council were not slow to express their gratification at the bestowal. Its worth was much enhanced by the 


\section{A HALT ON LIFE'S HIGHWAY}

fact that M. Henri Sagnier, the distinguished secretary of the National Agricultural Society of France, was joined with me in its conferment. The artistic qualities of the official document and badge accompanying the communication render them mementoes worthy of being included among those cherished possessions which one likes to feel will survive when the original recipient has laid down for ever his burden of work in this world.

One other recollection, personal though it be, cannot well be omitted if this is to be a faithful record of a showman's experiences. In May, 1915, the Society held its last show for the present, and in September of the same year, as I was plodding along life's highway, I was suddenly arrested in the middle of my stride, and, in terms admitting of no denial, bidden to surrender myself into the hands of the doctors to deal with me as they listed. This, as it meant a long sojourn in a nursing home, entirely deflected for a time the current of my working life. By no merit of my own, but simply because I was greatly blessed by Providence in the matter of health, during my thirty-two years of office with the Bath and West Society, I had not only been at my post throughout every one of the thirty-two shows this period represented, but I had never missed a single Council of the 195 held, nor more than one of the hundreds of committee meetings summoned during the time. It was a sore trial to spoil such a record, but there was no help for it, for my life, if it could be saved, depended upon such success as might attend the taking of immediate action. I had, therefore, sadly to 
FIFTY YEARS OF A SHOWMAN'S LIFE

convey to the October meeting of the Council my inability to be present and the reason why.

Were it not for the sequel there would be little excuse for this mention of a personal-disability. But it is not the lot of every official to serve a governing body capable of transforming a mournful reflection into a sunny memory. Yet it is not too much to say that this represented the answer I received from the Council to my communication; an answer so generous in its terms, so affectionate in its sympathy, that it stirred me to the very depths. It took the form of an illuminated address, signed by every member of the Council available, and accompanying this was a generous presentation represented by "a scrap of paper." The autograph-signatures to the address are an enduring reminder of many old and valued friendships, but, beyond this, the address itself is a treasure to covet for the sake of the artistic beauty of design and colour lavished upon it, and of the skilled eraftsmanship which rendered the shrine enclosing it worthy of its contents. If, as the poet has told us, "a thing of beauty is a joy for ever," its longevity is assured, whilst nothing could exceed the grace and delicacy characterizing the presentation. If anything could add to the worth of such a gift, or to the pleasure of receiving it, it was supplied when it came to me by the hands of Lord Bath, one of the staunchest and most single-minded of friends both of the Society and myself.

This chapter says more than I like about myself, but common gratitude compels me to acknowledge an indebtedness far beyond my powers to repay. 


\section{CHAPTER XXVII}

How I swore Fealty to two Corporations-How Bath helped OxfordThe Juvenility of Oxford compared with Bath.

T HAVE said a good deal about shows for whose direction I was responsible. I have now 1 to tell of a show of a different description in which I took a part.

The combination referred to in the last chapter was not the only dual rôle, which, owing to accidental circumstances, it fell to my lot to play during this, to me, eventful year. It has been my fate at certain periods of my life, to lead a Jekyll and Hyde sort of existence-without, I hope, emulating the villainy of the latter-as will have been observed by those who did me the honour to peruse my record of town-life, In the Days of Victoria. Therein I described the quaint ceremonial which entitled me to rank as a freeman, by birth and parentage, of the ancient and loyal city of Oxford. In open court, in the presence of Mayor and Magistrates, I solemnly bound myself, among other things, to defend the rights and privileges of that city at all hazards whenever called upon by lawful authority to do so. This happened just after I had attained to man's estate, and it never entered then into my imaginings that the time would ever come when, in maturer years; I should solemnly bind myself in the Municipal 


\section{FIFTY YEARS OF A SHOWMAN'S LIFE}

Court of another ancient and loyal city, to undertake on its behalf pretty much what $I$ had already promised to do for the other community. Yet so it was when I was duly sworn in as Mayor of Bath. It was a relief to me to feel-and that accounted for my ease of conscience when I took this second responsibility upon myself-that the relations existing between the two Corporations were of a most harmonious character, because, if either had called upon me to take up arms against the other I should have been in a most awkward predicament, having sworn fealty to both. However, nothing, happily, occurred during my Mayoralty to mar the perfect concord existing between the two bodies. By a singularly fortuitous combination of circumstances, the Oxford Municipality celebrated its Millenary during my term of office as Chief Magistrate of Bath. This resulted in my being honoured with an invitation from the Corporation of my native city to attend the celebration festivities, which I accordingly did in the double capacity of the first citizen of Bath and a Freeman of Oxford. Thus I revisited and in full state the scene of my earliest experiences-and they were many and various, as I have confessed in the volume of old memories just referred toas well as of my first efforts as a showman. Further, I was there, "to my great content," as Pepys would say, as an honoured guest of the corporate body under whose ægis I was born and bred.

There were many interesting and distinguishing features comprised in the ceremonial functions of the day, July 11th, 1912, on which the sun 


\section{THE CIVIC JORDAN}

shone in its fullest splendour, distributing enough of its heat among the wearers of furred robes and cocked-hats to induce a belief that the weather must have been very wintry when our ancestors adopted these habiliments. The main doings consisted of the conferment by the University of an honorary degree upon the Mayor and Town Clerk; a thanksgiving service in the Cathedral; a grand luncheon in the Town Hall; an open-air oration by the Chichele Professor of Modern History; and an historical pageant. This is not the place for descriptive details of these functions, for is it not all writ elsewhere? My aim is-and has been throughout these autobiographical records - to tell of things which neither the historian nor the pressman would probably consider worthy of notice rather than to furnish information to be found in books or newspapers. As it is not chronicled elsewhere, I may state that I devoted all the zeal and devotion of which I was capable, both as a Mayor and as a Freeman, to doing justice to the various entertainments provided.

I need hardly say that I took my Mayoral attendant, Jordan, with me when I set forth on my journey, for he would be a bold Mayor of Bath who ventured far afield without such an escort. As it happened, it was fortunate for all concerned that my trusty guardian accompanied me, for, as it turned out, he played a much more useful and conspicuous a part in the day's doings than I did, and will, I am convinced, be remembered in the University City long after I am clean forgotten. But I will not anticipate-the narrative must run its course. 


\section{FIFTY YEARS OF A SHOWMAN'S LIFE}

Yet, stay! I have to remember that at the present moment I am not unburdening myself to Bath citizens alone, most of whom, especially all of Mayoral rank, know and appreciate our civic sword-bearer's worth, and are aware of what he is to a Chief Magistrate. Those at a distance may need to be told, on the authority of an ex-Mayor, that he is nothing less than the guardian-angel of all holders of the office, ever watchful and vigilant on their behalf, and with an unsurpassable knowledge of Mayoral manners and customs. His profundity of experience enables him to say offhand what occasion calls for full-state, what for semi-state, and what for no-state at all. Without such guidance Mayors would be apt to perpetrate all kinds of enormities, such as disporting themselves in scarlet robes when black were quite good enough, would be adorning their necks with the great gold chain when it was only a collar day; or, maybe, arraying themselves in the red necklet when tradition had ordained that a blue one was the correct wear. Jordan has these and all other such niceties of civic etiquette at his finger ends, and he pilots you through all the shoals and quicksands besetting those strange seas which have to be navigated by the municipal neophyte in so gentle and fatherly a fashion, and yet withal with such assured confidence, that unhesitatingly you place yourself in his hands in the happy consciousness that all will then be well. Add to these mental qualifications physical attributes which, for such a post, could leave nothing further to be desired, and you will then be able the better to understand the happenings at Oxford. 


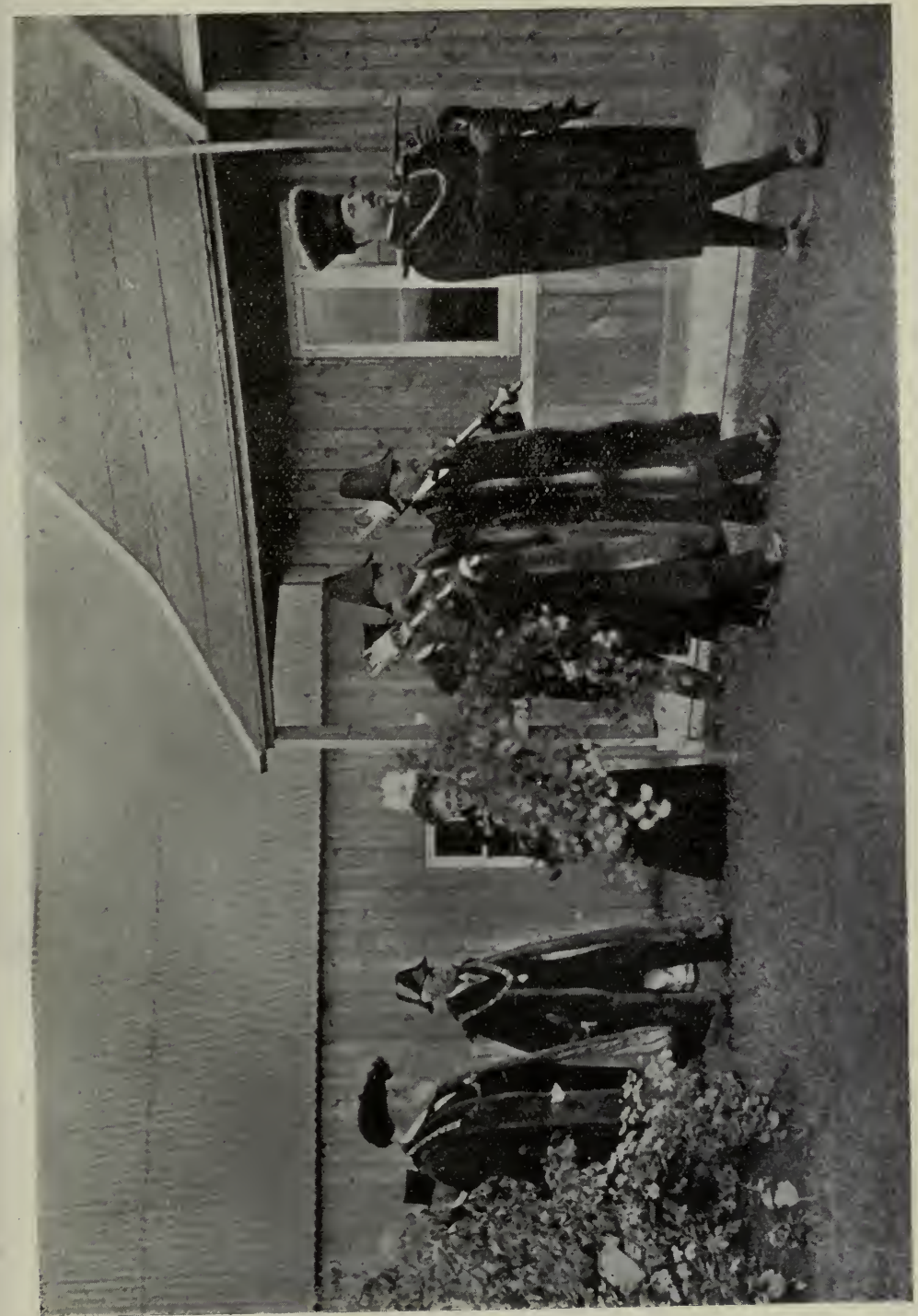

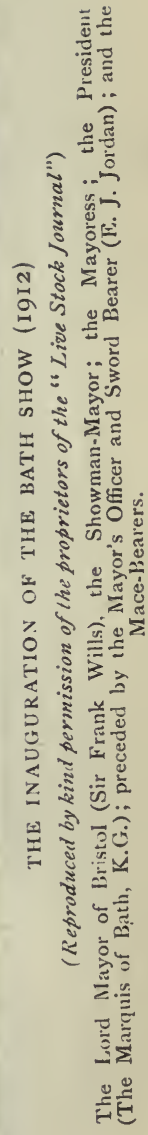





\section{A GATHERING OF NOTABLES}

My trusty henchman and I started for Oxford a day before we were wanted, as I was glad to renew old associations and to give Jordan a little longer opportunity of enjoying much that he would appreciate.

We met the following morning at the Municipal Buildings, where the Mayor received all invited to take part in the celebration. The civic headquarters is a palatial edifice, very up-to-date and ornate in character, and replete with all that the most exacting City Councillor could desire in the matter of luxurious equipment. It is of very modern origin, supplanting what, in the days of my youth, I was accustomed to regard with respectful admiration as a noble structure worthy even of the civic fathers who orated in it. But municipal ideas march with the times, and their exponents are no longer content with such housing as their forerunners thought good enough, and so these richly adorned and expansive-and expensiveembodiments of a decórative age have sprung up all over the kingdom.

We found the Central Hall, its imposing marble staircase and spacious corridors, thronged by a goodly array of notabilities and officials in all their war paint-bishops, deans, M.P.'s, D.D.'s, D.C.L.'s, mayors, heads of houses, etc., not forgetting the Lord Mayor and Sheriffs of London. We were all commingled, and as the robes of some of the higher University degrees rivalled those of the Mayors in brilliancy there was no lack of colour to light up the scene. There was a general buzz of conversation as we waited for some directing power to tell us what to do next. Suddenly 


\section{FIF'TY YEARS OF A SHOWMAN'S LIFE}

a voice which penetrated every corner of the building, and was strangely familiar to me, in stentorian tones too authoritative to be gainsaid, gave utterance to "My lords and gentlemen, will you please take your places in the procession." At the sound of this I, metaphorically, "sat up," not on account of the verbal expression of the utterance, which was just what we were waiting for, but because it instantly transported me back, in imagination, to the Guildhall at Bath. There could not possibly be among the officials at Oxford or anywhere else a second Jordan, and yet that voice, that intonation-but I was not left long in doubt as to who was the owner of that excellent vocal organ, for here was my trusty henchman following up his announcement by actively helping to marshal us in proper order.

I knew Jordan too well to imagine for a moment that he was capable of usurping anyone else's authority, so I was quite easy on that score, and my confidence was justified. As I ascertained afterwards, Jordan, with his capacity for making friends, had established friendly relations with his Oxford brother-in-arms, and, seeing that help was needed, forthwith proffered his services. His Oxford confrère, whose good sense was equal to the other's good nature, was not too proud to accept such an offer, and hence it was that Bath lent a helping hand in the ceremonial observance on an historic occasion of a sister Corporation. That no one's susceptibilities were hurt thereby was amply demonstrated by the fact that the Oxford official took the Bath official to his bosom, and did him the practical and kindly service of 


\section{OLD MEMORIES}

taking him also by the hand and showing him the sights most worth observing in the University City. So all went merry as a marriage bell.

When we had all been sorted out and marshalled in due form and order we moved forward to the Cathedral. What a flood of old memories this let loose ! The Town Hall, whence we started, was next door to the old house, still standing, though with remodelled first floor, where my earlier life was passed and where I first embarked upon a showman's career. We trod with slow and dignified steps the, to me, familiar road adown which day after day I used to hurry, helter-skelter, to the Cathedral School, for in the golden age of youth, when sound in wind and limb, one could afford to run closer to time than I should have cared to have done on that Millenary day, hampered, too, by garments somewhat unsuitable for rapid pedestrianism.

From the street we passed beneath the fine old tower, where dwelleth his resounding mightiness, the great bell, which, until the war, had nightly at nine o'clock sounded its hundred and one warnings that it was time for all well-regulated folk, students especially, to be within doors. As we emerged into Tom Quad and wended our way across it with a solemn dignity befitting the occasion, I saw myself in early youth rushing over that same gravelled road on the way to school, pausing only for a moment to doff my cap to the heir-apparent going home to breakfast after early morning chapel. How astounded I should have been in those days had a seer of the period, bidding me gaze into the crystal, visualized for me 


\section{FIFTY YEARS OF A SHOWMAN'S LIFE}

that gorgeous procession, and pointed out as my future self a grey-headed septuagenarian finely apparelled keeping step with a legal luminaryeither a Recorder or a County Court Judge-in a full-bottomed wig and a Court suit, with whom I was told off to consort.

I lived much of my boyhood over again in that short walk, and pondered over it as I sat in the old Cathedral, which had done much to create in me a love for, and some understanding of, the works of the great masters of church music.

But Father Time waits not for retrospections, and, our thanksgivings and the dean's sermon being ended, we formed up again, two and two, and to the inspiring strains of the Cathedral organ, emerged once more into the brilliant sunlight of Tom Quad. The Cathedral bells did their best to speed the parting guests by their merry pealing, while the city bells in old Carfax tower rang out a joyous welcome to the coming guests as we neared the Town Hall.

Having reached it, I re-discovered Jordan, who, with his customary forethought, had taken steps to ascertain from personal observation that the position in the luncheon hall, assigned to the Mayor of Bath, was such as befitted the representative of that ancient and loyal city. As he himself was perfectly satisfied that the powers-thatbe had made adequate provision in this respect, I knew that the honour of the city had been fully upheld-as it certainly was. My bodyguard, placing himself at my head, having conducted me, fully robed and chained, through the hall to my allotted place, stationed himself behind it with the 


\section{JORDAN'S FATHERLY CARE}

stern determination that, whoever else in that august assemblage perished of hunger, it should not be the Mayor of Bath. To this end, no bearer of either meat or drink was permitted to pass until he had yielded up to Jordan, for my benefit, whatever dish or bottle he was possessed of. And as this was in pre-war days, they were many in number.

Seated next to me was the velvet-sleeved Senior Proctor, a University official, second only in rank to the Vice-Chancellor himself. Notwithstanding, he was supposed to be the stern embodiment of order and discipline, the bête noire of backsliding undergrads, he was so agreeable and interesting conversationalist that I esteemed myself fortunate in being his neighbour. I could see, however, that he suffered from one disability he was not Mayor of Bath, which handicapped him in the matter of rationing. Happily, I was well able to rectify this by requesting Jordan to place him on the same footing as myself, and take the same fatherly care of him as he did of me, and after that we both equally shared in the good things going. These and grace having been disposed of, there was a pause as we waited in expectation of the rising of our host to open the oratorical part of the programme. Instead of which, there came from immediately behind my chair that familiar, full-toned voice, which at once transported me in imagination back to my adopted city, and we were in a moment all brought to attention by the following utterance, delivered with that arresting force which compels attention : "My lords and gentlemen, will you all please face 


\section{FIF'TY YEARS OF A SHOWMAN'S LIFE.}

this way, in order that you may be photographed." Jordan, mindful of his dual capacity, having fulfilled his mission in seeing that I wanted for nothing at the festive board, resumed his other rôle, which fitted him equally well, and gave rise to a general inquiry as to "Who is that fine figure of a man with the powerful voice." I need hardly say that it was with swelling pride that I was able to gratify curiosity.

Jordan was sufficiently helpful in other ways as to ensure a belief that he will be pleasantly remembered in the University-City, and I feel sure that if he lives long enough to see another Oxford Millenary, his presence will certainly be requisitioned by the authorities. I lorought home with me no such undying fame as this, a commemorative silver medal being all I can leave as a memento of the day to those who follow me.

Of course, Oxford prided itself very much on being able to boast of so long an existence, but I was not unmindful of the claims of Bath when it came to a question of longevity. In the vehicle which took me from the Town Hall to New College Gardens, it was my happy lot to be paired with the Chichele Professor of Modern History ' (Mr. C. Oman), who had to deliver in those picturesque grounds the great oration in honour of the Millenary. This gave me a quiet opportunity to assure him that Bath had passed its Millenary long years before it was customary to celebrate such occasions. At the same time, I must admit he made out a good case for Oxford City, on traditional, historical and sentimental grounds, for holding such a delightful function 302 


\section{A RED-LETTER DAY}

as that which had gathered us together. It was a most interesting and scholarly address, appropriately delivered beneath the shadow of the old city walls, forming the boundary on one side of William of Wykeham's foundation, and casting their shadow over the fine old picturesque garden attached to the venerable domicile which housed me and mine during the last stage of my Oxford life. Many then learned for the first time that Alma Mater was of mushroom growth in comparison with the city.

The whole proceedings of the day constituted a show well worth coming a long distance to take part in; and, as there are few things so restful and refreshing to an old showman as a show which he can enjoy free of all responsibility as to its happenings, it goes for the saying that that cloudless July day was one of the reddest of red-letter days of my Mayoral year. 


\section{CHAPTER XXVIII}

The Show in War-Time-Administrative Difficulties-A Concertina and a bit o' baccy-Aid for our Allies.

7 HE Society, inasmuch as it came into being previous to the French Revolution, the

1 revolt of the American Colonies, and the Napoleonic Wars, has lived through more than one crisis in the national history, and has survived more than one social upheaval. Yet its past records during these eventful periods convey that it was but little affected by the momentousness of the times in which it lived. It seemed to have pursued "the noiseless tenor of its way" amid the clash of arms, undisturbed by happenings which were shaping the destinies of Europe and of our Colonies. After a long lapse of years, its tranquil calm was rudely broken in our own time, for it cannot be said that the greatest of wars that has ever desolated the earth has failed to leave its mark upon the old Society.

If not many years ago anyone had told me that I should live to see the day when the holding of agricultural shows would be prohibited by the State on war emergency grounds, I should have put down my informant as a romancer. Yet he would have been a true prophet.

The Bath and West Society, with the concurrence of the State, held on to its show longer 


\section{THE WAR CLOUD}

than many similar associations, conceiving it to be a duty to agriculture to do so until circumstances fully justified its abandonment. The Society's last show took place at Worcester in 1915, and, coming within the war period, was held under certain abnormal conditions. My recollections as a showman would hardly be complete did they not include some particulars of the effect of war's alarms upon the little world embraced by the show yard, and my impressions, should they survive the duration of the war, may help posterity to realize how the social side of agriculture, in kin with every phase of our national life, was coloured and influenced by the abnormal conditions prevailing when nearly all Europe was under arms.

When, in the opening days of August, 1914, the thunderbolt forged by the Kaiser descended upon a peaceful world, the Society was making the necessary arrangements for holding its 1915 show, as previously agreed upon, at Worcester.

The natural and immediate effect of the declaration of war was to distract the attention of the whole country from everything else. The war cloud burst with startling suddenness, for, so unsuspicious had the blessings of peace rendered most of us, that only a comparatively limited few had the prescience to read previous portents aright. When the crash came its effect was overwhelming in a national sense, and every mind was bent upon considering, to the exclusion of every other topic, how the sudden emergency could best be met. Agricultural shows at this moment shared the fate of other institutions 


\section{FIFTY YEARS OF A SHOWMAN'S LIFE}

outside the area of the war, and any thought for them was relegated to a time of less stress and strain in other directions.

In the course of a few weeks it began to be realized that, whether the war was destined to be long or short, there was no immediate danger of the country being defeated by force of arms, or-thanks to the British Fleet-starved into submission. Men's minds then began to be directed to the question as to how far the current of ordinary life should be deflected on account of the war, and those responsible for the conduct of the Society had to consider whether or not, under prevailing circumstances, it was either practicable or desirable to hold a show in 1915. After careful consideration of all the circumstances, the Society's Council resolved that in the best interests of agriculture it was desirable that the 1915 show should be held as previously arranged at Worcester, though this decision was only carried by the casting vote of the chairman at the meeting at which the subject was discussed.

The decision thus arrived at was endorsed by the Board of Agriculture and agriculturists generally, whilst a most gratifying circumstance to all concerned was the support of the show by the King, who made a larger number of entries than he had done at any previous Bath and West Show. They included horses, cattle, and sheep, and were from both the Royal farms at Windsor and Sandringham. In addition to this, a few days before the show opened, his Majesty was graciously pleased to honour the Society by becoming a Life Governor, and causing a cheque 


\section{THE HOLDING OF THE SHOW JUSTIFIED}

for $£ 20$ to be forwarded to the Society in connection with the office.

The show was quite successful as regarded exhibits, and the attendance was in excess of anticipations, bearing in mind that many agriculturists, as well as a large section of the general public, were engaged on military service; that it was held at a time when the mind of the nation was naturally very much preoccupied with other matters; and that the railway companies were unable to provide the usual facilities in the way of excursion trains, etc. Notwithstanding these disabilities, the admission receipts, though, of course, considerably below the average, sufficiently indicated that, although shorn of some of its features, the show could still hold its own with the ordinary sightseer as well as the agriculturist, an attendance of over 24,000 of the paying public on Whit Monday serving to emphasize this. One of the satisfactory results of holding the show was that it convinced those who had been most opposed to this that the right course had been pursued.

So far as the administrative side of the show was concerned, the war undoubtedly gave rise to many anxieties, in addition to those of a financial character arising out of the enhanced cost of material-timber especially-and labour. There were constantly occurring what in old plays used to be described as "alarums," or, in more modern phraseology, "bolts from the blue," creating temporary misgivings as to whether the obstacles thereby created were capable of being surmounted. For instance, not many days before the show 


\section{FIFTY YEARS OF A SHOWMAN'S LIFE}

opened the hay contractor conveyed the startling information that he had been formally served with a notice not to part with hay to anyone but the Government, and so he did not see how, under these circumstances, he could fulfil his contract with us. As every other contractor was in the same boat, the prospect of having several hundred animals on one's hands with no provender for them was something appalling. However, a trustful belief in Providence and in the reasonableness of even a Government Department, when matters were fully explained to the latter, was not misplaced. The military powers that be, as represented by a very courteous official in charge of the district, saw the position we were in, and not only removed the embargo, but, in other ways, facilitated the acquisition of what we wanted. So let this be put down to the credit of the War Office in the days of its disparagement.

The railway companies had made it clear that, with State claims upon them, they could guarantee nothing in the way of delivery. But here also a confidence that such an intimation simply meant that they were going to do their very best to fulfil engagements, but did not want to be landed in a legal liability if, through unexpected pressure in other directions, they failed in the attempt, was justified by the ultimate result, as goods came into the yard with, if anything, more regularity than usual.

Hitherto a sleeper-road to facilitate the transit of the heavy implement traffic through the yard had been regarded as absolutely essential, and steps were taken for its provision as usual, but, 
just before the sleepers were required, Government interposed and commandeered all that were available for military purposes, so we had to dispense with them. Providence, however, once more came to the aid of the Society, and conferred upon it the inestimable boon of the finest of fine weather during the whole period of the show; a blessing only once before vouchsafed to the Society-namely, at Southampton in 1897-within the recollection of the oldest member. True it is that, the week before the show, the rain reduced the implement roadway to the condition of a quagmire, and one traction engine at least was fast bound in it for some time. But a sandy soil, judicious rolling, and brilliant sunshine did much, when once the show opened, to mend matters and save visitors from inconvenience. The foregoing may be regarded as samples of not a few similar difficulties with which the executive had to deal, arising out of an abnormal condition of national affairs. The way out of them was materially smoothed by the readiness with which everybody realized that we were living in no ordinary times, and that allowances must accordingly be made. Consequently, there was no friction, whilst grievances made themselves less manifest than usual.

There was no escape from thoughts of the war in the show yard, for there were too many reminders of its existence, both in the absence of several energetic honorary officials who were serving King and Country, and in the presence, as is the case everywhere now, of many wearers of khaki. 


\section{FIFTY YEARS OF A SHOWMAN'S LIFE}

As the war has progressed, the ranks of the Society's governing body have been still further depleted by the absence of others on active service. Happily, none of these have yet been called upon to make the great sacrifice. But there have been many sad bereavements in the families of those who have sat round the Council table; among the gallant souls who have laid down their lives for the cause being heirs to ancient titles and estates, the hope and pride of their race. Those of the Council, being the majority, over military age have lent efficient aid on Tribunals and in other ways, each man being intent on "doing his bit."

The recruiting sergeants were busy in the show yard in all directions, for the Society offered every facility for this. Those who were told off for this duty were admitted free, and provision was made in the yard for the medical examination of likely candidates for military service. Many placards appealed to all who could to join the ranks of the King's Army, and the officers and men engaged appeared to be well satisfied with the results of their efforts.

A sadder side of the picture was supplied by the many wounded soldiers, who were to be seen on crutches, or with arms in slings, or heads in bandages. The hospitals in and about Worcester in which they were being treated petitioned the Society to grant a reduced charge for their admission to the show. Needless to say, the only possible answer was returned that the Society would be glad to see them free of any charge and to reserve seating accommodation for them on the grand stand and elsewhere. Then 


\section{THE PREVAILING TOPIG}

good-natured outsiders chartered conveyances to bring them to the show, and the number of maimed men who accepted the Society's invitation was a melancholy testimony to the pain and suffering for which the war is responsible.

H.M. Office of Works, too, had a pavilion for interviewing farmers and others with a view to helping them to fill up the gaps in labour caused by absentees on active service, whilst a further reminder of the war was afforded by a display by the Board of Agriculture and Fisheries at their pavilion of a collection of dried vegetables, such as are being sent out to the Expeditionary Forces. In addition, many implement firms showed on their stands exhibits designed to meet war emergencies.

All other topics naturally gave way to that of the war wherever friends met in the yard, for it was difficult to find anyone, from the President downwards, who had not a direct and deep interest in it, owing to their kith and kin having devoted themselves to the national cause.

Very fittingly, the social side of the gathering was relegated to the background, and civic and other festivities were in abeyance. The key-note was struck at the show inauguration, the speakers emphasizing the fact that the show was held as a matter of duty and certainly not as a concession to the pleasure-loving public. As at all other gatherings, the war could no more be kept out of it than could the head of Charles I. be eliminated from Mr. Dick's vocabulary. The Council Mess, though impoverished in numbers, was reasonably cheerful, with the war holding the field as a topic, and the same could be said of the Council and 


\section{FIFTY YEARS OF A SHOWMAN'S LIFE}

annual general meetings held in the yard, for the main subjects of discussion were due to the war.

An instance of the way in which a desire to serve King and Country appeals to the sympathizers of all sorts and conditions of men was given me by a steward, who, by his kindly consideration for the stockmen over a long period, has become very much their friend and confidant. Walking round the cattle-lines, dropping, as was his wont, a cheery word here and there, he came across an old shepherd, who was another regular attendant at the show, in charge of his master's exhibits. After passing "the time o' day," the shepherd asked the steward if he had heard about Bill Burton, who was another regular show attendant. On the steward professing ignorance, his interrogator continued in this wise: "Bill thought he ought to do some fightin' like the rest, and he managed to kid the chaps at the War Office that he was only thirty-five, but, lor' bless yer, he was nearer fifty than that. Howsomever, they took him on, no doubt bein' glad of anybody without bein' too purtickler. So Bill's gone, and now he's in the trenches. He was rather a rough 'un, was Bill, 'tickerly when he'd had a drop, but not bad at 'eart. So me and a few o' my mates thought as we should like to send him somethink that would come in handy to him, just to show as we hadn't forgotten him. So we clubbed together sixpence a-piece and bought him a second-hand concertina and a bit o' baccy. When the Germans ain't worryin' him, he can cheer up hisself and his pals with a tune, and baccy's allus comfortin'." As it did not appear that anyone 


\section{AGRICULTURAL HELP FOR OUR ALLIES}

had previously ascertained whether or not Bill had any knowledge of the musical capabilities of a concertina, or the best means of eliciting them, the amount of delight his performances have afforded his listeners is only a matter of conjecture. No doubt the idea at the back of the mind of Bill's friends could be expressed in the words of Punch, slightly altered:

" And when we march up Potsdam Street, an' goosestep through Berlin, Why, Billy's concertina will play the Army in."

It was a singular conjunction of gifts, but the main point, after all, was the sentiment underlying the action of his old comrades, and this did credit to their hearts.

The devastation wrought by the war was forcibly brought home to the meeting of the Council in the show yard by means of an appeal from a committee initiated by the Royal Agricultural Society of England for the support of a fund to be raised for the purpose of assisting in the restoration of Agriculture in the countries of our Allies, which had been devastated by the war. Contributions in kind, as well as in money, were asked for, and the Council, having previously made known the want to individual members, with satisfactory results, followed this up by a grant of $£ 100$ from the Society to the funds. The subject revived in me some old memories, for in the early 'seventies I had the privilege to be associated with a similar movement, and the ultimate effect of the effort was so remarkable and so fraught with good that it may be worth recalling.

The end of the year 1870 found the Germans as now, in the occupation of a considerable tract 313 


\section{FIFTY YEARS OF A SHOWMAN'S LIFE}

of French territory. The harvest of the small farmers had, therefore, in many parts, never been reaped, and in not a few instances where it had been gathered in, the corn had been commandeered by one or other of the contending forces. Under such circumstances, the peasant farmers were in a pitiable plight. Then it was that the happy thought occurred to the late Mr. James Howard, M.P., that the British farmer might come to the rescue by contributing either money to purchase seeds or the seeds themselves, so that the small farmers might not be entirely stranded. Meetings were called, a good representative committee was formed, and the proposal was enthusiastically taken up by agriculturists generally. Honorary secretaries - of whom I was glad to be one-were appointed in the different districts to assist the scheme and collect donations in money and kind, and, in the end, no less than over $£ 29,000$ in money was contributed, almost entirely by agriculturists, together with large quantities of corn and other seeds. This was supplemented by grants from funds raised in other directions, bringing up the money total, with which the committee had to deal, to over $£ 52,000$. The distribution of the vast quantity of seed represented by this amount was a marvellous piece of organization, the utmost care being taken to ensure that the seeds got into the right hands and where they were most wanted.

This timely action conferred an immense benefit upon thousands of French peasant farmers and their families, and their gratitude was unbounded. It resulted in thousands of acres, 
which otherwise would have remained untilled, bearing abundant crops of oats, barley, potatoes, vetches, maize, etc. The distribution of a large variety of new seeds in the country was, in itself, a lasting benefit, and the superiority of the crops grown from English seed was so marked that the larger proprietors sought to obtain, for future seed-times, a stock from the peasants who had been thus supplied. In fact, it was very remarkable how well the seeds turned out and how completely and adequately the good intentions of the promoters of the scheme were fulfilled. The work of reparation undertaken in 1870 was small indeed in comprrison with that which is now called for, and the claim for help devolving upon us as a nation is far greater than it was then.

Although it is impossible at present to hold another annual show, the Society has maintained its organization intact, and, in addition to carrying out its ordinary work, has formulated and embarked upon a scheme, under which a sum of $£ 200$ has been allocated for the promotion of instruction in milking and for rewarding proficiency in its practice. In accordance with this, grants are being made to such Agricultural Instruction Committees of County Councils within the area of the Society's operations as are prepared to co-operate with the Society in facilitating the objects in question. The scheme has been very favourably received, and it is confidently hoped that it will result in stimulating the supply of good milkers, of which there is a dearth, and in encouraging a proficiency in this important branch of agricultural work. 


\section{CHAPTER XXIX}

Arcadia-"A Shattered Day-Dream."

7 HESE autobiographical reminiscences have necessarily dealt with agriculture and its followers mainly from a practical, in contradistinction to a sentimental, standpoint, but I am minded, before I finally part with my subject, to say something about it in its mythical aspect.

Entirely owing to the imaginative powers of poet and painter, it may be safely averred that no occupation of this life has been so idealized, so steeped in the spirit of romanticism, as the pursuit of agriculture. But those who have invested it with so much charm have invariably sought and found their inspiration in a mythical past such as Kingsley visualized-though he had the future in his mind-when he sang-

\footnotetext{
"When all the world is young, lad, And all the trees are green; " And every goose a swan, lad, And every lass a queen."
}

The jocund nymphs and swains, who, untrammelled by any mundane cares or vicissitudes, tilled the soil and tended the flocks and herds in the perpetual sunshine of Arcadia, lived, moved, and had their being in days to which the memory of man reacheth not. It was certainly long 316. 


\section{AN ENCHANTED LAND}

anterior even to that fabled period, the existence of which is vouched for by such oral tradition as is represented by "I've heered tell" - a declaration often regarded by country-folk as ample evidence of anything and everything, however improbable.

But, although it is not to be expressed in numerals, there cannot be any reasonable doubt as to when Arcadia was in full bloom. Surely it was in-

"That golden age of childhood's sunny prime, That dear, delightful "Once upon a time." "

The moment we attempt any identification later than this, disillusionment sets in and naught remains but "the baseless fabric of a vision."

So I would counsel all young folk, especially, to stave off as long as possible the parting with their birthright-their freehold in the realms of fancy in the "never, never land" of irresponsible nebulousness which leaves everything of any consequence to the imagination. The time comes all too soon when the world of matter of fact claims you for its own; till then wander at your own sweet will in the enchanted land, where one sees visions and dreams dreams. There lies the agricultural world of pastoral simplicity and rural contentment depicted by the poets, where with Phyllis or Daphne, Charyllis or Amaryllis, Sylvia or Chloe, or some one equally companionable-

" 'Mid nature's fairest scenes you'll idly rove, And wander hand in hand through field and grove, White fleecy lambkins will around you skip, And shepherds with their shepherdesses trip In sweet contentment to their daily labour. Or dance in unison to pipe and tabour." 


\section{FIFTY YEARS OF A SHOWMAN'S LIFE}

There the tax-collector never calls, and the sun shines both sides of the hedges. I know, for I lived there once-a-many years ago-long before I became a showman, which was lucky, else I had been far too unsophisticated for the business.

This unpremeditated chapter-the last but one of my story-owes its existence to my happening, when recently turning over some of the literaryor otherwise, according to taste-escapades of my youth, to drop across a piece of versification which, as Touchstone said of his particular Arcadian, is "a poor thing but mine own." It took form on paper not long after I had embarked upon an agricultural showman's career, and oblivion, whence I am now rescuing it, soon after claimed it. It may be said to typify my old love for the idyllic past, tempered by a practical recognition of the prosaic present, and so may help to account for the mental attitude which was the mainspring of my actions during these fifty years of old memories. The references to smock and billy-cock, bonnet and crinoline-all examples of discarded fashions -afford evidence of how long ago it is since these lines were penned.

\section{A SHATTERED DAY-DREAM.}

"Oh, happy were those golden days,

By lyrio poets sung

In madrigals and roundelays,

When all the world was young.

When Damon piped and Phyllis danced,

All garlanded with flowers, And saucy nymphs at Strephon glanced

From 'mong their leafy bowers.

318 


\section{IMAGINATION'S KNELL}

The Damon of the modern type

His Phyllis oft will snub,

And 'stead of playing on a pipe

He smokes one at his pub.

The classio garments worn of old,

His decency would shock,

And wouldn't p'raps stave off the cold

Like corduroys and smook.

He's not in antique sandal shod,

'Twould not exaotly suit

The soil o'er which he has to plod

So well as hob-nailed boot.

No flow'ry fillets grace his brow,

He such displays forswears,

Instead of those adornments, now

A 'billy-cock' he wears.

In bright-hued prints of pattern loud

Our Phyllis now is seen,

And pines till Fortune has endowed

Her with a crinoline.

A crook, with ribbons gay bedeckt,

To use she would disdain,

But takes 'a gingham' to protect

Her bonnet 'gainst the rain.

'Tis pleasant amid nature's charms

To lie in quiet trance,

And tread, whilst locked in slumber's arms,

The fair land of romance,

You're rudely roused, though, from your dream,

Imagination's knell

Is sounded by an engine's soream,

Which quick dissolves the spell." 


\section{GHAPTER XXX}

Some Retrospections-A Sad Feature of Long Service-Direction Posts-Parting Words.

7 HESE later chapters from a showman's life are the embodiment of a longcherished desire to pay tribute, ere I go hence, to the old Society with which I have been so long and so happily connected, by putting on record some account of its work and of its inner life during my lengthened association with it. Opportunity-represented by sufficient leisureto do this came to me owing to the unavoidable suspension of the Society's annual show and also to the necessity, owing to illness, of restricting some of my physical activities.

A cut-and-dried official chronicle of things would not have fulfilled what was in my mind, as it would not have gone beneath the surface or have taken sufficient cognizance of personal characteristics. Besides, it would have been a work of supererogation, inasmuch as a purely official record of the Society's public doings and happenings is to be found in its Annual Journal and elsewhere.

So far as I have been able to ascertain, I have held office, as an Agricultural Showman and Secretary, longer than any of my brothers-inarms now in the land of the living; certainly 


\section{HONORARY WORKERS}

considerably longer than any of the officials of the other leading agricultural associations of the kingdom. Length of tenure, however, is nothing to boast of, but, in my case, much to be thankful for, inasmuch as it has enabled me to play a small part in the promotion of some of the most useful movements of a voluntary character ever brought to bear in this country for the benefit of agriculture. This privilege, and much else, I owe to my connection with a Society having a record of service unsurpassed in its length, or in the good achieved, by any similar body. I have had to restrict my references to such of the Society's work of usefulness as would suffice to illustrate these recollections, but this does not represent a tithe of what has been done by that organization even within the limited space of my own time. For nearly one hundred and fifty years it has been discharging functions of the utmost importance to the wellbeing of the greatest of our national industries.

I have equally had to put limits upon what I should like to say of those who during my own time have rendered yeoman service to the interests entrusted to them. The most I could do was to venture upon a few pen-and-ink sketches to be taken as samples of the bulk, which might help to convey from personal knowledge how much the Society has owed to the energy, the capacity and the disinterestedness of its honorary workers. For obvious reasons, I have selected my examples chiefly from the ranks of those who have crossed the bar rather than of those still living and doing equally good work:

Whatever attractions the Society possessed 321 


\section{FIFTY YEARS OF A SHOWMAN'S LIFE}

for me when I first sought its confidence were increased tenfold after I had had experience of the manner of men with whom I had to do and of the work which devolved upon me, and time has only strengthened the bond between us. This is something to be grateful for beyond expression, and I owe to it that my sojourn in the West has been the happiest period of my life. Now, when, as the Irishman put it, "my future is behind me," I can say this without reserve and without risk of misinterpretation of motive. Did I not do so I should feel that I had omitted from these retrospections a thought that ever holds a predominant place in my mind.

My association with the Bath and West Society has brought me into intimate relationship with many delightful as well as notable personalities, the only melancholy reflection in connection therewith being that death has too frequently intervened when a mutual regard had ripened into a cherished friendship. The Council has ever been a band of brothers, and so the meetings of those admitted within the circle have partaken much of the nature of a family gathering, with the pleasant familiarity and give-and-take spirit characteristic of a harmonious home circle. I have often heard visitors acquainted with other societies who have been guests at the Council Mess comment upon this characteristic as being exceptionally marked, both at the social board and in the show yard. Hence it is that when any member of so united a community joins the majority there is the sadness of feeling that a happy relationship is severed. How often the shadow has been cast 


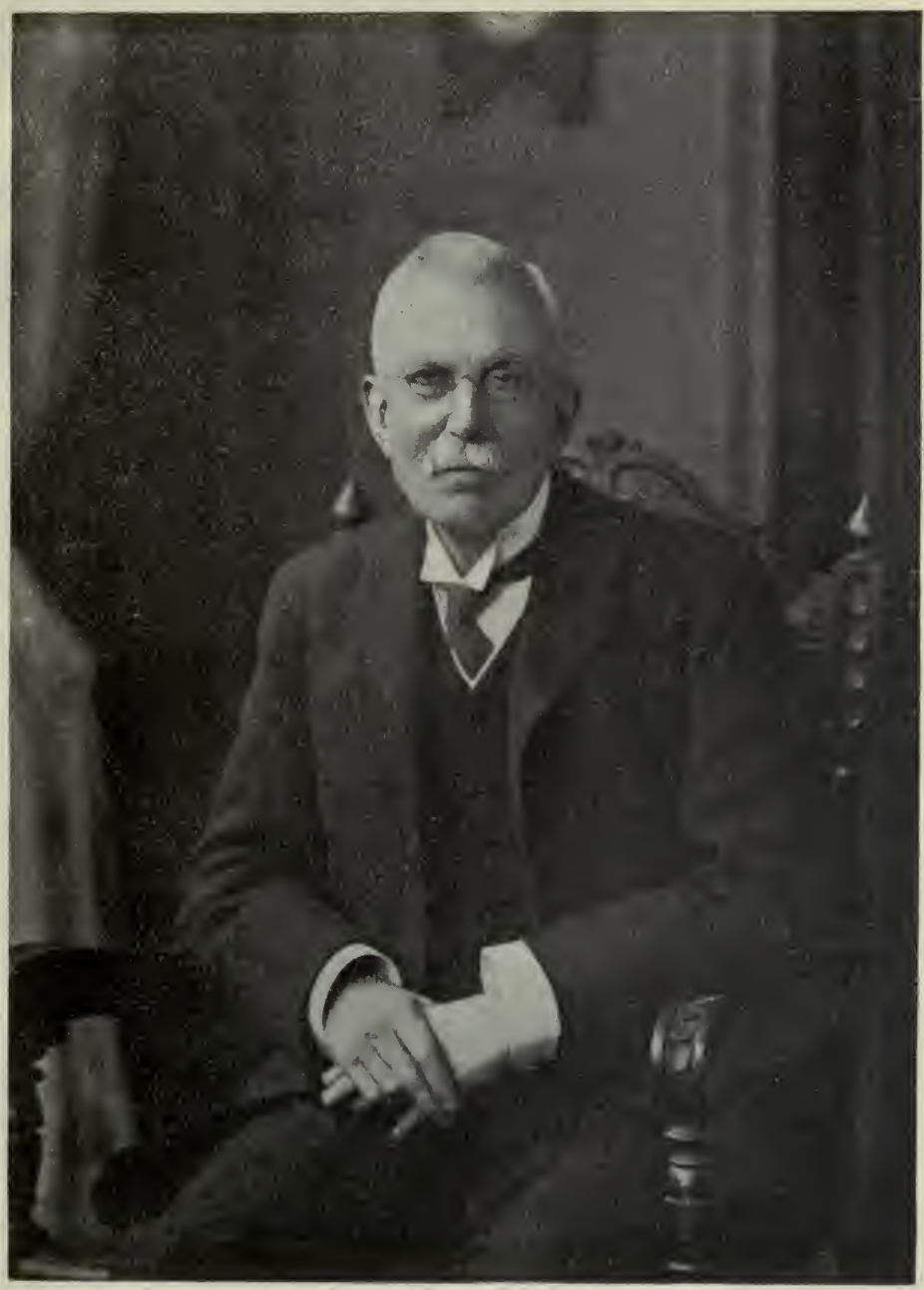

Photo. by THE OLD SHOWMAN, GROWN GREY IN THE SERVICE. 



\section{FORTY YEARS WITHOUT A BREAK}

across my own path can be understood when I say that, of all the goodly number of honorary and permanent show yard and consulting officials who were serving the Society at the time of my appointment, I am the sole survivor still in harness. But, happily, I have not to go beyond the precincts of my own office to find an unbroken link with that ancient past which preceded my own arrival at Bath. As the secretary provides his own office staff, he is unfettered in the selection of it, and when I first set foot, as one having authority, in the Society's offices, I found there on temporary duty pending my arrival a member of the previous secretary's staff, who was there just to "carry on" till the new broom came into action. He was quite a youngster, but I liked his looks sufficiently well to give him the option of staying on long enough to ascertain how we suited each other. This was nearly thirty-six years ago, and Mr. W. A. Smith is still zealously devoting himself to my service, now as my chief clerk, who for many years has been my sheetanchor as well, and the recipient, in an equal degree, of the confidence also of the Society's Council. His time-record, so far as the Society is concerned, throws mine into the shade, for he has forty years to his credit against my thirty-four, and he is still going strong. An association of this standing without a break is something to be very thankful for, especially when it represents such loyal service as in this instance, and I could not close these chapters from my life without acknowledging this.

Having reached the last stage of my gossipings, 


\section{FIFTY YEARS OF A SHOWMAN'S LIFE}

it only remains to gather up a few fragments in the shape of such deductions - if there be any worth preserving - as an old showman's recollections may be supposed to yield. The pleasure, while memory is still able to aid and abet it, of recalling visions of the past, ere they pass out of mind, is a strong incentive to pin them down with pen to paper in the trustful hope that it may not lay one open to the charge of doing nothing better than spoiling good stationery-unpardonable in these days of paper scarcity. But the mere desire to be one's own chronicler is scarcely a sufficiently good reason in itself for adopting the rôle. The incidents of even a very ordinary life may, however, sometimes serve the purpose of directionposts, indicating which roads on the world's highway are likely to be found "good going," which are "rocky," and which lead nowhere.

With this in view, I have endeavoured as far as possible to render my narrative helpful to any interested in the administration of such societies as it has fallen to my lot to be answerable for. As will have been seen from this record of personal experiences, I learnt my business in the first place under the somewhat hard condition of having to serve my apprenticeship at the same time that I had all the responsibilities of a masterman upon my shoulders. Yet I must admit it afforded just the training I most needed, for it called for the exercise of all one's faculties, and cast upon one the onus of finding out everything for oneself - and this represents the most enduring of knowledge-instead of having all things needful in the way of educational equipment laid out 


\section{SOME COMMONPLAGE QUALITIES}

ready to hand for use. Until the hour struck, I was living in a little world of my own, with little room for expansion, and which did not permit of a full utilization of such working capacity as Providence had bestowed upon me.

What I have seen of the world has led me, in my old age, to the conclusion that if the dweller in it acts fair by it and "plays the game," in nine cases out of ten he will have no occasion to rail at its treatment; the conditions being that he runs straight, puts his back into his work, adopts "gentle courtesy" as his key-note, and has, within reasonable limits, the courage of his opinions. With ordinary capacity joined to these negative qualities, which are so commonplace and so easily acquired that no one need be too modest to claim them, the possessor may fairly count upon getting justice done him and a bit over.

In recording one's own experiences and impressions, it is difficult, if it is to be a faithful presentation of events, to avoid occasionally laying oneself open to the charge-as some one has not inaptly put it - of "throwing bouquets to oneself." But it must be remembered that there is no lack of pessimists ready to fling stones rather than bouquets at the world they live in, and if instances of the magnanimity of this terrestrial sphere are to be suppressed by those who have experienced them, the railers have it all their own way and judgment goes by default. If this be not sufficient excuse for expressing gratitude to all and sundry for, whenever needful, helping a lame dog over a stile, I must leave my readers to find a better. 


\section{FIFTY YEARS OF A SHOWMAN'S LIFE}

The world of work-whether it be large or small, official or otherwise-and however safeguarded it may be, must needs have its cares and anxieties, its trials and troubles. These are the common heritage of man, whatever his position, whatever his accomplishments, and are to be regarded as necessities if our probation here on earth is to fulfil its purpose. An ex-Premier, in a finely-conceived address to the youth of an old University, has, in words impossible to surpass in felicity of expression, told us of "the best and most enduring of gifts" that education can bestow upon those engaged in the battle of life, and he sums them up as follows: "The company of great thoughts, the inspiration of great ideals, the example of great achievements, the consolation of great failures." In these days, when so many of the gateways of knowledge formerly bolted and barred are thrown open, the acquisition of what such a galaxy of riches represents is much less difficult than it was in times of yore. "So equipped," said the speaker, "you can face without perturbation the buffets of circumstance, the caprice of fortune, the inscrutable vicissitudes of life." And, though we may not find in such a prescription a panacea for every woe, those who speak from experience will admit that they know of nothing so well calculated to temper life's stress and strain.

It oft-times takes years before events can be viewed in their true perspective, and I cannot look down the avenue of time represented by a fairly prolonged life without a deep feeling of thankfulness for those interventions of Providence 


\section{THE ORDERING OF ONE'S DAYS}

whereby one has been saved from oneself. Then one realizes how much, outside mortal ken, the ordering of one's days has been directed, sometimes in opposition to one's own futile imaginings, to an ultimate end, the wisdom of which time has made plainly manifest. I started in life, as I have told in detail elsewhere, with my mind fixed upon an entirely different objective to that upon which my ambition was ultimately set. Years afterwards I was permitted to understand how my destiny had been shaped in accordance with a pre-ordained end, and for my own good. In saying this, let me make my belief clear-for I am no fatalist-that the individual is far from being a negligible quantity in the shaping of his own life; far from being the mere irresponsible instrument of a Superior Power. His part in the transaction lies in his willingness, or otherwise, to serve when the call is made upon him; to sacrifice, of his own volition, inclination to duty; to do with all his might his allotted task. Having so done, he can possess his soul in patience, and with all good courage await the fulfilment of the promise that "every man shall receive his own reward according to his own labour." 



\section{INDEX}

ABEL, Frère, 163

Acland, Sir Thomas, 143

Administration difficulties, 307

Agricultural Awakening, An, 49

Dinners, 55

Agriculture, The old Board of, 124

Agriculturist, The old, 5

Alcohol in cider, 161

Allington, Lord, 210

All's well that ends well, 115

Althorp, Honest Lord, 193

America, 46

American War, 85

Ancient Mementoes, 281

Apple-tree grafting, 255

Arcadia, 316

Arch, Joseph, 89

Arterial Drainage, 28

Art Union, 251

Assistant Secretary, The, 39

Australia, 85

Balaclata Charge, The, 201

Banbury Agricultural Association, 25

Barker, Prof. B. T. P., 166

Barnum, 4

Bartley, Nehemiah, 254

Bates, Thos., 193

Bath and West Mess, 277

Bath" Field" Club, 140

Society, 47, 59, 98

"I go to, 101

" Marquis of, 107, 289

" Mayor of, 81, 294

"Theatre, The, 7

Bedford, Duke of, 281

Bemister, Sam, 54

Benjamin Franklin relic, 185
Berkeley Castle, 97

Earl of, 254

Best, Capt. Hon. J. C., 204

Bicester, 40

Billingsley, John, 259

Bishop and the Boy, The, 171

Blenheim Park, 68

Bodleian Library, 21

Bold Stroke, A, 35

Booming a Show, 36

Booth, T. C., 96

Boscawen, Hon. and Rev. J. T., 204,222

Brandy and Baccy, 29

Brasenose, 12

Bridgwater, 111

Bristol, 81

" Lord Mayor of, 83

British Farmer, The, 6

Brodrick, Hon. J., 70

Brown, Prof. Sir G. T., 85, 125

W. J., 131

Bruce, Mr., 96

Buccleuch, Duke of, 96

Butleigh Revel, 76

" The Squire of, 155

CALTHORNIA, 85

Cardwell, Viscount, 53

Carfax, 78

Carruthers, Prof. W., 125

Carving simplified, 54

Cattle Plague, The, 85

Central Chamber of Agriculture, 47

Chamber of Commerce, 83

Chantry, 249

Chaplin, Mr., 211

Cheap Repast, A, 53 


\section{INDEX}

Cheese, An Archdeacon on, 221

$\Rightarrow \quad$ taints, 129

"The Song of the, 231

Cheston, R. B., 257

Christ Church Cathedral School, 9

Christmas dinners, 51

Churchill, Lord Randolph, 68

Cider, Alcohol in, 161 " making at home and abroad, 152

Clarendon, Lord, 211

Cloud and Sunshine, 268

Clutterbuck, Rev. C., 28

Craigie, Major, 177

Coke of Norfolk, 181

Colman's "John Bull," 7

Connaught, Duke and Duchess of, 218

Contempt of Court, 11

Continental Powers, 50

Continuity of interest, 107

Cooke, C. W. Radcliffe, M.P., 156,257

Cork, Earl of, 106

Crimean War, 85

Cumner, 9

DAIRY Education, 123

Daubeny, Dr., 176

Day-dream, A shattered, 318

Denison, Archdeacon, 220

Denmark, Prince Charles of, 211

Derby Day, 201

" Lord, 66

Devonshire, Duke of, 94

Dickens, Charles, 7

Diner à la Russe, 52

Divining Rod, The, 131

Double-barrelled Official, A, 284

"Dowser's " Letter, A, 141

Draw, A lucky, 252

Drink, A Royal, 13

Druce, Joseph, 46

" Milton, 46

" Samuel, 46

Dual Rôle, A, 293

Duckham, Tom, 86

Duckworth, Sir John, 100

Dundreary, Lord, 113

Dunmore, Lord, 97
EddCation,'Model Schemes of, 163

Election, An old-time, 261

English Agricultural Society, 94

Epistolary Singularities, 265

Evening's Diversion, An, 62

Edward VII., King, 13, 206, 226, 249

FALCONER, Wm., 259

False Prophet, A, 251

Farmers' Club, 27, 47, 177

" Defender, The, 91

" Trials, 89

Farriery Schools, 245

Father's Custom, It was my, 61

Festive Side of Agriculture, 51

Flight of Time, The, 81

Fielding, Hen., 7

"Fine old English Gentleman," 66

Fitzhardinge, Lord, 97, 229

Franklin, Benjamin, 184

"Freeland," 46

French Courtesy, 165

Fruit grafting, 257

Future of Shows, The, 49

GaRNe, G., 46

" T., 46

"Gee-up, Dobbin," 176

General election, 70

George V., King, 81, 199

George, Lloyd, 26

Gentleman, An honest, 207

Gibbons, George, 220, 224

Gilbey, Sir Walter, 177

Gillett, C., 46

, G., 46

Goldsmith's Deserted Village, 77

Good men and true, 47

Goodwin, Josiah, 178

Gray, Jonathan, 203

Gunter, Captain, 97

HAMILTON, LADY, 282

" Sir Wm., 282

Hammersley, Hugh, 26

Harcourt, Sir Wm., 53, 87

Harris, Joseph, of Woodperry, 12

Hartley, David, 186

Headington, 74 
Henley, Joseph Warner, 66

History repeating itself, $8 \mathrm{I}$

Hobbs, W., 46

Hobhouse, Sir Benjamin, 259

Honest Lord Althorp, 193

Horizon, A clouded, 85

Horse Box, A Missing, 113

Horse Shoeing, 244

Howard, Chas., 46 James, M.P., 177, 314

Hunting at Oxford, 8

" Souvenir, A, 16

ILCHESTER, Lord, 209

Imagination's Knell, 319

"JEAMES," A reproving, 247

Jenkins, H. M., 95, 177

"Vaughan, 136

Jersey, Earl of, 104, 177

Joke, A standing, 83

Jordan, the Mayor's Attendant, 83, 295

Jorrocks, Mr., 7

Journal, The Annual, 179

Jubilee, A Showman's, 3

KEPPEL, Colonel, 18

Key to Success, The, 33

Kilburn Slough, The, 269

Kindly Send off, A, 104

" Thoughtfulness, 211

Knight, T. A., 257

LABOURERS' Revolt, The, 89

Land, An enchanted, 317

Lansdowne, Marquis of, 7, 211

Latham, T., 46

"Lawyer, H.," 17

Lemonade and Gin, 62

Lennard, Sir John, 149

Letter, An historic, 185

Letter-bag, A Showman's, 263

Lipscomb, Dr., 237

Life Guards Band, 43

Life's Highway, A halt on, 291 , Sign Posts, 309

Links with the New World, 183

Linwood, 9

Llandaff, Bishop of, 170
Lloyd, F. J., 125, 155

London, Lord Mayor of, 245

Long, Walter, 211

"Wittenham, 28

Loyal service, 323

Luttrell, G. F., 194

, Col. H. A. F., 194

Maliganed landowners, The, 93

McIntosh, Mr., 96

Magdalen Bridge, 16

, College, 12

Making headway, 41

Malt Tax, Lord Redesdale on, 191

Market merry, 56

Marlborough family, 68

Marsham, Dr., 18

Mason, Jas., 95

Matthews, Sir A. H. H., 48

" A. T., 46

William, 183, 259

Maud, Princess, 211

Melhuish, Sam, 248

Merton College, 18

Mess, Bath and West, 277

Methods of divining, 135

Microbe, The Mysterious, 130

Milking Competitions, 47

Milton Druce, 47

Mixed Drinks, 55

Morrell, G. H., 102

Morris dancing, 74

Morton's " Speed the Plough," 7

Müller, Max, 221

Mullins, John, 131

Murch, Sir Jerom, 181

Mutual arrangement, A, 56

NAPOLEONIC Wars, 66

National Fruit and Cider Institute, 166

Nelson, Lord, 282

Neville Grenville, R., 77, 155

Newport (Mon.), 59

New Year's Day, 52

Notables, A gathering of, 297

Oud Memories, 299

" order changeth, The, 5

"Stager, The, 15

Oman, C., 302 


\section{INDEX}

Ormerod, Miss Eleanor, 233

Oxford, 35

Miss Georgina, 236

, City Public Library, 21

" Corn Exchange, 22

" Down Sheep, 46

"Freeman of, 294

, as a Hunting Centre, 8

" Municipality Millenary, 294

Oxfordshire Agricultural Society, 21

Prince of Wales, 13, 18, 228

Paget, Sir Richard, 147

Past-masters of Chairmanship, 205

Peer and the Muck Cart, The, 243

Pell, Albert, 86

Personal happenings, 283

Philadelphia, 46

Pickwick, Mr., 275

Plowman, Joseph, 176

Political Strategy, 37

Visitor, A, 71

Pooh Bah of Bath, 285

Pony, A Volatile, 217

Popular attractions, 45

Practical Committee, A, 46

Prime Minister, The, 36

Progressive Society, A, 120

Pusey, Dr., 222

Quenn, H.M. The, 81, 228

"Alexandra, 210

"Victoria, 78, 226

RACK, EdMUND, 181

Radnor, Lord, 59

Ram, A celebrated, 46

Read, C. Sewell, 86, 177

Redesdale, Earl of, 189

Reid, Sir Geo., 83

Relics of the Past, 185

Rest, A Haven of, 63

Retrospections, 305

Rew, Sir R. H., 46, 102

Royal Agricultural Society, 44, 94, 290

, Show in 1840,227

Royalty and Labour, 215
Royalty impounded, 19

, in the Show Yard, 206

A Wedding Gift to, 229

Russia, 52, 85

Sagnier, M. Henri, 291

St. Brieuc, 158

Saints' Days, 9

Salisbury, Marquis of, 211

Sanger, Lord George, 4

Scientific theories, 137

Scott, Sir Walter, 32

Seeing is believing, 65

Setting the fashion, 127

Shandy, Tristram, 118

Sharp, Cecil, 59

Shoeing competitions, 47

Shorthorn boom, 97

Showman's Jubilee, A, 3

Show, A War-time, 306

, in War-time, The, 304

" preliminaries, 23

, Yard incidents, 240

", recruiting, 310

Side Shows, 249

Signs and omens discredited, 119

Silence is golden, $\mathbf{5 7}$

Sinclair, Sir John, 124

Smithfield Club, 47

Smith, W. A., 323

Fog, The, 270

Smollett, 7

Somerville, A. F., 141

" Lord, 255

Some equine mischances, 213

Some Good Samaritans, 169

Song of the Messe, 278

Souvenir, A photographic, 289

A cherry-stone, 218

Speech and Song, 58

Speed the plough, 7

Spencer, Earl, 94

Sport, A bit of, 42

, A good old, 12

Standing joke, a, 83

Steward, A kindly hearted, 173

Stop Thief, 79

Story of a Watch, 80

Street, Geo., 46

Superstitions, 117 


\section{INDEX}

Supplementary Attractions, 44 Surprise packet, A, 253

$$
\text { " visit, A, } 71
$$

System $v$. Rule of Thumb, 125

Stow-wood, 9

TAKE care of the Butter, 267

Thame, 33

" Show, 39

Thames floods, 28

Thomson of Culham, 31

"William, 30

Thorntion, John, 98

Thorold, Dr., 223

Towneley, Col., 96

Trafford, William, 74

Tragedy, Next Door to a, 111

Travelling Missioners, 126

Travers, Mr., 255

Tread well, John, 46, 177

Tredegar, Lord, 198

Truro Tempest, The, 271

UNDERGROUND Railway, 75

VANISHING Secretary, The, 287

Varied drinks, 55
Vaslet, Lewis, 183

View halloo, A, 15

Victoria, Princess, 211

Vocal harmony, 58

Voelcker, Dr. J. A., 125

Voyage of Discovery, A, 156 ,

WaLes, Prince and Princess of, 228

Waiter, An enterprising, 218

War Reminiscences, 303

War-time Show, 306

Watch, Story of a, 80

Water divining, 133

Weathering a Storm, 273

Weymouth, Viscount, 107

Wiltshire, 60

Witney Show, 42

Won by a neck, 103

Wonderful Woman, A, 233

Woodford, Mr., 261

Woodstock Show, 18

Working of the Spell, 40

Worry not work that kills, 109

Wynford, Lord, 172, 245

Y.M.C.A., The, 175

Young, Arthur, 179 


\section{BY THE SAME AUTHOR}

\section{In the Days of Victoria}

SOME MEMORIES OF THINGS AND MEN

With numerous Illustrations. $\quad$ 10s. $6 d$. net.

\section{SOME PRESS OPINIONS}

"It is a considered, connected, admirably written book, the philosophy and observation of a lifetime. A lively and informing picture of Victorian times."-Daily Chronicle.

"Constantly alive to the great opportunities thus afforded him of seeing notable men and taking part in notable events, Mr. Plowman has reaped his reward in a life of singular and most diversified interest."-Evening Standard.

"We must be grateful for a volume of conversation that calls up past times so genially and so tolerantly."-Daily News.

"Mr. Plowman's opportunities were so unusual, and he can call up the past so well, that his autobiography resolves itself into a most felicitous picture of Early Victorian and Mid-Victorian times."-Sunday Times.

"This excellent book, so reminiscent of vanished sights and faces, of cheerful playhouses long since pulled down, and of fashions gone hopelessly out of date-all described with vivacity and honest pleasure."

-Rt. Hon. Augustine Birrell in the Nation.

"I cordially recommend this pleasant and good-humoured book to the attention of readers."

-Claudius Clear in the British Weekly.

"Books of well-told reminiscences are peculiarly welcome in these days, and hearty greetings will be accorded to this volume."-Land and Water.

JOHN LANE, THE BODLEY HEAD, VIGO STREET, W. I 

UNIVERSITY OF CALIFORNIA LIBRARY, BERKELEY

THIS BOOK IS DUE ON THE LAST DATE STAMPED BELOW

Books not returned on time are subject to a fine of $50 \mathrm{c}$ per volume after the third day overdue, increasing to $\$ 1.00$ per volume after the sixth day. Books not in demand may be renewed if application is made before expiration of loan period.

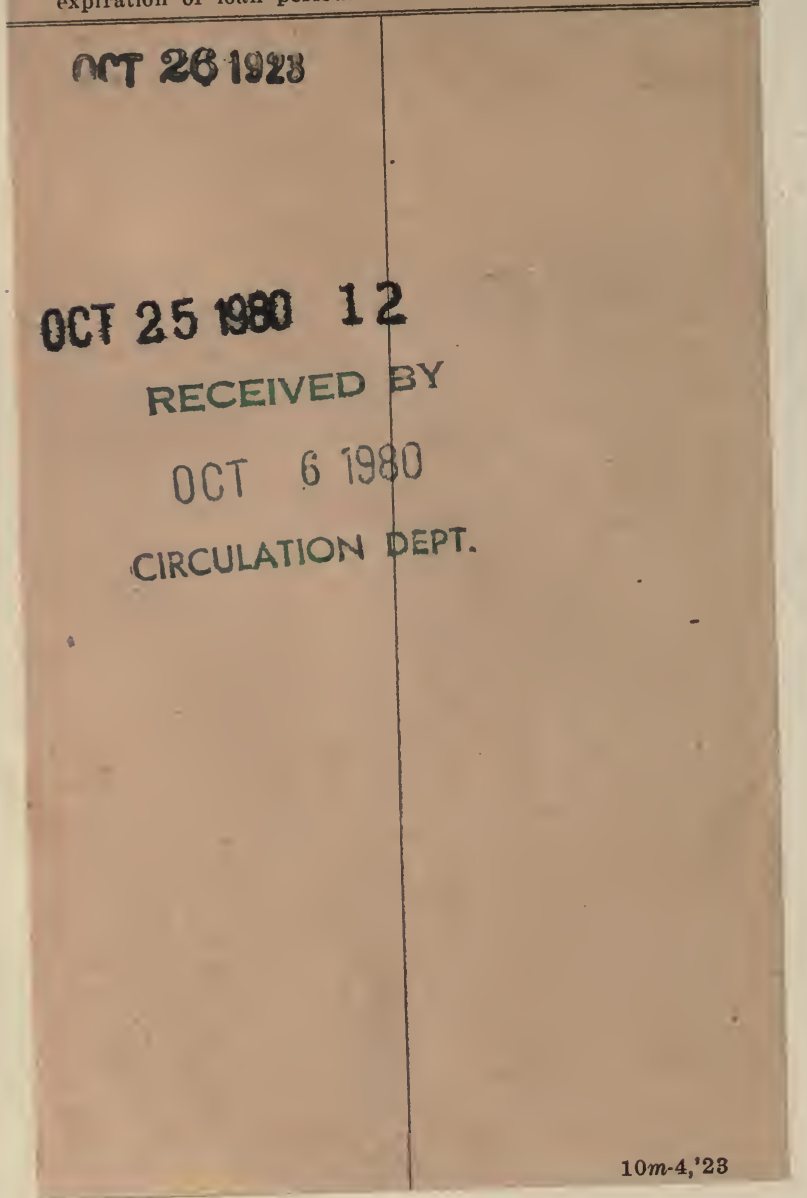



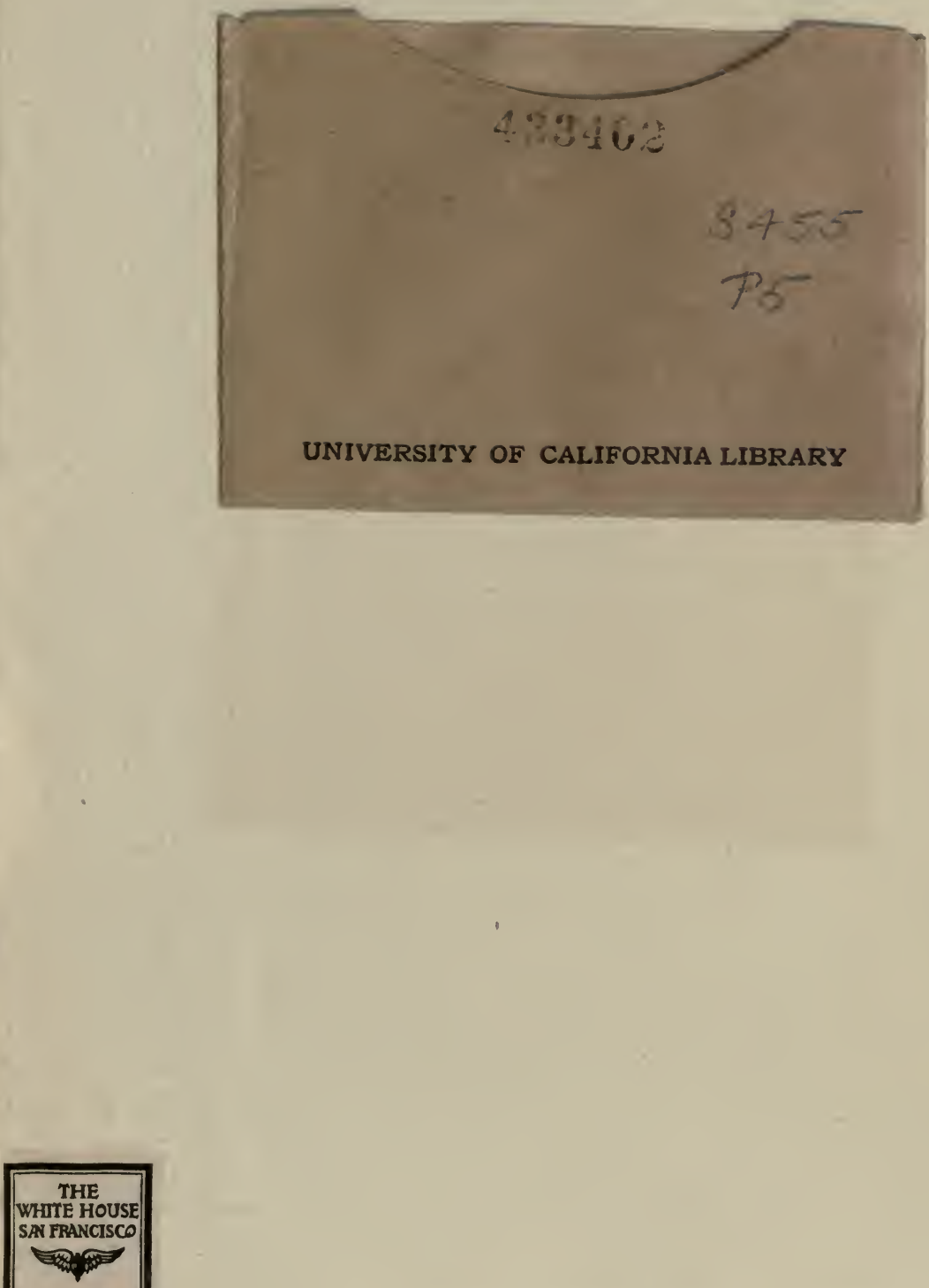
